DEPARTMENT OF THE INTERIOR

$$
\begin{gathered}
\text { W. SHERMAN, } \\
\text { Civil Engineer, } \\
\text { Belmont, Mass. }
\end{gathered}
$$

AN I

\title{
IRRIGATION PAPERS
}

OF THE

UNITED STATES GEOLOGICAL SURVEY

. No. 48 .

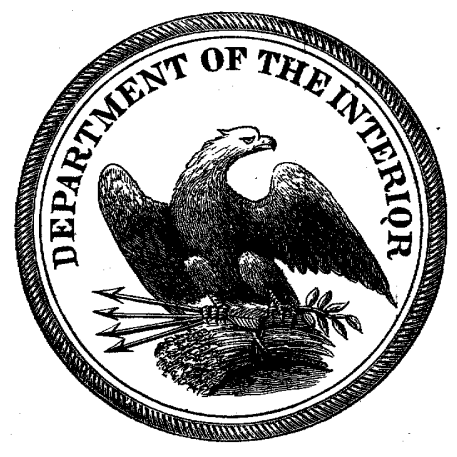

WASHINGTON

GOVERNMENT PRINTING OFFICE

1901 



\title{
UNITED STATES GEOLOGICAI SURVEY
}

CHARLES D. WALCOTT, DIRECTOR

\section{OPERATIONS AT RIVER STATIONS, 1900}

\author{
A REPORT OF THE
}

\section{DIVISION OF HYDROGRAPHY}

OF THE

\section{UNITED STATES GEOLOGICAL SURVEY}

\author{
PAR'T II
}

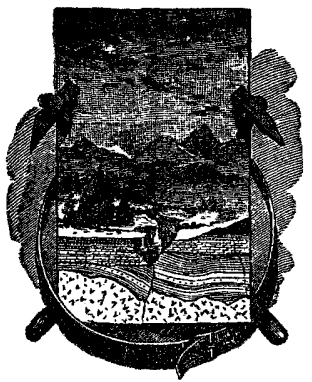

WASHINGTON

GOVERNMENT PRINTING OFFICE

1901 



\section{CONTENTS.}

Measurements at river stations........ 107

Wissahickon Creek near Philadelphia, Pennsylvania................. 107

Schnylkill River above Philadelphia, Pennsylvania ................... 109

$\begin{array}{ll}\text { North Branch of Susquehanna River at Wilkesbarre, Pennsylvania .... } & 110\end{array}$

North Branch of Susquehanna River at Danville, Pennsylvania .. . . ... . 111

West Branch of Susquehanna River at Allenwood, Pennsylvania ..... 111

Juniata River at Newport, Pennsylvania . . . ...................... 112

Susquehanna River at Harrisburg. Penusylvania ................... 113

Miscellaneous discharge measurements in Pennsylvania . ............ 114

Patapsco River at Woodstock, Maryland ......................... 115

North Branch of Potomac River at Piedmont, West Virginia ....... . . . 115

South Branch of Potomac River near Springfield, West Virginia..... 116

Antietam Creek near Sharpsburg, Maryland ....................... 117

North and South rivers at Port Republic, Virginia ................... 118

North Branch of Shenandoah River near Riverton, Virginia. . . . . . ... 118

South Branch of Shenandoah River at Front Royal, Virginia . . . . . . ... 119

Shenandoah River at Millville, West Virginia . . . . . . . . . . . . . . . . . 120

Potomac River at Point of Rocks, Maryland...................... 121

Monocacy River near Frederick, Maryland ..... . . . . . . . . . .

Rock Creek at Zoological Park, District of Columbia ............... 125

Appomattox River at Mattoax, Virginia . . . ...................... 126

North (of James) River at Glasgow, Virginia . . . . . . . . . . . . . . ... 127

James River at Buchanan, Virginia........................... 128

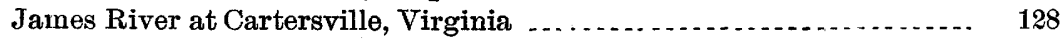

James River at Holcomb Rock, Virginia.......................... 129

Roanoke River at Roanoke, Virginia ............................ 130

Roanoke River at Neal, North Carolina ........................ 131

Dan River at South Boston, Virginia.......................... 132

Staunton River at Randolph, Virginia . . . . . . . . . . . . . . . . . . . . . 133

Tar River at Tarboro, North Carolina. ... . . . . . . . . . . . . . . . . . . . 134

Neuse River at Selma, North Carolina .... . . . . . . . . . . . . . . . . 135

Deep River at Cumnock, North Carolina............................. 136

Cape Fear River at Fayetteville, North Carolina ................. 137

Yadkin River at Siloam, North Carolina .......................... 138

Yadkin River at Salisbury, North Carolina. . . . . . . . . . . . . ....... 139

Yadkin River at Norwood, North Carolina .......................... 140

Catawba River near Morganton, North Carolina ..................... 140

Linville River near Bridgewater, North Carolina .................... 142

John River near Morganton, North Carolina ....................... 142

Catawba River at Catawba, North Carolina....................... 143

Catawba River at Rockhill, South Carolina........................ 144

Broad River (of the Carolinas) at Dellinger, South Carolina. . . . . . . . 145

Broad River (of the Carolinas) near Alston, South Carolina . . . . . . ... 146

Saluda River at Waterloo, South Carolina ....................... 147

Tallulah River at Tallulah Falls, Georgia ......................... 148

Tugaloo River near Madison, South Carolina....................... 149 
Measurements at river stations-Continued.

Savannah River near Calhoun Falls, South Carolina ................. 149

Savannah River at Augusta, Georgia ......................... 150

Broad River (of Georgia) near Carlton, Georgia .................. 151

Oconee River near Dublin, Georgia . . . . . . . . . . . . . . . . . . . . . . . 152

Yellow River at Almon, Georgia .................................. 153

Towaliga River near Juliette, Georgia .......................... . 154

Ocmulgee River at Macon, Georgia. .............................. 155

Flint River at Albany, Georgia . . . . . . . . . . . . . . . . . . . . . . . . 156

Flint River.at Woodbury, Georgia .............................. 157

Chattahoochee River at Oakdale, Georgia . . ... . . . . . . . . . . . . . ... 158

Chattahoochee River at West Point, Georgia. . . . . . . . . . . . . . . . . . 159

Etowah River at Canton, Georgia $\ldots \ldots \ldots \ldots$

Coosawattee River at Carters, Georgia ............................. 161

Oostanaula River at Resaca, Georgia ....................... . . ..... 162

Coosa River at Rome, Georgia ........

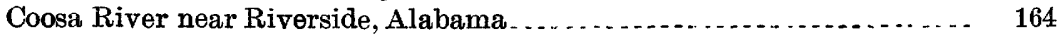

Coosa River at Locks Nos. 4 and 5, Alabama . . . . . . . . . . . . . . . . . . . . ... 165

Tallapoosa River near Susanna, Alabama ......................... 166

Tallapoosa River near Sturdevant, Alabama . ...................... 167

Tallapoosa River near Milstead, Alabama ......................... 168

Alabama River at Montgomery, Alabama ......................... 168

Alabama River at Selma, Alabama .............................. 169

Black Warrior River at Tuscaloosa, Alabama ................... 170

Black Warrior River near Cordova, Alabama ...................... 171

Hillabee Creek near Alexander City, Alabama . .................... 172

Talladega Creek at Nottingham, Alabama ....................... 173

Big Sandy Creek near Dadeville, Alabama . . . . . . . . . . . . . . . . . . . . $\quad 174$

Tombigbee River at Columbus, Mississippi ........................ 174

Tombigbee River near Epes, Alabama _... . . . . . . . . . . . . . . . . 175

Youghiogheny River at Friendsville, Maryland ..................... 176

Cheat River near Uneva, West Virginia . . . . . . . . . . . . . . . . . . . . . . 177

New River at Radford, Virginia ............................... 178

Greenbrier River at Alderson, West Virginia ..................... 178

North Fork of New River at Weaversford, North Carolina ............ 179

South Fork of New River at New River, North Carolina. . . . . . . . . . . 180

New River near Oldtown, Virginia . . . . . . . . . . . . . . . . . . . . . . . 181

New River at Fayette, West Virginia _.......................... 181

South Fork of Holston River at Bluff City, Tennessee ................ 182

Watauga River at Butler, Tennessee ............................... 183

Roan Creek at Butler, Tennessee . . . . . . . . . . . . . . .

Elk Creek at Lineback, Tennessee . ... . . . . . . .

Nolichucky River near Chucky Valley, Tennessee . . . . . . . . . . . . . . . 185

French Broad River near Asheville, North Carolina ................. 186

French Broad River at Oldtown, Tennessee. . . . . . . . . . . . . . . . . . 187

Pigeon River at Newport, Tennessee ... . . . . . . . . . . . . . . . . . . . . . 188

Tuckasegee River at Bryson, North Carolina ....................... 188

Little Tennessee River at Judson, North Carolina................... 189

Hiwassee River at Murphy, North Carolina .... . . . . . . . . . . . . . . . . . . 190

Hiwassee River at Reliance, Tennessee ... . . . . . . . . . . . . . . . . . . . . . . 191

Hiwassee River at Charleston, Tennessee .......................... 192

Toccoa River near Blueridge, Georgia _ .......................... 193

Tennessee River at Knoxville, Tennessee . . . . . . ...................... 193

Tennessee River at Chattanooga, Tennessee ....................... 195 


\title{
OPERATIONS AT RIVER STATIONS, 1900.
}

\author{
PA'RT II.
}

\section{MEASUREMENTS AT RIVER STATIONS.'}

WISSAHICKON CREEK NEAR PHILAdELPHIA, PENNSYlVANIA.

This station is described in the Twentieth Annual Report, Part IV, page 94 , followed by tables of monthly flow for 1897 and 1898 . In Water-Supply Paper No. 35, page 74, will be found the figures for the daily discharge for 1899 , ending with June 5 , when the observations were discontinued temporarily, and were not again resumed until July 1, 1900. The figures for monthly flow for 1899 and diagrams of daily discharge for the entire period of observation (1897 to 1899, inclusive) will be found in the Twenty-first Annual Report, Part IV, pages 81 and 82 . The following tables contain the figures for the daily discharge from which the diagrams were constructed, as well as those for 1900 , diagram for which is not yet plotted.

Daily discharge, in second-feet, of Wissahickon Creek near Philadelphia, Pennsylvania, for $189 \%$.

[Drainage area, 64.6 square miles.]

\begin{tabular}{|c|c|c|c|c|c|c|c|c|}
\hline Day. & May. & June. & July. & Aug. & Sept. & Oct. & Nov. & Dec. \\
\hline $\begin{array}{l}1 \\
12 \\
35\end{array}$ & $\begin{array}{r}78 \\
93 \\
75 \\
71 \\
71 \\
73 \\
74 \\
77 \\
345 \\
182 \\
140 \\
117 \\
98 \\
86 \\
84 \\
79 \\
77 \\
99 \\
91 \\
85 \\
204 \\
89 \\
77 \\
72 \\
69 \\
110 \\
216\end{array}$ & $\begin{array}{r}84 \\
87 \\
74 \\
137 \\
168 \\
117 \\
75 \\
132 \\
1,384 \\
228 \\
152 \\
141 \\
131 \\
121 \\
105 \\
112 \\
103 \\
111 \\
97 \\
100 \\
103 \\
88 \\
84 \\
81 \\
74 \\
73 \\
70 \\
68 \\
67 \\
67 \\
-. .\end{array}$ & $\begin{array}{r}62 \\
72 \\
63 \\
60 \\
56 \\
56 \\
53 \\
57 \\
32 \\
32 \\
32 \\
54 \\
50 \\
59 \\
43 \\
51 \\
41 \\
36 \\
90 \\
64 \\
96 \\
2,817 \\
187 \\
268 \\
139 \\
121 \\
131 \\
763 \\
336 \\
2323 \\
184\end{array}$ & $\begin{array}{r}162 \\
148 \\
139 \\
131 \\
134 \\
128 \\
120 \\
108 \\
119 \\
117 \\
160 \\
110 \\
101 \\
90 \\
550 \\
497 \\
158 \\
108 \\
97 \\
93 \\
82 \\
79 \\
88 \\
388 \\
142 \\
97 \\
91 \\
85 \\
78 \\
80 \\
79\end{array}$ & $\begin{array}{r}76 \\
102 \\
74 \\
55 \\
59 \\
67 \\
67 \\
53 \\
52 \\
52 \\
36 \\
49 \\
68 \\
35 \\
32 \\
32 \\
35 \\
35 \\
35 \\
35 \\
30 \\
29 \\
31 \\
41 \\
33 \\
34 \\
33 \\
36 \\
49 \\
45\end{array}$ & $\begin{array}{l}41 \\
25 \\
24 \\
29 \\
32 \\
30 \\
29 \\
29 \\
28 \\
27 \\
26 \\
32 \\
33 \\
30 \\
29 \\
28 \\
24 \\
24 \\
24 \\
25 \\
26 \\
31 \\
30 \\
28 \\
74 \\
89 \\
39 \\
30 \\
29 \\
29 \\
27\end{array}$ & $\begin{array}{r}68 \\
432 \\
132 \\
77 \\
65 \\
46 \\
45 \\
48 \\
54 \\
75 \\
57 \\
53 \\
45 \\
35 \\
39 \\
28 \\
32 \\
34 \\
40 \\
35 \\
33 \\
39 \\
42 \\
40 \\
30 \\
51 \\
211 \\
98 \\
68 \\
65 \\
\ldots . . .\end{array}$ & $\begin{array}{r}65 \\
65 \\
65 \\
74 \\
276 \\
273 \\
136 \\
86 \\
75 \\
75 \\
75 \\
7 \quad 75 \\
93 \\
93 \\
296 \\
833 \\
162 \\
133 \\
111 \\
103 \\
98 \\
94 \\
105 \\
94 \\
84 \\
80 \\
73 \\
75 \\
75 \\
77 \\
82 \\
111\end{array}$ \\
\hline Mes & 95 & 148 & 204 & 147 & 47 & 32 & 71 & 127 \\
\hline
\end{tabular}

${ }^{1}$ Continued from Water-Supply and Irrigation Paper No. 47. 
Daily discharge, in second-feet, of Wissahickon Creek near Philadelphia, Pennsylvania, for 1898.

\begin{tabular}{|c|c|c|c|c|c|c|c|c|c|c|c|c|}
\hline Day. & Jan. & Feb. & Mar. & Apr. & May. & June. & July. & Aug. & Sept. & Oct. & Nov. & Dec. \\
\hline & 118 & 113 & 118 & 143 & 98 & 94 & 44 & 29 & 24 & 19 & 46 & 129 \\
\hline & 91 & 110 & 115 & 110 & 89 & 93 & 34 & 30 & 24 & 10 & 29 & 107 \\
\hline 3 & 80 & 113 & 119 & 101 & 73 & 86 & 35 & 68 & 24 & 18 & 24 & 103 \\
\hline 4 & 74 & 118 & 115 & 93 & 77 & 84 & 35 & 79 & 24 & 18 & 26 & 3.54 \\
\hline 5 & 70 & 116 & 110 & 101 & 79 & 80 & 34 & 164 & 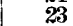 & 19 & 24 & 923 \\
\hline & 71 & 108 & 110 & 101 & $\tilde{*}$ & 79 & 34 & 108 & 2 & 18 & 23 & 182 \\
\hline 7 & 75 & 98 & 110 & 101 & 111 & $\tilde{79}$ & 34 & 64 & 2 & 16 & 27 & 142 \\
\hline 8 & 71 & 93 & 103 & 100 & 744 & $\pi$ & 33 & 64 & 2 & 17 & 33 & 125 \\
\hline & 64 & 93 & 94 & 91 & 256 & 79 & 32 & 66 & 20 & 17 & 29 & 110 \\
\hline 10. & 68 & 93 & 93 & 87 & 136 & 78 & 32 & 84 & 2 & 16 & 170 & 101 \\
\hline 11. & 67 & 104 & 96 & 87 & 125 & 74 & 31 & 158 & 2 & 15 & 248 & 93 \\
\hline 12 & 97 & 146 & 96 & 87 & 125 & 70 & 30 & 12 & 26 & 17 & 82 & 93 \\
\hline 13 . & 136 & 143 & 91 & 87 & 235 & 68 & 30 & 118 & $\boldsymbol{2}$ & 19 & 63 & 93 \\
\hline 14 & 105 & 108 & 91 & 93 & 118 & 68 & 29 & 83 & 21 & $\overline{2} 1$ & 65 & 93 \\
\hline 15 & 215 & 108 & 87 & 93 & 281. & 60 & 29 & 7 & 2 & 24 & 75 & 86 \\
\hline 16 . & 177 & 96 & 84 & 87 & 242 & 64 & 30 & 79 & 21 & 25 & 70 & 80 \\
\hline 17 . & 105 & 93 & 86 & 79 & 323 & 70 & 28 & 108 & 21 & 18 & 79 & 79 \\
\hline 18 . & 78 & 93 & 84 & 75 & 139 & 66 & 26 & 41 & 2 & 20 & 125 & 75 \\
\hline 19. & 75 & 120 & 82 & 75 & $\begin{array}{l}105 \\
131\end{array}$ & 61 & 28 & 8 & 1 : & 29 & 918 & 84 \\
\hline 20 . & 132 & 1,512 & 79 & 79 & 155 & 62 & 30 & 123 & 19 & 28 & 176 & 294 \\
\hline 21 . & 223 & 338 & 89 & 79 & 230 & 61 & 32 & 65 & 1 & 37 & 104 & 143 \\
\hline & 134 & 210 & 101 & 75 & 125 & 55 & 64 & 5 & 1 & 61 & 89 & 129 \\
\hline $23:$ & 751 & 158 & 105 & 75 & 110 & 55 & 64 & 44 & 2 & 35 & 140 & 531 \\
\hline 24 & 193 & 140 & 113 & 108 & 128 & 55 & 32 & 40 & 3 & & 141 & 166 \\
\hline & 140 & 133 & 113 & 122 & 128 & 54 & 30 & 5 & 2 & 22 & 118 & 122 \\
\hline 26. & 205 & 130 & 93 & 107 & 146 & 54 & 48 & 42 & 25 & 47 & 118 & 115 \\
\hline & 201 & 128 & 84 & 98 & 116 & 46 & 243 & 42 & 26 & 70 & 100 & 98 \\
\hline & 128 & 124 & 104 & 225 & 113 & 125 & 79 & 26 & 2 & 60 & 100 & 80 \\
\hline & 125 & ...... & 157 & 235 & 107 & 79 & 50 & 27 & 20 & 44 & 168 & 84 \\
\hline & 118 & 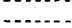 & 357 & 107 & 107 & 60 & 34 & 70 & 19 & 31 & 129 & 101 \\
\hline & 113 & & 138 & $\cdots$ & 100 & & 31 & 67 & & 48 & 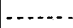 & 143 \\
\hline Mean & 139 & 176 & 110 & 103 & 162 & 71 & 43 & 111 & 22 & 28 & 118 & 165 \\
\hline
\end{tabular}

Daily discharge, in second-feet, of Wissahickon Creek near Philadelphia, Pennsylvania, for 1899.

\begin{tabular}{r|r|r|r|r|r|r||r|r|r|r|r|r|r}
\hline Day. & Jan. & Feb. & Mar. & Apr. & May. & June. & Day. & Jan. & Feb. & Mar. & Apr. & May. & June. \\
\hline & & & & & & & & & & \\
\hline
\end{tabular}


Daily discharge, in second-feet, of Wissahickon Creek near Philadelphia, Pennsylvania, for 1900 .

\begin{tabular}{|c|c|c|c|c|c|c|c|c|c|c|c|c|c|}
\hline Day. & July. & Aug. & Sept. & Oct. & Nor. & Dec. & Day. & July. & Aug. & Sept. & Oct. & Nov. & Dec. \\
\hline & 15 & 47 & 16 & 64 & 1 & 22 & & 1 & 59 & 39 & 25 & 11 & \\
\hline & 17 & 24 & 15 & 40 & $1 \%$ & 24 & $\begin{array}{l}10 \\
19\end{array}$ & $\begin{array}{r}10 \\
9\end{array}$ & 158 & $\begin{array}{l}09 \\
17\end{array}$ & 19 & 12 & 22 \\
\hline 3. & 20 & 20 & 15 & 17 & 15 & 24 & 20 & 10 & 80 & 17 & 19 & 14 & 21 \\
\hline 4. & 17 & 16 & 18 & 15 & 15 & 247 & 21 & 18 & 43 & 14 & 21 & 13 & 21 \\
\hline & 17 & 16 & 15 & 14 & 17 & 219 & 23 & 21 & 27 & 1 & 21 & 12 & 21 \\
\hline 6. & 17 & 17 & 13 & 14 & 18 & $4 \pi$ & 23 & 114 & 22 & 12 & 21 & 11 & 21 \\
\hline & 17 & 20 & 10 & 12 & 14 & 31 & 24 & 114 & 26 & 13 & 20 & 10 & 21 \\
\hline & 20 & 17 & 9 & $\boldsymbol{z}^{\prime \prime}$ & 14 & 38 & 25 & 19 & 31 & 13 & 17 & 11 & 21 \\
\hline 9. & 17 & 17 & 8 & 54 & 16 & 38 & 26 & 116 & 22 & 10 & 17 & $36 \tilde{u}$ & 20 \\
\hline 10. & 17 & 15 & 13 & 47 & 15 & 38 & $2 \pi$ & 83 & 47 & 10 & 14 & 86 & 20 \\
\hline 11 & 16 & 12 & 13 & 23 & 10 & 52 & 28 & 26 & 40 & 13 & 12 & 26 & 20 \\
\hline 12. & 40 & 98 & 9 & 15 & 15 & 62 & 29 & 17 & 40 & 13 & 15 & 20 & 20 \\
\hline 13. & 54 & 31 & 8 & 16 & 18 & 41 & 30 & 176 & 32 & 37 & 17 & 25 & 20 \\
\hline 14. & 32 & 31 & 9 & 274 & 14 & 24 & 31 & 219 & 27 & & 15 & & 20 \\
\hline & 15 & 24 & 12 & 92 & 13 & 31 & \multirow{3}{*}{ Mean .. } & \multirow{3}{*}{42} & & & & & \\
\hline & 13 & 18 & 278 & 54 & 11 & 30 & & & \multirow[t]{2}{*}{35} & \multirow[t]{2}{*}{$260^{\circ}$} & \multirow[t]{2}{*}{34} & \multirow[t]{2}{*}{29} & \multirow[t]{2}{*}{42} \\
\hline & 15 & 18 & 85 & 35 & 11 & 28 & & & & & & & \\
\hline
\end{tabular}

SCHUYLKILL RIVER ABOVE PHILADELPHIA, PENNSYLVANIA.

This river is described in Water-Supply Paper No. 35, page 74. Records of the height of the river at Fairmount dam have been kept for many years, but measurements for computing the daily discharge were not made until 1898. The first of the following tables does not represent the total flow of the stream, but the amount wasted over the flashboards at the dam, to which must be added the pumpage from the river, the leakage, and the quantity used for power at Fairmount. The second table is an estimate of the total monthly yield, in cubic feet, including the foregoing items. The figures were furnished by $\mathrm{Mr}$. John E. Codman, hydrographer for the water department of the city of Philadelphia.

Daily discharge, in second-feet, of Schuylkill River above Philadelphia, Pennsylvania, for 1900, being amount wasted over flashboards at Fairmount dam.

\begin{tabular}{|c|c|c|c|c|c|c|c|}
\hline Day. & Jan. & Feb. & Mar. & Apr. & May. & July. & Dec. \\
\hline & & & 5,526 & $1,02 \pi$ & & & \\
\hline $3 \ldots$ & & & $\begin{array}{l}19.061 \\
13,197\end{array}$ & $\begin{array}{l}880 \\
613\end{array}$ & & & .. \\
\hline & & & $\begin{array}{l}10,1718 \\
7,318\end{array}$ & $20 \%$ & & & \\
\hline$=$ & & 15,673 & 5,122 & 148 & ....... & …...... & 2,041 \\
\hline $\begin{array}{l}6 . \\
7 .\end{array}$ & $\cdots$ & $\begin{array}{l}8,105 \\
3,077\end{array}$ & $\begin{array}{l}5,814 \\
3,814\end{array}$ & 260 & & ......... & $\begin{array}{l}2,041 \\
1,362\end{array}$ \\
\hline $8 .-$ & $\cdots$ & $\begin{array}{l}3,890 \\
3,890\end{array}$ & $\begin{array}{l}3,014 \\
3,146 \\
\end{array}$ & 378 & & & $\begin{array}{lll}1,040 \\
644\end{array}$ \\
\hline $10 .-$ & & 5,618 & 2,277 & 378 & & & \\
\hline $11 .$. & & 1,712 & 2076 & 260 & & & \\
\hline & 7,013 & 1,348 & 1,551 & & & & \\
\hline$\cdots$ & & 14,009 & 1,027 & 238 & & & \\
\hline$\cdots$ & $\cdots$ & 15,905 & 1,027 & 238 & & 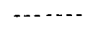 & - \\
\hline & & & 1,027 & & & & \\
\hline & ...... & 5,706 & 758 & & & & . \\
\hline & & (2, 489 & 369 & & & & $\because$ \\
\hline & & 2,076 & 477 & 1,697 & 4,103 & $\ldots$ & \\
\hline - n & 1,222 & 1,095 & 4,243 & 1,404 & 6,243 & & \\
\hline 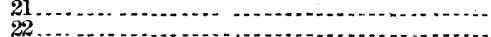 & 3,579 & 1,349 & 9,731 & 497 & 923 & & 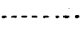 \\
\hline 1. & 2,198 & 14,183 & 3,641 & 411 & & & \\
\hline & 1,275 & 21,798 & 2,477 & 519 & & 80 & \\
\hline & 685 & $\begin{array}{r}12,020 \\
8,235\end{array}$ & & 130 & & & \\
\hline$\cdots$ & 675 & $\begin{array}{l}0,742 \\
4,742\end{array}$ & $\begin{array}{l}1,699 \\
1,69\end{array}$ & $\ldots$ & 311 & 2,861 & . \\
\hline & 450 & 4,642 & 2,088 & & 211 & 2,525 & .......... \\
\hline & 225 & 2,076 & 2,088 & & & 923 & \\
\hline 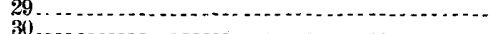 & 156 & & 1,524 & - & $\cdots$ & . & (......... \\
\hline & & & 1,188 & & & ......... & ..... \\
\hline
\end{tabular}

NoTE.-The amount wasted over the flashboards on June 28 was 1,088 second-feet. on August 13 it was 79 second-feet, and on November 27 and $₫ 8$ it was 43 and 18 second-feet, respectively. 
Total monthly yield of Schuykill River above Philadelphia, Pennsylvania, for 1900.

\begin{tabular}{|c|c|c|c|}
\hline Month. & Yield. & Month. & Yield. \\
\hline $\begin{array}{l}\text { January } \\
\text { February } \\
\text { March } \\
\text { April } \\
\text { May } \\
\text { June }\end{array}$ & $\begin{array}{r}\text { Cubic feet. } \\
6,610,500,000 \\
33,771,128,000 \\
14,666,146,000 \\
5,730,472,000 \\
5,073,978,000 \\
2,743,671,000\end{array}$ & $\begin{array}{l}\text { July } \\
\text { Angust } \\
\text { September } \\
\text { October } \\
\text { November } \\
\text { December }\end{array}$ & $\begin{array}{l}\text { Cubic feet. } \\
2,856,566,000 \\
2,040,927,000 \\
1,229,059,000 \\
1,372,271,000 \\
1,579,652,000 \\
3,429,617,000\end{array}$ \\
\hline
\end{tabular}

NORTH BRANCH OF SUSQUEHANNA RIVER AT WILKESBARRE, PENNSYLVANIA.

This station, which was established by E. G. Paul March 30, 1899, is described in Water-Supply Paper No. 35, page 76. The results of measurements for 1899 will be found in the Twenty-first Annual Report, Part IV, page 88. A bench mark was established September 26, 1900, being the extreme west end of the stone doorsill of the north entrance to the Coal Exchange Building, at 32.99 feet above datum of the gage. During 1900 two measurements of discharge were made by $\mathrm{Mr}$. Paul, as follows:

May 20: Gage height, 5.60 feet; discharge, 6,772 second-feet.

September 26: Gage height, 2.20 feet; discharge, 961 second-feet.

The measurement of September 26 was made at Retreat, Pennsylvania, 10 miles below Wilkesbarre.

Daily gage height, in feet, of North Branch of Susquehanna River at Wilkesbarre, Pennsylvania, for 1900 .

\begin{tabular}{|c|c|c|c|c|c|c|c|c|c|c|c|c|}
\hline De & Jan. & Feb. & Mar. & Apr. & May. & June. & July. & Aug. & Sept. & Oct. & Nov. & Dec. \\
\hline $\begin{array}{r}1 \\
2 \\
3 \\
3 \\
4 \\
5 \\
6 \\
7 \\
8 \\
8 \\
9 \\
10 \\
11\end{array}-$ & $\begin{array}{r}6.80 \\
6.20 \\
6.40 \\
6.80 \\
7.00 \\
7.00 \\
6.90 \\
6.80 \\
6.50 \\
6.10 \\
5.80 \\
5.90 \\
5.60 \\
5.90 \\
5.60 \\
5.50 \\
5.50 \\
5.20 \\
5.10 \\
5.80 \\
14.65 \\
16.85 \\
13.50 \\
10.30 \\
8.50 \\
7.80 \\
7.90 \\
6.20 \\
9.20 \\
9.00 \\
8.70\end{array}$ & $\begin{array}{r}7.40 \\
6.80 \\
6.30 \\
650 \\
8.40 \\
8.50 \\
7.90 \\
7.80 \\
14.45 \\
9.20 \\
9.80 \\
9.20 \\
9.20 \\
12.10 \\
13.65 \\
11.80 \\
9.20 \\
7.70 \\
8.90 \\
10.70 \\
9.80 \\
11.40 \\
16.10 \\
14.75 \\
11.00 \\
8.80 \\
7.00 \\
8.50\end{array}$ & $\begin{array}{r}10.40 \\
17.75 \\
14.55 \\
11.80 \\
9.90 \\
8.40 \\
8.20 \\
8.10 \\
7.70 \\
8.40 \\
9.00 \\
7.80 \\
6.80 \\
6.30 \\
5.70 \\
5.70 \\
9.00 \\
8.10 \\
8.30 \\
8.50 \\
10.85 \\
9.70 \\
9.20 \\
8.40 \\
9.90 \\
8.70 \\
8.10 \\
7.10 \\
7.00 \\
6.80 \\
6.50\end{array}$ & $\begin{array}{r}6.90 \\
7.50 \\
9.80 \\
11.20 \\
11.10 \\
9.40 \\
9.60 \\
11.70 \\
12.20 \\
10.90 \\
9.20 \\
7.90 \\
7.30 \\
7.70 \\
8.10 \\
7.80 \\
7.60 \\
10.03 \\
12.45 \\
12.40 \\
11.10 \\
10.00 \\
9.50 \\
11.30 \\
10.70 \\
9.50 \\
8.40 \\
7.50 \\
6.90 \\
6.50\end{array}$ & $\begin{array}{l}6.10 \\
5.80 \\
5.50 \\
5.30 \\
5.20 \\
5.00 \\
4.80 \\
4.70 \\
4.60 \\
4.50 \\
4.50 \\
4.80 \\
4.90 \\
4.80 \\
4.70 \\
4.70 \\
4.90 \\
5.00 \\
\mathbf{5 . 1 0} \\
\mathbf{5 . 6 0} \\
\mathbf{5 . 2 0} \\
\mathbf{5 . 0 0} \\
4.80 \\
4.60 \\
4.50 \\
4.30 \\
4.10 \\
4.00 \\
3.90 \\
\mathbf{3} .80 \\
3.70\end{array}$ & $\begin{array}{l}3.80 \\
3.70 \\
4.20 \\
3.90 \\
3.70 \\
3.80 \\
3.70 \\
3.60 \\
3.60 \\
3.80 \\
3.90 \\
4.30 \\
4.30 \\
4.80 \\
4.30 \\
4.00 \\
3.80 \\
3.60 \\
3.50 \\
3.40 \\
3.30 \\
3.20 \\
3.50 \\
3.30 \\
3.30 \\
3.20 \\
3.20 \\
3.10 \\
3.10 \\
3.10\end{array}$ & $\begin{array}{l}3.00 \\
2.80 \\
2.70 \\
2.90 \\
2.90 \\
3.40 \\
3.90 \\
3.60 \\
3.40 \\
3.20 \\
3.10 \\
2.90 \\
3.00 \\
3.00 \\
3.00 \\
3.00 \\
2.90 \\
2.90 \\
2.80 \\
3.10 \\
3.20 \\
3.10 \\
3.00 \\
2.90 \\
2.90 \\
4.00 \\
3.70 \\
3.40 \\
3.20 \\
3.30 \\
3.30 \\
.\end{array}$ & $\begin{array}{l}3.20 \\
3.20 \\
3.00 \\
2.90 \\
2.90 \\
2.90 \\
2.90 \\
2.90 \\
2.90 \\
2.80 \\
2.80 \\
2.70 \\
2.70 \\
2.60 \\
2.60 \\
2.60 \\
2.50 \\
2.50 \\
2.40 \\
2.50 \\
2.50 \\
2.50 \\
2.80 \\
3.00 \\
2.90 \\
2.60 \\
.70 \\
.80 \\
2.80 \\
3.10 \\
3.10\end{array}$ & $\begin{array}{l}\boldsymbol{g} .10 \\
3.00 \\
3.10 \\
3.00 \\
2.90 \\
2.80 \\
2.70 \\
2.70 \\
2.60 \\
2.60 \\
2.70 \\
2.70 \\
2.70 \\
2.50 \\
2.40 \\
2.50 \\
2.40 \\
2.30 \\
2.20 \\
2.20 \\
2.10 \\
2.20 \\
2.20 \\
2.20 \\
2.20 \\
2.20 \\
2.30 \\
2.20 \\
2.20 \\
2.30 \\
\cdots . . . \\
\end{array}$ & $\begin{array}{l}2.30 \\
2.30 \\
2.30 \\
2.30 \\
2.30 \\
2.20 \\
2.10 \\
2.10 \\
2.20 \\
2.20 \\
2.20 \\
2.20 \\
2.20 \\
2.20 \\
2.20 \\
2.30 \\
2.40 \\
2.40 \\
2.50 \\
2.70 \\
2.60 \\
2.60 \\
2.70 \\
2.90 \\
2.80 \\
2.80 \\
2.70 \\
2.70 \\
2.70 \\
2.70 \\
2.60\end{array}$ & $\begin{array}{r}2.70 \\
2.60 \\
2.60 \\
2.50 \\
2.70 \\
2.80 \\
3.00 \\
2.90 \\
2.90 \\
2.90 \\
3.00 \\
3.10 \\
3.30 \\
3.50 \\
3.50 \\
3.40 \\
3.30 \\
3.20 \\
3.20 \\
3.10 \\
3.10 \\
3.20 \\
3.60 \\
4.00 \\
4.30 \\
4.70 \\
16.75 \\
20.75 \\
14.65 \\
11.80 \\
\end{array}$ & $\begin{array}{r}10.50 \\
9.20 \\
8.10 \\
7.40 \\
9.20 \\
11.90 \\
11.30 \\
9.90 \\
8.90 \\
8.20 \\
7.50 \\
6.60 \\
6.20 \\
6.10 \\
210.30 \\
9.80 \\
9.20 \\
8.70 \\
9.20 \\
9.60 \\
9.40 \\
9.10 \\
\ldots \ldots . \\
\ldots . . \\
\ldots . . \\
\ldots \ldots . \\
\ldots . .2 \\
11.40 \\
11.40\end{array}$ \\
\hline
\end{tabular}

$a$ Ice backed water at gage. 
This station, which was established March 25, 1899, by E. G. Paul, is described in Water-Supply Paper No. 35, page 77. The results of measurements for 1899 will be found in the Twenty-first Annual Report, Part IV, page 89. A bench mark was established, being the extreme south end of the stone doorsill at the east entrance of the city filtering plant, at 31.7 feet above datum of the gage. During 1900 two measurements were made by Mr. Paul, as follows:

May 20: Gage height, 4.60 feet; discharge, 10,515 second-feet.

September 25: Gage height, 1.60 foot; discharge, 822 second-feet.

Daily gage height, in feet, of North Branch of Susquehanna River at Danville, Pennsylvania, for 1900 .

\begin{tabular}{|c|c|c|c|c|c|c|c|c|c|c|c|c|}
\hline Day. & Jan. & Feb. & Mar. & Apr. & May. & June. & July. & Ang. & Sept. & Oct. & Nov. & Dec. \\
\hline 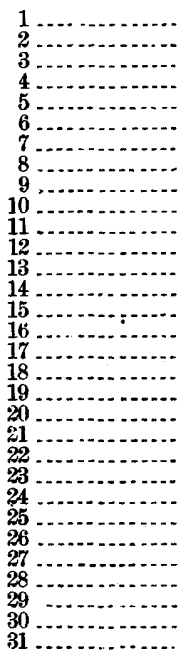 & $\begin{array}{c}(a) \\
(a) \\
(a) \\
(a) \\
(a) \\
(a) \\
(a) \\
(a) \\
(a) \\
(a) \\
(a) \\
(a) \\
(a) \\
(a) \\
(a) \\
(a) \\
(a) \\
(a) \\
(a) \\
(a) \\
9.40 \\
12.70 \\
11.95 \\
9.70 \\
7.80 \\
6.80 \\
6.45 \\
6.30 \\
5.80 \\
5.80 \\
(a)\end{array}$ & $\begin{array}{r}(a) \\
(a) \\
(a) \\
(a) \\
(a) \\
(a) \\
(a) \\
(a) \\
(a) \\
9.70 \\
9.90 \\
7.60 \\
7.80 \\
9.40 \\
9.60 \\
11.20 \\
10.40 \\
8.30 \\
7.30 \\
5.70 \\
5.00 \\
4.70 \\
5.95 \\
12.15 \\
13.50 \\
11.05 \\
8.95 \\
6.85 \\
5.45\end{array}$ & $\begin{array}{r}7.55 \\
15.25 \\
13.10 \\
10.65 \\
9.25 \\
7.10 \\
7.10 \\
7.30 \\
6.85 \\
6.75 \\
7.50 \\
7.20 \\
6.40 \\
5.65 \\
5.20 \\
4.90 \\
4.70 \\
4.90 \\
5.05 \\
5.10 \\
7.95 \\
7.80 \\
7.95 \\
7.40 \\
7.40 \\
7.65 \\
6.95 \\
5.85 \\
5.90 \\
5.65\end{array}$ & $\begin{array}{r}5.60 \\
5.80 \\
6.75 \\
8.40 \\
9.30 \\
8.45 \\
7.40 \\
8.70 \\
9.75 \\
9.45 \\
8.25 \\
7.10 \\
6.30 \\
6.10 \\
6.30 \\
6.65 \\
6.35 \\
7.00 \\
9.75 \\
10.55 \\
9.85 \\
8.95 \\
8.10 \\
8.35 \\
9.30 \\
8.40 \\
7.40 \\
6.65 \\
6.10 \\
5.65\end{array}$ & $\begin{array}{l}5.35 \\
.3 .05 \\
4.80 \\
4.55 \\
4.40 \\
4.25 \\
4.15 \\
4.05 \\
4.00 \\
3.95 \\
3.85 \\
3.90 \\
4.10 \\
4.20 \\
4.00 \\
4.00 \\
3.80 \\
3.90 \\
3.90 \\
4.40 \\
4.40 \\
4.10 \\
3.90 \\
3.70 \\
3.60 \\
3.60 \\
3.40 \\
3.20 \\
3.20 \\
3.10 \\
3.00\end{array}$ & $\begin{array}{l}3.00 \\
2.90 \\
2.90 \\
3.50 \\
3.30 \\
3.10 \\
3.00 \\
2.90 \\
2.90 \\
2.90 \\
3.10 \\
3.10 \\
3.30 \\
3.30 \\
3.90 \\
3.90 \\
3.20 \\
3.00 \\
3.00 \\
2.90 \\
2.80 \\
2.70 \\
2.60 \\
2.60 \\
2.70 \\
2.60 \\
2.50 \\
2.50 \\
2.40 \\
2.40\end{array}$ & $\begin{array}{l}2.30 \\
2.30 \\
2.30 \\
2.20 \\
2.20 \\
2.30 \\
2.70 \\
2.90 \\
2.90 \\
2.70 \\
2.50 \\
2.50 \\
2.40 \\
2.30 \\
2.30 \\
2.30 \\
2.30 \\
2.30 \\
2.30 \\
2.30 \\
2.20 \\
2.40 \\
2.30 \\
2.20 \\
2.10 \\
2.30 \\
3.00 \\
2.80 \\
2.60 \\
2.40 \\
2.40\end{array}$ & $\begin{array}{l}2.40 \\
2.40 \\
2.30 \\
2.20 \\
2.20 \\
2.10 \\
2.50 \\
2.20 \\
2.10 \\
2.10 \\
2.00 \\
2.00 \\
1.90 \\
2.00 \\
2.00 \\
1.90 \\
1.90 \\
1.90 \\
1.80 \\
1.80 \\
1.90 \\
1.90 \\
1.80 \\
1.80 \\
2.30 \\
2.10 \\
2.20 \\
2.10 \\
2.00 \\
2.00 \\
2.00\end{array}$ & $\begin{array}{l}2.20 \\
2.20 \\
2.20 \\
2.20 \\
2.20 \\
2.10 \\
2.10 \\
2.00 \\
1.80 \\
1.90 \\
1.80 \\
1.80 \\
1.80 \\
1.80 \\
1.80 \\
1.80 \\
1.70 \\
1.70 \\
1.70 \\
1.70 \\
1.70 \\
1.70 \\
1.60 \\
1.60 \\
1.60 \\
1.70 \\
1.70 \\
1.70 \\
1.70 \\
1.70\end{array}$ & $\begin{array}{l}1.70 \\
1.70 \\
1.70 \\
1.70 \\
1.70 \\
1.70 \\
1.70 \\
1.70 \\
1.70 \\
1,70 \\
1.70 \\
1.70 \\
1.80 \\
1.80 \\
1.80 \\
1.80 \\
1.80 \\
1.70 \\
1.70 \\
1.90 \\
2.10 \\
2.30 \\
2.20 \\
2.10 \\
2.10 \\
2.10 \\
2.00 \\
2.00\end{array}$ & \begin{tabular}{|l}
2.00 \\
2.00 \\
2.00 \\
2.00 \\
2.00 \\
2.00 \\
2.00 \\
2.00 \\
2.00 \\
2.00 \\
2.10 \\
2.20 \\
2.40 \\
2.40 \\
2.60 \\
2.50 \\
2.50 \\
2.50 \\
2.50 \\
2.50 \\
2.50 \\
2.60 \\
2.70 \\
2.90 \\
3.90 \\
8.45 \\
16.60 \\
12.65 \\
10.20
\end{tabular} & $\begin{array}{l}8.75 \\
7.15 \\
5.90 \\
5.50 \\
7.10 \\
8.80 \\
9.65 \\
8.55 \\
7.50 \\
6.85 \\
6.30 \\
5.55 \\
5.20 \\
5.00 \\
5.00 \\
6.80 \\
(a) \\
(a) \\
(a) \\
(a) \\
(a) \\
(a) \\
(a) \\
(a) \\
(a) \\
70.05 \\
8.60 \\
75.55 \\
6.95 \\
6.55 \\
6.30\end{array}$ \\
\hline
\end{tabular}

$a$ River frozen.

WEST BRANCH OF SUSQUEHANNA RIVER AT ALLENWOOD, PENNSYLVANIA.

This station, which was established by E. G. Paul March 23, 1899, is described in Water-Supply Paper No. 35, page 78. The results of measurements for 1899 will be found in the Twenty-first Annual Report, Part IV, page 90. A bench mark was established on September 24,1900 . It consists of a copper bolt set in the capstone of the wing wall on the lower side of the west end of the bridge, and is 33.19 feet above datum of the gage. During 1900 two measurements of discharge were made by Mr. Paul, as follows:

May 19: Gage height, 3.2 feet; discharge, 4,812 second-feet.

September 24: Gage height, 1.8 feet; discharge, 511 second-feet. 
Daily gage height, in feet, of West Branoh of Susquehanna River at Allenwood, Pennsylvaniu, for 1900.

\begin{tabular}{|c|c|c|c|c|c|c|c|c|c|c|c|c|}
\hline $\mathrm{Da}$ & Jan. & Feb. & Mar. & Apr. & May. & June. & July. & Aug. & Sept. & Oct. & Nov. & Dec. \\
\hline $\begin{array}{r}1 \\
2 \\
3 \\
4 \\
5 \\
6 \\
7 \\
8 \\
9 \\
10 \\
11 \\
12 \\
13 \\
14 \\
15 \\
16 \\
17 \\
18 \\
19 \\
20 \\
21\end{array}$ & $\begin{array}{r}4.50 \\
5.50 \\
5.70 \\
\mathbf{5 . 8 0} \\
\mathbf{5 . 9 0} \\
\mathbf{5 . 9 0} \\
\mathbf{5 . 9 0} \\
4.70 \\
3.70 \\
3.90 \\
4.20 \\
4.50 \\
4.40 \\
4.20 \\
4.00 \\
4.00 \\
4.00 \\
4.20 \\
4.50 \\
\mathbf{5 . 3 0} \\
13.20 \\
12.20 \\
8.50 \\
\mathbf{6} .50 \\
\mathbf{6 . 3 0} \\
\mathbf{6} .10 \\
\mathbf{5 . 3 0} \\
4.60 \\
4.60 \\
4.50 \\
3.20\end{array}$ & \begin{tabular}{r}
3.20 \\
3.20 \\
3.40 \\
3.40 \\
3.50 \\
3.60 \\
3.80 \\
4.50 \\
5.00 \\
5.30 \\
5.60 \\
5.30 \\
6.00 \\
7.70 \\
7.30 \\
6.50 \\
6.20 \\
5.40 \\
5.60 \\
5.90 \\
6.00 \\
8.20 \\
10.15 \\
7.85 \\
6.50 \\
5.00 \\
5.00 \\
4.80 \\
$\cdots \ldots .$. \\
\hdashline$\ldots . .$. \\
$\cdots \ldots .$.
\end{tabular} & $\begin{array}{l}7.55 \\
9.60 \\
7.70 \\
7.00 \\
6.00 \\
5.40 \\
5.80 \\
5.90 \\
6.10 \\
6.40 \\
6.90 \\
6.20 \\
5.40 \\
5.00 \\
4.00 \\
4.00 \\
3.90 \\
3.80 \\
3.70 \\
6.20 \\
7.10 \\
6.90 \\
6.60 \\
6.10 \\
5.90 \\
5.50 \\
5.20 \\
5.10 \\
5.00 \\
4.90 \\
4.80\end{array}$ & $\begin{array}{l}5.00 \\
5.30 \\
5.40 \\
5.80 \\
5.90 \\
6.20 \\
6.40 \\
6.20 \\
7.30 \\
6.00 \\
5.70 \\
5.30 \\
4.90 \\
4.80 \\
4.80 \\
4.60 \\
4.70 \\
6.00 \\
7.00 \\
6.90 \\
6.30 \\
6.20 \\
6.00 \\
6.30 \\
6.00 \\
5.60 \\
5.30 \\
4.80 \\
4.60 \\
4.40\end{array}$ & $\begin{array}{l}4.30 \\
4.20 \\
4.20 \\
4.00 \\
\text { 3. } 80 \\
3.50 \\
3.30 \\
3.30 \\
3.20 \\
\text { 3.20 } \\
3.20 \\
\text { 3.20 } \\
\text { 3.50 } \\
\text { 3.40 } \\
\text { 3.40 } \\
\text { 3.30 } \\
3.20 \\
3.20 \\
3.50 \\
3.50 \\
3.30 \\
3.20 \\
\text { 3.00 } \\
\text { 3. } 00 \\
\text { 3. } 00 \\
\text { 3. } 00 \\
\text { 3.40 } \\
3.20 \\
\text { 3.00 } \\
\text { 3.00 } \\
\text { 3.20 }\end{array}$ & $\begin{array}{r}3.90 \\
3.90 \\
3.90 \\
4.00 \\
4.10 \\
3.90 \\
3.60 \\
3.50 \\
3.40 \\
3.30 \\
3.20 \\
3.00 \\
3.00 \\
3.00 \\
3.00 \\
3.00 \\
2.90 \\
2.80 \\
2.70 \\
2.70 \\
2.60 \\
2.50 \\
2.40 \\
2.40 \\
2.30 \\
2.30 \\
2.30 \\
2.20 \\
2.20 \\
2.10 \\
\ldots \ldots . .\end{array}$ & $\begin{array}{l}2.10 \\
2.30 \\
2.60 \\
2.50 \\
2.30 \\
2.30 \\
2.20 \\
2.20 \\
2.20 \\
2.30 \\
2.50 \\
2.70 \\
2.90 \\
2.80 \\
2.60 \\
2.60 \\
2.50 \\
2.40 \\
2.20 \\
2.00 \\
2.00 \\
1.90 \\
1.90 \\
1.90 \\
1.90 \\
1.90 \\
2.20 \\
2.20 \\
2.20 \\
2.20 \\
2.00\end{array}$ & $\begin{array}{l}1.90 \\
1.80 \\
1.80 \\
1.80 \\
1.70 \\
1.70 \\
1.70 \\
1.60 \\
1.60 \\
1.50 \\
1.40 \\
1.50 \\
1.50 \\
1.40 \\
1.40 \\
1.40 \\
1.40 \\
1.40 \\
1.40 \\
1.40 \\
1.40 \\
2.30 \\
2.30 \\
2.30 \\
2.30 \\
2.30 \\
2.20 \\
2.20 \\
2.10 \\
2.10 \\
2.00\end{array}$ & $\begin{array}{l}2.00 \\
1.90 \\
1.90 \\
1.80 \\
1.80 \\
1.70 \\
1.70 \\
1.70 \\
1.60 \\
1.60 \\
1.60 \\
1.50 \\
1.50 \\
1.40 \\
1.40 \\
1.40 \\
1.30 \\
1.30 \\
1.30 \\
1.30 \\
1.30 \\
1.30 \\
1.30 \\
1.30 \\
1.30 \\
1.30 \\
1.30 \\
1.30 \\
1.30 \\
1.30\end{array}$ & $\begin{array}{l}1.30 \\
1.30 \\
1.20 \\
1.20 \\
1.20 \\
1.20 \\
1.20 \\
1.20 \\
1.80 \\
2.20 \\
2.20 \\
2.10 \\
2.10 \\
2.10 \\
2.10 \\
2.10 \\
2.10 \\
2.20 \\
2.10 \\
2.00 \\
1.90 \\
1.90 \\
2.10 \\
2.20 \\
2.40 \\
2.50 \\
2.60 \\
2.40 \\
2.40 \\
2.20 \\
2.20\end{array}$ & $\begin{array}{r}2.10 \\
2.10 \\
2.10 \\
2.10 \\
2.10 \\
2.00 \\
1.90 \\
1.90 \\
1.90 \\
1.90 \\
1.90 \\
1.90 \\
1.90 \\
1.90 \\
1.90 \\
1.80 \\
1.80 \\
1.80 \\
1.70 \\
1.70 \\
1.70 \\
1.90 \\
2.40 \\
3.00 \\
5.00 \\
7.70 \\
15.75 \\
10.05 \\
8.25 \\
6.60\end{array}$ & $\begin{array}{l}5.75 \\
5.40 \\
5.00 \\
5.80 \\
5.90 \\
6.40 \\
6.70 \\
6.00 \\
5.50 \\
4.90 \\
4.60 \\
4.20 \\
4.00 \\
3.80 \\
3.60 \\
3.30 \\
3.20 \\
3.20 \\
3.10 \\
3.10 \\
3.10 \\
3.00 \\
3.00 \\
3.00 \\
3.00 \\
3.00 \\
3.00 \\
3.00 \\
3.00 \\
3.00\end{array}$ \\
\hline
\end{tabular}

JUNIATA RIVER AT NEWPORT, PENNSYlvaNia.

This station, which was established March 21, 1899, by E. G. Paul, is described in Water-Supply Paper No. 35, page 79. The results of measurements for 1899 will be found in the Twenty-first Annual Report, Part IV, page 91. The bench mark is the extreme east end of the stone doorsill of the south entrance of Butz's store, on the right bank, and is 28.83 feet above datum of the gage. During 1900 two measurements of discharge were made by Mr. Paul, as follows:

May 17: Gage height, 3.40 feet; discharge, 1,778 second-feet. September 22: Gage height, 2.80 feet; discharge, 418 second-feet. 
Daily gage height, in feet, of Juniata River at Newport, Pennsylvania, for 1900.

\begin{tabular}{|c|c|c|c|c|c|c|c|c|c|c|c|c|}
\hline D & Jan. & Feb. & Mar. & Apr. & May. & June. & July. & Aug. & Sept. & Oct. & Nov. & Dec. \\
\hline $\begin{array}{l}20 \\
21\end{array}$ & $\begin{array}{r}4.10 \\
4.10 \\
4.60 \\
5.00 \\
5.00 \\
4.70 \\
5.20 \\
4.00 \\
4.20 \\
4.10 \\
4.10 \\
4.80 \\
4.60 \\
4.20 \\
3.90 \\
3.50 \\
4.10 \\
3.80 \\
4.20 \\
4.90 \\
10.60 \\
10.20 \\
7.20 \\
6.00 \\
5.20 \\
5.00 \\
4.80 \\
4.40 \\
4.40 \\
4.20 \\
4.10\end{array}$ & $\begin{array}{r}3.70 \\
3.40 \\
3.40 \\
3.50 \\
3.80 \\
4.40 \\
4.10 \\
4.20 \\
5.10 \\
5.60 \\
4.80 \\
4.60 \\
5.40 \\
9.40 \\
7.60 \\
5.90 \\
5.30 \\
4.90 \\
4.10 \\
4.20 \\
4.40 \\
11.70 \\
11.10 \\
8.20 \\
5.90 \\
4.50 \\
4.40 \\
4.60 \\
\hdashline . . .2 \\
\hdashline \ldots . . .5 \\
\hdashline . . .6\end{array}$ & $\begin{array}{r}5.90 \\
12.90 \\
8.00 \\
6.00 \\
5.50 \\
5.40 \\
6.00 \\
6.40 \\
5.60 \\
5.40 \\
5.10 \\
5.10 \\
4.90 \\
4.80 \\
4.70 \\
4.60 \\
4.10 \\
4.10 \\
4.10 \\
4.40 \\
6.50 \\
6.50 \\
5.70 \\
5.70 \\
5.60 \\
5.40 \\
5.10 \\
5.00 \\
4.80 \\
4.60 \\
4.50\end{array}$ & $\begin{array}{l}4.50 \\
4.50 \\
4.50 \\
4.40 \\
4.50 \\
4.60 \\
4.50 \\
4.40 \\
4.40 \\
4.40 \\
4.40 \\
4.30 \\
4.30 \\
4.30 \\
4.30 \\
4.10 \\
4.00 \\
4.00 \\
4.40 \\
4.70 \\
4.50 \\
4.50 \\
4.50 \\
4.70 \\
4.70 \\
4.70 \\
4.40 \\
4.30 \\
4.20 \\
4.20\end{array}$ & $\begin{array}{l}4.10 \\
4.10 \\
4.00 \\
3.90 \\
3.80 \\
3.70 \\
3.70 \\
3.70 \\
3.60 \\
3.60 \\
3.50 \\
3.50 \\
3.50 \\
3.50 \\
3.50 \\
3.50 \\
3.40 \\
3.40 \\
3.50 \\
3.70 \\
4.00 \\
3.70 \\
3.70 \\
3.60 \\
3.50 \\
3.50 \\
3.20 \\
3.30 \\
3.30 \\
3.30 \\
3.30\end{array}$ & $\begin{array}{l}3.30 \\
3.30 \\
3.40 \\
3.70 \\
3.60 \\
3.40 \\
3.40 \\
3.30 \\
3.40 \\
3.50 \\
3.40 \\
3.30 \\
3.30 \\
3.30 \\
3.30 \\
3.30 \\
3.30 \\
3.30 \\
3.30 \\
3.30 \\
3.30 \\
3.30 \\
3.30 \\
3.30 \\
3.20 \\
3.20 \\
3.60 \\
\mathbf{3} .40 \\
3.30 \\
\mathbf{3} .30\end{array}$ & $\begin{array}{l}3.30 \\
3.20 \\
3.10 \\
3.10 \\
3.10 \\
3.10 \\
3.10 \\
3.10 \\
3.10 \\
3.10 \\
3.10 \\
3.10 \\
3.10 \\
3.00 \\
3.00 \\
3.00 \\
3.00 \\
3.00 \\
2.90 \\
2.90 \\
2.90 \\
2.90 \\
2.90 \\
3.20 \\
3.10 \\
3.10 \\
3.10 \\
3.10 \\
3.00 \\
3.00 \\
3.00\end{array}$ & $\begin{array}{l}\text { 3.00 } \\
3.00 \\
3.00 \\
3.00 \\
3.00 \\
3.00 \\
2.90 \\
2.90 \\
2.90 \\
2.80 \\
2.80 \\
2.80 \\
2.80 \\
2.80 \\
2.80 \\
2.80 \\
2.80 \\
2.80 \\
2.80 \\
2.80 \\
2.80 \\
2.80 \\
2.80 \\
2.80 \\
3.30 \\
3.30 \\
3.70 \\
3.40 \\
3.30 \\
3.70 \\
3.60\end{array}$ & $\begin{array}{l}3.30 \\
3.20 \\
3.20 \\
3.10 \\
2.90 \\
2.90 \\
2.90 \\
2.80 \\
2.80 \\
2.80 \\
2.80 \\
2.80 \\
2.80 \\
2.80 \\
2.80 \\
2.80 \\
2.80 \\
2.80 \\
2.80 \\
2.80 \\
2.80 \\
2.80 \\
2.80 \\
2.80 \\
2.80 \\
2.80 \\
2.80 \\
2.80 \\
2.80 \\
2.80\end{array}$ & $\begin{array}{l}2.80 \\
2.90 \\
3.00 \\
3.00 \\
2.90 \\
2.90 \\
2.90 \\
2.90 \\
2.90 \\
2.90 \\
2.90 \\
3.00 \\
3.00 \\
3.00 \\
3.00 \\
3.00 \\
3.00 \\
3.00 \\
3.00 \\
3.00 \\
3.00 \\
3.00 \\
2.90 \\
3.70 \\
3.40 \\
3.30 \\
3.30 \\
3.20 \\
3.20 \\
3.10 \\
3.00\end{array}$ & $\begin{array}{r}3.00 \\
3.00 \\
3.00 \\
3.00 \\
2.90 \\
2.90 \\
3.00 \\
3.00 \\
3.00 \\
3.00 \\
2.90 \\
2.90 \\
2.90 \\
2.90 \\
3.00 \\
3.00 \\
3.00 \\
3.00 \\
3.00 \\
3.00 \\
3.00 \\
3.00 \\
3.10 \\
3.10 \\
4.00 \\
6.30 \\
11.60 \\
8.00 \\
5.70 \\
4.80\end{array}$ & $\begin{array}{l}4.40 \\
4.10 \\
3.90 \\
3.90 \\
5.50 \\
7.00 \\
6.30 \\
5.20 \\
4.60 \\
4.50 \\
4.30 \\
4.20 \\
4.00 \\
3.80 \\
3.70 \\
3.70 \\
3.60 \\
3.30 \\
3.50 \\
3.70 \\
3.80 \\
3.80 \\
3.60 \\
3.40 \\
3.80 \\
3.50 \\
3.30 \\
3.20 \\
3.20 \\
3.20 \\
3.20\end{array}$ \\
\hline
\end{tabular}

SUSQUEHANNA RIVER AT HARRISBURG, PENNSYLVANIA.

Gage-height observations were established at this station by E. Mather, president of the Harrisburg water board, in 1890. Discharge measurements were first made by $\mathbf{E}$. G. Paul on March 31, 1897, from the Walnut street bridge. The station is described in Water-Supply Paper No. 35, page 80 . The datum of this gage is the low-water mark of 1803 , which is recorded on a large rock above the bridge. During 1900 three measurements were made by Mr. Paul, as follows:

May 16: Gage height, 2.42 feet; discharge, 17,621 second-feet.

September 21: Gage height, 0.08 foot; discharge, 2,655 second-feet.

September 28: Gage height, -0.04 foot; discharge, 2,357 second-feet. 
Daily gage height, in feet, of Susquehanna River at Harrisburg, Pennsylvania, for 1900.

\begin{tabular}{|c|c|c|c|c|c|c|c|c|c|c|c|c|}
\hline Day. & Jan. & Feb. & Mar. & Apr. & May. & June. & July. & Aug. & Sept. & Oct. & Nov. & De \\
\hline . & $\begin{array}{r}1.83 \\
1.66 \\
4.50 \\
4.91 \\
4.83 \\
5.25 \\
5.50 \\
5.33 \\
4.91 \\
4.58 \\
4.50 \\
5.50 \\
4.91 \\
5.25 \\
5.25 \\
5.25 \\
4.66 \\
5.00 \\
4.83 \\
4.00 \\
4.25 \\
10.66 \\
12.00 \\
9.16 \\
7.25 \\
6.08 \\
5.00 \\
4.50 \\
4.08 \\
3.33 \\
2.50\end{array}$ & $\begin{array}{c}2.91 \\
1.83 \\
3.91 \\
4.00 \\
4.66 \\
4.33 \\
5.50 \\
5.00 \\
4.00 \\
4.83 \\
5.75 \\
5.50 \\
5.66 \\
7.66 \\
8.00 \\
8.25 \\
7.41 \\
6.00 \\
4.75 \\
3.91 \\
2.16 \\
3.58 \\
9.50 \\
1.16 \\
9.75 \\
6.83 \\
5.50 \\
4.50\end{array}$ & $\begin{array}{r}4.00 \\
13.12 \\
12.33 \\
9.50 \\
7.91 \\
6.91 \\
6.00 \\
6.16 \\
6.50 \\
5.83 \\
5.66 \\
6.25 \\
5.75 \\
4.66 \\
4.50 \\
4.00\end{array}$ & $\begin{array}{l}5.58 \\
5.00 \\
4.50 \\
4.33 \\
4.50 \\
4.41 \\
4.33 \\
5.08 \\
7.08 \\
7.33 \\
6.83 \\
6.08 \\
5.83 \\
6.00 \\
6.25 \\
5.75 \\
4.08 \\
4.17\end{array}$ & $\begin{array}{l}4.00 \\
3.75 \\
3.50 \\
3.33 \\
3.08 \\
2.83 \\
2.83 \\
2.75 \\
2.50 \\
2.50 \\
2.42 \\
2.33 \\
2.42 \\
2.42 \\
2.50 \\
2.40\end{array}$ & $\begin{array}{l}2.58 \\
2.50 \\
2.33 \\
2.17 \\
2.50 \\
2.67 \\
2.50 \\
2.17 \\
2.17 \\
2.08 \\
2.00 \\
2.00 \\
1.92 \\
1.92 \\
2.00 \\
2.17 \\
2.17 \\
2.00 \\
1.83 \\
1.83 \\
1.82 \\
1.75 \\
1.75 \\
1.58 \\
1.42 \\
1.33 \\
1.33 \\
1.33 \\
1.33 \\
1.17\end{array}$ & $\begin{array}{l}1.17 \\
1.08 \\
1.00 \\
1.08 \\
1.33 \\
1.17 \\
1.33 \\
1.17 \\
1.42 \\
1.42 \\
1.33 \\
1.17 \\
1.08 \\
1.08 \\
1.00 \\
1.00 \\
1.00 \\
1.08 \\
.92 \\
.92 \\
.83 \\
.75 \\
.75 \\
.75 \\
.75 \\
1.50 \\
1.25 \\
1.25 \\
1.42 \\
1.25\end{array}$ & $\begin{array}{r}1.25 \\
1.00 \\
1.00 \\
.92 \\
.75 \\
.67 \\
.67 \\
.58 \\
.50 \\
.58 \\
.50 \\
.33 \\
.33 \\
.25 \\
.17 \\
.17 \\
.15 \\
.17 \\
.17 \\
.33 \\
.42 \\
.83 \\
.50 \\
1.25 \\
1.00 \\
1.17 \\
1.50 \\
1.33 \\
1.00 \\
1.08\end{array}$ & $\begin{array}{r}1.00 \\
1.00 \\
. .83 \\
1.17 \\
.92 \\
.83 \\
.58 \\
.58 \\
.58 \\
.50 \\
.42 \\
.33 \\
.17 \\
.25 \\
.25 \\
. .25 \\
. .25 \\
.08 \\
.12 \\
.08 \\
.07 \\
.06 \\
.04 \\
.04 \\
.02 \\
-0.04 \\
-0.04 \\
0.04 \\
+0.04\end{array}$ & $\begin{array}{c}0.04 \\
.04 \\
.04 \\
.06 \\
.04 \\
.04 \\
.04 \\
.08 \\
.04 \\
.04 \\
.04 \\
.04 \\
.25 \\
.83 \\
.83 \\
.75 \\
.58 \\
.66 \\
.66 \\
.58 \\
.50 \\
.50 \\
.50 \\
.50 \\
1.00 \\
1.08 \\
1.00 \\
1.25 \\
1.16 \\
1.00 \\
.91\end{array}$ & $\begin{array}{r}0.83 \\
.83 \\
.75 \\
.75 \\
.75 \\
.66 \\
.66 \\
.66 \\
.75 \\
.58 \\
.66 \\
.50 \\
.58 \\
.75 \\
.66 \\
.66 \\
.83 \\
.91 \\
.75 \\
.91 \\
.91 \\
.91 \\
.83 \\
1.00 \\
1.08 \\
1.66 \\
5.91 \\
13.04 \\
12.33 \\
8.91\end{array}$ & 2. \\
\hline
\end{tabular}

MISCELLANEOUS DISCHARGE MEASUREMENTS IN PENNSYLVANIA.

During the year 1900 the following measurements of the Pennsylvanıa Canal and of Lehigh River were made by E. G. Paul:

Miscellaneous discharge measurements in Pennsylvania during 1900.

\begin{tabular}{|c|c|c|c|}
\hline Date. & Stream. & Locality. & Discharge. \\
\hline $\operatorname{Mav} 16$. & Pennsylyania Canal & Harrisburg & Sec.feet. \\
\hline May 18 & $\ldots$ do . . . . . . . . & .... do .... & 369 \\
\hline September 21. & .... do & .... do & 360 \\
\hline May $18 \ldots \ldots$ & ....do - & Steelton & 192 \\
\hline September 23 & .... do & . do do ..... & 161 \\
\hline May 18. & do & Highspire & 152 \\
\hline September 23 & - do & $-d o^{\circ}$ & 150 \\
\hline September 26 . & do & Nanticoke & 328 \\
\hline September 27 & Lehigh River & Easton, Glendon Bridge. & 303 \\
\hline
\end{tabular}


Daily gage height, in feet, of North Branch of Potomac River at Piedmont, West Virginia, for 1900 .

\begin{tabular}{c|c|c|c|c|c|c|c|c|c|c|c|c}
\hline Day. & Jan. & Feb. & Mar. & Apr. & May. & June. & July. & Aug. & Sept. & Oct. & Nov. & Dec. \\
\hline & & & & & & & & & & & & \\
\hline & & & & & & & \\
1
\end{tabular}

SOUTH BRANCH OF POTOMAC RIVER NEAR SPRINGFIELD, WEST VIRGINIA.

The station on the South Branch at Springfield was originally (April, 1894) established at the railroad bridge 2 miles south of that town, by C. C. Babb, but was discontinued in 1896 . The present station, which was established by E. G. Paul, January 26,1899 , is located on the iron highway bridge one-fourth of a mile from Grace Station and 1 mile from Springfield. It is described in Water-Supply Paper No. 35, page 85, where will also be found the gage heights and discharge measurement for 1899 . During 1900 the follewing measurements were made by Mr. Paul:

February 23: Gage height, 7.7 feet; discharge, 3,808 second-feet. June 20: Gage height, 7 feet; discharge, 3,435 second-feet. September 11: Gage height, 4 feet; discharge, 144 second-feet. 
Daily gage height, in feet, of South Branch of Potomac River near Springfield, West Virginia, for 1900.

\begin{tabular}{|c|c|c|c|c|c|c|c|c|c|c|c|c|}
\hline Day. & Jan. & Feb. & Mar. & Apr. & May. & June. & July. & Aug. & Sept. & Oct. & Nov. & Dec. \\
\hline 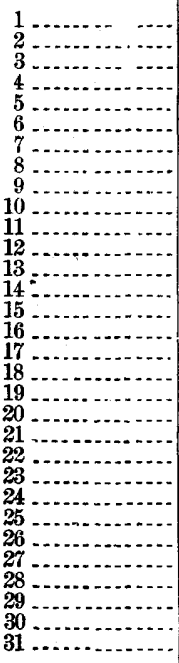 & $\begin{array}{c}(a) \\
(a) \\
(a) \\
(a) \\
(a) \\
(a) \\
(a) \\
(a) \\
(a) \\
(a) \\
(a) \\
(a) \\
(a) \\
(a) \\
(a) \\
4.2 \\
4.6 \\
4.8 \\
4.9 \\
5.0 \\
9.0 \\
7.0 \\
6.8 \\
6.2 \\
5.6 \\
5.2 \\
(a) \\
(a) \\
(a) \\
(a) \\
(a)\end{array}$ & $\begin{array}{c}(a) \\
(a) \\
(a) \\
(a) \\
(a) \\
(a) \\
(a) \\
(a) \\
(a) \\
5.8 \\
6.0 \\
6.4 \\
6.4 \\
6.8 \\
7.2 \\
7.0 \\
6.8 \\
(a) \\
(a) \\
(a) \\
(a) \\
6.4 \\
7.7 \\
7.4 \\
(a) \\
(a) \\
(a) \\
(a)\end{array}$ & $\begin{array}{r}9.8 \\
8.4 \\
6.8 \\
6.8 \\
6.4 \\
6.2 \\
7.0 \\
7.8 \\
9.4 \\
6.0 \\
7.4 \\
6.8 \\
6.2 \\
5.7 \\
5.4 \\
5.0 \\
4.8 \\
4.6 \\
5.0 \\
7.8 \\
11.4 \\
10.8 \\
9.2 \\
8.4 \\
7.6 \\
6.5 \\
6.4 \\
6.1 \\
6.8 \\
7.4 \\
7.8\end{array}$ & $\begin{array}{l}7.4 \\
7.0 \\
6.5 \\
5.6 \\
5.2 \\
5.2 \\
5.0 \\
5.0 \\
4.8 \\
4.6 \\
4.2 \\
4.2 \\
4.0 \\
4.0 \\
3.8 \\
3.5 \\
3.4 \\
3.4 \\
3.2 \\
4.4 \\
5.6 \\
6.0 \\
6.8 \\
6.2 \\
6.0 \\
5.6 \\
5.2 \\
5.0 \\
4.7 \\
4.4\end{array}$ & $\begin{array}{l}4.4 \\
4.3 \\
4.2 \\
4.2 \\
4.1 \\
4.1 \\
4.1 \\
4.0 \\
4.0 \\
4.0 \\
4.0 \\
3.9 \\
3.8 \\
3.8 \\
3.7 \\
3.6 \\
3.6 \\
3.6 \\
3.5 \\
4.0 \\
3.7 \\
3.5 \\
3.4 \\
3.4 \\
3.2 \\
3.1 \\
3.4 \\
3.4 \\
3.5 \\
3.6 \\
4.0\end{array}$ & $\begin{array}{r}4.0 \\
4.8 \\
4.4 \\
4.4 \\
4.2 \\
4.2 \\
4.1 \\
4.0 \\
4.0 \\
4.0 \\
3.9 \\
3.9 \\
3.9 \\
5.6 \\
5.2 \\
7.6 \\
13.0 \\
10.2 \\
9.5 \\
7.0 \\
5.4 \\
5.1 \\
5.0 \\
4.9 \\
4.9 \\
5.2 \\
5.4 \\
5.6 \\
5.6 \\
5.4\end{array}$ & $\begin{array}{l}5.0 \\
5.0 \\
5.0 \\
5.2 \\
5.2 \\
5.0 \\
5.0 \\
4.7 \\
4.4 \\
4.4 \\
4.2 \\
4.0 \\
3.6 \\
3.2 \\
3.2 \\
3.2 \\
3.1 \\
3.1 \\
3.0 \\
3.0 \\
3.0 \\
3.4 \\
3.6 \\
3.8 \\
3.8 \\
4.6 \\
5.0 \\
5.4 \\
5.4 \\
4.5 \\
4.0\end{array}$ & $\begin{array}{l}3.6 \\
3.4 \\
3.4 \\
3.4 \\
3.4 \\
3.2 \\
3.2 \\
3.2 \\
3.1 \\
3.0 \\
3.0 \\
3.0 \\
3.0 \\
3.0 \\
3.0 \\
2.9 \\
2.9 \\
2.9 \\
2.9 \\
2.9 \\
2.8 \\
3.2 \\
3.4 \\
3.4 \\
3.4 \\
4.2 \\
4.0 \\
4.0 \\
3.8 \\
3.6 \\
3.5\end{array}$ & $\begin{array}{l}3.5 \\
3.4 \\
3.4 \\
3.4 \\
3.3 \\
3.3 \\
3.2 \\
3.1 \\
3.8 \\
4.5 \\
4.0 \\
4.0 \\
3.6 \\
3.4 \\
3.0 \\
3.0 \\
2.9 \\
2.9 \\
2.9 \\
2.8 \\
2.8 \\
2.8 \\
3.0 \\
3.0 \\
3.0 \\
3.0 \\
3.0 \\
3.4 \\
3.5 \\
4.0\end{array}$ & $\begin{array}{l}4.0 \\
3.8 \\
3.7 \\
3.5 \\
3.4 \\
3.4 \\
3.6 \\
3.6 \\
3.5 \\
3.5 \\
3.5 \\
3.3 \\
3.2 \\
3.2 \\
3.8 \\
3.7 \\
3.6 \\
3.6 \\
3.6 \\
3.5 \\
3.5 \\
3.5 \\
3.5 \\
3.4 \\
3.2 \\
3.2 \\
3.2 \\
3.2 \\
3.4 \\
3.5\end{array}$ & $\begin{array}{r}3.6 \\
3.6 \\
3.6 \\
4.0 \\
4.0 \\
3.8 \\
3.8 \\
3.6 \\
3.6 \\
3.6 \\
3.5 \\
3.4 \\
3.8 \\
3.2 \\
3.2 \\
3.1 \\
3.1 \\
3.1 \\
3.4 \\
3.4 \\
3.6 \\
3.8 \\
3.8 \\
3.8 \\
4.0 \\
10.2 \\
1.0 \\
9.0 \\
8.2 \\
6.8\end{array}$ & $\begin{array}{r}5.2 \\
5.0 \\
5.0 \\
5.0 \\
5.9 \\
10.6 \\
12.0 \\
10.0 \\
5.0 \\
5.0 \\
4.8 \\
4.7 \\
4.7 \\
4.5 \\
4.5 \\
4.4 \\
(a) \\
(a) \\
(a) \\
4.2 \\
4.0 \\
4.0 \\
3.8 \\
3.7 \\
3.7 \\
3.6 \\
3.5 \\
3.5 \\
3.5 \\
3.4 \\
3.4\end{array}$ \\
\hline
\end{tabular}

$a$ Ice.

\section{ANTIETAM CREEK NEAR SHARPSBURG, MARYLAND.}

This station was established at Myers's mill, 1 mile east of Sharpsburg, Maryland, on the road to Keedysville, Maryland, on June 24, 1897, by Arthur P. Davis. It is described in Water-Supply-Paper No. 35 , page 86 , where will be found the gage heights for 1899 . Records of discharge measurements for the year 1899 will be found in the Twenty-first Annual Report, Part IV, page 95. During 1900 the following measurements were made by E. G. Paul:

June 28: Gage height, 1.80 feet; discharge, 139 second-feet.

September 16: Gage height, 1.75 feet; discharge, 131 second-feet.

IRR $48-01-2$ 
Daily gage height, in feet, of Antietam Creek near Sharpsburg, Maryland, for 1900.

\begin{tabular}{|c|c|c|c|c|c|c|c|c|c|c|c|c|}
\hline Da & Jan. & Feb. & Mar. & Apr. & May. & June. & July. & Ang. & Sept. & Oet. & Nov: & Dec." \\
\hline $\begin{array}{r}1 \\
1 \\
3 \\
3\end{array}$ & $\begin{array}{l}1.50 \\
1.50 \\
1.50 \\
1.60 \\
1.60 \\
1.70 \\
1.70 \\
1.80 \\
1.90 \\
1.80 \\
1.80 \\
1.80 \\
1.70 \\
1.70 \\
1.80 \\
1.70 \\
1.70 \\
1.70 \\
1.80 \\
2.10 \\
2.50 \\
2.00 \\
1.90 \\
1.80 \\
1.70 \\
2.30 \\
2.20 \\
2.00 \\
1.80 \\
1.60 \\
1.60\end{array}$ & \begin{tabular}{|}
1.60 \\
1.70 \\
1.60 \\
1.50 \\
1.50 \\
1.60 \\
1.50 \\
2.00 \\
2.20 \\
2.00 \\
1.90 \\
2.00 \\
2.70 \\
2.70 \\
2.40 \\
2.40 \\
2.20 \\
2.10 \\
2.20 \\
2.20 \\
2.30 \\
4.15 \\
3.75 \\
3.05 \\
3.80 \\
3.30 \\
3.00 \\
3.00 \\
$\cdots \therefore . .$. \\
$\cdots \ldots .$. \\
$\cdots \ldots . .$.
\end{tabular} & $\begin{array}{l}3.80 \\
3.60 \\
3.00 \\
2.80 \\
2.70 \\
2.70 \\
2.75 \\
2.60 \\
2.50 \\
2.50 \\
2.50 \\
2.50 \\
2.40 \\
2.40 \\
2.40 \\
2.40 \\
2.30 \\
2.25 \\
2.40 \\
2.90 \\
3.10 \\
2.80 \\
2.70 \\
2.70 \\
2.60 \\
2.50 \\
2.60 \\
2.50 \\
2.50 \\
2.60 \\
2.60\end{array}$ & $\begin{array}{l}2.50 \\
2.50 \\
2.40 \\
2.30 \\
2.30 \\
2.30 \\
2.40 \\
2.30 \\
2.30 \\
2.20 \\
2.20 \\
2.30 \\
2.30 \\
2.30 \\
2.20 \\
2.30 \\
2.20 \\
2.30 \\
2.35 \\
2.30 \\
2.70 \\
2.30 \\
2.40 \\
2.30 \\
2.20 \\
2.20 \\
2.10 \\
2.10 \\
2.10 \\
2.00 \\
-\ldots . . .\end{array}$ & $\begin{array}{l}2.10 \\
2.10 \\
2.00 \\
2.10 \\
2.00 \\
1.90 \\
2.10 \\
2.00 \\
2.00 \\
1.90 \\
1.80 \\
1.90 \\
1.80 \\
1.80 \\
2.00 \\
1.90 \\
2.00 \\
2.00 \\
2.40 \\
3.10 \\
2.10 \\
2.20 \\
2.10 \\
2.10 \\
2.10 \\
2.00 \\
1.90 \\
1.90 \\
2.00 \\
1.90 \\
2.10\end{array}$ & $\begin{array}{l}2.00 \\
1.90 \\
1.90 \\
2.00 \\
1.90 \\
1.90 \\
1.90 \\
1.90 \\
1.90 \\
1.70 \\
2.00 \\
1.90 \\
1.80 \\
1.70 \\
1.70 \\
1.85 \\
2.10 \\
2.20 \\
2.55 \\
2.10 \\
2.00 \\
1.90 \\
1.80 \\
1.70 \\
1.80 \\
1.80 \\
1.90 \\
1.80 \\
1.80 \\
1.70 \\
\cdots \cdots . . .\end{array}$ & $\begin{array}{l}1.70 \\
1.70 \\
1.60 \\
1.50 \\
1.70 \\
1.70 \\
1.60 \\
1.60 \\
1.70 \\
1.60 \\
1.50 \\
1.55 \\
1.50 \\
1.55 \\
1.60 \\
1.45 \\
1.50 \\
1.50 \\
1.50 \\
1.60 \\
1.50 \\
1.40 \\
1.90 \\
1.85 \\
1.65 \\
2.00 \\
1.90 \\
1.80 \\
1.55 \\
1.40 \\
1.40\end{array}$ & $\begin{array}{l}1.40 \\
1.40 \\
1.50 \\
1.50 \\
1.40 \\
1.40 \\
1.40 \\
1.40 \\
1.45 \\
1.50 \\
1.40 \\
1.50 \\
1.50 \\
1.40 \\
1.70 \\
1.60 \\
1.60 \\
1.60 \\
1.60 \\
1.70 \\
1.80 \\
1.80 \\
1.70 \\
1.70 \\
1.80 \\
1.70 \\
1.70 \\
2.00 \\
1.90 \\
1.80 \\
1.70\end{array}$ & $\begin{array}{l}1.60 \\
1.60 \\
1.40 \\
1.60 \\
1.70 \\
1.60 \\
1.50 \\
1.50 \\
1.40 \\
1.40 \\
1.40 \\
1.40 \\
1.50 \\
1.60 \\
1.60 \\
1.80 \\
1.100 \\
1.50 \\
1.50 \\
1.50 \\
1.40 \\
1.30 \\
1.40 \\
1.40 \\
1.40 \\
1.40 \\
1.40 \\
1.50 \\
1.60\end{array}$ & $\begin{array}{l}1.40 \\
1.50 \\
1.40 \\
1.40 \\
1.50 \\
1.40 \\
1.40 \\
1.30 \\
1.50 \\
1.60 \\
1.60 \\
1.50 \\
1.50 \\
2.05 \\
1.90 \\
1.70 \\
1.60 \\
1.40 \\
1.60 \\
1.60 \\
1.40 \\
1.50 \\
1.50 \\
1.80 \\
1.70 \\
1.50 \\
1.50 \\
1.40 \\
1.30 \\
1.40 \\
1.60\end{array}$ & $\begin{array}{l}1.70 \\
1.50 \\
1.50 \\
1.50 \\
1.50 \\
1.40 \\
1.50 \\
1.60 \\
1.60 \\
1.60 \\
1.50 \\
1.40 \\
1.70 \\
1.50 \\
1.70 \\
1.50 \\
1.50 \\
1.40 \\
1.50 \\
1.50 \\
1.60 \\
1.50 \\
1.50 \\
1.50 \\
1.50 \\
2.50 \\
2.10 \\
1.80 \\
1.70 \\
1.60\end{array}$ & $\begin{array}{l}1.55 \\
1.55 \\
1.50 \\
2.30 \\
2.40 \\
2.00 \\
1.60 \\
1.70 \\
1.70 \\
1.60 \\
1.60 \\
1.50 \\
1.50 \\
1.50 \\
1.40 \\
1.30 \\
1.50 \\
1.40 \\
1.50 \\
1.50 \\
1.50 \\
1.50 \\
1.50 \\
1.40 \\
1.30 \\
1.60 \\
1.50 \\
1.50 \\
1.50 \\
1.40 \\
1.50\end{array}$ \\
\hline
\end{tabular}

NORTH AND SOUTH RIVERS AT PORT REPUBLIC, VIRGINIA.

These stations were established in August, 1895. They are described in Water-Supply Paper No. 35, page 86, where records of past measurements will be found. Both stations were discontinued on April 1, 1899.

\section{NORTH BRANCH OF SHENANDOAH RIVER NEAR RIVERTON, VIRGINIA.}

This station, which was established June 26, 1899, by Arthur P. Davis, is about 2 miles northwest of Riverton. It is described in Water-Supply Paper No. 35, page 88, where will be found records of discharge measurements made during 1899. During 1900 the following measurements were made by E. G. Paul:

February 13: Gage height, 3.25 feet; discharge, 645 second-feet. June 18: Gage height, 5.30 feet; discharge, 2,923 second-feet. September 10: Gage height, 2.60 feet; discharge, 146 second-feet. 
Daily gage height, in feet, of North Branch of Shenandoah River near Riverton, Virginia, for 1900.

\begin{tabular}{c|c|c|c|c|c|c|c|c|c|c|c|c}
\hline Day. & Jan. & Feb. & Mar. & Apr. & May. & June. & July. & Aug. & Sept. & Oct. & Nov. & Dec. \\
\hline & & & & & & & \\
\hline & & & & & & & & \\
\hline
\end{tabular}

SOUTH BRANCH OF SHENANDOAH RIVER AT FRONT ROYAL, VIRGINIA.

This station was established by Arthur P. Davis on June 26, 1899. It is described in Water-Supply Paper No. 35, page 89, where will also be found record of discharge measurement made in 1899. During 1900 the following measurements were made by E. G. Paul:

February 14: Gage height, 5.75 feet: discharge, 1,955 second-feet. June 19: Gage beight, 7.90 feet; discharge, 5,703 second-feet. 
Daily gage height, in feet, of South Branch of Shenandoah River at Front Royal, Virginia, for 1900 .

\begin{tabular}{r|r|r|r|r|r|r|r|r|r|r|r|r}
\hline Day. & Jan. & Feb. & Mar. & Apr. & May. & June. & July. & Aug. & Sept. & Oct. & Nov. & Dec. \\
\hline & & & & & & & \\
& & & & & & & \\
\hline
\end{tabular}

SHENANDOAH RIVER AT MILLVILLE, WEST VIRGINIA.

This station, which was established April 15, 1895, is 4 miles above the mouth of Shenandoah River. It is described in Water-Supply Paper No. 35, pages 90 and 91. Records of measurements for 1899 will be found in the Twenty-first Annual Report, Part IV, page 96. During 1900 the following measurements were made by E. G. Paul:

February 24: Gage height, 5.9 feet; discharge, 12,985 second-feet.

June 19: Gage height, 4.5 feet; discharge, 9,132 second-feet.

September 15: Gage height, 0.4 foot; discharge, 500 second-feet. 
Daily gage height, in feet, of Shenandoah River at Millville, West Virginia, for 1900.

\begin{tabular}{r|r|r|r|r|r|r|r|r|r|r|r|r}
\hline Day. & Jan. & Feb. & Mar. & Apr. & May. & June. & July. & Aug. & Sept. & Oct. & Nov. & Dec. \\
\hline & & & & & & & \\
\hline & & & & & & & \\
\hline
\end{tabular}

POTOMAC RIVER AT POINT OF ROCKS, MARYLAND.

This station was established February 17, 1895, at the tollbridge over the Potomac River at Point of Rocks. It has been described and results of measurements have been given in the various Annual Reports and in the Water-Supply and Irrigation Papers containing reports of the operations at river stations. More or less difficulty has been experienced with the wire gage, due to its stretching, and no record of this lengthening has been noted. A thorough study of the changes of the gage have been made in this office, based on measurements and on a study of the average depth of soundings, with the result that it has been found necessary to modify the gage heights in order to refer them to a common datum. This has also necessitated a revision of the rating table. In some cases it has been impossible to reduce the measurements to the known datum, and it has therefore been thought best to discard them and to publish here only such gage heights and discharge measurements as could be reduced to a common datum and on which reliance can be placed as giving a correct estimate of the discharge.

As originally placed the gage was located in the third span of the bridge from the north shore. The next year (1896) the wire became rusted and broke frequently, and a new wire gage was placed in the east side of the first span of the bridge, but it was referred to a different datum. During 1897 there was a further change in the length 
of the gage, which was not recorded, and therefore it has been necessary to discard the records during those two years-that is, 1896 and 1897.

On January 25, 1898, the gage wire was compared with the bench mark, and the observations since that date have been referred to this datum. The bench mark to which the gage has been referred is a copper bolt in a large capstone on the lower wing wall of the north abutment, about 10 feet from the north end of the first iron truss and 41.30 feet above the datum of the gage. The length of the cable of the wire gage is 44.22 feet. The measurements of 1895 are considered correct within themselves, but there was a difference between the datum of that gage and that of the present standard of 0.4 foot, making it necessary to deduct that amount from the gage readings of 1895 in order to reduce them to the present datum. Tables of the corrected gage heights and of the discharge measurements computed from them are published herewith.

The flood discharge of February 23, 1897, is also considered correct, and is given in the table of discharge measurements. There is no change in the published discharge measurements or the gage heights for 1898,1899 , and 1900 , but they are reproduced here in order to bring together all of the records that could be reduced to one standard.

Discharge measurements of Potomac River at Point of Rocks, Maryland.

\begin{tabular}{|c|c|c|c|c|c|}
\hline Date. & $\begin{array}{c}\text { Gage } \\
\text { height. }\end{array}$ & Discharge. & Date. & $\begin{array}{c}\text { Gage } \\
\text { height. }\end{array}$ & Discharge. \\
\hline 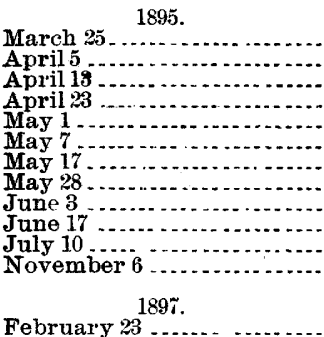 & $\begin{array}{r}\text { Feet. } \\
3.05 \\
3.42 \\
4.27 \\
2.10 \\
4.35 \\
3.10 \\
2.35 \\
2.45 \\
1.53 \\
1.30 \\
1.50 \\
.40 \\
\\
21.70\end{array}$ & $\begin{array}{r}\text { Sec.-ft. } \\
10,524 \\
14,032 \\
17,516 \\
7,371 \\
21,073 \\
12,484 \\
8,918 \\
9,189 \\
4,536 \\
4,233 \\
4,695 \\
1,202\end{array}$ & 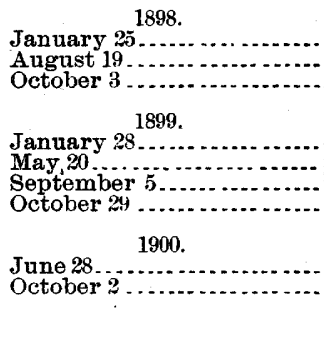 & $\begin{array}{r}\text { Feet. } \\
6.50 \\
3.30 \\
.65 \\
\\
3.80 \\
8.15 \\
.80 \\
.50\end{array}$ & $\begin{array}{r}\text { Sec. } f t . \\
33,344 \\
14,309 \\
1,939 \\
\\
17,330 \\
45,986 \\
2,360 \\
1,628\end{array}$ \\
\hline
\end{tabular}


Daily gage height, in feet, of Potomac River at Point of Rocks, Maryland, for 1895 .

\begin{tabular}{|c|c|c|c|c|c|c|c|c|c|c|c|}
\hline Day. & Feb. & Mar. & Apr. & May. & June. & July. & Aug. & Sept. & Oct. & Nor. & Dec. \\
\hline $\begin{array}{r}1 \\
2 \\
3 \\
4\end{array}$ & $\begin{array}{l}1.60 \\
1.60 \\
1.60 \\
1.60 \\
1.70 \\
1.80 \\
2.00 \\
\mathbf{2 . 0 0} \\
\boldsymbol{2 . 0 0} \\
\mathbf{2 . 1 0} \\
\mathbf{2 . 9 0} \\
\mathbf{3 . 6 0}\end{array}$ & $\begin{array}{r}6.10 \\
9.70 \\
10.60 \\
9.60 \\
7.10 \\
5.60 \\
4.80 \\
4.30 \\
4.10 \\
4.10 \\
4.00 \\
3.60 \\
3.60 \\
3.60 \\
4.70 \\
5.90 \\
8.10 \\
6.90 \\
5.40 \\
4.90 \\
4.10 \\
3.80 \\
3.40 \\
3.20 \\
3.00 \\
2.90 \\
3.06 \\
3.80 \\
3.20 \\
4.30 \\
3.50\end{array}$ & $\begin{array}{r}3.10 \\
3.00 \\
2.90 \\
3.60 \\
3.50 \\
3.00 \\
2.70 \\
2.60 \\
3.00 \\
10.80 \\
7.90 \\
5.80 \\
4.50 \\
3.80 \\
.3 .50 \\
3.40 \\
3.30 \\
3.00 \\
2.70 \\
2.60 \\
2.40 \\
2.20 \\
2.10 \\
2.00 \\
2.00 \\
1.90 \\
1.80 \\
1.80 \\
1.80 \\
2.20\end{array}$ & $\begin{array}{l}3.30 \\
5.90 \\
5.80 \\
5.49 \\
4.40 \\
3.70 \\
3.10 \\
2.70 \\
2.70 \\
2.80 \\
2.80 \\
2.70 \\
2.70 \\
2.80 \\
3.00 \\
2.60 \\
2.40 \\
2.20 \\
2.20 \\
2.40 \\
2.30 \\
2.40 \\
2.80 \\
3.80 \\
3.30 \\
2.60 \\
2.50 \\
2.40 \\
2.40 \\
2.20 \\
2.00\end{array}$ & $\begin{array}{l}1.80 \\
1.70 \\
1.50 \\
1.40 \\
1.40 \\
1.40 \\
1.20 \\
.80 \\
1.30 \\
1.20 \\
1.10 \\
1.10 \\
1.20 \\
1.20 \\
1.50 \\
1.30 \\
1.20 \\
1.10 \\
1.10 \\
1.00 \\
.90 \\
1.00 \\
1.00 \\
.90 \\
.80 \\
.80 \\
1.20 \\
2.10 \\
1.60 \\
1.50\end{array}$ & $\begin{array}{l}2.00 \\
2.70 \\
.30 \\
2.10 \\
1.90 \\
1.70 \\
1.50 \\
1.50 \\
1.70 \\
1.60 \\
1.50 \\
1.50 \\
1.30 \\
1.20 \\
1.10 \\
1.00 \\
1.00 \\
1.00 \\
1.10 \\
1.00 \\
1.00 \\
1.00 \\
1.10 \\
.90 \\
.90 \\
1.00 \\
1.20 \\
1.30 \\
1.10 \\
1.10\end{array}$ & $\begin{array}{r}1.00 \\
.90 \\
.80 \\
.80 \\
.90 \\
.80 \\
.80 \\
.80 \\
1.10 \\
1.00 \\
.90 \\
.80 \\
.80 \\
.70 \\
.70 \\
.60 \\
.60 \\
.60 \\
.60 \\
.60 \\
.60 \\
.50 \\
.50 \\
.50 \\
.40 \\
.40 \\
.40 \\
.40 \\
.40 \\
.50 \\
.50\end{array}$ & $\begin{array}{r}0.60 \\
.70 \\
.90 \\
.70 \\
.60 \\
.60 \\
.60 \\
.50 \\
.50 \\
.60 \\
.50 \\
.50 \\
.50 \\
.50 \\
.50 \\
.50 \\
.40 \\
.40 \\
.50 \\
.50 \\
.40 \\
.40 \\
.40 \\
.50 \\
.50 \\
.40 \\
.40 \\
.40 \\
.30 \\
.30\end{array}$ & $\begin{array}{l}0.30 \\
.30 \\
.30 \\
.30 \\
.30 \\
.30 \\
.30 \\
.30 \\
.30 \\
.30 \\
.30 \\
.40 \\
.20 \\
.20 \\
.30 \\
.30 \\
.30 \\
.30 \\
.30 \\
.30 \\
.20 \\
.20 \\
.30 \\
.30 \\
.30 \\
.30 \\
.30 \\
.30 \\
.30 \\
.30 \\
.30\end{array}$ & $\begin{array}{l}0.40 \\
.40 \\
.30 \\
.30 \\
.30 \\
.40 \\
.30 \\
.30 \\
.30 \\
.40 \\
.40 \\
.50 \\
.40 \\
.40 \\
.40 \\
.40 \\
.40 \\
.40 \\
.40 \\
.40 \\
.40 \\
.40 \\
.40 \\
.40 \\
.40 \\
.40 \\
.40 \\
.50 \\
.50 \\
.40\end{array}$ & $\begin{array}{r}0.40 \\
.50 \\
.50 \\
.50 \\
.50 \\
.60 \\
.80 \\
.80 \\
.60 \\
.50 \\
.50 \\
.50 \\
.60 \\
1.60 \\
.60 \\
.50 \\
.40 \\
.40 \\
.30 \\
.30 \\
.30 \\
.60 \\
.60 \\
1.30 \\
1.30 \\
1.20 \\
1.30 \\
1.40 \\
.90 \\
.90 \\
.30\end{array}$ \\
\hline
\end{tabular}

Daily gage height, in feet, of Potomac River at Point of Rocks, Maryland, for 1898.

\begin{tabular}{|c|c|c|c|c|c|c|c|c|c|c|c|c|}
\hline & an. & Feb. & Iar. & Apr. & May. & June. & July. & Aug. & Sept. & Oct. & Nov. & Dec. \\
\hline 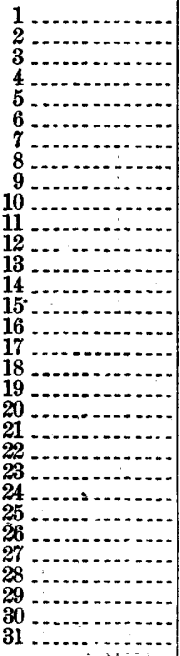 & $\begin{array}{l}2.90 \\
2.90 \\
3.00 \\
3.20 \\
3.20 \\
3.30 \\
3.20 \\
2.90 \\
3.00 \\
3.20 \\
3.90 \\
5.80 \\
5.70 \\
5.30 \\
5.50 \\
6.70 \\
8.00 \\
6.70 \\
5.60 \\
4.90 \\
4.70 \\
4.60 \\
5.00 \\
9.40 \\
8.40 \\
5.10 \\
5.00 \\
5.10 \\
5.10 \\
3.60 \\
3.40\end{array}$ & $\begin{array}{l}2.80 \\
1.70 \\
2.00 \\
1.90 \\
1.90 \\
2.00 \\
2.00 \\
1.90 \\
1.90 \\
1.80 \\
1.80 \\
1.90 \\
2.00 \\
1.90 \\
1.90 \\
2.00 \\
2.00 \\
1.80 \\
1.70 \\
1.70 \\
2.80 \\
3.80 \\
4.10 \\
3.40 \\
2.90 \\
2.60 \\
2.30 \\
2.10 \\
\ldots \ldots . . \\
\ldots . . .\end{array}$ & $\begin{array}{r}1.90 \\
1.80 \\
1.70 \\
1.70 \\
1.60 \\
1.60 \\
1.60 \\
1.50 \\
1.50 \\
1.40 \\
1.40 \\
1.50 \\
1.50 \\
1.60 \\
1.60 \\
1.70 \\
1.70 \\
2.00 \\
\mathbf{5 . 8 0} \\
4.60 \\
3.50 \\
3.50 \\
6.60 \\
6.20 \\
6.40 \\
10.50 \\
7.20 \\
\mathbf{5 . 3 0} \\
4.40 \\
4.30 \\
6.20\end{array}$ & $\begin{array}{r}6.10 \\
5.20 \\
4.60 \\
4.10 \\
3.80 \\
3.60 \\
3.20 \\
2.90 \\
2.40 \\
2.50 \\
2.50 \\
2.40 \\
2.40 \\
2.50 \\
2.50 \\
4.00 \\
9.00 \\
6.70 \\
5.10 \\
4.20 \\
3.50 \\
3.20 \\
2.90 \\
2.60 \\
2.60 \\
2.60 \\
.2 .50 \\
3.30 \\
3.00 \\
2.80\end{array}$ & $\begin{array}{r}2.60 \\
2.40 \\
2.20 \\
2.00 \\
1.90 \\
1.80 \\
2.20 \\
5.40 \\
11.05 \\
9.60 \\
6.50 \\
5.20 \\
4.20 \\
3.70 \\
3.10 \\
3.00 \\
3.20 \\
4.60 \\
4.40 \\
3.50 \\
2.30 \\
2.90 \\
3.10 \\
3.90 \\
5.10 \\
5.60 \\
4.10 \\
3.40 \\
3.00 \\
2.80 \\
2.40\end{array}$ & $\begin{array}{l}2.20 \\
2.00 \\
1.80 \\
1.70 \\
1.60 \\
1.40 \\
1.30 \\
1.30 \\
1.20 \\
1.20 \\
1.10 \\
1.10 \\
1.10 \\
1.30 \\
1.30 \\
1.30 \\
1.30 \\
1.20 \\
1.50 \\
1.40 \\
1.30 \\
1.30 \\
1.30 \\
1.20 \\
1.10 \\
1.10 \\
1.00 \\
1.00 \\
.90 \\
.90 \\
\cdots \ldots\end{array}$ & $\begin{array}{l}0.90 \\
.80 \\
.80 \\
.70 \\
.70 \\
.70 \\
.70 \\
.80 \\
.70 \\
.70 \\
.70 \\
.60 \\
.50 \\
.50 \\
.50 \\
.50 \\
.50 \\
.50 \\
.70 \\
.70 \\
.90 \\
.90 \\
1.10 \\
.90 \\
.80 \\
.90 \\
1.20 \\
1.00 \\
1.20 \\
1.40 \\
1.70\end{array}$ & $\begin{array}{r}1.50 \\
1.70 \\
1.40 \\
1.20 \\
2.20 \\
7.20 \\
6.10 \\
3.70 \\
3.90 \\
5.60 \\
14.00 \\
16.05 \\
9.50 \\
8.00 \\
7.20 \\
6.10 \\
5.20 \\
4.30 \\
3.30 \\
3.10 \\
3.00 \\
3.80 \\
2.80 \\
2.30 \\
2.00 \\
1.80 \\
1.50 \\
1.50 \\
1.40 \\
1.30 \\
1.30\end{array}$ & $\begin{array}{r}1.20 \\
1.10 \\
1.10 \\
1.00 \\
1.00 \\
1.00 \\
1.00 \\
1.00 \\
1.00 \\
.90 \\
.90 \\
.90 \\
.80 \\
.80 \\
.80 \\
.80 \\
.80 \\
.80 \\
.80 \\
.70 \\
.70 \\
.70 \\
.70 \\
.70 \\
.70 \\
.70 \\
.90 \\
.80 \\
.70 \\
.70\end{array}$ & $\begin{array}{r}0.70 \\
.70 \\
.60 \\
.70 \\
.80 \\
.80 \\
1.00 \\
1.10 \\
1.00 \\
1.00 \\
.90 \\
.90 \\
1.40 \\
1.20 \\
1.00 \\
.80 \\
.80 \\
.80 \\
1.40 \\
9.00 \\
5.40 \\
5.35 \\
13.10 \\
10.10 \\
5.90 \\
4.50 \\
3.80 \\
3.60 \\
3.40 \\
3.00 \\
2.80\end{array}$ & $\begin{array}{l}2.70 \\
2.50 \\
2.30 \\
2.20 \\
2.00 \\
1.80 \\
1.80 \\
1.70 \\
1.60 \\
1.60 \\
2.00 \\
1.80 \\
1.80 \\
2.00 \\
2.00 \\
1.80 \\
1.80 \\
1.80 \\
2.20 \\
3.00 \\
3.60 \\
3.30 \\
3.20 \\
3.10 \\
3.00 \\
2.70 \\
2.60 \\
2.40 \\
2.20 \\
2.10 \\
\end{array}$ & $\begin{array}{l}2.10 \\
2.10 \\
2.00 \\
2.50 \\
5.10 \\
9.20 \\
6.10 \\
4.50 \\
3.60 \\
3.00 \\
2.60 \\
2.40 \\
2.20 \\
2.20 \\
2.00 \\
1.80 \\
1.80 \\
2.00 \\
2.10 \\
2.20 \\
2.60 \\
3.30 \\
4.70 \\
6.20 \\
6.90 \\
5.30 \\
4.30 \\
3.70 \\
3.20 \\
3.00 \\
2.70\end{array}$ \\
\hline
\end{tabular}


Daily gage height, in feet, of Potomac River at Point of Rocks, Maryland, for 1899.

\begin{tabular}{r|r|r|r|r|r|r|r|r|r|r|r|r}
\hline Day. & Jan. & Feb. & Mar. & Apr. & May. & June. & July. & Aug. & Sept. & Oct. & Nov. & Dec. \\
\hline & & & & & & & \\
\hline & & & & & & & \\
\hline
\end{tabular}

Daily gage height, in feet, of Potomac River at Point of Rocks, Maryland, for 1900.

\begin{tabular}{|c|c|c|c|c|c|c|c|c|c|c|c|c|}
\hline Day. & Jan. & Feb. & Mar. & Apr. & May. & June. & July. & Atug. & Sept. & Oct. & Nov. & Dec. \\
\hline $\begin{array}{r}1 \\
2 \\
3\end{array} 4 \ldots$ & $\begin{array}{l}1.50 \\
1.50 \\
1.40 \\
1.50 \\
1.50 \\
1.40 \\
1.40 \\
1.30 \\
1.30 \\
1.20 \\
1.30 \\
1.40 \\
1.40 \\
1.50 \\
1.80 \\
2.10 \\
1.90 \\
1.70 \\
1.60 \\
2.20 \\
3.60 \\
6.80 \\
5.50 \\
4.00 \\
. .30 \\
2.80 \\
2.50 \\
2.10 \\
1.80 \\
1.30 \\
1.20\end{array}$ & $\begin{array}{l}1.00 \\
1.60 \\
2.00 \\
2.10 \\
2.20 \\
1.90 \\
1.80 \\
1.50 \\
1.80 \\
2.30 \\
3.00 \\
2.50 \\
3.00 \\
4.50 \\
5.30 \\
4.50 \\
3.80 \\
3.10 \\
2.60 \\
2.30 \\
1.90 \\
3.00 \\
6.90 \\
7.10 \\
5.60 \\
3.90 \\
3.30 \\
3.00\end{array}$ & 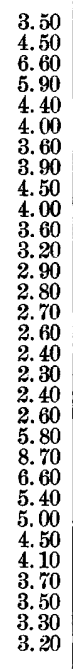 & $\begin{array}{l}4.80 \\
3.80 \\
3.40 \\
3.10 \\
2.80 \\
2.70 \\
2.60 \\
2.50 \\
2.40 \\
2.30 \\
2.10 \\
2.10 \\
2.00 \\
1.90 \\
1.90 \\
1.80 \\
1.80 \\
1.70 \\
1.70 \\
1.60 \\
1.70 \\
2.20 \\
2.50 \\
2.80 \\
3.00 \\
2.80 \\
2.50 \\
2.30 \\
2.10 \\
2.00\end{array}$ & $\begin{array}{l}1.90 \\
1.70 \\
1.60 \\
1.50 \\
1.50 \\
1.40 \\
1.40 \\
1.30 \\
1.30 \\
1.30 \\
1.20 \\
1.20 \\
1.10 \\
1.10 \\
1.10 \\
1.10 \\
1.00 \\
1.00 \\
1.20 \\
1.30 \\
1.80 \\
1.90 \\
2.00 \\
1.70 \\
1.50 \\
1.40 \\
1.40 \\
1.40 \\
1.30 \\
1.20 \\
1.30\end{array}$ & $\begin{array}{l}1.30 \\
1.30 \\
1.30 \\
1.40 \\
1.60 \\
1.60 \\
1.50 \\
1.40 \\
1.40 \\
1.30 \\
1.20 \\
1.10 \\
1.00 \\
.90 \\
1.30 \\
1.00 \\
1.80 \\
2.80 \\
8.50 \\
6.20 \\
4.60 \\
3.60 \\
2.70 \\
2.30 \\
2.10 \\
2.00 \\
1.80 \\
1.50 \\
1.40 \\
1.30 \\
\cdots \cdots\end{array}$ & $\begin{array}{r}1.20 \\
1.10 \\
1.00 \\
1.00 \\
.90 \\
1.30 \\
1.00 \\
.90 \\
.80 \\
.70 \\
.60 \\
.60 \\
.50 \\
.50 \\
.50 \\
.40 \\
.40 \\
.40 \\
.50 \\
1.40 \\
1.00 \\
.90 \\
.80 \\
1.80 \\
1.60 \\
2.00 \\
1.40 \\
1.20 \\
1.00 \\
1.30 \\
1.30\end{array}$ & $\begin{array}{r}1.20 \\
1.10 \\
1.00 \\
.90 \\
.90 \\
.80 \\
.80 \\
.70 \\
.60 \\
.60 \\
.50 \\
.50 \\
.40 \\
.40 \\
.40 \\
.40 \\
.40 \\
.40 \\
.40 \\
.40 \\
.40 \\
.40 \\
.40 \\
.40 \\
.50 \\
.60 \\
.70 \\
.90 \\
.90 \\
.80 \\
.80\end{array}$ & $\begin{array}{r}0.70 \\
.70 \\
.60 \\
.60 \\
.50 \\
.60 \\
.50 \\
.40 \\
.40 \\
.30 \\
.40 \\
.30 \\
.30 \\
.40 \\
.40 \\
.40 \\
.30 \\
.30 \\
.30 \\
.30 \\
.30 \\
.30 \\
.30 \\
.30 \\
.30 \\
.30 \\
.30 \\
.20 \\
.30 \\
.30\end{array}$ & $\begin{array}{r}0.30 \\
.30 \\
.30 \\
.30 \\
.30 \\
.30 \\
.30 \\
.30 \\
.30 \\
.30 \\
.30 \\
.30 \\
.30 \\
.30 \\
.90 \\
.50 \\
.40 \\
.40 \\
.30 \\
.30 \\
.30 \\
.50 \\
.40 \\
.40 \\
.40 \\
.40 \\
.50 \\
.50 \\
.50 \\
.50 \\
.50\end{array}$ & $\begin{array}{r}0.50 \\
.50 \\
.50 \\
.50 \\
.50 \\
.40 \\
.40 \\
.40 \\
.50 \\
.60 \\
.50 \\
.40 \\
.40 \\
.40 \\
.40 \\
.40 \\
.40 \\
.30 \\
.20 \\
.20 \\
.30 \\
.40 \\
.40 \\
.40 \\
.40 \\
1.20 \\
3.30 \\
8.20 \\
5.40 \\
3.20 \\
\cdots . . .\end{array}$ & $\begin{array}{r}2.40 \\
1.90 \\
1.60 \\
1.60 \\
2.00 \\
4.10 \\
5.90 \\
3.70 \\
3.00 \\
2.50 \\
2.10 \\
1.80 \\
1.60 \\
1.50 \\
1.40 \\
1.40 \\
1.50 \\
1.20 \\
1.10 \\
1.10 \\
1.00 \\
.90 \\
.90 \\
.80 \\
.80 \\
.80 \\
.80 \\
.80 \\
.80 \\
.80 \\
.80\end{array}$ \\
\hline
\end{tabular}




\section{MONOCACY RIVER NEAR FREDERICK, MARYLAND.}

This station was established August 4, 1896, by E. G. Paul, at the county bridge on the turnpike 4 miles northeast of Frederick, on the road leading from Frederick to Mount Pleasant, Maryland, about 2,000 feet above the mouth of Israel Creek and 3,000 feet below the mouth of Tuscarora Creek. It is described in Water-Supply Paper No. 35, page 93 . Records of discharge measurements for 1899 will be found in the Twenty-first Annual Report, Part IV, page 98. During 1900 the following measurements were made by Mr. Paul:

June 29: Gage height, 4.10 feet; discharge, 191 second-feet.

September 20: Gage height, 3.80 feet; discharge, 88 second-feet.

Daily gage height, in feet, of Monocacy River near Frederick, Maryland, for 1900.

\begin{tabular}{c|r|r|r|r|r|r|r|r|r|r|r|r}
\hline Day. & Jan. & Feb. & Mar. & Apr. & May. & June. & July. & Aug. & Sept. & Oct. & Nov. & Dec. \\
\hline & & & & & & & & & & & & \\
\hline
\end{tabular}

ROCK CREEK AT ZOOLOGICAL PARK, DISTRICT OF COLUMBIA.

The first station on Rock Creek was established in 1892, at the request of the Commissioners of the District of Columbia. On January 18,1897 , a new station was established on the bridge of the Zoological Park. This bridge was rebuilt in November, 1900, and the gage was destroyed. A new station will be established in 1901 . During 1900 one measurement was made by E. G. Paul, as follows:

April 24: Gage height, 2.75 feet; discharge, 77 second-feet. 
Daily gage height, in feet, of Rock Creek at Zoological Park, District of Columbia, for 1900 .

\begin{tabular}{|c|c|c|c|c|c|c|c|c|c|c|c|}
\hline Day. & Jan. & Feb. & Mar. & Apr. & May. & June. & July. & Aug. & Sept. & Oct. & Nov. \\
\hline 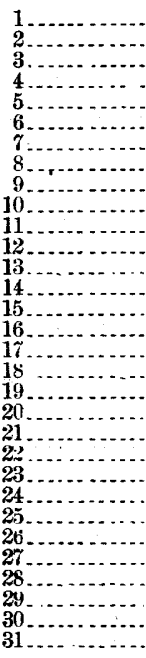 & $\begin{array}{l}2.45 \\
2.43 \\
2.43 \\
2.40 \\
2.38 \\
2.40 \\
2.40 \\
2.40 \\
2.40 \\
2.40 \\
2.43 \\
3.60 \\
3.03 \\
2.88 \\
2.58 \\
2.53 \\
2.80 \\
2.80 \\
2.83 \\
3.08 \\
3.13 \\
2.88 \\
2.80 \\
2.75 \\
2.68 \\
2.60 \\
2.58 \\
2.68 \\
2.48 \\
2.48 \\
2.55\end{array}$ & $\begin{array}{l}2.43 \\
2.43 \\
2.38 \\
2.40 \\
3.03 \\
2.60 \\
2.53 \\
2.83 \\
2.95 \\
2.68 \\
2.60 \\
2.68 \\
3.88 \\
3.00 \\
2.80 \\
2.75 \\
2.70 \\
2.70 \\
2.70 \\
2.78 \\
2.73 \\
5.20 \\
3.35 \\
2.90 \\
2.90 \\
3.08 \\
3.05 \\
2.78\end{array}$ & $\begin{array}{l}3.30 \\
.25 \\
2.88 \\
2.78 \\
2.75 \\
2.80 \\
2.85 \\
2.73 \\
2.70 \\
2.68 \\
2.65 \\
2.70 \\
2.70 \\
2.70 \\
2.68 \\
2.70 \\
2.78 \\
2.80 \\
.87 \\
3.18 \\
2.85 \\
2.80 \\
2.78 \\
2.73 \\
2.75 \\
2.80 \\
2.80 \\
2.80 \\
2.80 \\
2.80\end{array}$ & $\begin{array}{l}2.75 \\
2.70 \\
2.70 \\
2.70 \\
2.68 \\
2.65 \\
2.65 \\
2.65 \\
2.63 \\
2.60 \\
2.60 \\
2.80 \\
2.75 \\
2.68 \\
2.65 \\
2.65 \\
2.70 \\
2.70 \\
. .10 \\
2.80 \\
2.73 \\
2.80 \\
2.80 \\
2.75 \\
2.70 \\
2.70 \\
2.70 \\
2.65 \\
2.60 \\
2.60\end{array}$ & $\begin{array}{l}2.60 \\
2.60 \\
2.60 \\
2.60 \\
2.60 \\
2.55 \\
2.55 \\
2.55 \\
2.60 \\
2.63 \\
2.58 \\
2.55 \\
2.53 \\
2.50 \\
2.50 \\
2.50 \\
2.50 \\
2.50 \\
2.90 \\
2.73 \\
2.50 \\
2.50 \\
2.45 \\
2.50 \\
2.50 \\
2.45 \\
2.45 \\
2.45 \\
2.45 \\
2.40\end{array}$ & $\begin{array}{l}2.45 \\
2.73 \\
2.60 \\
2.55 \\
2.50 \\
2.45 \\
2.45 \\
2.58 \\
2.45 \\
2.45 \\
.40 \\
2.45 \\
2.45 \\
2.48 \\
2.68 \\
2.65 \\
4.30 \\
3.45 \\
2.78 \\
2.70 \\
2.58 \\
2.55 \\
2.50 \\
2.50 \\
2.50 \\
2.48 \\
2.48 \\
2.43 \\
2.35 \\
2.35\end{array}$ & $\begin{array}{l}2.35 \\
2.35 \\
2.35 \\
2.40 \\
2.38 \\
2.38 \\
2.38 \\
2.35 \\
2.33 \\
2.30 \\
2.30 \\
2.30 \\
2.30 \\
2.30 \\
2.30 \\
2.30 \\
2.30 \\
2.30 \\
2.30 \\
2.40 \\
2.40 \\
2.48 \\
2.40 \\
2.73 \\
2.48 \\
2.35 \\
2.38 \\
2.30 \\
2.30 \\
2.30 \\
2.50\end{array}$ & $\begin{array}{l}2.35 \\
2.28 \\
2.30 \\
2.28 \\
2.25 \\
2.25 \\
2.23 \\
2.20 \\
2.20 \\
2.20 \\
2.20 \\
2.15 \\
2.18 \\
2.15 \\
2.15 \\
2.15 \\
2.15 \\
2.15 \\
2.10 \\
2.10 \\
2.18 \\
2.28 \\
2.23 \\
2.25 \\
2.48 \\
2.28 \\
2.20 \\
2.20 \\
2.20 \\
2.20 \\
2.15\end{array}$ & $\begin{array}{l}2.15 \\
2.13 \\
2.10 \\
2.10 \\
2.10 \\
2.10 \\
2.10 \\
2.10 \\
2.10 \\
2.10 \\
2.10 \\
2.10 \\
2.10 \\
2.10 \\
2.13 \\
2.65 \\
2.40 \\
2.20 \\
2.17 \\
2.15 \\
2.15 \\
2.15 \\
2.15 \\
2.15 \\
2.15 \\
2.15 \\
2.15 \\
2.45 \\
2.40 \\
2.60\end{array}$ & $\begin{array}{l}2.40 \\
2.30 \\
2.20 \\
2.20 \\
2.20 \\
2.20 \\
2.15 \\
2.25 \\
2.25 \\
2.20 \\
2.20 \\
2.20 \\
2.23 \\
2.35 \\
2.35 \\
2.30 \\
2.25 \\
2.20 \\
2.20 \\
2.20 \\
2.20 \\
2.20 \\
2.20 \\
2.25 \\
2.23 \\
2.18 \\
2.15 \\
.2 .15 \\
2.10 \\
2.10 \\
2.10\end{array}$ & \begin{tabular}{l}
2.10 \\
2.15 \\
2.15 \\
2.28 \\
2.35 \\
2.28 \\
2.25 \\
2.40 \\
2.48 \\
2.43 \\
\hdashline \\
\hdashline.. \\
\end{tabular} \\
\hline
\end{tabular}

APPOMATTOX RIVER AT MATTOAX, VIRGINIA.

This station was established in August, 1900, at the crossing of the Southern Railway, 27 miles southwest of Richmond. The gage rod, which is on the guard rail of the bridge, is laid off to feet and tenths, graduations being indicated by brass nails. . The zero of the rod is 58.1 feet from the west end of the bridge, on the upstream side. The outer rim of the pulley is 0.9 foot from the zero of the rod; the distance from the end of the weight to the pointer on the wire rope is 48.75 feet. When the gage reading is 1 foot the water level is 45.6 feet below the top surface of the upper chord of the bridge, upstream side, and at the zero of the gage.

The river here is straight for a considerable distance above the station, but there is an abrupt bend about 100 feet below the bridge. The river is very narrow, and at the low stage at which the gage was placed the current velocity is not very well distributed, there being practically no current for several feet next to the west bank. It was possible, however, to secure a good gaging, and old residents stated that the river was at the lowest stage it had reached in fourteen years. The Mattoax railroad station is located on the west bank of the river, and J. C. Carter, the station agent, is the observer. During 1900 the following measurements were made by $\mathrm{E}$. W. Myers:

August 25: Gage height, 1 foot; discharge, 196 second-feet.

November 1: Gage height, 0.85 foot; discharge, 177 second-feet. 
JAMES RIVER AT BUCHANAN, VIRGINIA.

This station, which was established August 18, 1895, by C. C. Babb and D. C. Humphreys, is located about 20 miles above the mouth of North River and a half mile above the mouth of Purgatory Creek. It is described in Water-Supply Paper No. 35, page 97. Records of measurements for 1899 will be found in the Twenty-first Annual Report, Part IV, page 108. During 1900 the following measurements were made by D. C. Humphreys:

March 30: Gage height, 4.62 feet; discharge, 4,453 second-feet. June 28: Gage height, 2.80 feet; discharge, 1,043 second-feet.

Angust 4: Gage height, 2.25 feet; discharge, 523 second-feet.

August 21: Gage height, 1.85 feet; discharge, 374 second-feet.

December 20: Gage height, 2.93 feet; discharge, 1,197 second-feet.

Daily gage height, in feet, of James River at Buchanan, Virginia, for 1900.

\begin{tabular}{|c|c|c|c|c|c|c|c|c|c|c|c|c|}
\hline Day. & Jan. & Feb. & Mar. & Apr. & May. & June. & July. & Aug. & Sept. & Oct. & Nov. & Dec. \\
\hline 310 & $\begin{array}{l}2.20 \\
2.20 \\
2.20 \\
2.10 \\
2.10 \\
2.10 \\
2.00 \\
2.00 \\
2.00 \\
2.10 \\
2.40 \\
3.10 \\
4.20 \\
3.55 \\
3.15 \\
2.95 \\
2.80 \\
2.80 \\
3.75 \\
9.30 \\
8.15 \\
5.60 \\
4.55 \\
3.95 \\
3.50 \\
3.30 \\
3.20 \\
2.75 \\
2.55 \\
2.40 \\
2.40\end{array}$ & $\begin{array}{l}2.40 \\
2.40 \\
2.30 \\
2.35 \\
2.55 \\
2.50 \\
2.50 \\
2.95 \\
3.65 \\
3.80 \\
3.50 \\
3.35 \\
6.85 \\
9.20 \\
6.10 \\
5.50 \\
4.55 \\
4.30 \\
3.60 \\
3.35 \\
3.30 \\
7.00 \\
7.45 \\
5.40 \\
4.60 \\
4.80 \\
4.15\end{array}$ & $\begin{array}{r}6.80 \\
9.25 \\
6.80 \\
5.50 \\
4.90 \\
4.55 \\
4.40 \\
4.40 \\
4.60 \\
4.35 \\
4.20 \\
4.05 \\
3.90 \\
3.75 \\
3.60 \\
3.60 \\
3.50 \\
3.40 \\
3.50 \\
9.50 \\
10.30 \\
7.40 \\
5.95 \\
5.20 \\
4.95 \\
4.85 \\
4.80 \\
4.90 \\
4.75 \\
4.60 \\
4.60\end{array}$ & $\begin{array}{l}4.40 \\
4.15 \\
4.00 \\
3.90 \\
3.80 \\
3.70 \\
3.60 \\
3.50 \\
3.35 \\
3.20 \\
3.10 \\
3.00 \\
3.00 \\
3.00 \\
2.90 \\
2.80 \\
2.80 \\
2.95 \\
4.15 \\
4.90 \\
4.65 \\
4.70 \\
5.45 \\
4.85 \\
4.40 \\
4.25 \\
3.85 \\
3.70 \\
3.25 \\
3.15\end{array}$ & $\begin{array}{l}3.10 \\
3.00 \\
2.90 \\
2.85 \\
2.80 \\
2.80 \\
2.70 \\
2.65 \\
2.50 \\
2.55 \\
2.50 \\
2.50 \\
2.50 \\
2.40 \\
2.40 \\
2.40 \\
2.30 \\
2.30 \\
2.25 \\
2.90 \\
2.85 \\
2.65 \\
2.50 \\
2.65 \\
4.50 \\
4.00 \\
3.45 \\
3.20 \\
3.10 \\
3.00 \\
3.00\end{array}$ & $\begin{array}{l}2.85 \\
2.75 \\
3.30 \\
3.05 \\
2.90 \\
2.80 \\
2.70 \\
2.70 \\
2.60 \\
2.50 \\
2.50 \\
2.50 \\
3.10 \\
2.80 \\
2.80 \\
4.60 \\
6.30 \\
6.90 \\
6.00 \\
4.65 \\
4.15 \\
3.90 \\
3.25 \\
3.05 \\
3.00 \\
2.90 \\
2.80 \\
2.70 \\
2.70 \\
2.70\end{array}$ & $\begin{array}{l}2.70 \\
2.60 \\
2.60 \\
2.60 \\
2.50 \\
2.50 \\
2.40 \\
2.40 \\
2.30 \\
2.20 \\
2.20 \\
2.30 \\
2.30 \\
2.20 \\
2.20 \\
2.10 \\
2.00 \\
2.00 \\
2.00 \\
2.00 \\
2.00 \\
2.00 \\
2.00 \\
2.00 \\
2.10 \\
3.10 \\
3.20 \\
3.15 \\
3.30 \\
2.75 \\
2.55\end{array}$ & $\begin{array}{l}2.40 \\
2.30 \\
2.30 \\
2.25 \\
2.10 \\
2.10 \\
2.00 \\
2.00 \\
2.00 \\
1.90 \\
1.90 \\
1.90 \\
1.90 \\
1.90 \\
1.90 \\
1.80 \\
1.80 \\
1.80 \\
1.70 \\
1.70 \\
1.80 \\
1.80 \\
1.80 \\
1.90 \\
1.90 \\
1.90 \\
1.90 \\
1.90\end{array}$ & $\begin{array}{l}1.90 \\
1.90 \\
1.90 \\
2.15 \\
2.90 \\
2.80 \\
2.20 \\
1.95 \\
1.80 \\
1.80 \\
1.80 \\
1.70 \\
1.70 \\
1.70 \\
2.10 \\
3.15 \\
3.35 \\
2.60 \\
2.35 \\
2.20 \\
2.10 \\
2.10 \\
2.10 \\
2.20 \\
2.10 \\
2.10 \\
2.10 \\
2.20 \\
2.20 \\
2.20\end{array}$ & $\begin{array}{r}2.20 \\
2.20 \\
2.20 \\
2.20 \\
2.10 \\
2.10 \\
2.10 \\
2.10 \\
2.10 \\
2.10 \\
2.10 \\
2.10 \\
2.10 \\
2.10 \\
2.35 \\
2.70 \\
2.60 \\
2.45 \\
2.30 \\
2.20 \\
2.20 \\
2.30 \\
10.45 \\
5.65 \\
4.10 \\
2.90 \\
2.70 \\
2.60 \\
2.60 \\
2.60\end{array}$ & $\begin{array}{r}2.50 \\
2.50 \\
2.80 \\
3.45 \\
3.55 \\
3.25 \\
2.95 \\
2.80 \\
2.70 \\
2.60 \\
2.60 \\
2.50 \\
2.50 \\
2.50 \\
2.50 \\
2.40 \\
2.40 \\
2.40 \\
2.40 \\
2.30 \\
2.30 \\
2.30 \\
2.30 \\
4.65 \\
1.25 \\
12.60 \\
6.20 \\
5.85 \\
4.85\end{array}$ & $\begin{array}{l}4.20 \\
3.80 \\
3.70 \\
6.05 \\
9.30 \\
6.25 \\
5.35 \\
4.95 \\
4.75 \\
4.40 \\
3.95 \\
3.80 \\
3.65 \\
3.50 \\
3.35 \\
3.20 \\
3.10 \\
3.10 \\
3.00 \\
2.90 \\
2.90 \\
2.90 \\
2.80 \\
3.05 \\
3.10 \\
3.00 \\
3.00 \\
2.90 \\
2.90 \\
2.80 \\
2.80\end{array}$ \\
\hline
\end{tabular}

JAMES RIVER AT CARTERSVILLE, VIRGINIA.

This station, which was established January 1, 1899, by D. C. Humphreys, is located at the highway bridge crossing the James at Cartersville, a half mile from the railroad station and 50 miles above Richmond, Virginia. It is described in Water-Supply Paper No. 35, page 98, together with a number of other gages that have been installed on this river. Records of measurements for the year 1899 
will be found in Paper No. 35, page 99. During 1900 the following measurements were made by D. C. Humphreys:

April 2: Gage height, 4.74 feet; discharge, 9,469 second-feet.

June 30: Gage height, 2.34 feet; discharge, 4,049 second-feet.

August 8: Gage height, 0.97 foot; discharge, 1,515 second-feet.

August 24: Gage height, 1.00 foot; discharge, 1,405 second-feet.

December 22: Gage height, 2.08 feet; discharge, 3,360 second-feet.

Daily gage height, in feet, of James River at Cartersville, Virginia, for 1900.

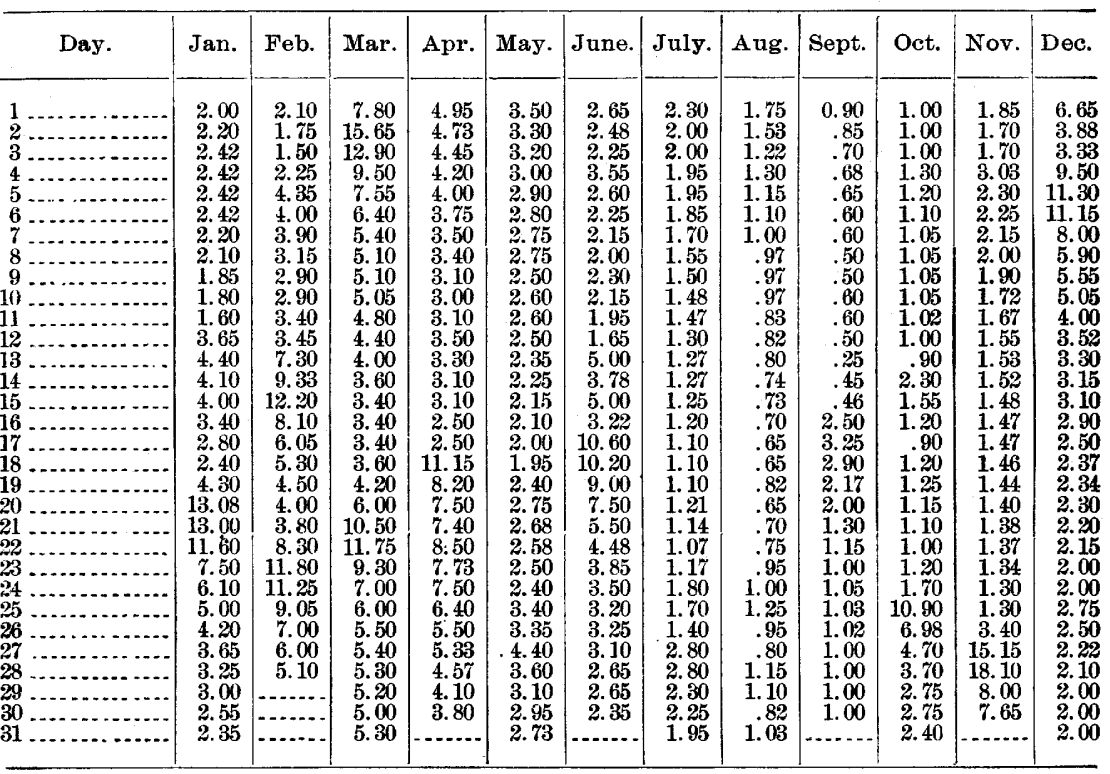

JAMES RIVER AT HOLCOMB ROCK, VIRGINIA.

This station was established by the Willson Aluminum Company, of Holcomb Rock, Virginia, in 1899, in connection with measurements to determine the horsepower available at that point. During 1899 the records were fragmentary, but at the commencement of 1900 daily records were taken, which have been furnished to the Geological Survey through the courtesy of T. R. Ragland, general manager of the company. The gage consists of a copper float 8 by 8 by 8 inches, with a vertical rod $1 \frac{1}{2}$ inches square attached to it, the rod, which extends up through the power-house floor, being scaled to tenths of a foot. The copper float is inclosed in a 12-inch by 12-inch by 12 -foot box, which rests solidly on the bottom of the river. The box is perforated, so that the water in it will always stand at the same level as the water in the river, while the float, being inclosed, is not in danger of being broken by floating timber. The fluctuations of the river are read directly from the rod, which moves up or down with the float as it responds to the variations in the height of the river. Measurements of discharge are not made at this point. 
Daily gage height, in feet, of James River at Holcomb Rock, Virginia, for 1900.

\begin{tabular}{r|r|r|r|r|r|r|r|r|r|r|r|r}
\hline Day. & Jan. & Feb. & Mar. & Apr. & May. & June. & July. & Aug. & Sept. & Oct. & Nov. & Dec. \\
\hline & & & & & & & & & & \\
\hline
\end{tabular}

ROANOKE RIVER AT ROANOKE, VIRGINIA.

This station, which was established by D. C. Humphreys, July 11, 1896, is located at the edge of the city of Roanoke, on the Walnut street car line. It is described in Water-Supply Paper No. 36, page 107 , and record of discharge measurements for 1899 will be found in the Twenty-first Annual Report, Part IV, page 110. During 1900 the following measurements were made by D. C. Humphreys:

March 29: Gage height, 2.07 feet; discharge, 879 second-feet.

May 5: Gage height, 1.30 feet; discharge, 298 second-feet.

June 26: Gage height, 2.16 feet; discharge, 639 second-feet.

July 30: Gage height, 0.91 foot; discharge, 149 second-feet.

August 21: Gage height, 0.65 foot; discharge, 92 second-feet.

December 19: Gage height, 1.2૪ feet; discharge, 307 second-feet. 
Daily gage height, in feet, of Roanoke River at Roanoke, Virginia, for 1900.

\begin{tabular}{r|r|r|r|r|r|r|r|r|r|r|r|r}
\hline Day. & Jan. & Feb. & Mar. & Apr. & May. & June. & July. & Aug. & Sept. & Oct. & Nov. & Dec. \\
\hline & & & & & & & & \\
\hline
\end{tabular}

$a$ Interpolated.

$b$ Estimated; repairing bridge.

ROANOKE RIVER AT NEAL, NORTH CAROLINA.

This station is described in Water-Supply Paper No. 36, page 109. The river bed is muddy and is likely to cut out in seasons of high water, and both banks are subject to overflow, sometimes covering the flood plain of the river to a depth of 10 or more feet and reaching at times a width of nearly 2 miles. The highest recorded water at this station occurred on March 23, 1899, when the gage reached a height of 30 feet and the discharge was probably 83,000 second-feet; the lowest recorded water was from September 19 to 22,1897 , when the gage read 0.00 and the discharge was probably 2,000 second-feet, making the maximum flow $41 \frac{1}{2}$ times the minimum flow. The drainage area above the station is 8,817 square miles, largely forest covered and including a variety of. topographic forms, from the mountains of the upper part of Dan and Staunton rivers to the extensive swamps to be found along the lower part of the basin. The stream is subject to sudden rises and falls, but the period of high water lasts several days. The observer is the bridge watchman, W. M. Adams, of Kelford, North Carolina. Records of measurements will be found as follows: For 1896, Eighteenth Annual Report, Part IV, page 48; for 1897, Nineteenth Annual Report, Part IV, page 181; for 1898, Twentieth Annual Report, Part IV, page 142; for 1899, Twenty-first Annual Report, Part IV, page 
111. During 1900 the following measurements were made by $\mathbf{E}$. W. Myers:

February 10: Gage height, 9.70 feet; discharge, 9,361 second-feet.

April 10: Gage height, 7.10 feet; discharge 6,266 second-feet.

April 11: Gage height, 6.90 feet; discharge, 6,002 second-feet.

April 24: Gage height, 25.60 feet: discharge, 49,896 second-feet.

May 11: Gage height, 4.69 feet; discharge, 5,503 second-feet.

June 30: Gage height, 10.12 feet; discharge, 9,530 second-feet.

August 10: Gage height, 1.40 feet; discharge, 2,342 second-feet.

November 2: Gage height, 3.18 feet; discharge 3,734 second-feet.

Daily gage height, in feet, of Roanoke River at Neal, North Carolina, for 1900.

\begin{tabular}{r|r|r|r|r|r|r|r|r|r|r|r|r}
\hline Day. & Jan. & Feb. & Mar. & Apr. & May. & June. & July. & Aug. & Sept. & Oct. & Nov. & Dec. \\
\hline & & & & & & & \\
\hline & & & & & & & \\
\hline
\end{tabular}

\section{DAN RIVER AT SOUTH BOSTON, VIRGINIA.}

This station, which was established August 27, 1900, by E. W. Myers, is located in the town of South Boston, Virginia, on the railroad bridge of the Norfolk and Western Railroad which crosses the river at that place. The gage rod is laid off on the dewnstream guard rail of the bridge, the graduations being indicated by brass nails driven into the rail. The zero of the rod is exactly over the center of the first span from the north end of the bridge. The distance between the zero of the rod and the outer rim of the pulley is 2.39 feet, and the distance between the end of the weight and the pointer on the wire rope is 36.44 feet. When the gage reading is 1 foot the water surface is 31.06 feet below the top of the head of the nut on the pin connecting the two tension rods with the lower chord of the bridge, this pin being on the lower side of the bridge and exactly opposite the zero of the gage. This is a very good station for 
the gaging of all except the very highest stages of flow. At extreme heights the river spreads out over a flood plain of considerable width. The trestle connecting the bridge with the embankment on the south side of the river is a curve of rather high degree. The bed of the stream is of coarse sand and probably shifts only slightly. R. M. Taliaferro, South Boston, Virginia, is the observer. During 1900 the following measurements were made by $\mathrm{E}$. W. Myers:

August 27: Gage height, 1.00 foot; discharge, 1,046 second-feet.

October 31: Gage height, 2.20 feet; discharge, 1,576 second-feet.

Daily gage height, in feet, of Dan River at South Boston, Virginia, for 1900.

\begin{tabular}{|c|c|c|c|c|c|c|c|c|c|}
\hline Day. & Sept. & Oct. & Nov. & Dec. & Day. & Sept. & Oct. & Nov. & Dec. \\
\hline $\begin{array}{r}1 \\
2 \\
3 \\
4 \\
56 \\
6 \\
8 \\
90 \\
10 \\
112 \\
13\end{array}$ & $\begin{array}{l}0.62 \\
.55 \\
.95 \\
.95 \\
.60 \\
.95 \\
.77 \\
.90 \\
.87 \\
.40 \\
.50 \\
.30 \\
.40 \\
.45 \\
.40 \\
4.90\end{array}$ & $\begin{array}{l}1.50 \\
1.50 \\
1.50 \\
1.50 \\
1.40 \\
1.30 \\
1.90 \\
1.90 \\
2.40 \\
2.40 \\
2.40 \\
2.20 \\
2.20 \\
2.30 \\
2.00 \\
2.00\end{array}$ & $\begin{array}{l}2.00 \\
2.20 \\
2.00 \\
2.40 \\
2.10 \\
2.50 \\
2.70 \\
2.50 \\
2.50 \\
2.40 \\
2.00 \\
2.00 \\
2.00 \\
1.90 \\
1.90 \\
1.80\end{array}$ & $\begin{array}{r}3.00 \\
3.00 \\
3.00 \\
4.00 \\
14.10 \\
8.00 \\
4.80 \\
3.80 \\
3.50 \\
3.20 \\
3.20 \\
3.20 \\
3.20 \\
3.10 \\
2.90 \\
2.90\end{array}$ & $\begin{array}{l}17 \\
18 \\
19 \\
20 \\
20 \\
22 \\
23 \\
24 \\
24 \\
26 \\
26 \\
27 \\
28 \\
29 \\
20 \\
30 \\
31\end{array}$ & $\begin{array}{l}8.55 \\
3.60 \\
2.00 \\
1.65 \\
1.25 \\
1.55 \\
1.30 \\
1.70 \\
1.70 \\
1.50 \\
1.60 \\
1.40 \\
1.30 \\
1.30\end{array}$ & $\begin{array}{l}2.40 \\
2.40 \\
2.00 \\
2.00 \\
1.90 \\
2.00 \\
2.00 \\
2.30 \\
7.50 \\
3.50 \\
3.50 \\
2.50 \\
2.50 \\
.50 \\
2.00\end{array}$ & $\begin{array}{l}1.70 \\
1.70 \\
1.70 \\
1.70 \\
1.70 \\
1.70 \\
1.60 \\
1.60 \\
1.60 \\
2.20 \\
5.60 \\
3.80 \\
3.20 \\
3.00\end{array}$ & $\begin{array}{l}3.00 \\
3.00 \\
2.00 \\
2.90 \\
3.00 \\
3.10 \\
3.10 \\
3.10 \\
3.00 \\
3.00 \\
3.00 \\
3.20 \\
3.00 \\
2.70 \\
2.80\end{array}$ \\
\hline
\end{tabular}

STAUNTON RIVER AT RANDOLPH, VIRGINIA.

This station, which was established August 27, 1900, by E. W. Myers, is about five-eighths of a mile southwest of Randolph station, on the line of the Southern Railway from Richmond to Danville, on the railroad bridge which crosses the river at that place. The rod is laid off on the guard rail of the bridge on the downstream side, the graduations to feet and tenths being indicated by brass tacks. The zero of the gage rod is over the center of the fifth floor beam of the second span from the north end of the bridge. The distance between the zero of the rod and the outer rim of the pulley is 3.66 feet; the distance between the end of the weight and the pointer on the wire rope is 41.13 feet. When the gage reading is 1 foot the water surface is 34.85 feet below the top surface of the fifth floor beam, directly under the zero of the gage. The river is straight for a long distance above and below the bridge, and the velocity of the current is very well distributed. It is said that the rise at this point is about 25 feet. It is not probable that the channel changes to any degree during high water. The observer at this station is Justin Field, station agent at Randolph. During 1900 the following measurements were made by E. W. Myers:

August 27: Gage height, 1.00 foot; discharge, 1,349 second-feet. October 31: Gage height, 2.75 feet; discharge, 2,304 second-feet.

IRR 48-01-3 
Daily gage height, in feet, of Staunton River at Randolph, Virginia, for 1900.

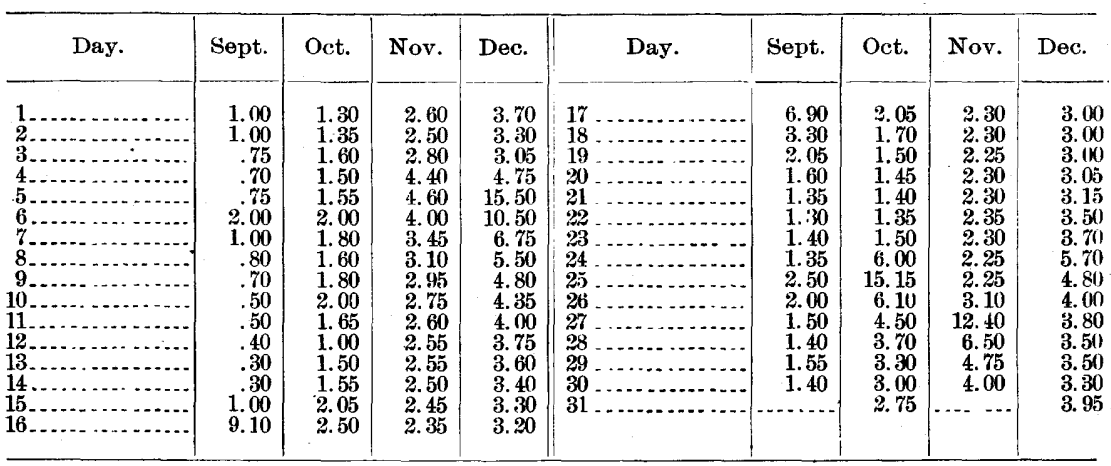

TAR RIVER AT TARBORO, NORTH CAROLINA.

This station is described in Water-Supply Paper No. 36, page 110. Extensive sand bars have formed in the channel during periods of extreme low water, and they modify very materially the relation between the gage height and the discharge at low stages of the river. The highest recorded flood was on February 11, 1899, when the gage height was 25 feet and the discharge was probably 19,850 second-feet. The lowest recorded flow was on November 2, 1900, the discharge being 87 second-feet, the maximum flow thus being about 218 times the minimum flow. The observer is $R$. H. Williams, who reads the gage once a day during ordinary stages of the river, but oftener during floods. Measurements of discharge are made at the station and occasionally at the highway bridge crossing the stream about 200 yards above, as the lower section is sometimes obstructed by rafts of logs. Records of flow during 1899 will be found in the Twentyfirst Annual Report, Part IV, page 112. During 1900 the following measurements were made by E. W. Myers:

April 11: Gage height, 4.48 feet; discharge, 1,915 second-feet. April 23: Gage height, 14.90 feet; discharge, 10,237 second-feet. May 18: Gage height, 2.18 feet; discharge, 1,003 second-feet. June 30: Gage height, 2.30 feet, discharge, 1,030 second-feet. August 9: Gage height, 0.40 foot, discharge, 371 second-feet. November 2: Gage height, -0.30 foot; discharge, 87 second-feet. November 21: Gage height, 0.50 foot; discharge, 412 second-feet. 
Daily gage height, in feet, of Tar River at Tarboro, North Carolina, for 1900.

\begin{tabular}{|c|c|c|c|c|c|c|c|c|c|c|c|c|}
\hline Day. & Jan. & Feb. & Mar. & Apr. & May. & June. & July. & Aug. & Sept. & Oct. & Nov. & Dec. \\
\hline & & 4.0 & & & & 2.6 & 2.0 & & & -0.2 & -0.3 & \\
\hline${ }_{3}^{2}-$ & $\begin{array}{l}3.0 \\
20\end{array}$ & $\begin{array}{l}3.8 \\
3.7\end{array}$ & 10.5 & $\begin{array}{l}9.0 \\
9.1\end{array}$ & 4.5 & 2.1 & 1.3 & 1.3 & .4 & -.2 & -.2 & .7 \\
\hline & 2.6 & $\begin{array}{l}0.6 \\
3.6\end{array}$ & $\begin{array}{l}12.3 \\
13.5\end{array}$ & $\begin{array}{l}9.1 \\
8.0\end{array}$ & $\begin{array}{l}4.6 \\
4.3\end{array}$ & $\begin{array}{l}2.0 \\
1.9\end{array}$ & $\begin{array}{l}1.5 \\
1.6\end{array}$ & $\begin{array}{l}1.6 \\
1.8\end{array}$ & .2 & $=.2$ & 1.8 & .6 \\
\hline & 5 & 3.5 & $\begin{array}{l}14.3 \\
14.5\end{array}$ & 7.5 & $\begin{array}{l}\text { 4. } 0 \\
\text { 4. } 0\end{array}$ & $\begin{array}{l}1.8 \\
1.8\end{array}$ & $\begin{array}{l}1.0 \\
1.0\end{array}$ & $\begin{array}{r}1.0 \\
.7\end{array}$ & .0 & & 3.4 & 1.0 \\
\hline & 6 & 4.8 & 13.0 & 7.6 & $\overline{3} .7$ & 1.5 & 1.1 & .6 & .0 & -.1 & $4 . \overline{\mathbf{5}}$ & 1.6 \\
\hline & 3.4 & 6.0 & 10.5 & 7.3 & 3.4 & 1.3 & .7 & 5 & 0 & -.2 & 5.1 & 37 \\
\hline & 3.5 & 5.9 & 3 & 6.0 & 3.2 & 1.2 & 6 & 2 & - & -.2 & 3.8 & 3.0 \\
\hline & 3.4 & 5.4 & 7.8 & 5.3 & 3. 0 & 1.3 & .7 & 1 & & 1.2 & 3.4 & 2.1 \\
\hline & 4.3 & 5.0 & 9.0 & 5.0 & 3.3 & 1.5 & .6 & .0 & & .5 & 2.0 & 1.6 \\
\hline & 3.4 & 6.1 & 11.2 & 4.7 & 3.6 & 2.0 & .4 & .0 & -.1 & 4 & 1.6 & 1.7 \\
\hline 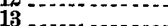 & $\begin{array}{l}0.0 \\
3.7\end{array}$ & 1.8 & 12. 2 & 4.5 & 4.0 & 1.8 & 3 & .0 & & 3 & 1.4 & 1.5 \\
\hline 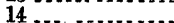 & 9.4 & 10.6 & $\begin{array}{ll}11.4 \\
.8\end{array}$ & $\begin{array}{l}5.6 \\
8.6\end{array}$ & 3.1 & 1.3 & $\begin{array}{l}4 \\
{ }_{2}^{2}\end{array}$ & 0 & & 4 & 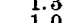 & 1.2 \\
\hline & $\begin{array}{c}0.4 \\
10.5\end{array}$ & 14.8 & $\begin{array}{l}9.8 \\
8.0\end{array}$ & 8.1 & .85 & 1.4 & .3 & .0 & & 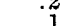 & 1.0 & .9 \\
\hline & 9.5 & 15.8 & 73 & 93 & 24 & 1.0 & 1.6 & 3 & & 0 & 0 & 8 \\
\hline & 7.3 & 17.0 & 8.3 & 8.3 & 2.2 & 2.5 & 1.4 & 1.3 & -.2 & 0 & .6 & 6 \\
\hline & & 18.0 & 9.1 & 7.2 & 2.0 & 3.5 & .7 & .5 & .5 & 0 & .4 & 1.1 \\
\hline & 5.9 & 16.5 & 9.5 & 6.0 & 4.0 & 6.0 & .3 & 1.0 & $t .0$ & 0 & .2 & .7 \\
\hline & & 15.7 & $\begin{array}{l}8.0 \\
7.9\end{array}$ & 9.4 & 5.0 & 7.3 & .2 & .7 & 4 & .0 & .7 & .6 \\
\hline & 8.9 & & 4.8 & $\begin{array}{l}10.8 \\
10.8\end{array}$ & 4.8 & $\begin{array}{l}0.0 \\
1.2\end{array}$ & .1 & ${ }^{0}$ & $0_{0}^{2}$ & -.1 & .4 & 1.2 \\
\hline & 10.8 & 100 & 6.1 & 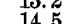 & 4 & 年. & $0_{0}^{\circ}$ &.$\frac{4}{2}$ & 0 & - & 1 & $2 . \frac{1}{78}$ \\
\hline & & 115 & 60 & 153 & 30 & . & 0 & .1 & 0 & & $\cdot \frac{1}{3}$ & 5.7 \\
\hline$\ldots$ & 7.3 & 13.9 & 6.1 & 13 & 5 & 4.3 & .0 & .0 & -.1 & $-\tilde{2}$ & .4 & $\begin{array}{l}4.0 \\
4.0\end{array}$ \\
\hline & 6.4 & 13.7 & 6.3 & 11.0 & 5.9 & 6.5 & .5 & .1 & -.1 & -.1 & .5 & 2.8 \\
\hline & 5.5 & 12.6 & 3 & 8.6 & 5. 6 & 5.0 & 1.0 & .2 & -.1 & -.1 & .4 & 2.6 \\
\hline$\cdots$ & $\begin{array}{l}.0 \\
4.6\end{array}$ & & 100 & 6.0 & 4.5 & 3.4 & $\begin{array}{l}1.2 \\
4.5\end{array}$ & .0 & $=.1$ & 二.12 & $i_{3}^{\circ}$ & 3.2 \\
\hline & 4.5 & & 9.1 & 5.4 & 3.0 & 2.6 & 3. 0 & .4 & -.1 & -.3 & 1.2 & 2.5 \\
\hline & 4.4 & & 7.8 & & 2.8 & & 2.3 & 6 & & & & 3.2 \\
\hline
\end{tabular}

NEUSE RIVER AT SELMA, NORTH CAROLINA.

This station is described in Water-Supply Paper No. 36, page 111. The maximum flood of which there is any record was on February 9, 1899 , when the water reached a height of 21 feet on the gage, with a probable discharge of 12,000 second-feet. The minimum flow occurred during the very severe drought of 1897, the lowest gage height being -0.4 foot, on October 17 and 18, and the discharge 75 second-feet, making the maximum flow about 160 times the minimum flow. The drainage area above the station is 1,175 square miles. Records of flow during 1899 will be found in the Twenty-first Annual Report, Part IV, page 114. During 1900 the following measurements were made by $\mathrm{E}$. W. Myers:

February 8: Gage height, 3.40 feet; discharge, 1,117 second-feet. April 12: Gage height, 3.80 feet; discharge, 1,076 second-feet. April 24: Gage height, 17.05 feet; discharge, 9,027 second-feet. May 17: Gage height, 1.70 feet; discharge, 461 second-feet. June 27: Gage height, 3.00 feet; discharge, 590 second-feet. August 10: Gage height, 0.61 foot; discharge, 139 second-feet. November 6: Gage height, 4.60 feet; discharge, 1,278 second-feet. November 22: Gage height, 0.90 foot; discharge, 243 second-feet. 
Daily gage height, in feet, of Neuse River at Selma, North Carolina, for 1900.

\begin{tabular}{r|r|r|r|r|r|r|r|r|r|r|r|r}
\hline Day. & Jan. & Feb. & Mar. & Apr. & May. & June. & July. & Aug. & Sept. & Oct. & Nov. & Dec. \\
\hline & & & & & & & & & & & \\
\hline
\end{tabular}

DEEP RIVER AT CUMNOCK, NORTH CAROLINA.

This station was established June 29, 1900, by E. W. Myers. It is 300 yards northwest of the railroad station at Cumnock. The wire gage, which is graduated to feet and tenths, is nailed to the guard rail of the bridge. The water surface is 37.41 feet below the top of the lower chord at the side of the tension rod supporting the floor beam opposite the gage. The initial point of sounding is at the northwest end of the bridge. The channel is straight for several hundred feet above and below the bridge, but the current is rather sluggish during low water. The bed of the stream is muddy, with some bowlders. The observer is J. A. Rollins, a watchman at Cumnock. During 1900 the following measurements were made by $\mathrm{E}$. W. Myers:

June 29: Gage height, 3.00 feet; discharge, 540 second-feet.

August 11: Gage height, 1.30 feet; discharge, 112 second-feet.

November 5: Gage height, 4.55 feet; discharge, 1,118 second-feet.

December 19: Gage height, 1.70 feet; discharge, 199 second-feet. 
Daily gage height, in feet, of Deep River at Cumnock, North Carolina, for 1900.

\begin{tabular}{|c|c|c|c|c|c|c|c|c|c|c|c|c|c|}
\hline Day. & July. & Aug. & Sept. & Oct. & Nov. & Dec. & Day. & July. & Aug. & Sept. & Oct. & Nov. & Dec. \\
\hline 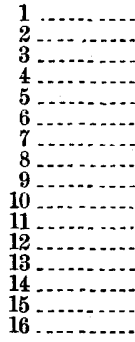 & $\begin{array}{l}2.24 \\
2.04 \\
1.85 \\
2.95 \\
2.14 \\
1.87 \\
(a) \\
(a) \\
(a) \\
(a) \\
(a) \\
(a) \\
(a) \\
(a) \\
(a) \\
(a)\end{array}$ & $\begin{array}{l}1.54 \\
1.54 \\
1.65 \\
1.37 \\
1.35 \\
1.53 \\
1.34 \\
1.13 \\
1.18 \\
1.29 \\
1.30 \\
1.20 \\
1.27 \\
1.30 \\
1.43 \\
1.37\end{array}$ & $\begin{array}{l}2.02 \\
1.79 \\
1.69 \\
1.47 \\
1.34 \\
1.35 \\
1.44 \\
1.36 \\
1.27 \\
1.37 \\
1.37 \\
1.32 \\
1.37 \\
1.45 \\
1.50 \\
8.52\end{array}$ & $\begin{array}{l}1.31 \\
1.35 \\
1.14 \\
1.21 \\
1.10 \\
1.16 \\
1.00 \\
1.28 \\
1.50 \\
1.77 \\
1.82 \\
1.60 \\
1.46 \\
1.32 \\
2.11 \\
2.11\end{array}$ & $\begin{array}{l}1.32 \\
1.24 \\
1.39 \\
9.19 \\
5.43 \\
2.89 \\
2.26 \\
1.88 \\
1.83 \\
1.68 \\
1.60 \\
1.50 \\
1.40 \\
1.34 \\
1.33 \\
1.62\end{array}$ & $\begin{array}{l}1.58 \\
1.70 \\
2.94 \\
6.96 \\
9.99 \\
4.66 \\
3.17 \\
2.26 \\
2.13 \\
1.90 \\
1.72 \\
1.74 \\
1.85 \\
1.70 \\
1.50 \\
1.66\end{array}$ & $\begin{array}{l}17 .- \\
18 . \\
19 .- \\
20 . \\
21 . \\
22 . \\
23 . \\
24 . \\
25 .- \\
26 .- \\
27 . \\
28 . \\
29 .- \\
31 .\end{array}$ & $\begin{array}{c}(a) \\
(a) \\
(a) \\
1.24 \\
.72 \\
.96 \\
1.25 \\
1.88 \\
1.54 \\
1.50 \\
4.27 \\
3.39 \\
2.35 \\
1.90 \\
1.54\end{array}$ & $\begin{array}{l}1.75 \\
1.20 \\
.85 \\
1.14 \\
1.10 \\
1.12 \\
1.45 \\
2.34 \\
1.76 \\
1.46 \\
1.41 \\
1.34 \\
1.25 \\
2.35 \\
2.59\end{array}$ & $\begin{array}{l}4.40 \\
2.04 \\
1.92 \\
1.78 \\
1.67 \\
1.45 \\
1.43 \\
1.53 \\
1.55 \\
1.56 \\
1.51 \\
1.55 \\
1.50 \\
1.21\end{array}$ & $\begin{array}{l}1.95 \\
1.66 \\
1.57 \\
1.39 \\
1.34 \\
1.38 \\
1.43 \\
1.50 \\
1.36 \\
1.28 \\
1.34 \\
1.14 \\
1.30 \\
1.33 \\
1.40\end{array}$ & $\begin{array}{l}1.69 \\
1.39 \\
1.80 \\
1.72 \\
1.71 \\
1.80 \\
1.39 \\
1.44 \\
1.28 \\
1.82 \\
1.86 \\
1.55 \\
1.45 \\
1.80 \\
\cdots\end{array}$ & $\begin{array}{l}1.58 \\
1.38 \\
1.75 \\
1.70 \\
5.77 \\
8.23 \\
4.63 \\
3.31 \\
3.10 \\
2.95 \\
2.88 \\
2.24 \\
2.23 \\
2.35 \\
4.22\end{array}$ \\
\hline
\end{tabular}

a. No record.

CAPE FEAR RIVER AT FAYETTEVILLE, NORTH CAROLINA.

This station is described in Water-Supply Paper No. 36, page 115. The maximum flood of which there is any record occurred on January 12,1895 , when the river reached a height of 58 feet on the gage, and the discharge was at the rate of about 91,000 cubic feet per second. The lowest stage of flow was on October 8 and 9,1897 , when the gage height was 0.2 foot and the discharge 340 second-feet. The maximum discharge is therefore about 270 times the minimum flow. The drainage area above the station is 44.93 square miles.

Moncure station on Haw River was abandoned January 1, 1900. A measurement was made on June 28 , however, when the gage read 2.68 feet; the area of the section was 611 square feet, the mean velocity 1.25 feet per second, and the discharge 769 second-feet. Discharge measurements for 1898 and 1899 will be found in the Twenty-first Annual Report, Part IV, page 115.

Moncure station on Deep River was also abandoned January 1, 1900. Measurement was made on June 27, when the gage read 3.67 feet; the area of section was 600 square feet, the mean velocity 1.14 feet per second, and the discharge 687 second-feet. Measurements for 1898 and 1899 will be found in the Twenty-first Annual Report, Part IV, page 117.

Records of flow during 1899 will be found in the Twenty-first Annual Report, Part IV, page 119. During 1900 the following measurements were made by E. W. Myers:

February 9: Gage height, 6.90 feet; discharge, 3,748 second-feet.

April 12: Gage height, 6.10 feet; discharge, 2,686 second-feet.

April 25: Gage height, 25.30 feet; discharge, 13,479 second-feet.

May 17: Gage height, 3.80 fe日t; discharge, 1,596 second-feet.

June 29: Gage height, 5.80 feet; discharge, 2,331 second-feet.

August 11: Gage height, 0.70 foot; discharge, 415 second-feet.

November 3: Gage height, 0.75 foot; discharge, 416 second-feet. 
Daily gage height, in feet, of Cape Fear River at Fayetteville, North Carolina, for 1900.

\begin{tabular}{|c|c|c|c|c|c|c|c|c|c|c|c|c|}
\hline Day. & Jan. & Feb. & Mar. & Apr. & May. & June. & July. & Aug. & Sept. & Oct. & Nov. & Dec. \\
\hline $\begin{array}{l}27 \\
28 \\
29 \\
30 \\
31\end{array}$ & $\begin{array}{r}5.0 \\
4.9 \\
4.2 \\
4.4 \\
4.2 \\
4.4 \\
4.2 \\
4.1 \\
3.9 \\
3.9 \\
4.8 \\
9.0 \\
21.3 \\
21.0 \\
17.3 \\
12.0 \\
9.1 \\
7.5 \\
6.5 \\
7.7 \\
12.5 \\
14.0 \\
11.7 \\
8.0 \\
7.1 \\
6.5 \\
6.1 \\
5.6 \\
5.7 \\
5.5 \\
5.3\end{array}$ & \begin{tabular}{|r}
5.2 \\
5.0 \\
4.6 \\
4.4 \\
5.3 \\
$i .5$ \\
10.0 \\
8.0 \\
6.4 \\
7.0 \\
10.0 \\
20.8 \\
25.7 \\
36.0 \\
35.8 \\
30.0 \\
24.7 \\
18.4 \\
13.7 \\
9.0 \\
8.2 \\
9.1 \\
23.0 \\
23.0 \\
17.5 \\
21.0 \\
19.0 \\
14.1 \\
\hdashline$\ldots .$. \\
$\ldots \ldots .$. \\
\end{tabular} & $\begin{array}{r}12.0 \\
27.0 \\
33.7 \\
29.0 \\
22.3 \\
15.0 \\
11.7 \\
9.7 \\
10.0 \\
23.0 \\
19.0 \\
1 \% .2 \\
14.3 \\
10.4 \\
8.7 \\
9.8 \\
19.0 \\
19.0 \\
15.0 \\
12.4 \\
10.0 \\
9.4 \\
8.5 \\
7.6 \\
7.0 \\
9.8 \\
14.0 \\
14.0 \\
11.6 \\
9.8 \\
9.6\end{array}$ & $\begin{array}{r}9.0 \\
7.7 \\
6.9 \\
6.7 \\
9.1 \\
10.0 \\
9.2 \\
6.7 \\
6.0 \\
5.8 \\
5.8 \\
5.6 \\
18.0 \\
18.0 \\
14.4 \\
10.2 \\
7.0 \\
6.0 \\
68.0 \\
38.0 \\
44.0 \\
44.0 \\
38.0 \\
33.0 \\
26.0 \\
22.0 \\
17.0 \\
12.2 \\
10.0 \\
8.3\end{array}$ & $\begin{array}{r}8.3 \\
9.7 \\
7.3 \\
6.9 \\
6.4 \\
5.6 \\
5.3 \\
5.0 \\
5.0 \\
4.9 \\
5.5 \\
5.5 \\
5.0 \\
4.7 \\
4.0 \\
3.8 \\
3.8 \\
3.6 \\
8.0 \\
18.0 \\
14.0 \\
10.4 \\
7.0 \\
5.4 \\
5.7 \\
5.5 \\
5.5 \\
5.0 \\
4.5 \\
4.0 \\
3.7\end{array}$ & $\begin{array}{r}3.2 \\
3.2 \\
3.0 \\
2.8 \\
2.8 \\
2.7 \\
2.7 \\
2.6 \\
3.5 \\
3.9 \\
4.2 \\
4.2 \\
3.0 \\
2.6 \\
2.5 \\
3.0 \\
2.7 \\
5.5 \\
14.0 \\
8.0 \\
5.7 \\
4.4 \\
4.0 \\
12.0 \\
17.4 \\
16.0 \\
13.7 \\
8.0 \\
5.5 \\
5.0\end{array}$ & $\begin{array}{r}5.0 \\
4.3 \\
4.0 \\
3.5 \\
3.1 \\
3.6 \\
3.1 \\
3.1 \\
2.65 \\
2.2 \\
1.8 \\
1.6 \\
1.4 \\
1.8 \\
5.0 \\
3.0 \\
2.5 \\
2.0 \\
1.7 \\
1.5 \\
1.3 \\
1.1 \\
1.0 \\
9.9 \\
3.5 \\
3.8 \\
4.5 \\
12.0 \\
9.0 \\
5.8 \\
4.6\end{array}$ & $\begin{array}{r}2.6 \\
2.8 \\
2.2 \\
1.8 \\
1.8 \\
1.4 \\
1.4 \\
1.2 \\
.9 \\
.8 \\
.7 \\
.7 \\
.7 \\
.8 \\
.6 \\
4.5 \\
3.9 \\
2.8 \\
2.4 \\
1.7 \\
1.6 \\
3.5 \\
2.2 \\
2.3 \\
1.7 \\
1.2 \\
.9 \\
1.9 \\
1.1\end{array}$ & $\begin{array}{r}5.0 \\
4.5 \\
3.8 \\
2.5 \\
1.8 \\
1.2 \\
.8 \\
.7 \\
.6 \\
.4 \\
.6 \\
.5 \\
.3 \\
.4 \\
.5 \\
2.1 \\
10.4 \\
8.4 \\
4.6 \\
3.2 \\
2.1 \\
1.7 \\
1.4 \\
1.3 \\
1.0 \\
.9 \\
.8 \\
1.3 \\
1.0 \\
1.1\end{array}$ & $\begin{array}{r}0.9 \\
.8 \\
.7 \\
.9 \\
1.2 \\
1.0 \\
.87 \\
.7 \\
.9 \\
.8 \\
1.8 \\
1.6 \\
1.3 \\
1.4 \\
2.9 \\
2.7 \\
1.9 \\
1.6 \\
1.2 \\
.0 \\
.98 \\
.8 \\
.7 \\
.7 \\
.8 \\
.6 \\
.7\end{array}$ & $\begin{array}{r}0.6 \\
.5 \\
.7 \\
2.5 \\
12.5 \\
10.5 \\
7.0 \\
5.2 \\
4.0 \\
3.4 \\
2.9 \\
2.5 \\
2.4 \\
2.0 \\
1.9 \\
2.0 \\
1.8 \\
1.5 \\
1.3 \\
1.1 \\
1.0 \\
1.1 \\
1.1 \\
1.1 \\
1.1 \\
1.5 \\
1.5 \\
2.5 \\
3.2 \\
3.1\end{array}$ & $\begin{array}{r}2.8 \\
2.2 \\
2.1 \\
2.3 \\
14.0 \\
15.0 \\
9.2 \\
8.4 \\
6.5 \\
4.8 \\
4.0 \\
3.5 \\
3.4 \\
3.3 \\
3.3 \\
3.4 \\
3.1 \\
3.0 \\
3.0 \\
2.6 \\
4.0 \\
1.8 \\
1.6 \\
11.4 \\
9.8 \\
7.0 \\
5.6 \\
4.4 \\
4.0 \\
4.4 \\
6.2\end{array}$ \\
\hline
\end{tabular}

YADKIN RIVER AT SILOAM, NORTH CAROLINA.

On August 2, 1900, a temporary station was established on Yadkin River at Siloam, North Carolina, by Cleveland Abbe, jr., and N. C. Curtis. Many miscellaneous measurements were also made on the upper tributaries of the Yadkin in connection with the general hydrographic study of the southern Appalachian region, records of which will be found in Water-Supply Paper No. 49.

The gaging station at Siloam is located on the north bank of the river, in a clump of overhanging trees, 50 yards above Hall's ferry and one-third of a mile south of the Siloam station, on the Wilkesboro division of the Southern Railroad. The gage rod, which is graduated to feet and tenths, is securely braced in a clump of trees. The gage is referred to a bench mark on the south bank in a clump of three sycamores at the water's edge, 25 feet above the ferry landing. A notch cut on the outermost tree is 8 feet from the root, and the bench mark is the top of the knot opposite this notch. The reading of the gage on August 2, 1900, was 2.7 feet, equal to 9.6 feet on the old gage, referred to the bench mark across the river, measuring to the surface of the water. The river is said to rise not more than 9 feet in ordinary freshets, but in 1898, as shown by flood marks and according to verbal accounts, it must have risen to about 16 feet on the present gage. The initial point of sounding is on the right bank, at the outer edge of the first stake on the upstream side of the rod. The banks are high and rarely are submerged. The bed of the stream is 
gravel and sand, slightly shifting. The drainage area of the river at this station is 1,219 square miles. The observer is C. E. Scott, of Siloam. During 1900 the following measurements were made by N. C. Curtis:

July 11: Gage height, 2.9 feet; discharge, 1,367 second.feet. August 3: Gage height, 2.6 feet; discharge, 1,218 second-feet.

October 31: Gage height, 3.1 feet; discharge, 1,469 second-feet.

Daily gage height, in feet, of Yadkin River at Siloam, North Carolina, for 1900.

\begin{tabular}{|c|c|c|c|c|c|c|c|c|c|c|c|}
\hline Day. & Aug. & Sept. & Oct. & Nov. & Dec. & Day. & Ang. & Sept. & Oct. & Nov. & Dec. \\
\hline $\begin{array}{r}1 \\
2 \\
3 \\
4 \\
5 \\
7 \\
8\end{array}$ & $\begin{array}{l}2.10 \\
2.05 \\
1.90 \\
1.95 \\
1.90 \\
1.90 \\
1.80 \\
1.80 \\
1.80 \\
1.85 \\
2.05 \\
2.10 \\
2.10\end{array}$ & $\begin{array}{l}2.00 \\
2.00 \\
2.00 \\
2.00 \\
2.00 \\
2.00 \\
2.00 \\
2.00 \\
2.00 \\
2.00 \\
2.00 \\
2.00 \\
2.00 \\
2.05 \\
2.20 \\
(a)\end{array}$ & $\begin{array}{l}2.10 \\
2.10 \\
2.20 \\
2.20 \\
2.30 \\
2.30 \\
2.30 \\
2.40 \\
2.30 \\
2.30 \\
2.30 \\
2.30 \\
2.60 \\
2.40 \\
2.30 \\
2.30\end{array}$ & $\begin{array}{l}2.50 \\
2.50 \\
2.80 \\
2.60 \\
2.40 \\
2.40 \\
2.40 \\
2.50 \\
2.50 \\
2.40 \\
2.40 \\
2.40 \\
2.40 \\
2.40 \\
2.40 \\
2.50\end{array}$ & $\begin{array}{l}2.60 \\
2.60 \\
2.70 \\
2.70 \\
2.60 \\
2.60 \\
2.60 \\
2.60 \\
2.60 \\
2.70 \\
2.70 \\
2.70 \\
2.60 \\
2.60 \\
2.60 \\
2.60\end{array}$ & 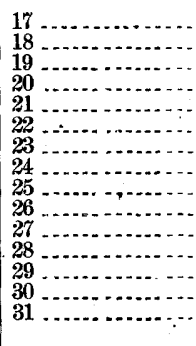 & $\begin{array}{l}2.10 \\
2.10 \\
2.10 \\
2.10 \\
2.60 \\
3.05 \\
2.95 \\
3.00 \\
2.90 \\
2.75 \\
2.70 \\
2.00 \\
2.00 \\
2.00 \\
2.00\end{array}$ & $\begin{array}{l}(a) \\
(a) \\
(a) \\
(a) \\
(a) \\
(a) \\
(a) \\
(a) \\
(a) \\
(a) \\
(a) \\
(a) \\
(a) \\
(a)\end{array}$ & $\begin{array}{l}2.30 \\
2.30 \\
2.30 \\
2.30 \\
2.30 \\
2.60 \\
3.10 \\
11.20 \\
4.50 \\
3.60 \\
3.40 \\
3.20 \\
2.60 \\
2.60 \\
2.60\end{array}$ & $\begin{array}{r}2.50 \\
2.50 \\
2.50 \\
2.50 \\
2.60 \\
2.60 \\
2.50 \\
2.50 \\
2.80 \\
11.30 \\
10.80 \\
10.60 \\
9.00 \\
2.80\end{array}$ & $\begin{array}{l}2.60 \\
2.60 \\
2.60 \\
2.60 \\
2.70 \\
2.70 \\
2.70 \\
2.70 \\
2.60 \\
2.60 \\
2.70 \\
2.70 \\
2.70 \\
3.10 \\
3.20\end{array}$ \\
\hline
\end{tabular}

$a$ No record.

YADKIN RIVER AT SALISBURY, NORTH CAROLINA.

This station is described in Water-Supply Paper No. 36, page 116. Owing to the inconvenient location of the railroad bridge from which the measurements were made and its height above the water, the gaging station was moved June 1, 1899, to the new iron highway bridge about 300 yards above the railroad bridge, the new gage reading the same as the old. In its new position the 10-foot mark on the rod is opposite the center of the first strut from the west end of the second span from the west end of the bridge, on the downstream side. The rod is of pine, 3 inches wide, well painted, graduated to feet and tenths, and securely nailed to the inner surface of the guard rail, the top of the rod being flush with the top of the rail. The distance between the zero of the rod and the outer rim of the pulley is 2.13 feet, and between the end of the weight and the pointer on the wire 26.75 feet. The observer is J. T. Yarbrough, keeper of the bridge. The stream here is about the same width as at the railroad bridge, and the section is a fairly good one for gaging purposes, the bottom for the greater part of the width of the stream being hard and rocky. At times the current is very materially modified by large quantities of driftwood lodging against the piers, but it is thought better results can be obtained than at the old station. Although this stream is subject to periods of comparatively low flow, the minimum run-off is large. The lowest recorded flow was 900 second-feet, occurring in September and October, 1897. The highest flood of which there is any record occurred on March 20, 
1899, the gage height being 18.80 feet and the measured discharge 115,000 cubic feet per second, showing the maximum discharge to be nearly 128 times the minimum discharge.

Records of flow during 1899 will be found in the Twenty-first Annual Report, Part IV, page 120. During 1900 the following measurements were made by E. W. Myers:

February 13: Gage height, 7.43 feet; discharge, 26,682 second-feet.

April 14: Gage height, 2.50 feet; discharge, 3,962 second-feet.

May 19: Trage height, 2.45 feet; discharge, 4,042 second-feet.

May 25: Gage height, 3.82 feet; discharge, 7,930 second-feet.

August 18: Gage height, 1.95 feet; discharge, 1,447 second feet.

November 9: Gage height, 2.30 feet; discharge, 2,095 second-feet.

December 17: Gage height, 2.45 feet; discharge, 3,025 second-feet.

Daily gage height, in feet, of Yadkin River at Salisbury, North Carolina, for 1900.

\begin{tabular}{|c|c|c|c|c|c|c|c|c|c|c|c|c|}
\hline Day. & Jan. & Feb. & Mar. & Apr. & May. & June. & July. & Aug. & Sept. & Oct. & Nov. & Dec. \\
\hline $\begin{array}{l}26 \\
28 \\
29 \\
30 \\
31\end{array}$ & $\begin{array}{l}1.50 \\
1.50 \\
1.60 \\
1.60 \\
1.60 \\
1.60 \\
2.60 \\
2.10 \\
2.20 \\
2.30 \\
2.50 \\
4.30 \\
-3.90 \\
3.00 \\
2.50 \\
2.30 \\
2.30 \\
2.30 \\
4.90 \\
5.50 \\
4.90 \\
3.60 \\
2.60 \\
2.40 \\
2.90 \\
2.30 \\
2.20 \\
2.20 \\
2.00 \\
1.90\end{array}$ & $\begin{array}{l}1.50 \\
1.50 \\
1.50 \\
1.70 \\
2.80 \\
2.70 \\
2.50 \\
2.30 \\
2.30 \\
2.90 \\
3.90 \\
4.10 \\
6.00 \\
9.10 \\
6.00 \\
4.10 \\
3.20 \\
2.80 \\
2.40 \\
2.40 \\
5.60 \\
6.30 \\
4.30 \\
3.80 \\
2.50 \\
2.90 \\
2.90\end{array}$ & $\begin{array}{l}4.60 \\
9.50 \\
6.90 \\
4.40 \\
3.50 \\
3.00 \\
2.90 \\
2.90 \\
4.30 \\
4.40 \\
4.20 \\
3.50 \\
3.30 \\
3.00 \\
2.70 \\
4.50 \\
6.10 \\
4.60 \\
4.60 \\
3.70 \\
4.60 \\
3.80 \\
3.20 \\
3.00 \\
2.80 \\
3.90 \\
3.80 \\
3.40 \\
3.00 \\
2.90 \\
2.80\end{array}$ & \begin{tabular}{|c}
2.60 \\
2.60 \\
2.50 \\
2.60 \\
2.50 \\
2.40 \\
2.30 \\
2.30 \\
2.30 \\
2.20 \\
2.20 \\
2.50 \\
2.70 \\
2.60 \\
2.00 \\
2.40 \\
2.30 \\
2.30 \\
9.95 \\
10.60 \\
6.00 \\
7.00 \\
6.70 \\
4.50 \\
3.90 \\
3.50 \\
3.30 \\
3.10 \\
2.90 \\
2.70
\end{tabular} & $\begin{array}{l}2.70 \\
2.60 \\
2.50 \\
2.50 \\
2.40 \\
2.40 \\
2.40 \\
2.30 \\
2.40 \\
2.40 \\
2.30 \\
2.30 \\
2.30 \\
2.30 \\
2.10 \\
2.10 \\
2.10 \\
2.40 \\
2.50 \\
2.40 \\
2.30 \\
2.10 \\
2.10 \\
2.10 \\
4.00 \\
3.20 \\
2,70 \\
2.30 \\
2.30 \\
2.10 \\
2.10 \\
2.10 \\
\end{array}$ & $\begin{array}{l}2.37 \\
2.40 \\
2.30 \\
2.50 \\
2.50 \\
2.41 \\
2.44 \\
.37 \\
2.55 \\
2.55 \\
.40 \\
2.30 \\
2.30 \\
2.70 \\
2.85 \\
2.65 \\
4.78 \\
4.54 \\
4.52 \\
3.47 \\
2.95 \\
2.65 \\
3.57 \\
7.00 \\
4.68 \\
4.40 \\
4.35 \\
3.45 \\
3.55 \\
3.50\end{array}$ & $\begin{array}{l}2.90 \\
2.73 \\
2.55 \\
2.50 \\
2.45 \\
2.50 \\
2.30 \\
2.40 \\
2.35 \\
2.35 \\
2.25 \\
2.25 \\
2.25 \\
2.25 \\
2.50 \\
2.40 \\
2.22 \\
2.15 \\
2.00 \\
1.90 \\
2.00 \\
2.00 \\
2.45 \\
2.30 \\
2.65 \\
2.65 \\
2.65 \\
3.35 \\
3.05 \\
2.55 \\
2.30 \\
2.20\end{array}$ & $\begin{array}{l}2.35 \\
2.20 \\
2.10 \\
2.10 \\
2.20 \\
1.95 \\
1.95 \\
1.95 \\
1.95 \\
1.95 \\
1.90 \\
1.85 \\
1.85 \\
1.80 \\
2.00 \\
1.85 \\
1.90 \\
2.00 \\
1.90 \\
1.85 \\
1.85 \\
1.90 \\
2.60 \\
3.05 \\
2.25 \\
2.30 \\
2.10 \\
2.00 \\
1.90 \\
1.90 \\
2.05\end{array}$ & $\begin{array}{l}2.10 \\
1.90 \\
1.90 \\
1.90 \\
1.90 \\
1.85 \\
1.80 \\
1.75 \\
1.75 \\
1.70 \\
1.85 \\
1.70 \\
1.65 \\
1.65 \\
1.65 \\
4.10 \\
4.95 \\
2.80 \\
2.20 \\
2.00 \\
2.00 \\
2.00 \\
2.25 \\
2.10 \\
2.00 \\
1.90 \\
1.90 \\
1.90 \\
.1 .90 \\
1.75\end{array}$ & $\begin{array}{l}2.60 \\
2.10 \\
1.90 \\
1.90 \\
2.00 \\
2.20 \\
2.10 \\
2.10 \\
2.30 \\
2.60 \\
2.20 \\
2.05 \\
2.05 \\
2.10 \\
2.05 \\
2.20 \\
2.10 \\
2.00 \\
2.00 \\
2.00 \\
1.90 \\
2.00 \\
2.00 \\
4.55 \\
6.81 \\
3.45 \\
2.90 \\
2.60 \\
2.50 \\
2.30 \\
2.35\end{array}$ & $\begin{array}{l}2.30 \\
2.30 \\
2.30 \\
2.70 \\
3.05 \\
2.75 \\
2.40 \\
2.30 \\
2.30 \\
2.20 \\
2.25 \\
2.30 \\
2.20 \\
2.20 \\
2.15 \\
2.15 \\
2.15 . \\
2.15 \\
2.15 \\
2.20 \\
2.35 \\
2.30 \\
2.25 \\
2.20 \\
2.20 \\
4.08 \\
7.85 \\
3.90 \\
3.20 \\
2.80\end{array}$ & $\begin{array}{l}2.70 \\
2.60 \\
2.50 \\
3.60 \\
6.63 \\
4.80 \\
3.55 \\
3.10 \\
2.80 \\
2.65 \\
2.50 \\
2.50 \\
2.50 \\
2.50 \\
2.45 \\
2.47 \\
2.40 \\
2.35 \\
2.40 \\
2.40 \\
2.70 \\
3.30 \\
3.30 \\
3.30 \\
3.20 \\
2.90 \\
2.70 \\
2.60 \\
2.55 \\
2.55 \\
3.25\end{array}$ \\
\hline
\end{tabular}

YADKIN RIVER AT NORWOOD, NORTH CAROLINA.

This station was abandoned January 1, 1900, and no measurements have been made since that date. A description of the station and records of discharge measurements will be found in Water-Supply Paper No. 36, page 118; also in the Twenty-first Annual Report, Part IV, page 121.

\section{CATAWBA RIVER NEAR MORGANTON, NORTH CAROLINA.}

During the summer of 1900 a hydrographic investigation was made of the southern Appalachian region. For the purpose of the study, temporary stations were established on Catawba River near Morganton, 
on John River near Morganton, and on Linville River near Bridgewater. Many miscellaneous measurements were also made on the headwaters of the Catawba and its tributaries, as well as of other streams, records of which will be found in Water-Supply Paper No. 49.

The Morganton station was established June 19, 1900, at the highway bridge near Morganton, on the road from Morganton to Hartland. The wire gage is suspended from the bridge, and is read on a horizontal scale graduated to feet and tenths and nailed on the guard rail. The river is straight for a distance of 200 feet above and below the station: The banks are high and have never overflowed. The highest flood of the Catawba rose to the floor of the bridge at this station, a height of about 28 feet. The bed is silt and mud and shifts slightly during floods. The drainage area is 757.8 square miles. Upper Creek flows into the Catawba about 200 feet above the station. The observer is J. W. Kincaid, a farmer living about 200 yards from the station. During 1900 the following measurements were made:

June 13: Gage height, 1.33 feet; discharge, 1,393 second-feet.

June 18: Gage height, 2.50 feet; discharge, 4,030 second-feet.

July 6: Gage height, 1.30 feet; discharge, 1,164 second-feet.

August 8: Gage height, 0.60 foot; discharge, 558 second-feet.

September 24: Gage height, 0.50 foot; discharge, 525 second-feet.

November $\tau$ : Gage height, 1.50 feet; discharge, 1,374 second-feet.

Daily gage height, in feet, of Catawba River near Morganton, North Carolina, for 1900 .

\begin{tabular}{|c|c|c|c|c|c|c|c|}
\hline Day. & June. & July. & Aug. & Sept. & Oct. & Nov. & Dec. \\
\hline (19 & $\begin{array}{l}\cdots \\
\cdots \\
2.50 \\
1.60 \\
1.60 \\
3.37 \\
3.05 \\
3.87 \\
3.60 \\
3.00 \\
2.30 \\
2.28 \\
1.95 \\
1.70\end{array}$ & $\begin{array}{l}1.53 \\
1.78 \\
1.60 \\
1.48 \\
1.43 \\
1.30 \\
1.23 \\
1.20 \\
1.10 \\
1.50 \\
1.00 \\
1.25 \\
1.00 \\
.95 \\
.90 \\
.87 \\
.83 \\
.85 \\
.87 \\
.83 \\
.90 \\
1.23 \\
1.25 \\
2.63 \\
1.05 \\
1.10 \\
1.45 \\
1.43\end{array}$ & $\begin{array}{l}0.97 \\
.83 \\
.78 \\
.75 \\
.75 \\
.70 \\
.70 \\
.65 \\
.63 \\
.60 \\
.58 \\
.57 \\
.65 \\
.65 \\
.63 \\
.55 \\
.63 \\
.63 \\
.53 \\
.45 \\
.45 \\
.65 \\
.73 \\
.58 \\
.80 \\
.60 \\
.63 \\
.53 \\
.55 \\
.60 \\
.55\end{array}$ & $\begin{array}{r}0.60 \\
.55 \\
.60 \\
.53 \\
.55 \\
.50 \\
.45 \\
.50 \\
.45 \\
.45 \\
.33 \\
.35 \\
.33 \\
1.55 \\
2.50 \\
.15 \\
1.25 \\
1.15 \\
.80 \\
.68 \\
.63 \\
.43 \\
.55 \\
.53 \\
.55 \\
.53 \\
.53 \\
.48 \\
.55 \\
.53\end{array}$ & $\begin{array}{r}0.50 \\
.50 \\
.58 \\
1.00 \\
1.20 \\
1.10 \\
.80 \\
.85 \\
.80 \\
.75 \\
.65 \\
.60 \\
.55 \\
.58 \\
.53 \\
.53 \\
.53 \\
.53 \\
.53 \\
.53 \\
.50 \\
.50 \\
8.55 \\
6.48 \\
4.15 \\
2.95 \\
1.80 \\
1.60 \\
1.60 \\
1.40 \\
1.35\end{array}$ & $\begin{array}{l}1.25 \\
1.25 \\
2.70 \\
1.70 \\
1.45 \\
1.70 \\
1.55 \\
1.25 \\
1.35 \\
1.20 \\
1.20 \\
1.20 \\
1.10 \\
1.25 \\
1.25 \\
1.25 \\
1.25 \\
1.00 \\
1.50 \\
1.25 \\
1.00 \\
1.50 \\
1.95 \\
1.50 \\
1.90 \\
4.30 \\
3.20 \\
2.30 \\
1.60 \\
1.52\end{array}$ & 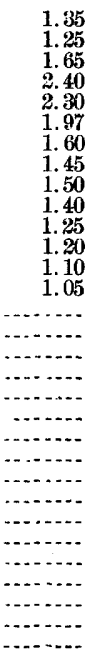 \\
\hline
\end{tabular}




\section{LINVILLE RIVER NEAR BRIDGEWATER, NORTH CAROLINA.}

This station, one of the temporary stations established in connection with the hydrographic investigations of the southern Appalachian region, was established July 3, 1900. It is located at Poole's mill, just above the ford on the road between Morganton and Marion. The gage is near the tailrace of the mill, and the gagings are made about 200 feet farther down. The bed is extremely rough and rocky, the current being swift during high water. There are no bridges across this stream, and high-water measurements are therefore.difficult to obtain. The bench mark is a cross cut on the rocky cliff on the left bank of the stream. The initial point of sounding is at the end of a log sunk in the sandy right bank. The drainage area at this station is 86.2 square miles. The observer is J. A. Cooper, miller. The following measurements were made during 1900 :

June 14: Gage height, 9.92 feet; discharge, 104 second-feet. July 3: Gage height, 9.54 feet; discharge, 216 second-feet.

July 10: Gage height, 9.90 feet; discharge, 116 second-feet.

August 17: Gage height, 10.15 feet; discharge, 78 second-feet.

September 21: Gage height, 9.8 feet; discharge, 55 second-feet.

Daily gage height, in feet, of Linville River near Bridgewater, North Carolina, for 1900 .

\begin{tabular}{|c|c|c|c|c|c|c|c|c|c|}
\hline Day. & July. & Aug. & Sept. & Oet. & Day. & July. & Aug. & Sept. & Oct. \\
\hline $\begin{array}{c}1 \\
1 \\
3 \\
4 \\
5 \\
6\end{array}$ & $\begin{array}{l}0.54 \\
9.54 \\
9.46 \\
9.58 \\
9.54 \\
9.63 \\
9.58 \\
9.71 \\
9.58 \\
9.65 \\
9.67 \\
9.63 \\
9.67 \\
9.71 \\
9.67\end{array}$ & $\begin{array}{r}9.83 \\
9.92 \\
9.88 \\
9.83 \\
9.92 \\
10.08 \\
10.00 \\
10.08 \\
10.08 \\
10.08 \\
10.08 \\
10.08 \\
10.08 \\
10.13 \\
10.08 \\
10.08\end{array}$ & $\begin{array}{l}10.17 \\
10.17 \\
10.21 \\
10.21 \\
10.25 \\
10.25 \\
10.25 \\
10.29 \\
10.29 \\
10.29 \\
10.29 \\
10.33 \\
10.33 \\
10.29 \\
10.21 \\
7.50\end{array}$ & \begin{tabular}{l}
9.75 \\
9.67 \\
9.58 \\
9.50 \\
9.58 \\
9.58 \\
9.63 \\
$\mathbf{9 . 6 3}$ \\
$\mathbf{9 . 6 3}$ \\
$\mathbf{9 . 6 3}$ \\
$\mathbf{9 . 5 8}$ \\
$\mathbf{9 . 5 0}$ \\
$\mathbf{9 . 5 4}$ \\
$\mathbf{9 . 5 4}$ \\
\hdashline-2
\end{tabular} & $\begin{array}{l}17 \\
18 \\
19 \\
20 \\
20 \\
21 \\
22\end{array}$ & $\begin{array}{r}9.83 \\
9.83 \\
10.04 \\
10.00 \\
9.75 \\
9.92 \\
9.92 \\
9.92 \\
9.83 \\
9.92 \\
9.75 \\
9.75 \\
9.92 \\
9.83 \\
9.92\end{array}$ & $\begin{array}{l}10.13 \\
10.13 \\
10.08 \\
10.08 \\
10.13 \\
10.17 \\
10.17 \\
10.17 \\
10.21 \\
10.17 \\
10.21 \\
10.21 \\
10.21 \\
10.21 \\
10.21\end{array}$ & $\begin{array}{r}9.67 \\
9.67 \\
10.00 \\
10.00 \\
9.92 \\
9.92 \\
9.92 \\
9.92 \\
10.00 \\
10.08 \\
10.08 \\
10.13 \\
9.75 \\
9.75 \\
\cdots\end{array}$ & 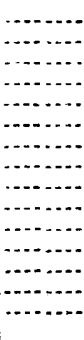 \\
\hline
\end{tabular}

JOHN RIVER NEAR MORGANTON, NORTH CAROLINA.

This station was established Jüne 17, 1900, by H. A. Pressey and E. W. Myers, at the highway bridge on the road from Morganton to Lenoir. A wire gage is suspended from the bridge, and the readings are made on a gage rod nailed to the guard rail on the downstream side of the bridge. The river channel is straight for 200 feet above and 300 feet below the station. The banks are high and the bed is rocky and permanent in section. The drainage area at this station is 212.8 square miles. The observer is W. A. Clontz, a farmer living 
about a third of a mile from the bridge. The following measurements were made during 1900 :

June 13: Gage height, 2.64 feet; discharge, 465 second-feet.

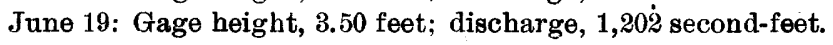

July 6: Gage height, 2.63 feet; discharge, 511 second-feet.

August 8: Gage height, 1.90 feet; discharge, 135 second-feet.

September 24: Gage height, 1.90 feet; discharge, 148 second-feet.

November 7: Gage height, 2.32 feet; discharge, 367 second-feet.

Daily gage height, in feet, of John River near Morganton, North Carolina, for 1900.

\begin{tabular}{|c|c|c|c|c|c|c|c|}
\hline Day. & June. & July. & Aug. & Sept. & Oct. & Nov. & Dec. \\
\hline${ }^{1}$ & \begin{tabular}{|r}
0 \\
\hdashline \\
\hdashline \\
\hdashline
\end{tabular} & $\begin{array}{l}2.60 \\
2.55 \\
2.58 \\
2.70 \\
2.58 \\
2.45 \\
2.38 \\
2.30 \\
2.25 \\
2.25 \\
2.30 \\
2.25 \\
2.15 \\
2.13 \\
2.10 \\
2.10 \\
2.15 \\
2.45 \\
2.10 \\
2.28 \\
2.35 \\
2.30 \\
2.23 \\
2.20 \\
2.20 \\
2.13\end{array}$ & 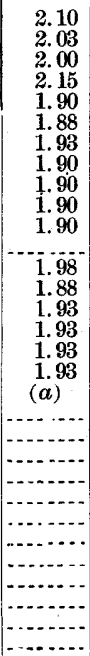 & $\begin{array}{r}\cdots \\
\hdashline \\
\hdashline \\
\hdashline\end{array}$ & \begin{tabular}{r}
1.80 \\
1.83 \\
1.93 \\
2.43 \\
2.38 \\
2.28 \\
2.10 \\
2.03 \\
1.93 \\
1.90 \\
1.90 \\
1.95 \\
1.90 \\
\hdashline 1.90 \\
1.88 \\
1.83 \\
1.78 \\
1.73 \\
1.73 \\
\hdashline 1.88 \\
14.72 \\
5.60 \\
3.45 \\
2.98 \\
2.70 \\
\hdashline 2.45 \\
2.30 \\
2.30
\end{tabular} & $\begin{array}{r}2.30 \\
2.30 \\
2.50 \\
2.60 \\
2.35 \\
2.35 \\
2.30 \\
2.25 \\
2.25 \\
2.20 \\
2.20 \\
2.15 \\
2.15 \\
2.10 \\
2.05 \\
2.12 \\
2.15 \\
2.12 \\
2.10 \\
2.08 \\
2.08 \\
4.55 \\
3.00 \\
2.65 \\
2.52 \\
2.42\end{array}$ & \begin{tabular}{r}
2.32 \\
\hdashline 2.32 \\
3.38 \\
3.20 \\
2.85 \\
2.67 \\
2.62 \\
\hdashline 2.50 \\
2.35 \\
2.32 \\
2.35 \\
2.30 \\
2.28 \\
\hdashline 2.25 \\
2.20 \\
2.18 \\
2.22 \\
3.08 \\
2.92 \\
0.78 \\
2.68 \\
2.48 \\
2.38 \\
2.32 \\
2.28 \\
-2.90
\end{tabular} \\
\hline
\end{tabular}

a No record from August 19 to September 9, inclusive.

CATAWBA RIVER AT CATAWBA, NORTH CAROLINA.

This station was originally established in July, 1896, but was abandoned December 31, 1899. On June 13, 1900, it was reestablished as a temporary station to assist in the study of the hydrography of the southern Appalachian region. The measurements are made from the Southern Railway bridge about a fourth of a mile east of the railway station. The wire gage is suspended from the bridge and is referred to the painted gage rod, which is divided into feet and ienths and nailed to the guard rail. The initial point of sounding is on the west end of the bridge. The channel is straight above and below the station, and the current is moderately swift. The banks are high, and the bed is composed of gravel and fine sand. The observer is C. A. Reed, jr., clerk in the post-office at Catawba. During 1900 the following measurements were made by E. W. Myers:

July 3: Gage height, 3.45 feet; discharge, 3,372 second-feet. August 14: Gage height, 2.10 feet; discharge, 914 second-feet.

November 7: Gage height, 2.95 feet; discharge, 2,083 second-feet.

December 18: Gage height, 2.59 feet; discharge, 2,139 second-feet. 
Daily gage height, in feet, of Catawba River at Catawba, North Carolina, for 1900.

\begin{tabular}{|c|c|c|c|c|c|c|c|}
\hline Day. & June. & July. & Aug. & Sept. & Oct. & Nov. & Dec. \\
\hline 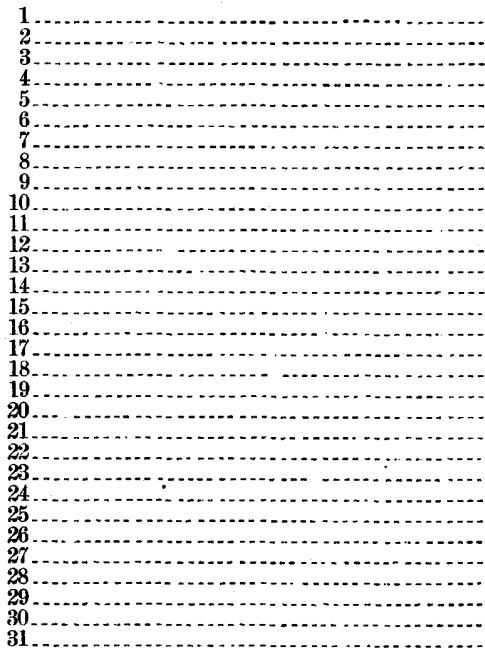 & $\begin{array}{r}2.35 \\
2.80 \\
3.15 \\
4.85 \\
8.65 \\
7.50 \\
5.05 \\
4.55 \\
3.45 \\
4.75 \\
6.14 \\
5.75 \\
5.65 \\
5.40 \\
4.15 \\
3.65 \\
3.45 \\
3.30 \\
\hdashline\end{array}$ & $\begin{array}{l}3.15 \\
2.65 \\
\text { 3. } 35 \\
3.15 \\
3.10 \\
3.00 \\
2.90 \\
2.90 \\
2.80 \\
2.75 \\
2.65 \\
2.60 \\
2.60 \\
2.55 \\
2.50 \\
2.50 \\
2.50 \\
2.50 \\
2.50 \\
2.50 \\
2.50 \\
2.50 \\
2.30 \\
2.70 \\
2.70 \\
3.25 \\
3.20 \\
2.90 \\
2.70 \\
2.70 \\
3.00\end{array}$ & $\begin{array}{l}2.80 \\
2.70 \\
2.55 \\
2.40 \\
2.40 \\
2.40 \\
2.40 \\
2.35 \\
2.30 \\
2.30 \\
2.30 \\
2.25 \\
2.25 \\
2.25 \\
(a) \\
(a) \\
(a) \\
(a) \\
(a) \\
(a) \\
(a) \\
(a) \\
(a) \\
(a) \\
(a) \\
(a) \\
(a) \\
(a) \\
(a) \\
(a) \\
(a)\end{array}$ & $\begin{array}{l}(a) \\
(a) \\
1.80 \\
1.72 \\
1.75 \\
1.90 \\
1.85 \\
1.80 \\
1.78 \\
1.72 \\
1.70 \\
1.75 \\
1.75 \\
1.65 \\
1.85 \\
5.00 \\
5.70 \\
4.40 \\
3.55 \\
3.10 \\
3.30 \\
3.55 \\
3.55 \\
3.55 \\
3.50 \\
3.45 \\
3.40 \\
3.38 \\
3.30 \\
3.40\end{array}$ & $\begin{array}{r}3.55 \\
3.60 \\
3.65 \\
3.70 \\
3.70 \\
4.20 \\
3.90 \\
3.85 \\
3.80 \\
3.75 \\
3.75 \\
3.75 \\
3.70 \\
3.60 \\
3.60 \\
3.60 \\
3.60 \\
3.65 \\
3.70 \\
3.65 \\
3.60 \\
3.75 \\
4.10 \\
20.20 \\
7.40 \\
5.70 \\
4.90 \\
4.70 \\
4.45 \\
4.35 \\
3.90\end{array}$ & $\begin{array}{l}3.70 \\
3.50 \\
3.10 \\
4.10 \\
3.20 \\
3.10 \\
3.10 \\
2.95 \\
2.75 \\
2.75 \\
2.75 \\
2.75 \\
2.75 \\
2.75 \\
2.70 \\
2.65 \\
2.60 \\
2.50 \\
2.55 \\
2.55 \\
2.60 \\
2.60 \\
2.50 \\
2.45 \\
3.60 \\
9.10 \\
5.00 \\
4.10 \\
3.60 \\
3.25\end{array}$ & $\begin{array}{l}2.85 \\
2.85 \\
3.40 \\
4.50 \\
4.10 \\
3.85 \\
3.45 \\
3.15 \\
3.00 \\
2.95 \\
2.95 \\
2.80 \\
2.85 \\
2.80 \\
2.70 \\
2.75 \\
2.75 \\
2.60 \\
2.60 \\
3.10 \\
4.85 \\
5.20 \\
4.75 \\
4.20 \\
3.80 \\
3.35 \\
3.15 \\
3.00 \\
3.10 \\
3.35 \\
4.05\end{array}$ \\
\hline
\end{tabular}

$a$ No record.

CATAWBA RIVER AT ROCKHILL, SOUTH CAROLINA.

This station, which is described in Water-Supply Paper No. 36, page 121, was established September 3, 1895. During the last year a dam has been constructed across the river about 6 miles above the gaging station, and it is probable that this will modify the flow to some extent, particularly at low stages. The maximum flood of which there is any record at this station occurred March 20, 1899, the water reaching a height of 17.25 feet on the gage, with a probable discharge of about 72,000 second-feet. The lowest stage of flow occurred in September of 1895 and 1896 , when a gage height of 1.0 foot was reached, the probable discharge being 1,300 second-feet. During 1900 the following measurements were made by $\mathrm{E}$. W. Myers:

February 21: Gage height, 2.63 feet; discharge, 3,803 second-feet.

February 2: Gage height, 5.28 feet; discharge, 16, 791 second-feet. April 13: Gage height, 2.75 feet; discharge, 4,703 second-feet. April 21: Gage height, 9.07 feet; discharge, 31,610 second-feet. May 21: Gage height, 2.42 feet; discharge, 3,703 second-feet July 4: Gage height, 2.86 feet; discharge, 5,623 second-feet. August 16: Gage height, 1.70 feet; discharge, 1,936 second-feet. October 26 : Gage height, 3.30 feet; discharge, 8,843 second-feet. 
Daily gage height, in feet, of Catawba River at Rockhill, South Carolina, for 1900.

\begin{tabular}{|c|c|c|c|c|c|c|c|c|c|c|c|c|}
\hline Day. & Jan. & Feb. & Mar. & Apr. & May. & June. & July. & Aug. & Sept. & Oct. & Nov. & Dec. \\
\hline n & $\begin{array}{l}1.80 \\
1.80 \\
2.70 \\
2.70 \\
2.30 \\
2.20 \\
2.00 \\
2.00 \\
2.00 \\
2.00 \\
1.90 \\
3.20 \\
4.70 \\
3.59 \\
2.80 \\
2.50 \\
2.40 \\
2.20 \\
2.00 \\
2.90 \\
3.30 \\
3.20 \\
2.70 \\
2.50 \\
2.40 \\
2.40 \\
2.30 \\
2.20 \\
2.10 \\
2.10 \\
2.10\end{array}$ & $\begin{array}{r}2.10 \\
2.00 \\
2.09 \\
2.10 \\
2.20 \\
2.40 \\
2.40 \\
2.00 \\
2.00 \\
2.60 \\
3.80 \\
3.80 \\
6.30 \\
1.30 \\
7.50 \\
4.30 \\
3.40 \\
3.00 \\
2.90 \\
2.60 \\
2.60 \\
4.90 \\
5.40 \\
4.00 \\
3.40 \\
3.30 \\
3.00 \\
2.80\end{array}$ & $\begin{array}{l}4.60 \\
11.90 \\
7.90 \\
4.50 \\
3.70 \\
3.30 \\
3.10 \\
3.00 \\
3.80 \\
4.10 \\
3.70 \\
3.40 \\
3.20 \\
3.10 \\
2.90 \\
5.80 \\
6.70 \\
4.50 \\
3.60 \\
3.30 \\
3.80 \\
3.70 \\
3.30 \\
2.30 \\
2.90 \\
3.10 \\
3.70 \\
3.50 \\
3.20 \\
3.10 \\
3.00\end{array}$ & $\begin{array}{c}2.80 \\
2.70 \\
2.60 \\
2.50 \\
2.80 \\
2.80 \\
2.60 \\
2.60 \\
2.60 \\
2.50 \\
2.50 \\
2.20 \\
2.70 \\
2.60 \\
2.50 \\
2.50 \\
2.50 \\
2.40 \\
10.00 \\
(a) \\
(a) \\
(a) \\
(a) \\
(a) \\
(a) \\
(a) \\
(a) \\
\text { (a) } \\
(a) \\
\text { (a) }\end{array}$ & $\begin{array}{l}(a) \\
(a) \\
(a) \\
(a) \\
(a) \\
(a) \\
(a) \\
(a) \\
(a) \\
(a) \\
(a) \\
2 a \\
2.40 \\
2.30 \\
2.30 \\
2.30 \\
2.30 \\
2.25 \\
2.30 \\
4.60 \\
2.60 \\
2.40 \\
2.20 \\
2.20 \\
2.20 \\
3.40 \\
3.60 \\
2.80 \\
2.60 \\
2.50 \\
2.40 \\
2.30\end{array}$ & $\begin{array}{l}2.30 \\
2.30 \\
2.20 \\
2.50 \\
2.50 \\
2.40 \\
2.30 \\
2.30 \\
2.40 \\
2.40 \\
2.40 \\
2.30 \\
2.20 \\
2.20 \\
2.60 \\
2.55 \\
3.90 \\
6.75 \\
6.30 \\
4.40 \\
3.30 \\
2.90 \\
5.80 \\
6.50 \\
5.00 \\
4.90 \\
4.00 \\
3.50 \\
3.20 \\
3.10\end{array}$ & $\begin{array}{l}3.00 \\
2.90 \\
2.80 \\
2.80 \\
2.50 \\
2.40 \\
2.40 \\
2.30 \\
2.20 \\
2.20 \\
2.20 \\
2.10 \\
2.10 \\
2.10 \\
2.10 \\
2.10 \\
2.10 \\
2.10 \\
2.10 \\
2.00 \\
1.90 \\
1.90 \\
2.10 \\
2.60 \\
2.60 \\
2.20 \\
2.30 \\
2.50 \\
2.30 \\
2.90 \\
2.20 \\
2.90\end{array}$ & $\begin{array}{l}2.20 \\
2.10 \\
2.00 \\
1.90 \\
1.90 \\
1.80 \\
1.80 \\
1.80 \\
1.80 \\
1.80 \\
1.70 \\
1.70 \\
1.70 \\
1.70 \\
1.70 \\
1.70 \\
2.00 \\
2.00 \\
1.90 \\
1.90 \\
1.70 \\
1.60 \\
2.30 \\
2.10 \\
1.80 \\
2.00 \\
1.90 \\
1.80 \\
1.80 \\
2.00 \\
1.80\end{array}$ & $\begin{array}{l}1.80 \\
1.80 \\
1.80 \\
1.80 \\
1.70 \\
1.70 \\
1.70 \\
1.70 \\
1.60 \\
1.50 \\
1.50 \\
1.50 \\
1.50 \\
1.60 \\
1.60 \\
3.20 \\
2.70 \\
2.10 \\
1.80 \\
1.80 \\
1.70 \\
1.70 \\
1.40 \\
1.30 \\
1.30 \\
1.30 \\
1.30 \\
1.30\end{array}$ & $\begin{array}{r}1.40 \\
1.40 \\
1.40 \\
1.40 \\
1.40 \\
1.40 \\
1.70 \\
1.70 \\
1.80 \\
1.60 \\
1.60 \\
1.60 \\
1.60 \\
1.50 \\
1.50 \\
1.50 \\
1.50 \\
1.40 \\
1.40 \\
1.40 \\
1.40 \\
7.75 \\
1.30 \\
3.40 \\
2.50 \\
2.20 \\
2.10 \\
2.00 \\
2.00\end{array}$ & $\begin{array}{l}1.90 \\
1.80 \\
1.80 \\
3.40 \\
3.00 \\
2.50 \\
2.10 \\
2.00 \\
2.00 \\
1.90 \\
1.80 \\
1.70 \\
1.70 \\
1.70 \\
1.70 \\
1.70 \\
1.70 \\
1.70 \\
1.70 \\
1.70 \\
1.70 \\
1.70 \\
1.70 \\
1.70 \\
1.70 \\
1.80 \\
6.10 \\
3.90 \\
2.60 \\
2.30\end{array}$ & $\begin{array}{l}2.20 \\
2.00 \\
2.00 \\
3.20 \\
4.20 \\
4.10 \\
2.90 \\
2.40 \\
2.20 \\
2.20 \\
2.20 \\
2.20 \\
2.00 \\
1.90 \\
1.90 \\
1.90 \\
1.90 \\
1.80 \\
1.80 \\
1.80 \\
4.20 \\
3.80 \\
4.20 \\
2.90 \\
2.80 \\
2.70 \\
2.50 \\
2.20 \\
2.20 \\
2.20 \\
2.60\end{array}$ \\
\hline
\end{tabular}

$a$ Gage broken; no record.

BROAD RIVER (OF THE CAROLINAS) AT DELLINGER, SOUTH CAROLINA.

The station at Gaffney, South Carolina, was abandoned on account of its poor section, and the station at Dellinger was established August 30,1900 , by $\mathrm{N}$. C. Curtis, in connection with the hydrographic investigations of the southern Appalachian region. The gage is a 4-inch by 4-inch timber, 13 feet long, spiked to a tree on the left bank of the river at Ellis's ferry, Dellinger, 1 mile below the North Carolina-South Carolina State line and 10 miles south of Shelby, North Carolina. The gage is graduated to feet and tenths and reads direct. The initial point of sounding is a stake in the center of the roadway, used for securing ferryboats to the bank. The channel is straight, the current rather rapid, and the bed of the stream sandy and slightly shifting. The right bank is about 10 feet high, and is not subject to overflow; the left bank rises to a considerable height. It has been observed that the surface of the water in the river is about 4 inches higher in the evening than in the morning. This may probably be accounted for by the fact that there are two cotton mills on Second Broad River which close their gates at night, in order to allow the ponds to fill, and cut off nearly all of the discharge of Second Broad River during low water. The observer is J. S. Gramling, ferryman. During 1900 N. C. Curtis made one measurement at this station, as follows:

August 30: Gage height, 0.8 foot; discharge, 1,430 second-feet. 
Daily gage height, in feet, of Broad River (of the Carolinas) at Dellinger, South Carolina, for 1900.

\begin{tabular}{|c|c|c|c|c|c|c|c|c|c|}
\hline Day. & Sept. & Oct. & Nov. & Dec. & Day. & Sept. & Oct. & Nov. & Dec. \\
\hline $\begin{array}{c}2 \\
3 \\
4 \\
5 \\
6 \\
6 \\
7\end{array}$ & $\begin{array}{r}0.60 \\
.70 \\
.70 \\
.60 \\
.60 \\
.60 \\
.50 \\
.30 \\
.50 \\
.50 \\
.50 \\
.40 \\
.40 \\
1.20 \\
.90\end{array}$ & $\begin{array}{r}0.55 \\
.60 \\
.50 \\
.50 \\
.50 \\
1.20 \\
.60 \\
.70 \\
1.00 \\
.80 \\
.60 \\
.60 \\
.50 \\
.30 \\
.75 \\
.30\end{array}$ & $\begin{array}{r}0.80 \\
.70 \\
.70 \\
.90 \\
.90 \\
.70 \\
.60 \\
.60 \\
.60 \\
.60 \\
.50 \\
.70 \\
.70 \\
.70 \\
.70 \\
.70\end{array}$ & $\begin{array}{l}1.35 \\
1.20 \\
1.30 \\
2.50 \\
3.15 \\
2.00 \\
1.70 \\
1.55 \\
1.20 \\
1.30 \\
1.20 \\
1.15 \\
1.15 \\
1.15 \\
1.15 \\
.80\end{array}$ & $\begin{array}{l}17 \\
18 \\
19 \\
20 \\
21\end{array}$ & $\begin{array}{c}1.50 \\
1.00 \\
.70 \\
.70 \\
.60 \\
.60 \\
.70 \\
.70 \\
.50 \\
.50 \\
.50 \\
.50 \\
\cdots \cdots \\
\cdots . .\end{array}$ & $\begin{array}{r}0.30 \\
.30 \\
.30 \\
.30 \\
.20 \\
.40 \\
1.00 \\
5.50 \\
2.50 \\
2.25 \\
1.28 \\
1.00 \\
.90 \\
.90 \\
.80\end{array}$ & $\begin{array}{r}0.70 \\
.50 \\
.70 \\
.70 \\
.70 \\
.70 \\
.70 \\
.70 \\
.90 \\
6.15 \\
2.80 \\
1.90 \\
1.60 \\
1.50\end{array}$ & $\begin{array}{r}1.00 \\
.90 \\
.90 \\
.95 \\
5.00 \\
3.25 \\
2.30 \\
2.50 \\
2.00 \\
1.90 \\
1.70 \\
1.60 \\
1.60 \\
1.75 \\
2.50\end{array}$ \\
\hline
\end{tabular}

BROAD RIVER (OF THE CAROLINAS) NEAR ALSTON, SOUTH CAROLINA.

This station is described in Water-Supply Paper No. 36, page 125. The river is straight for a long distance above and below the station, but the current is at an angle with the bridge. The current velocity is ample and is very uniform throughout the section. The observer is G. M. Heron, a farmer living near the station. The maximum flood at this station was on April 22, 1900, when the gage height was 23.80 feet and the probable discharge about 92,000 second-feet. The minimum flow was reached October 3,1899 , the discharge being 1,485 second-feet. The maximum discharge is, therefore, about 62 times the minimum flow. During 1900 the following discharge measurements were made by E. W. Myers:

February 26: Gage height, 5.40 feet; discharge, 8,913 second-feet. April 18: Gage height, 6.28 feet; discharge not measured.

April 20: Gage height, 13.60 feet; discharge, 44,456 second-feet.

May 22: Gage height, 3.40 feet; discharge, 4,406 second-feet.

July 5: Gage height, 4.25 feet; discharge, 5,962 second-feet.

August 17: Gage height, 2.80 feet; discharge, 2,840 second-feet. 
SOUTH CAROLINA.

Daily gage height, in feet, of Broad River (of the Carolinas) near Alston, South Carolina, for 1900.

\begin{tabular}{|c|c|c|c|c|c|c|c|c|c|c|c|c|}
\hline Day. & Jan. & Feb. & Mar. & Apr. & May. & June. & July. & Aug. & Sept. & Oct. & Nov. & Dec. \\
\hline $\begin{array}{l}26 \\
27 \\
28 \\
29 \\
30\end{array}$ & $\begin{array}{l}3.30 \\
3.45 \\
3.60 \\
3.80 \\
6.30 \\
7.50 \\
5.00 \\
3.80 \\
3.20 \\
2.78 \\
2.38 \\
2.36 \\
3.09 \\
3.87 \\
3.52 \\
3.38 \\
3.73 \\
3.58 \\
3.38 \\
3.29 \\
3.10 \\
2.90 \\
2.84 \\
3.10\end{array}$ & $\begin{array}{c}2.99 \\
2.80 \\
2.72 \\
2.74 \\
3.33 \\
3.52 \\
3.90 \\
3.45 \\
3.50 \\
3.58 \\
8.48 \\
9.84 \\
14.48 \\
19.95 \\
16.90 \\
11.11 \\
7.47 \\
5.57 \\
4.92 \\
4.51 \\
4.20 \\
9.25 \\
9.50 \\
6.64 \\
7.50 \\
5.50 \\
5.00 \\
4.50\end{array}$ & $\begin{array}{r}8.20 \\
14.20 \\
12.47 \\
8.20 \\
6.10 \\
5.52 \\
5.04 \\
5.16 \\
8.98 \\
8.30 \\
6.63 \\
5.43 \\
5.07 \\
4.66 \\
4.40 \\
11.68 \\
1.80 \\
8.87 \\
6.10 \\
5.30 \\
6.83 \\
5.84 \\
5.39 \\
5.08 \\
. .20 \\
10.80 \\
8.40 \\
6.54 \\
5.60 \\
5.11 \\
4.78\end{array}$ & $\begin{array}{r}4.64 \\
4.41 \\
4.17 \\
4.24 \\
4.58 \\
4.54 \\
4.08 \\
4.05 \\
4.00 \\
3.90 \\
3.88 \\
4.50 \\
4.70 \\
4.41 \\
4.40 \\
3.90 \\
3.70 \\
6.40 \\
17.20 \\
14.60 \\
15.50 \\
23.40 \\
18.10 \\
11.80 \\
10.00 \\
7.40 \\
7.30 \\
6.10 \\
5.65 \\
5.50\end{array}$ & $\begin{array}{l}5.00 \\
4.80 \\
4.60 \\
4.40 \\
4.25 \\
4.15 \\
4.10 \\
3.90 \\
3.90 \\
3.70 \\
3.60 \\
3.60 \\
3.65 \\
3.64 \\
3.64 \\
3.64 \\
3.50 \\
3.40 \\
4.80 \\
4.20 \\
3.60 \\
3.47 \\
3.42 \\
3.25 \\
6.50 \\
6.20 \\
5.55 \\
4.40 \\
3.85 \\
3.70 \\
3.55\end{array}$ & \begin{tabular}{|r}
3.45 \\
3.30 \\
3.48 \\
4.05 \\
4.45 \\
3.90 \\
3.70 \\
5.05 \\
4.45 \\
4.45 \\
4.20 \\
3.85 \\
3.60 \\
4.05 \\
4.32 \\
4.20 \\
10.00 \\
12.33 \\
8.60 \\
6.00 \\
5.00 \\
4.50 \\
10.55 \\
13.98 \\
10.00 \\
8.00 \\
6.85 \\
6.35 \\
5.95 \\
6.15
\end{tabular} & $\begin{array}{l}5.54 \\
4.90 \\
5.45 \\
5.45 \\
4.25 \\
.90 \\
3.90 \\
3.65 \\
4.76 \\
3.74 \\
3.40 \\
3.30 \\
3.20 \\
4.80 \\
4.40 \\
3.70 \\
3.50 \\
3.40 \\
3.25 \\
3.10 \\
3.10 \\
2.98 \\
3.40 \\
3.10 \\
3.42 \\
3.25 \\
4.32 \\
4.32 \\
4.35 \\
4.45 \\
4.95\end{array}$ & $\begin{array}{l}4.00 \\
3.85 \\
3.40 \\
3.30 \\
3.20 \\
3.10 \\
2.80 \\
3.03 \\
3.05 \\
2.90 \\
2.82 \\
2.80 \\
2.85 \\
2.60 \\
2.95 \\
2.90 \\
2.80 \\
2.85 \\
2.85 \\
2.75 \\
2.35 \\
2.60 \\
2.55 \\
3.50 \\
3.35 \\
2.80 \\
3.10 \\
2.60 \\
2.75 \\
2.90 \\
3.10\end{array}$ & $\begin{array}{l}3.15 \\
3.20 \\
2.80 \\
2.50 \\
2.70 \\
2.60 \\
2.50 \\
2.50 \\
2.48 \\
2.30 \\
2.05 \\
2.30 \\
2.35 \\
2.38 \\
2.65 \\
5.30 \\
6.12 \\
4.10 \\
3.20 \\
3.05 \\
2.85 \\
2.65 \\
2.58 \\
2.40 \\
2.50 \\
2.80 \\
2.65 \\
2.50 \\
2.45 \\
2.45\end{array}$ & $\begin{array}{l}2.55 \\
2.30 \\
2.60 \\
2.60 \\
2.05 \\
3.05 \\
3.35 \\
3.30 \\
3.10 \\
2.70 \\
3.25 \\
3.15 \\
2.90 \\
2.85 \\
3.10 \\
3.00 \\
2.50 \\
2.85 \\
2.70 \\
2.70 \\
2.60 \\
2.65 \\
2.60 \\
2.35 \\
6.95 \\
8.40 \\
5.85 \\
3.90 \\
3.55 \\
3.30 \\
3.00 \\
3.15\end{array}$ & $\begin{array}{c}2.95 \\
2.88 \\
3.70 \\
7.51 \\
7.20 \\
5.00 \\
3.75 \\
3.50 \\
3.15 \\
3.05 \\
2.90 \\
2.80 \\
2.70 \\
3.00 \\
2.90 \\
2.85 \\
2.90 \\
2.95 \\
2.95 \\
2.75 \\
3.55 \\
3.35 \\
3.20 \\
3.15 \\
3.05 \\
3.90 \\
10.13 \\
6.35 \\
4.65 \\
3.85\end{array}$ & $\begin{array}{l}3.60 \\
3.45 \\
3.25 \\
7.83 \\
9.20 \\
6.50 \\
4.95 \\
4.25 \\
3.90 \\
3.60 \\
3.55 \\
3.45 \\
3.35 \\
3.60 \\
3.70 \\
3.30 \\
3.05 \\
3.10 \\
3.20 \\
3.30 \\
7.20 \\
8.55 \\
7.20 \\
5.15 \\
4.80 \\
4.45 \\
4.20 \\
3.80 \\
3.70 \\
3.95 \\
6.30\end{array}$ \\
\hline
\end{tabular}

SALUDA RIVER AT WATERLOO, SOUTH CAROLINA.

This station is described in Water-Supply Paper No. 36, page 126. Records of flow during 1899 will be found in the Twenty-first Annual Report, Part IV, page 129. During 1900 the following measurements were made by $\mathrm{E}$. W. Myers:

February 23: Gage height, 7.33 feet; discharge, 3,347 second-feet.

April 19: Gage height, 9.91 feet; discharge, 5,415 second-feet.

May 22: Gage height, 3.35 feet; discharge, 757 second-feet.

July 5: Gage height, 5.10 feet; discharge, 1,486 second-feet.

August 17: Gage height, 4.10 feet; discharge 917 second-feet.

November 10: Gage height, 4.42 feet; discharge, 854 second-feet. 
Daily gage height, in feet, of Saluda River at Waterloo, South Carolina, for 1900.

\begin{tabular}{|c|c|c|c|c|c|c|c|c|c|c|c|c|}
\hline Day. & Jan. & Feb. & Mar. & Apr. & May. & June. & July. & Aug. & Sept. & Oct. & Nov. & Dec. \\
\hline $\begin{array}{r}1 \\
2 \\
3\end{array}$ & $\begin{array}{l}3.60 \\
4.00 \\
4.55 \\
4.50 \\
4.30 \\
4.05 \\
3.80 \\
3.40 \\
4.00 \\
4.65 \\
4.85 \\
9.55 \\
7.80 \\
5.65 \\
5.05 \\
5.30 \\
5.05 \\
4.90 \\
5.15 \\
5.20 \\
5.45 \\
4.00 \\
5.20 \\
4.90 \\
5.00 \\
4.95 \\
5.00 \\
3.95 \\
4.15 \\
4.05 \\
4.00\end{array}$ & $\begin{array}{r}4.00 \\
4.10 \\
4.80 \\
3.95 \\
4.60 \\
5.25 \\
\mathbf{5 . 3 0} \\
\mathbf{5 . 2 0} \\
4.25 \\
6.75 \\
7.80 \\
10.30 \\
16.40 \\
20.00 \\
17.00 \\
8.40 \\
7.00 \\
\mathbf{5 . 4 5} \\
\mathbf{5 . 9 0} \\
\mathbf{5 . 5 0} \\
\mathbf{6 . 1 0} \\
\mathbf{8 . 5 0} \\
7.70 \\
\mathbf{5 . 5 5} \\
\mathbf{6 . 9 0} \\
\mathbf{5 . 8 0} \\
\mathbf{5} .70 \\
\mathbf{5 . 2 0}\end{array}$ & $\begin{array}{r}10.20 \\
11.95 \\
10.70 \\
7.20 \\
6.35 \\
6.00 \\
5.65 \\
8.80 \\
10.05 \\
8.30 \\
7.40 \\
6.05 \\
5.85 \\
5.70 \\
5.80 \\
11.05 \\
10.70 \\
8.00 \\
6.90 \\
8.10 \\
7.40 \\
6.65 \\
6.10 \\
6.90 \\
9.15 \\
8.15 \\
7.80 \\
6.85 \\
6.30 \\
6.10 \\
6.05\end{array}$ & $\begin{array}{r}6.00 \\
5.55 \\
5.05 \\
5.10 \\
5.35 \\
5.15 \\
5.35 \\
5.45 \\
4.35 \\
4.85 \\
5.50 \\
5.90 \\
5.40 \\
5.70 \\
5.05 \\
5.00 \\
4.90 \\
8.65 \\
9.55 \\
8.80 \\
13.40 \\
16.80 \\
14.40 \\
12.55 \\
9.30 \\
7.70 \\
7.40 \\
7.00 \\
6.55 \\
6.30\end{array}$ & $\begin{array}{l}6.40 \\
6.10 \\
5.70 \\
5.70 \\
5.70 \\
5.95 \\
5.00 \\
4.90 \\
4.85 \\
4.95 \\
4.65 \\
5.40 \\
5.00 \\
5.00 \\
4.65 \\
4.83 \\
4.45 \\
5.10 \\
5.75 \\
5.35 \\
4.55 \\
5.20 \\
4.40 \\
8.50 \\
7.35 \\
6.45 \\
6.10 \\
4.50 \\
5.30 \\
4.60 \\
5.30\end{array}$ & $\begin{array}{r}4.50 \\
4.20 \\
4.40 \\
5.45 \\
4.90 \\
5.10 \\
8.10 \\
10.90 \\
10.00 \\
6.90 \\
6.00 \\
5.80 \\
5.25 \\
6.20 \\
7.00 \\
6.55 \\
10.25 \\
8.70 \\
7.00 \\
6.50 \\
5.95 \\
6.10 \\
8.55 \\
11.80 \\
10.70 \\
10.80 \\
8.25 \\
8.25 \\
7.35 \\
8.30\end{array}$ & $\begin{array}{l}7.40 \\
5.85 \\
6.45 \\
6.25 \\
5.90 \\
5.65 \\
5.20 \\
5.20 \\
5.40 \\
4.85 \\
4.70 \\
4.55 \\
4.75 \\
5.80 \\
6.10 \\
4.90 \\
4.60 \\
4.60 \\
4.50 \\
4.45 \\
5.30 \\
4.20 \\
5.05 \\
5.30 \\
4.35 \\
5.30 \\
4.40 \\
5.40 \\
4.95 \\
4.70 \\
5.30\end{array}$ & $\begin{array}{l}4.35 \\
4.50 \\
4.95 \\
4.70 \\
4.65 \\
3.65 \\
4.05 \\
4.15 \\
5.15 \\
3.95 \\
5.00 \\
3.80 \\
3.65 \\
3.90 \\
4.00 \\
4.55 \\
4.50 \\
4.10 \\
4.00 \\
3.30 \\
3.85 \\
4.10 \\
4.05 \\
4.15 \\
5.20 \\
4.00 \\
3.75 \\
4.40 \\
4.00 \\
4.60 \\
4.95\end{array}$ & $\begin{array}{l}4.70 \\
4.90 \\
4.00 \\
4.00 \\
4.10 \\
4.05 \\
4.00 \\
4.65 \\
3.70 \\
3.00 \\
4.28 \\
4.00 \\
3.95 \\
4.10 \\
4.75 \\
8.75 \\
6.10 \\
4.25 \\
4.20 \\
5.20 \\
4.00 \\
4.95 \\
4.15 \\
3.55 \\
4.10 \\
4.10 \\
4.60 \\
4.05 \\
4.80 \\
3.80\end{array}$ & $\begin{array}{l}3.10 \\
3.90 \\
4.10 \\
4.80 \\
4.40 \\
4.60 \\
3.80 \\
3.10 \\
4.10 \\
5.00 \\
4.25 \\
4.10 \\
4.90 \\
3.95 \\
3.20 \\
4.60 \\
4.40 \\
4.65 \\
4.20 \\
4.55 \\
5.80 \\
3.05 \\
4.20 \\
8.30 \\
8.10 \\
6.70 \\
5.35 \\
4.70 \\
3.90 \\
5.20 \\
5.25\end{array}$ & $\begin{array}{r}4.35 \\
4.40 \\
6.60 \\
7.75 \\
4.70 \\
5.60 \\
5.40 \\
4.50 \\
4.55 \\
5.15 \\
4.20 \\
3.45 \\
5.10 \\
5.15 \\
5.05 \\
4.40 \\
4.70 \\
4.10 \\
3.50 \\
4.60 \\
4.45 \\
4.50 \\
5.25 \\
5.10 \\
4.50 \\
10.20 \\
9.90 \\
8.40 \\
5.20 \\
5.55\end{array}$ & $\begin{array}{l}5.45 \\
4.90 \\
4.60 \\
7.85 \\
7.90 \\
5.95 \\
5.80 \\
5.55 \\
5.05 \\
4.30 \\
5.40 \\
5.35 \\
5.45 \\
4.90 \\
5.45 \\
4.20 \\
4.25 \\
5.25 \\
4.50 \\
5.20 \\
5.20 \\
5.65 \\
5.15 \\
5.00 \\
5.45 \\
4.85 \\
4.60 \\
4.45 \\
5.35 \\
5.55 \\
5.70\end{array}$ \\
\hline
\end{tabular}

TALLULAH RIVER AT TALLULAH FALLS, GEORGIA.'

This station was established August 29, 1900, and records of gage heights were obtained until October 19, 1900, when the observer left Tallulah Falls, and no readings have been made since that time. Measurements are made from the wagon bridge across the river about a half mile above the head of the falls. The bridge is a single iron span about 100 feet long. The gage is a vertical rod 10 feet long, graduated to feet and tenths, nailed to a 2 -inch by 4 -inch pine timber, and the whole spiked to a tree on the left bank of the river about 50 feet above the bridge. The observer is T. A. Robinson, proprietor of the Robinson Hotel. During 1900 the following measurements were made by Max Hall and J. C. Conn:

August 29: Gage height, 1 foot; discharge, 252 second-feet.

December 21: Gage height, 2 feet; discharge, 963 second-feet.

Daily gage height, in feet, of Tallulah River at Tallulah Falls, Georgia, for 1900.

\begin{tabular}{|c|c|c|c|c|c|c|c|c|c|c|c|}
\hline Day. & Aug. & Sept. & Oct. & Day. & Aug. & Sept. & Oct. & Day. & Aug. & Sept. & Oct. \\
\hline $\begin{array}{r}1 \\
1 \\
4 \\
4 \\
6\end{array}$ & 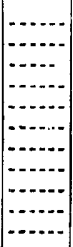 & $\begin{array}{l}1.50 \\
1.40 \\
1.10 \\
1.00 \\
1.00 \\
1.00 \\
1.00 \\
1.00 \\
.90 \\
.90 \\
.90\end{array}$ & $\begin{array}{l}1.03 \\
1.03 \\
1.02 \\
1.01 \\
1.01 \\
1.03 \\
1.03 \\
1.02 \\
1.02 \\
1.01 \\
1.01\end{array}$ & $\begin{array}{l}12 \\
13 \\
14 \\
15 \\
16 \\
17 \\
18 \\
19 \\
20\end{array}$ & 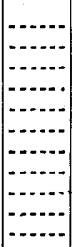 & \begin{tabular}{|}
.85 \\
.80 \\
1.20 \\
1.95 \\
2.90 \\
1.95 \\
1.70 \\
1.40 \\
1.35 \\
1.30 \\
5.40
\end{tabular} & \begin{tabular}{l}
1.01 \\
1.01 \\
1.00 \\
1.00 \\
1.00 \\
1.00 \\
1.00 \\
1.00 \\
\hdashline... \\
\hdashline...
\end{tabular} & $\begin{array}{l}23 \\
24 \\
25 \\
26 \\
27 \\
28 \\
29 \\
30 \\
31\end{array}$ & $\begin{array}{r}1.00 \\
1.65\end{array}$ & $\begin{array}{l}1.25 \\
1.20 \\
1.20 \\
1.19 \\
1.17 \\
1.10 \\
1.09 \\
1.04 \\
\cdots \cdots . .\end{array}$ & 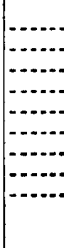 \\
\hline
\end{tabular}


TUGALOO RIVER NEAR MADISON, SOUTH CAROLINA.

This station, established July 19, 1898, at Cook's ferry, about a half mile from Madison, South Carolina, 1 mile below the Southern Railway bridge over Tugaloo River and 2 miles above the mouth of Chauga Creek, is described in Water-Supply Paper No., 36, page 127. Results of measurements are given in the Twentieth Annual Report, Part IV, page 162, and in the Twenty-first Annual Report, Part IV, page 131. During 1900 the following measurements were made by Max Hall and others:

February 21: Gage height, 4.25 feet; discharge, 2,243 second-feet.

August 30: Gage height, 1.71 feet; discharge, 872 second-feet.

December 25: Gage height, 3.60 feet; discharge, 1,717 second-feet.

December 27: Gage height, 2.80 feet; discharge, 1,414 second-feet.

Daily gage height, in feet, of Tugaloo River near Madison, South Carolina, for 1900.

\begin{tabular}{|c|c|c|c|c|c|c|c|c|c|c|c|c|}
\hline Day. & Jan. & Feb. & Mar. & Apr. & May. & June. & July. & Aug. & Sept. & Oct. & Nov. & Dec. \\
\hline $\begin{array}{l}1 \\
2 \\
3\end{array}$ & $\begin{array}{l}1.4 \\
1.3 \\
1.3 \\
1.3 \\
1.2 \\
1.2 \\
1.2 \\
1.2 \\
1.2 \\
1.4 \\
1.6 \\
5.5 \\
3.3 \\
2.5 \\
2.1 \\
2.0 \\
1.9 \\
1.8 \\
4.5 \\
3.9 \\
3.1 \\
2.9 \\
2.4 \\
2.4 \\
2.2 \\
2.1 \\
1.9 \\
1.9 \\
1.8 \\
1.8\end{array}$ & $\begin{array}{r}1.6 \\
1.6 \\
1.8 \\
1.7 \\
3.5 \\
2.3 \\
2.1 \\
2.2 \\
3.0 \\
3.5 \\
4.6 \\
7.0 \\
19.9 \\
9.0 \\
6.2 \\
5.2 \\
4.5 \\
4.0 \\
3.8 \\
3.5 \\
3.5 \\
5.0 \\
4.0 \\
3.8 \\
4.0 \\
3.5 \\
3.3 \\
3.1\end{array}$ & $\begin{array}{l}9.4 \\
5.5 \\
3.9 \\
3.9 \\
3.7 \\
3.5 \\
3.8 \\
4.3 \\
6.6 \\
5.1 \\
4.5 \\
4.2 \\
3.9 \\
3.7 \\
3.6 \\
5.1 \\
4.0 \\
3.6 \\
3.7 \\
6.2 \\
5.0 \\
4.4 \\
4.2 \\
4.1 \\
4.2 \\
5.8 \\
4.8 \\
4.3 \\
4.1 \\
3.9 \\
3.7\end{array}$ & $\begin{array}{r}3.5 \\
3.4 \\
3.4 \\
3.6 \\
3.7 \\
3.4 \\
3.3 \\
3.2 \\
3.1 \\
3.1 \\
3.3 \\
4.1 \\
3.8 \\
3.4 \\
3.2 \\
3.0 \\
5.9 \\
5.1 \\
7.6 \\
7.5 \\
13.4 \\
8.3 \\
6.3 \\
6.2 \\
5.3 \\
4.9 \\
4.6 \\
4.9 \\
4.7 \\
4.4\end{array}$ & $\begin{array}{l}4.2 \\
4.1 \\
4.3 \\
4.0 \\
3.8 \\
3.7 \\
3.6 \\
3.4 \\
3.4 \\
3.3 \\
3.2 \\
3.1 \\
3.1 \\
3.0 \\
2.9 \\
2.9 \\
2.8 \\
2.8 \\
3.3 \\
2.8 \\
2.7 \\
2.6 \\
2.5 \\
3.3 \\
2.9 \\
2.9 \\
2.7 \\
2.5 \\
2.5 \\
2.4 \\
2.3\end{array}$ & $\begin{array}{r}2.3 \\
2.6 \\
2.8 \\
2.7 \\
2.9 \\
2.9 \\
5.5 \\
6.7 \\
4.5 \\
3.6 \\
3.3 \\
3.0 \\
3.3 \\
3.3 \\
3.1 \\
3.0 \\
6.9 \\
5.3 \\
4.5 \\
3.9 \\
3.5 \\
4.2 \\
5.8 \\
13.0 \\
9.4 \\
11.4 \\
6.5 \\
6.9 \\
6.4 \\
5.7\end{array}$ & $\begin{array}{l}5.1 \\
5.6 \\
5.1 \\
4.6 \\
4.2 \\
3.9 \\
3.8 \\
3.6 \\
3.8 \\
3.6 \\
3.7 \\
3.6 \\
3.9 \\
3.9 \\
3.7 \\
3.6 \\
3.2 \\
3.1 \\
3.0 \\
2.9 \\
2.8 \\
2.8 \\
3.1 \\
2.9 \\
2.7 \\
3.6 \\
3.2 \\
3.8 \\
3.1 \\
4.2 \\
3.3\end{array}$ & $\begin{array}{l}3.1 \\
2.8 \\
2.7 \\
2.5 \\
2.5 \\
2.4 \\
2.3 \\
2.3 \\
2.2 \\
2.1 \\
2.1 \\
2.1 \\
2.2 \\
2.0 \\
2.3 \\
2.1 \\
2.3 \\
2.1 \\
2.0 \\
1.9 \\
1.8 \\
2.8 \\
2.1 \\
2.3 \\
2.1 \\
2.2 \\
1.9 \\
1.8 \\
1.7 \\
2.7 \\
2.8\end{array}$ & $\begin{array}{l}2.5 \\
2.8 \\
2.1 \\
1.9 \\
1.8 \\
1.7 \\
1.6 \\
1.6 \\
1.5 \\
1.5 \\
1.5 \\
1.4 \\
1.4 \\
1.6 \\
8.1 \\
7.3 \\
4.0 \\
2.9 \\
2.6 \\
2.3 \\
2.2 \\
2.1 \\
2.0 \\
2.0 \\
2.9 \\
1.8 \\
2.1 \\
1.9 \\
1.8 \\
1.7\end{array}$ & $\begin{array}{l}1.7 \\
1.6 \\
1.7 \\
1.7 \\
1.9 \\
3.2 \\
1.8 \\
1.8 \\
1.5 \\
1.8 \\
1.7 \\
1.6 \\
2.6 \\
1.8 \\
1.6 \\
1.6 \\
1.5 \\
1.5 \\
1.4 \\
1.4 \\
1.4 \\
7.6 \\
7.4 \\
4.9 \\
3.9 \\
2.9 \\
2.6 \\
2.5 \\
2.3 \\
2.2\end{array}$ & $\begin{array}{l}2.1 \\
2.1 \\
2.2 \\
2.9 \\
2.3 \\
2.1 \\
2.0 \\
2.0 \\
1.9 \\
1.9 \\
1.8 \\
1.8 \\
1.7 \\
1.7 \\
1.7 \\
1.7 \\
1.9 \\
2.0 \\
2.0 \\
2.0 \\
1.9 \\
1.9 \\
2.2 \\
9.4 \\
5.3 \\
4.1 \\
3.0 \\
3.4\end{array}$ & $\begin{array}{r}2.5 \\
2.5 \\
2.3 \\
5.6 \\
4.8 \\
3.4 \\
3.1 \\
3.0 \\
2.9 \\
2.6 \\
2.5 \\
2.4 \\
2.3 \\
23 \\
2.2 \\
2.2 \\
2.1 \\
2.1 \\
2.0 \\
2.3 \\
4.2 \\
3.3 \\
3.0 \\
4.2 \\
3.6 \\
3.1 \\
2.8 \\
2.7 \\
2.6 \\
2.6 \\
4.0\end{array}$ \\
\hline
\end{tabular}

SAVANNAH RIVER NEAR CALHOUN FALLS, SOUTH CAROLINA.

This station was established August 4, 1896, on the Seaboard Air Line bridge across Savannah River, above the mouth of Beaverdam Creek, below Rocky River, and about 3 miles west of the town of Calhoun Falls, South Carolina. It is described in Water-Supply Paper No. 36, page 129. More than four-fifths of the drainage area of this river in the Blue Ridge Mountains in North Carolina, South Carolina, and Georgia is covered with the original oak forest. Records of flow during 1899 will be found in the Twenty-first Annual Report,

IRR $48-01-4$ 
Part IV, page 134. During 1900 the following measurement was made by Max Hall:

March 1: Gage height, 5.47 feet; discharge, 13,803 second-feet.

Daily gage height, in feet, of Savannah River near Calhoun Falls, South Carolina, for 1900 .

\begin{tabular}{|c|c|c|c|c|c|c|c|c|c|c|c|c|}
\hline Day. & Jan. & Feb. & Mar. & Apr. & May. & June. & July. & Aug. & Sept. & Oct. & Nov. & Dec. \\
\hline $\begin{array}{l}24 \\
25 \\
26 \\
27 \\
28 \\
29 \\
31\end{array}$ & $\begin{array}{l}3.3 \\
3.2 \\
3.2 \\
3.1 \\
3.0 \\
3.0 \\
2.9 \\
2.9 \\
2.9 \\
3.0 \\
3.2 \\
4.0 \\
3.9 \\
3.7 \\
3.6 \\
3.5 \\
3.3 \\
3.3 \\
3.4 \\
3.9 \\
3.8 \\
3.6 \\
3.5 \\
3.4 \\
3.2 \\
3.2 \\
3.1 \\
3.0 \\
3.0 \\
3.0 \\
2.9\end{array}$ & $\begin{array}{r}2.9 \\
2.8 \\
2.8 \\
2.7 \\
2.8 \\
2.8 \\
2.9 \\
2.9 \\
3.0 \\
3.2 \\
5.2 \\
9.3 \\
15.5 \\
19.4 \\
8.0 \\
5.5 \\
4.9 \\
4.7 \\
4.4 \\
4.3 \\
4.2 \\
5.4 \\
4.7 \\
4.4 \\
4.2 \\
4.0 \\
3.9 \\
3.9\end{array}$ & $\begin{array}{l}5.3 \\
6.5 \\
4.6 \\
4.2 \\
3.9 \\
3.8 \\
3.6 \\
4.0 \\
4.9 \\
4.3 \\
3.9 \\
3.8 \\
3.6 \\
3.4 \\
3.3 \\
4.6 \\
4.5 \\
4.0 \\
3.8 \\
4.2 \\
4.0 \\
3.9 \\
3.8 \\
4.0 \\
5.6 \\
5.7 \\
5.0 \\
4.8 \\
4.2 \\
3.9 \\
3.7\end{array}$ & $\begin{array}{r}3.6 \\
3.5 \\
3.5 \\
3.7 \\
3.6 \\
3.4 \\
3.3 \\
3.4 \\
3.4 \\
3.3 \\
3.6 \\
4.0 \\
3.8 \\
3.6 \\
3.6 \\
3.5 \\
3.5 \\
3.9 \\
5.0 \\
5.1 \\
8.0 \\
10.4 \\
5.5 \\
6.9 \\
6.0 \\
4.9 \\
4.2 \\
4.0 \\
4.2 \\
4.0\end{array}$ & $\begin{array}{l}4.0 \\
3.9 \\
4.2 \\
4.0 \\
3.9 \\
3.7 \\
3.6 \\
3.4 \\
3.3 \\
3.1 \\
3.1 \\
3.0 \\
3.0 \\
3.0 \\
.99 \\
.99 \\
2.9 \\
3.8 \\
3.0 \\
3.0 \\
2.9 \\
2.9 \\
3.0 \\
4.9 \\
4.2 \\
3.2 \\
3.0 \\
3.0 \\
2.9 \\
2.9 \\
2.8\end{array}$ & $\begin{array}{r}2.8 \\
2.7 \\
3.1 \\
2.9 \\
3.5 \\
3.4 \\
.99 \\
11.0 \\
5.0 \\
3.5 \\
3.0 \\
3.0 \\
3.1 \\
3.0 \\
3.0 \\
3.3 \\
5.6 \\
6.1 \\
4.9 \\
4.0 \\
3.7 \\
3.6 \\
4.0 \\
12.7 \\
12.0 \\
7.8 \\
5.0 \\
4.5 \\
3.9 \\
3.8\end{array}$ & 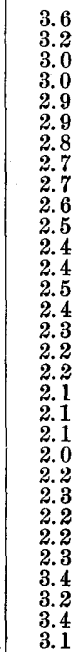 & 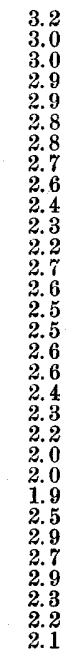 & $\begin{array}{l}3.2 \\
3.7 \\
3.3 \\
3.0 \\
3.0 \\
2.9 \\
2.8 \\
2.6 \\
2.5 \\
2.3 \\
2.2 \\
2.1 \\
2.0 \\
2.0 \\
4.7 \\
6.9 \\
5.0 \\
3.2 \\
3.0 \\
2.9 \\
2.9 \\
2.7 \\
2.7 \\
2.6 \\
2.4 \\
2.4 \\
2.2 \\
2.0 \\
2.0 \\
2.1\end{array}$ & $\begin{array}{l}2.1 \\
2.0 \\
2.0 \\
2.1 \\
2.1 \\
3.0 \\
2.7 \\
2.6 \\
2.5 \\
2.4 \\
2.4 \\
2.6 \\
3.9 \\
3.0 \\
2.9 \\
2.8 \\
2.6 \\
2.5 \\
2.5 \\
2.4 \\
2.4 \\
2.4 \\
2.5 \\
5.0 \\
4.0 \\
3.9 \\
3.7 \\
3.5 \\
3.3 \\
3.1 \\
2.9\end{array}$ & $\begin{array}{l}2.9 \\
3.0 \\
3.9 \\
4.3 \\
4.0 \\
3.8 \\
3.7 \\
3.4 \\
3.3 \\
3.2 \\
3.2 \\
3.0 \\
2.9 \\
2.7 \\
2.7 \\
2.6 \\
2.6 \\
2.6 \\
2.6 \\
3.0 \\
2.9 \\
2.8 \\
2.8 \\
2.6 \\
2.6 \\
3.6 \\
3.4 \\
3.2 \\
3.1 \\
3.0\end{array}$ & $\begin{array}{l}3.0 \\
2.9 \\
2.8 \\
3.9 \\
3.8 \\
3.8 \\
3.7 \\
3.6 \\
3.4 \\
3.4 \\
3.3 \\
3.3 \\
3.4 \\
3.7 \\
3.6 \\
3.4 \\
3.4 \\
3.3 \\
3.3 \\
3.6 \\
3.7 \\
3.5 \\
3.4 \\
3.4 \\
3.3 \\
3.3 \\
3.3 \\
3.2 \\
3.2 \\
3.3 \\
3.3\end{array}$ \\
\hline
\end{tabular}

SAVANNAH RIVER AT AUGUSTA, GEORGIA.

Observations of river heights have been maintained at the highway bridge in the city of Augusta since 1875. The station is described in Water-Supply Paper No. 36, page 130. The gage heights as published are the average of four daily readings reduced to feet and hundredths. Discharge measurements are made at the North Augusta highway bridge. Records of flow during 1899 will be found in the Twenty-first Annual Report, Part IV, page 135. During 1900 one measurement was made by B. M. Hall, as follows:

August 28: Gage height, 7.30 feet; discharge, 5,968 second-feet. 
Daily gage height, in feet, of Savannah River at Augusta, Georgia, for 1900.

\begin{tabular}{|c|c|c|c|c|c|c|c|c|c|c|c|c|}
\hline & an. & eb. & Mar. & Apr. & Lay. & une. & uly. & lug. & Sept. & Oct. & Nov. & Dec \\
\hline $\begin{array}{l}1 \\
2 \\
3 \\
4 \\
5 \\
6 \\
7 \\
8 \\
9\end{array}$ & $\begin{array}{r}7.12 \\
6.94 \\
6.67 \\
6.42 \\
6.50 \\
6.67 \\
6.39 \\
6.65 \\
6.71 \\
6.71 \\
7.12 \\
10.40 \\
15.00 \\
12.79 \\
9.37 \\
8.65 \\
8.12 \\
7.67 \\
7.94 \\
8.94 \\
10.26 \\
10.44 \\
9.11 \\
8.44 \\
8.12 \\
7.96 \\
7.73 \\
7.19 \\
7.22 \\
7.20 \\
7.08\end{array}$ & $\begin{array}{r}6.87 \\
6.81 \\
6.44 \\
6.52 \\
8.33 \\
9.10 \\
8.89 \\
8.08 \\
8.12 \\
10.04 \\
20.58 \\
27.19 \\
29.60 \\
32.31 \\
30.08 \\
22.08 \\
16.29 \\
12.75 \\
11.39 \\
10.46 \\
10.35 \\
14.79 \\
15.44 \\
12.89 \\
12.96 \\
12.37 \\
10.98 \\
10.31\end{array}$ & $\begin{array}{l}13.87 \\
14.06 \\
11.44 \\
10.60 \\
10.37 \\
10.64 \\
17.35 \\
17.60 \\
14.35 \\
12.21 \\
10.96 \\
10.39 \\
10.08 \\
10.25 \\
17.27 \\
14.21 \\
11.42 \\
13.68 \\
15.25 \\
13.70 \\
11.85 \\
11.73 \\
14.10 \\
19.65 \\
18.37 \\
14.79 \\
12.67 \\
11.46 \\
10.69\end{array}$ & $\begin{array}{r}9 . \\
9 . \\
9 . \\
9 . \\
9 . \\
9 . \\
9 . \\
9 . \\
8 . \\
8 . \\
9 . \\
11 . \\
11 . \\
9 . \\
9 . \\
8 . \\
12 .\end{array}$ & $\begin{array}{l}9 . \\
9 . \\
9 . \\
9 \\
8 . \\
8 \\
8 . \\
8 . \\
8 . \\
8 . \\
8 . \\
7 .\end{array}$ & $\begin{array}{r}10 . \\
9 \\
9 \\
9 \\
9\end{array}$ & $\begin{array}{r}14.46 \\
12.90 \\
12.25 \\
11.66 \\
10.60 \\
9.62 \\
9.27 \\
8.96 \\
8.79 \\
8.39 \\
8.52 \\
8.22 \\
8.68 \\
8.94 \\
9.60 \\
9.37 \\
8.64 \\
8.37 \\
8.19 \\
8.04 \\
7.89 \\
7.39 \\
8.00 \\
8.20 \\
8.92 \\
8.32 \\
9.23 \\
11.12 \\
10.20 \\
11.88 \\
13.35\end{array}$ & $\begin{array}{l}8.30 \\
7.76 \\
7.73 \\
7.33 \\
7.27 \\
7.19 \\
7.13 \\
7.09 \\
7.06 \\
6.57 \\
6.62 \\
7.31 \\
7.17 \\
6.77 \\
7.67 \\
7.27 \\
6.78 \\
6.82 \\
6.62 \\
6.48 \\
6.50 \\
6.56 \\
6.77 \\
7.77 \\
7.12 \\
7.20 \\
6.69 \\
6.62 \\
7.08\end{array}$ & $\begin{array}{l}8.35 \\
7.70 \\
7.27 \\
7.12 \\
6.92 \\
6.35 \\
6.75 \\
6.50 \\
6.67 \\
6.46 \\
6.50 \\
6.19\end{array}$ & $\begin{array}{l}0 \\
0 \\
5 \\
5 \\
8 \\
4 \\
2 \\
6 \\
7 \\
5 \\
7 \\
5 \\
0 \\
2 \\
6\end{array}$ & $\begin{array}{r}7.20 \\
7.30 \\
7.70 \\
13.80 \\
12.00 \\
9.30 \\
8.00 \\
7.70 \\
7.50 \\
7.40 \\
6.90 \\
7.00 \\
7.10 \\
7.00 \\
7.00 \\
6.80 \\
6.80 \\
6.50 \\
6.80 \\
7.20 \\
7.50 \\
7.40 \\
7.30 \\
7.40 \\
7.00 \\
10.00 \\
14.90 \\
11.80 \\
9.10 \\
8.30\end{array}$ & $\begin{array}{r}8.8 \\
11.5 \\
9.8 \\
8.6 \\
7.9 \\
7.4 \\
8.1 \\
12.1 \\
12.7 \\
11.1 \\
9.3 \\
9.4 \\
9.2 \\
8.7 \\
8.4 \\
8.2 \\
8.4 \\
15.2\end{array}$ \\
\hline
\end{tabular}

BROAD RIVER (OF GEORGIA) NEAR CARLTON, GEORGIA.

This station, established May 27, 1897, is located on the bridge of the Seaboard Air Line 3 miles east of Carlton, Georgia, and 3 miles above the mouth of the South Fork. A description of the station is given in Water-Supply Paper No. 36, page 131. The gage was last verified on October 17, 1900. Records of flow for 1899 will be found in the Twenty-first Annual Report, Part IV, page 132. During 1900 the following measurements were made by Max Hall:

February 16: Gage height, 4.25 feet; discharge, 2,088 second-feet.

March 30: Gage height, 3.30 feet; discharge, 1,480 second-feet.

May 3: Gage height, 4.49 feet; discharge, 2,562 second-feet.

October 17: Gage height, 2.22 feet; discharge, 661 second-feet. 
Daily gage height, in feet, of Broad River (of Georgia) near Carlton, Georgia for 1900 .

\begin{tabular}{|c|c|c|c|c|c|c|c|c|c|c|c|c|}
\hline Day: & Jan. & Feb. & Mar. & Apr. & May. & June. & July. & Aug. & Sept. & Oct. & Nov. & De \\
\hline - & $\begin{array}{l}2.40 \\
2.40 \\
2.40 \\
2.35 \\
2.35 \\
2.30 \\
2.30 \\
2.30 \\
2.30 \\
2.40 \\
2.90 \\
5.85 \\
4.90 \\
3.30 \\
2.95 \\
2.75 \\
2.65 \\
3.15 \\
3.60 \\
3.75 \\
3.70 \\
2.85 \\
2.70 \\
2.60 \\
2.50 \\
2.45 \\
2.45 \\
2.40 \\
2.40 \\
2.35 \\
2.30\end{array}$ & $\begin{array}{r}2.30 \\
2.30 \\
2.30 \\
2.30 \\
3.30 \\
3.30 \\
2.95 \\
2.70 \\
2.65 \\
2.80 \\
4.00 \\
6.00 \\
10.50 \\
22.20 \\
16.90 \\
8.00 \\
4.30 \\
3.70 \\
3.30 \\
3.20 \\
3.10 \\
3.10 \\
3.80 \\
3.65 \\
3.20 \\
3.65 \\
3.60 \\
3.20 \\
3.00\end{array}$ & $\begin{array}{l}5.50 \\
4.90 \\
3.85 \\
3.30 \\
3.15 \\
3.00 \\
3.00 \\
6.50 \\
6.80 \\
5.10 \\
3.80 \\
3.30 \\
3.20 \\
3.10 \\
3.00 \\
4.20 \\
3.80 \\
3.30 \\
3.10 \\
4.60 \\
4.10 \\
3.70 \\
3.40 \\
3.60 \\
4.70 \\
6.50 \\
5.30 \\
4.00 \\
3.50 \\
3.30 \\
3.25\end{array}$ & $\begin{array}{r}3.10 \\
3.10 \\
3.00 \\
3.10 \\
3.00 \\
3.00 \\
2.90 \\
2.80 \\
2.80 \\
2.70 \\
3.50 \\
3.90 \\
3.90 \\
3.30 \\
3.10 \\
3.00 \\
2.90 \\
3.90 \\
7.50 \\
6.70 \\
8.00 \\
12.20 \\
5.80 \\
6.50 \\
7.30 \\
5.10 \\
3.90 \\
3.70 \\
3.50 \\
3.50\end{array}$ & $\begin{array}{l}3.40 \\
3.20 \\
4.70 \\
3.90 \\
3.20 \\
3.10 \\
3.00 \\
3.00 \\
2.90 \\
2.90 \\
2.90 \\
2.80 \\
2.80 \\
2.80 \\
2.70 \\
2.70 \\
2.70 \\
2.70 \\
3.00\end{array}$ & $\begin{array}{r}2.60 \\
2.50 \\
2.80 \\
2.90 \\
2.90 \\
3.00 \\
4.30 \\
7.70 \\
7.60 \\
3.80 \\
3.20 \\
3.10 \\
3.10 \\
3.80 \\
3.10 \\
3.50 \\
4.30 \\
5.60 \\
4.90 \\
3.50 \\
3.10 \\
3.00 \\
4.20 \\
13.00 \\
12.60 \\
7.00 \\
5.60 \\
4.60 \\
4.00 \\
4.50\end{array}$ & $\begin{array}{l}3.50 \\
3.30 \\
3.40 \\
3.20 \\
3.00 \\
2.90 \\
2.80 \\
2.80 \\
2.80 \\
2.70 \\
2.60 \\
2.90 \\
3.05 \\
3.55 \\
3.00 \\
2.90 \\
2.80 \\
2.70 \\
2.60 \\
2.60\end{array}$ & $\begin{array}{l}3.70 \\
3.80 \\
3.60 \\
3.60 \\
2.50 \\
2.50 \\
2.50 \\
2.40 \\
2.40 \\
2.30 \\
2.30 \\
2.30 \\
4.00 \\
2.50 \\
2.40 \\
2.40 \\
2.50 \\
2.50 \\
2.60 \\
2.40 \\
2.30 \\
2.20 \\
2.30 \\
2.20 \\
2.20 \\
2.60 \\
2.50 \\
2.20 \\
2.20 \\
2.90 \\
2.20\end{array}$ & $\begin{array}{l}2.30 \\
2.50 \\
2.50 \\
2.30 \\
2.20 \\
2.20 \\
2.10 \\
2.10 \\
2.10\end{array}$ & $\begin{array}{l}2.10 \\
2.10 \\
2.10 \\
2.20 \\
2.30 \\
2.50 \\
3.00 \\
2.60 \\
2.50 \\
2.40 \\
2.30 \\
2.30 \\
2.70 \\
2.60 \\
2.40 \\
2.30 \\
2.20 \\
2.20 \\
2.20 \\
2.20 \\
2.20 \\
2.10 \\
4.20 \\
5.00 \\
3.10 \\
4.00 \\
3.80 \\
3.10 \\
2.70 \\
2.50 \\
2.50\end{array}$ & $\begin{array}{l}2.40 \\
2.40 \\
6.50 \\
3.50 \\
2.80 \\
2.60 \\
2.50 \\
2.40 \\
2.40 \\
2.40 \\
2.40 \\
2.40 \\
2.30 \\
2.30 \\
2.30 \\
2.30 \\
2.30 \\
2.30 \\
2.40 \\
2.40 \\
2.40 \\
2.50 \\
2.40 \\
2.40 \\
3.60 \\
3.60 \\
2.80 \\
2.60 \\
2.50 \\
2.50\end{array}$ & 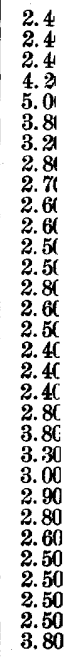 \\
\hline
\end{tabular}

OCONEE RIVER NEAR DUBLIN, GEORGIA.

This station was established by the United States Weather Bureau in 1894, was discontinued on April 30, 1897, and was reestablished by the Georgia geological survey on February 11, 1898. Since October 15, 1898, the station has been maintained by the United States Weather Bureau. It is located about a half mile east of Dublin, Georgia, and is described in Water-Supply Paper No. 36, page 133. Records of measurement will be found as follows: For 1898, Twentieth Annual Report, Part IV, page 170; for 1899, Twenty-first Annual Report, Part IV, page 136. During 1900 the following measurements of Oconee River at Dublin were made by B. M. Hall and his assistants :

April 12: Gage height, 4.25 feet; discharge, 4,680 second-feet.

December 7: Gage height, 7.30 feet; discharge, 7,991 second-feet. 
Daily gage height, in feet, of Oconee River near Dublin, Georgia, for 1900.

\begin{tabular}{|c|c|c|c|c|c|c|c|c|c|c|c|c|}
\hline D & Jan. & Feb. & Aar. & Apr. & May. & June. & July. & Ang. & Sept. & Oet. & Nov. & Dec. \\
\hline 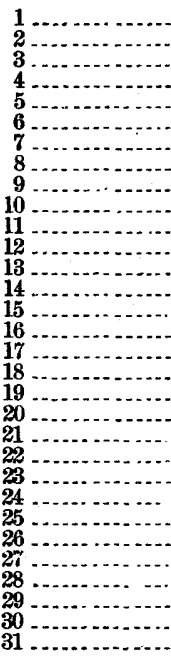 & $\begin{array}{l}2.4 \\
2.1 \\
1.8 \\
1.7 \\
1.6 \\
1.6 \\
1.5 \\
1.4 \\
1.2 \\
1.4 \\
1.9 \\
2.4 \\
4.3 \\
5.4 \\
5.7 \\
4.9 \\
3.3 \\
2.9 \\
.3 .8 \\
3.2 \\
4.1 \\
4.7 \\
4.4 \\
3.9 \\
3.3 \\
2.9 \\
2.4 \\
2.2 \\
2.0 \\
1.8 \\
1.7\end{array}$ & $\begin{array}{r}1.7 \\
1.6 \\
1.6 \\
1.6 \\
1.8 \\
3.4 \\
3.7 \\
3.5 \\
3.1 \\
3.5 \\
7.9 \\
10.2 \\
11.9 \\
16.4 \\
22.0 \\
24.4 \\
24.9 \\
24.1 \\
22.6 \\
20.0 \\
17.2 \\
14.0 \\
10.7 \\
9.1 \\
9.0 \\
8.7 \\
8.1 \\
7.4 \\
\hdashline \ldots . . \\
\hdashline \ldots . .\end{array}$ & $\begin{array}{r}8.0 \\
9.6 \\
10.4 \\
11.0 \\
11.7 \\
11.0 \\
9.0 \\
6.6 \\
5.8 \\
7.0 \\
8.0 \\
8.5 \\
8.7 \\
8.0 \\
7.1 \\
6.4 \\
8.1 \\
8.7 \\
9.0 \\
9.1 \\
8.5 \\
7.4 \\
7.8 \\
8.3 \\
8.9 \\
9.5 \\
9.6 \\
9.8 \\
10.2 \\
10.4 \\
10.2\end{array}$ & $\begin{array}{r}8.8 \\
6.5 \\
5.3 \\
4.8 \\
4.5 \\
4.5 \\
4.2 \\
4.0 \\
3.7 \\
3.5 \\
3.3 \\
3.9 \\
5.0 \\
5.9 \\
6.3 \\
5.0 \\
4.1 \\
3.4 \\
5.1 \\
8.2 \\
11.1 \\
15.6 \\
16.9 \\
17.6 \\
17.3 \\
17.0 \\
17.1 \\
16.0 \\
13.6 \\
11.4\end{array}$ & $\begin{array}{l}8.3 \\
6.4 \\
6.9 \\
7.3 \\
7.5 \\
6.7 \\
5.4 \\
4.1 \\
3.9 \\
3.3 \\
3.0 \\
2.7 \\
2.5 \\
2.3 \\
2.2 \\
2.1 \\
.4 .0 \\
1.9 \\
2.1 \\
3.7 \\
5.5 \\
5.3 \\
3.6 \\
3.1 \\
3.6 \\
5.8 \\
5.0 \\
3.4 \\
3.0 \\
2.2 \\
1.9\end{array}$ & $\begin{array}{r}1.6 \\
1.4 \\
1.3 \\
1.2 \\
1.9 \\
2.8 \\
4.1 \\
5.0 \\
6.0 \\
6.2 \\
6.2 \\
5.7 \\
4.3 \\
3.0 \\
2.9 \\
5.0 \\
7.5 \\
8.3 \\
9.9 \\
10.3 \\
10.6 \\
10.2 \\
7.9 \\
8.0 \\
9.0 \\
9.9 \\
11.6 \\
16.7 \\
20.0 \\
20.8\end{array}$ & $\begin{array}{l}1.2 \\
1.0 \\
2.4 \\
3.1 \\
2.1 \\
1.7 \\
1.7 \\
5.9 \\
5.2\end{array}$ & $\begin{array}{r}4.7 \\
5.0 \\
3.7 \\
2.9 \\
2.5 \\
1.9 \\
1.6 \\
1.6 \\
1.5 \\
1.3 \\
.7 \\
.4 \\
.2 \\
.1 \\
.3 \\
1.1 \\
.8 \\
.6 \\
.5 \\
.3 \\
.1 \\
.5 \\
.5 \\
.4 \\
.8 \\
1.3 \\
.9 \\
.7 \\
.5 \\
.5 \\
.8\end{array}$ & $\begin{array}{r}0.8 \\
2.7 \\
2.3 \\
2.1 \\
1.5 \\
1.2 \\
.5 \\
.4 \\
.2 \\
.2 \\
.0 \\
-.2 \\
.3 \\
.1 \\
.1 \\
.4 \\
4.8 \\
5.8 \\
6.0 \\
3.5 \\
1.9 \\
1.3 \\
.7 \\
.4 \\
.3 \\
.3 \\
.3 \\
.2 \\
.2 \\
0.0\end{array}$ & $\begin{array}{r}-0.1 \\
-.3 \\
.3 \\
-.2 \\
.0 \\
.8 \\
1.2 \\
.9 \\
1.1 \\
1.2 \\
1.0 \\
.8 \\
.6 \\
.7 \\
.6 \\
.6 \\
.6 \\
.5 \\
.2 \\
.1 \\
.1 \\
.0 \\
.0 \\
.7 \\
3.7 \\
5.6 \\
5.5 \\
3.0 \\
2.1 \\
1.9 \\
1.3\end{array}$ & $\begin{array}{r}1.0 \\
.9 \\
3.7 \\
4.7 \\
5.5 \\
6.5 \\
6.6 \\
4.8 \\
3.9 \\
2.6 \\
1.8 \\
1.3 \\
1.2 \\
1.0 \\
1.0 \\
.9 \\
.8 \\
.7 \\
.9 \\
.7 \\
.7 \\
1.1 \\
1.2 \\
.8 \\
.8 \\
.7 \\
1.7 \\
3.5 \\
5.3 \\
3.4\end{array}$ & $\begin{array}{l}2.3 \\
1.8 \\
1.6 \\
1.8 \\
3.2 \\
6.4 \\
7.2 \\
7.6 \\
6.8 \\
4.5 \\
3.3 \\
2.7 \\
2.3 \\
2.3 \\
5.2 \\
6.7 \\
8.1 \\
8.4 \\
6.4 \\
4.2 \\
4.6 \\
6.8 \\
7.7 \\
8.0 \\
8.2 \\
6.5 \\
4.8 \\
3.8 \\
3.4 \\
3.3 \\
8.4\end{array}$ \\
\hline
\end{tabular}

YELLOW RIVER AT ALMON, GEORGIA.

This station, which was established September 12, 1897, is described in Water-Supply Paper No. 36, page 134. During the year 1900 the bridge was washed away and a new bridge was built, but the gage was preserved and a new gage was referred to the same datum. It is attached to the post of a bridge bent near the left bank, and is referred to a bench mark on a sycamore tree on the left bank 40 yards above the bridge, a railroad spike in the tree being 7 feet above the zero of the gage. The gage was verified December 22, 1900. Records of measurements at this station during 1899 will be found in the Twentyfirst Annual Report, Part IV, page 137. During 1900 the following measurements of the discharge at Almon were made by B. M. Hall and his assistants:

April 19: Gage height, 9 feet; discharge, 3,295 second-feet.

November 30: Gage height, 2.40 feet; discharge, 341 second-feet.

December 22: Gage height, 4.50 feet; discharge, 966 second-feet. 
Daily gage height, in feet, of Yellow River at Almon, Georgia, for 1900.

\begin{tabular}{c|r|r|r|r|r|r|r|r|r|r|r|r}
\hline \multicolumn{1}{c|}{ Day. } & Jan. & Feb. & Mar. & Apr. & May. & June. & July. & Aug. & Sept. & Oct. & Nov. & Dec. \\
\hline & & & & & & & & & & & & \\
\hline 1 \\
2
\end{tabular}

TOWALIGA RIVER NEAR JULIETTE, GEORGIA.

This station was established on the Southern Railway bridge $2 \frac{1}{2}$ miles north of Juliette, Georgia, May 5, 1899, but observations of gage heights were not started until November 2, 1899. A description of the station will be found in Water-Supply Paper No. 36, page 136. Bench mark No. 1 is an iron girder 40 feet from the left end of the bridge and is 37.30 feet above gage datum. W. L. Jackson, a farmer living near the station (post-office address, Berner, Georgia), is the observer. Records of measurements made during 1899 will be found in Water-Supply Paper No. 36, page 136. During 1900 the following measurements were made by B. M. Hall and his assistants:

February 17: Gage height, 6.35 feet; discharge, 1,025 second-feet. April 3: Gage height, 2.60 feet; discharge, 348 second-feet.

December 8: Gage height, 2.75 feet; discharge, 468 second-feet. 
Daily gage height, in feet, of Towaliga River near Juliette, Georgia, for 1900.

\begin{tabular}{|c|c|c|c|c|c|c|c|c|c|c|c|c|}
\hline Day. & Jan. & Feb. & Mar. & Apr. & May. & June. & July. & Aug. & Sept. & Oct. & Nov. & Dec. \\
\hline $\begin{array}{r}1 \\
2 \\
3 \\
3 \\
4 \\
5 \\
6\end{array}$ & $\begin{array}{l}2.2 \\
2.2 \\
2.0 \\
2.0 \\
1.9 \\
1.9 \\
1.9 \\
1.9 \\
1.9 \\
1.9 \\
1.9 \\
2.7 \\
2.8 \\
2.3 \\
2.2 \\
2.1 \\
2.0 \\
2.1 \\
2.8 \\
3.2 \\
2.9 \\
2.5 \\
2.3 \\
2.2 \\
2.2 \\
2.1 \\
2.0 \\
2.1 \\
2.0 \\
2.0 \\
2.1\end{array}$ & $\begin{array}{r}2.0 \\
1.9 \\
1.9 \\
2.1 \\
2.7 \\
2.6 \\
2.3 \\
1.4 \\
2.4 \\
7.3 \\
11.8 \\
14.1 \\
14.8 \\
16.3 \\
16.3 \\
8.3 \\
4.8 \\
3.8 \\
3.3 \\
3.2 \\
2.4 \\
4.0 \\
3.3 \\
2.9 \\
.44 \\
3.0 \\
2.9 \\
2.4\end{array}$ & $\begin{array}{l}2.9 \\
4.3 \\
3.1 \\
2.8 \\
2.4 \\
2.4 \\
1.4 \\
2.9 \\
3.4 \\
2.8 \\
2.3 \\
1.3 \\
2.0 \\
1.1 \\
1.0 \\
4.0 \\
3.1 \\
2.3 \\
1.1 \\
3.3 \\
3.1 \\
2.3 \\
2.2 \\
2.7 \\
3.4 \\
4.0 \\
3.6 \\
2.8 \\
2.4 \\
2.4 \\
2.1\end{array}$ & $\begin{array}{r}1.8 \\
1.6 \\
2.6 \\
2.8 \\
2.6 \\
2.5 \\
2.7 \\
2.6 \\
2.5 \\
2.5 \\
3.4 \\
5.7 \\
4.0 \\
2.9 \\
2.8 \\
2.7 \\
2.7 \\
12.8 \\
17.8 \\
14.8 \\
7.8 \\
1.8 \\
5.5 \\
4.8 \\
4.1 \\
3.6 \\
3.4 \\
3.2 \\
3.3 \\
3.2\end{array}$ & $\begin{array}{l}3.1 \\
3.6 \\
4.9 \\
3.3 \\
3.1 \\
2.6 \\
2.6 \\
2.5 \\
2.5 \\
2.5 \\
2.4 \\
2.4 \\
2.4 \\
2.3 \\
2.3 \\
2.2 \\
2.2 \\
2.2 \\
2.2 \\
2.2 \\
2.2 \\
2.1 \\
2.1 \\
2.8 \\
2.9 \\
2.5 \\
2.4 \\
2.4 \\
2.2 \\
2.1 \\
2.1\end{array}$ & $\begin{array}{l}2.0 \\
2.1 \\
2.1 \\
3.7 \\
2.9 \\
2.5 \\
3.2 \\
5.2 \\
2.4 \\
2.6 \\
2.9 \\
2.3 \\
2.3 \\
2.4 \\
2.3 \\
2.9 \\
3.3 \\
3.8 \\
4.1 \\
5.2 \\
2.2 \\
1.9 \\
2.2 \\
9.8 \\
10.8 \\
8.8 \\
6.8 \\
6.6 \\
6.2 \\
4.2\end{array}$ & $\begin{array}{l}4.0 \\
4.0 \\
3.5 \\
3.5 \\
4.1 \\
3.5 \\
3.3 \\
4.2 \\
4.0 \\
4.0 \\
3.8 \\
3.7 \\
4.4 \\
3.7 \\
2.2 \\
2.0 \\
1.8 \\
1.0 \\
1.0 \\
1.0 \\
1.0 \\
1.5 \\
2.2 \\
1.9 \\
1.6 \\
2.4 \\
2.5 \\
4.0 \\
5.1 \\
3.4\end{array}$ & $\begin{array}{l}2.2 \\
2.2 \\
1.7 \\
1.7 \\
2.3 \\
1.7 \\
1.5 \\
1.3 \\
1.2 \\
1.2 \\
1.2 \\
1.1 \\
1.3 \\
1.0 \\
1.7 \\
1.5 \\
1.3 \\
1.3 \\
1.2 \\
1.1 \\
0.8 \\
0.9 \\
2.1 \\
3.0 \\
4.3 \\
2.6 \\
1.5 \\
1.2 \\
1.6 \\
5.5\end{array}$ & $\begin{array}{l}4.5 \\
1.5 \\
1.9 \\
1.6 \\
1.5 \\
1.3 \\
1.2 \\
1.0 \\
1.0 \\
1.0 \\
1.0 \\
1.0 \\
1.0 \\
2.4 \\
8.0 \\
6.4 \\
4.2 \\
3.1 \\
2.9 \\
2.0 \\
1.4 \\
1.3 \\
1.2 \\
1.3 \\
1.2 \\
1.2 \\
1.1 \\
1.1 \\
0.8\end{array}$ & $\begin{array}{l}0.9 \\
1.0 \\
1.4 \\
2.1 \\
3.4 \\
3.6 \\
3.9 \\
3.8 \\
1.7 \\
1.5 \\
1.5 \\
1.6 \\
1.7 \\
1.7 \\
1.4 \\
1.3 \\
1.1 \\
1.1 \\
1.1 \\
1.1 \\
2.4 \\
3.6 \\
3.5 \\
2.9 \\
2.1 \\
1.5 \\
1.2 \\
1.2\end{array}$ & $\begin{array}{l}1.3 \\
2.0 \\
8.2 \\
7.0 \\
6.4 \\
3.5 \\
2.2 \\
2.1 \\
2.1 \\
2.0 \\
2.0 \\
1.9 \\
1.9 \\
1.9 \\
1.9 \\
1.8 \\
1.8 \\
1.8 \\
2.0 \\
1.9 \\
1.8 \\
1.8 \\
1.9 \\
1.9 \\
2.5 \\
4.4 \\
3.1 \\
2.4 \\
2.3 \\
1.9\end{array}$ & $\begin{array}{l}1 . \\
4 . \\
4 \\
3 . \\
3 . \\
3 . \\
2 . \\
2 . \\
2 . \\
2 . \\
2 . \\
2 . \\
9 . \\
7 . \\
4 . \\
3 . \\
3 . \\
2 . \\
6 . \\
7 . \\
\mathbf{5} . \\
3 . \\
3 . \\
2 . \\
\mathbf{2} \\
\mathbf{2} . \\
\mathbf{2} \\
\mathbf{2} . \\
\mathbf{3} \\
\mathbf{4} .\end{array}$ \\
\hline
\end{tabular}

OCMULGEe RIVER AT MACON, GEORGIA.

This station was established by the United States Weather Bureau January 21,1893 , and measurements were begun by the United States Geological Survey in 1895. The station is described in Water-Supply Paper No. 36,"page 136. During the year $1900 \mathrm{Mr}$. T. S. Collins, of the United States Weather Bureau, put in a new gage on the center pier of the bridge on which the old gage was placed, and referred it to the same datum as the old gage. The old gage is still in place, is in good condition, and is still used except during low water, when mud accumulates around its base at a higher level than the river. The new gage was put in to save cleaning away the mud from the bottom of the old gage. Records of measurements for 1899 will be found in the Twenty-first Annual Report, Part IV, page 139. During 1900 the following measurements were made by B. M. Hall and his assistants:

April 13: Gage height, 7.38 feet; discharge, 4,855 second-feet.

November 20: Gage height, 2.40 feet: discharge, 1,369 second-feet.

December 6: Gage height, 8.65 feet; discharge, 5,698 second-feet.

December 21: Gage height, 12.82 feet; discharge, 9,621 second-feet. 
OPERATIONS AT R̈IVER ŚTATIONS, 1900.-DAR̃T II. [No. 48.

Daily gage height, in feet, of Ocmulgee River at Macon, Georgia, for 1900.

\begin{tabular}{|c|c|c|c|c|c|c|c|c|c|c|c|c|}
\hline Day. & Jan. & Feb. & Mar. & Apr. & May. & June. & July. & Aug. & Sept. & Oct. & Novi. & Dec \\
\hline $\begin{array}{l}4 \\
5 \\
6 \\
7 \\
8 \\
9 \\
9\end{array}$ & $\begin{array}{l}1.6 \\
1.5 \\
1.2 \\
1.2 \\
1.2 \\
1.5 \\
1.4 \\
1.4 \\
1.3 \\
1.3 \\
1.9 \\
2.9 \\
4.2 \\
3.7 \\
2.6 \\
2.2 \\
2.0 \\
2.0 \\
2.9 \\
3.8 \\
4.6 \\
3.9 \\
3.1 \\
2.7 \\
2.5 \\
2.2 \\
2.0 \\
2.0 \\
1.9 \\
1.7 \\
1.6\end{array}$ & $\begin{array}{r}1.6 \\
1.5 \\
1.5 \\
1.5 \\
2.8 \\
2.9 \\
2.5 \\
2.3 \\
3.2 \\
8.3 \\
16.1 \\
18.7 \\
19.0 \\
11.7 \\
19.5 \\
11.4 \\
8.5 \\
7.4 \\
6.8 \\
8.2 \\
8.9 \\
7.7 \\
6.4 \\
7.3 \\
6.5 \\
5.9 \\
5.5\end{array}$ & $\begin{array}{r}9.2 \\
9.4 \\
7.7 \\
6.2 \\
5.8 \\
5.5 \\
5.3 \\
77.0 \\
7.8 \\
9.7 \\
8.1 \\
6.4 \\
5.8 \\
5.3 \\
5.3 \\
10.4 \\
7.3 \\
5.8 \\
5.2 \\
8.0 \\
7.7 \\
6.6 \\
5.6 \\
7.3 \\
7.9 \\
10.5 \\
10.9 \\
7.8 \\
7.4 \\
6.6 \\
5.8\end{array}$ & $\begin{array}{r}5.2 \\
4.9 \\
4.8 \\
4.6 \\
4.5 \\
4.5 \\
4.3 \\
4.3 \\
4.1 \\
4.1 \\
4.3 \\
7.0 \\
7.6 \\
6.1 \\
5.3 \\
4.8 \\
4.3 \\
5.0 \\
18.0 \\
15.6 \\
13.9 \\
16.0 \\
13.9 \\
13.2 \\
13.0 \\
12.4 \\
9.8 \\
7.6 \\
7.0 \\
6.3\end{array}$ & $\begin{array}{l}6.1 \\
7.3 \\
8.6 \\
8.0 \\
7.3 \\
6.4 \\
5.6 \\
4.4 \\
4.1 \\
4.1 \\
4.1 \\
4.0 \\
3.9 \\
3.8 \\
3.6 \\
3.4 \\
3.4 \\
3.3 \\
4.1 \\
4.0 \\
3.7 \\
3.5 \\
3.3 \\
4.6 \\
4.8 \\
4.2 \\
3.8 \\
3.3 \\
3.1 \\
3.0 \\
2.9\end{array}$ & $\begin{array}{r}2.9 \\
2.9 \\
3.2 \\
3.8 \\
4.6 \\
6.4 \\
8.0 \\
8.9 \\
7.7 \\
6.6 \\
5.5 \\
5.2 \\
3.8 \\
3.7 \\
3.2 \\
8.6 \\
8.8 \\
10.9 \\
11.2 \\
8.0 \\
5.3 \\
4.0 \\
4.0 \\
160 \\
20.2 \\
20.0 \\
16.4 \\
14.0 \\
12.7 \\
10.4\end{array}$ & $\begin{array}{r}9.6 \\
8.3 \\
13.3 \\
11.2 \\
8.3 \\
6.4 \\
5.5 \\
4.9 \\
5.0 \\
4.5 \\
4.3 \\
4.8 \\
5.3 \\
4.9 \\
4.5 \\
4.0 \\
3.9 \\
3.7 \\
3.5 \\
3.5 \\
3.4 \\
3.3 \\
3.4 \\
3.9 \\
3.4 \\
3.3 \\
4.2 \\
4.5 \\
5.6 \\
6.3 \\
8.0\end{array}$ & $\begin{array}{l}6.4 \\
4.4 \\
4.2 \\
3.7 \\
3.4 \\
3.1 \\
30 \\
2.8 \\
2.6 \\
2.5 \\
24 \\
2.3 \\
2.4\end{array}$ & $\begin{array}{r}10.5 \\
5.8 \\
5.0 \\
3.5 \\
2.7 \\
2.5 \\
2.4 \\
2.1 \\
2.2 \\
2.1 \\
2.0 \\
2.0 \\
1.8 \\
1.7 \\
4.7 \\
13.3 \\
10.5 \\
6.0 \\
4.0 \\
3.3 \\
2.7 \\
2.5 \\
2.4 \\
2.3 \\
2.3 \\
2.2 \\
2.0 \\
2.0 \\
2.0 \\
1.9\end{array}$ & $\begin{array}{l}1.8 \\
1.8 \\
1.7 \\
2.2 \\
4.1 \\
3.6 \\
5.0 \\
4.6 \\
2.7 \\
3.2 \\
2.6 \\
2.5 \\
2.4 \\
2.7 \\
2.6 \\
2.4 \\
2.2 \\
2.1 \\
2.0 \\
1.9 \\
1.9 \\
1.9 \\
2.1 \\
8.3 \\
4.2 \\
3.7 \\
2.9 \\
2.5 \\
2.4 \\
2.3 \\
2.1\end{array}$ & $\begin{array}{r}2.0 \\
3.2 \\
2.8 \\
12.3 \\
8.2 \\
4.9 \\
3.6 \\
3.2 \\
2.8 \\
2.6 \\
2.5 \\
2.4 \\
2.3 \\
2.2 \\
2.2 \\
2.2 \\
2.1 \\
2.1 \\
2.1 \\
2.0 \\
2.4 \\
2.4 \\
2.5 \\
2.7 \\
2.5 \\
7.1 \\
5.5 \\
4.3 \\
3.2 \\
2.9\end{array}$ & $\begin{array}{r}3.9 \\
4.0 \\
12.8 \\
12.1 \\
8.6 \\
6.5 \\
5.5 \\
4.8 \\
4.1\end{array}$ \\
\hline
\end{tabular}

FLINT RIVER AT ALBANY, GEORGIA.

This station, which is described in Water-Supply Paper No. 36, page 138, was originally established by the United States Weather Bureau on April 10, 1893, and has been maintained from that date to the present time. In 1898 the gage was washed out by a freshet, but soon afterwards it was replaced. The present rod is located at the foot of Broad street, just below the county bridge. It is a pine board, and is in two sections. The first section, which reads from 0 to 18.6 feet, is spiked to a cypress stump which stands at the edge of the water; the second section, which reads from 18.7 feet to 30 feet, is spiked to a cypress pole. The bench marks are as follows: (1) The top of the rail at the railroad station of the Plant System, being 42.2 feet above the zero of the gage and 184 feet above mean sea level, making the elevation of the zero of the rod 141.8 feet above sea level; (2) a cut in the lower iron pier of the county bridge 10 feet above gage datum and 151.8 feet above mean sea level; and (3) a spike in the corner of Mase \& Company's warehouse, corner of Broad and Front streets, 53.8 feet above gage datum. The highest water recorded was on March 25, 1897, when the height of 31.6 feet was reached, and the lowest point recorded since the commencement of the record was on October 9,1895 , when the reading was -0.9 foot. The danger line is at 20 feet. Discharge measurements are made at the county highway bridge in Albany, a steel structure in two spans of 130 feet each, with two approaches of 315 and 205 feet, respectively. 
Kinchatoonee and Muckalee creeks are two important tributaries of Flint River. They unite about 2 miles north of Albany, forming Big Muckalee Creek, which enters Flint River on the west side within the city limits. There is a wagon bridge over the Kinchafoonee about 1 mile above its junction with the Muckalee, and a similar bridge on the Muckalee $1 \frac{3}{4}$ miles above its mouth and about 300 yards - below the mouth of the Kinchafoonee. Measurements will be made at these bridges whenever Flint River is measured at Albany. No discharge measurements were made at this point during 1900 or in previous years, but measurements will be made during 1901 .

Daily gage height, in feet, of Flint River at Albany, Georgia, for 1900 .

\begin{tabular}{|c|c|c|c|c|c|c|c|c|c|c|c|c|}
\hline Day. & Jan. & Feb. & Mar. & Apr. & May. & June. & July. & Aug. & Sept. & Oct. & Nov. & Dec. \\
\hline $\begin{array}{r}1 \\
2 \\
2 \\
3 \\
4 \\
4\end{array} \ldots$ & $\begin{array}{l}4.7 \\
4.3 \\
3.0 \\
3.3 \\
2.9 \\
2.6 \\
2.3 \\
1.7 \\
1.3 \\
1.2 \\
1.2 \\
1.7 \\
2.3 \\
2.8 \\
3.3 \\
3.1 \\
2.9 \\
2.8 \\
2.8 \\
2.9 \\
3.0 \\
3.3 \\
3.4 \\
3.7 \\
3.5 \\
3.1 \\
2.5 \\
2.2 \\
2.0 \\
1.9 \\
1.3\end{array}$ & $\begin{array}{r}1.8 \\
1.9 \\
2.3 \\
2.3 \\
2.6 \\
2.9 \\
3.4 \\
3.8 \\
4.8 \\
6.4 \\
9.8 \\
14.3 \\
18.1 \\
20.0 \\
21.3 \\
22.4 \\
26.2 \\
29.0 \\
29.0 \\
26.1 \\
23.1 \\
21.0 \\
17.2 \\
13.3 \\
11.2 \\
9.0 \\
9.0\end{array}$ & $\begin{array}{l}9.1 \\
9.2 \\
9.3 \\
9.5 \\
9.6 \\
9.3 \\
9.2 \\
8.9 \\
9.1 \\
9.2 \\
9.1 \\
9.0 \\
8.9 \\
8.9 \\
9.7 \\
10.5 \\
10.8 \\
11.2 \\
11.2 \\
12.1 \\
12.2 \\
12.1 \\
12.2 \\
12.2 \\
16.3 \\
16.9 \\
16.0 \\
15.1 \\
13.4 \\
11.6\end{array}$ & $\begin{aligned} 11.1 \\
10.0 \\
9.1 \\
8.3 \\
7.2 \\
6.1 \\
5.9 \\
5.4 \\
4.7 \\
4.3 \\
4.3 \\
4.3 \\
4.5 \\
4.7 \\
4.9 \\
5.4 \\
5.9 \\
7.8 \\
8.6 \\
10.7 \\
11.2 \\
12.1 \\
13.6 \\
14.3 \\
14.9 \\
15.2 \\
12.1 \\
11.3 \\
9.0 \\
8.9\end{aligned}$ & $\begin{array}{l}9.4 \\
10.2 \\
11.1 \\
11.0 \\
10.3 \\
9.7 \\
6.2 \\
4.7 \\
3.8 \\
3.9 \\
4.5 \\
4.9 \\
5.2 \\
5.2 \\
5.1 \\
4.6 \\
4.1 \\
3.8 \\
3.1 \\
2.6 \\
2.4 \\
2.0 \\
2.0 \\
1.9 \\
1.7 \\
1.4 \\
1.3 \\
1.2 \\
1.0 \\
1.0\end{array}$ & $\begin{array}{r}1.1 \\
1.3 \\
1.3 \\
1.2 \\
1.4 \\
1.7 \\
2.1 \\
2.5 \\
2.9 \\
3.5 \\
3.5 \\
3.6 \\
3.8 \\
4.3 \\
3.4 \\
2.0 \\
2.1 \\
2.4 \\
2.4 \\
2.4 \\
2.5 \\
2.8 \\
2.9 \\
3.3 \\
3.9 \\
4.2 \\
5.3 \\
7.5 \\
8.2 \\
1.5\end{array}$ & $\begin{aligned} 15.8 \\
16.0 \\
16.0 \\
15.2 \\
13.0 \\
10.3 \\
2.0 \\
6.1 \\
5.3 \\
4.9 \\
4.0 \\
3.8 \\
4.4 \\
4.9 \\
5.0 \\
5.4 \\
5.8 \\
4.6 \\
3.1 \\
2.4 \\
1.6 \\
1.4 \\
1.5 \\
1.6 \\
1.4 \\
1.7 \\
1.6 \\
1.9 \\
2.7 \\
2.9 \\
3.9\end{aligned}$ & $\begin{array}{r}4.2 \\
4.2 \\
3.8 \\
3.4 \\
2.8 \\
2.2 \\
1.6 \\
1.0 \\
.8 \\
1.2 \\
1.0 \\
.8 \\
.8 \\
.8 \\
.9 \\
1.0 \\
1.2 \\
1.2 \\
1.4 \\
1.2 \\
1.0 \\
.9 \\
.9 \\
.9 \\
.8 \\
.8 \\
9 \\
1.1\end{array}$ & $\begin{array}{l}1.3 \\
1.5 \\
1.9 \\
2.4 \\
2.9 \\
3.4 \\
3.7 \\
3.7 \\
3.8 \\
3.6 \\
3.7 \\
3.6 \\
3.7 \\
3.9 \\
4.3 \\
4.5 \\
4.6 \\
4.6 \\
4.3 \\
4.1 \\
3.7 \\
3.5 \\
3.5 \\
3.1 \\
2.7 \\
2.3 \\
1.1 \\
1.0 \\
1.0 \\
.9\end{array}$ & $\begin{array}{l}0.9 \\
1.0 \\
1.0 \\
1.2 \\
1.6 \\
1.9 \\
2.1 \\
2.9 \\
3.1 \\
3.1 \\
3.1 \\
3.7 \\
3.9 \\
4.1 \\
4.5 \\
4.2 \\
4.2 \\
4.3 \\
4.3 \\
4.2 \\
4.3 \\
4.3 \\
4.4 \\
4.5 \\
4.2 \\
4.0 \\
3.7 \\
3.6 \\
3.4 \\
3.2 \\
3.1\end{array}$ & $\begin{array}{r}3.0 \\
3.4 \\
3.7 \\
3.9 \\
4.6 \\
5.7 \\
4.8 \\
4.9 \\
5.6 \\
3.7 \\
2.9 \\
2.1 \\
1.7 \\
1.3 \\
1.2 \\
1.2 \\
1.1 \\
.9 \\
.9 \\
1.9 \\
1.3 \\
1.4 \\
1.5 \\
1.7 \\
2.2 \\
2.4 \\
2.7 \\
2.7 \\
2.8\end{array}$ & $\begin{array}{r}2.5 \\
1.9 \\
1.8 \\
2.3 \\
2.7 \\
2.9 \\
3.4 \\
3.8 \\
4.1 \\
4.7 \\
5.2 \\
6.1 \\
6.9 \\
7.1 \\
7.1 \\
7.4 \\
7.4 \\
7.8 \\
8.2 \\
8.5 \\
8.9 \\
8.9 \\
9.1 \\
9.0 \\
9.0 \\
8.7 \\
8.6 \\
8.4 \\
8.9 \\
9.4 \\
10.3\end{array}$ \\
\hline
\end{tabular}

FLINT RIVER AT WOODBURY, GEORGIA.

Measurements of the flow of Flint River were made during 1897 and 1898 at Molina, Georgia, but the river bed was so shifting that the station was discontinued on June 2, 1898. Records of the measurements made at Molina will be found as follows: For 1897, Nineteenth Annual Report, Part IV, page 234; for 1898, Twentieth Annual Report, Part IV, page 233. A gage has been maintained at Albany, Georgia, by the United States Weather Bureau, as described in WaterSupply Paper No. 36, page 138. Two measurements were made in 1899 at the Macon and Birmingham bridge near Woodbury, Georgia, 5 miles below the Molina station. On March 29, 1900, a gage was put in near this bridge, and the station was reestablished. The gage is a vertical rod fastened to a willow tree on the left bank of the river about 300 feet above the bridge, and is referred to the bench mark 
(the top of the iron girder under the cross-ties at a point 12 feet to the left of the center pier), which is 27 feet above the zero of the gage, the zero of the gage being 659.6 feet above sea level. This gage was maintained by the Georgia geological survey until November 1, 1900, when it was adopted by the United States Weather Bureau as a halfyear station, instead of the one at Reynolds, Georgia. During 1900 the following measurements were made by B. M. Hall and his assistants: *

March 29: Gage height, 2.20 feet; discharge, 2,329 second-feet.

May 2: Gage height, 2.85 feet; discharge, 3,220 second-feet.

December 12: Gage height, 0.85 foot; discharge, 998 second-feet.

December 21: Gage height, 4.35 feet; discharge, 5,423 second-feet.

Daily gage height, in feet, of Flint River at Woodbury, Georgia, for 1900.

\begin{tabular}{|c|c|c|c|c|c|c|c|c|c|c|}
\hline Day. & Mar. & Apr. & May. & June. & July. & Aug. & Sept. & Oct. & Nov. & Dec. \\
\hline $\begin{array}{r}2 \\
3 \\
4\end{array} 5$ & $\begin{array}{l} \\
\end{array}$ & $\begin{array}{l}1.3 \\
1.2 \\
1.2 \\
1.1 \\
1.1 \\
1.1 \\
1.0 \\
1.0 \\
1.0 \\
1.2 \\
1.3 \\
2.1 \\
2.4 \\
2.1 \\
1.6 \\
1.4 \\
1.2 \\
2.0 \\
4.6 \\
5.2 \\
5.8 \\
5.0 \\
2.8 \\
2.6 \\
2.4 \\
2.2 \\
1.9 \\
1.5 \\
1.2\end{array}$ & $\begin{array}{r}1.9 \\
1.5 \\
1.3 \\
1.4 \\
1.2 \\
1.0 \\
.9 \\
.8 \\
.7 \\
.8 \\
.6 \\
.7 \\
.7 \\
.6 \\
.6 \\
.5 \\
.6 \\
.5 \\
1.0 \\
.8 \\
.7 \\
.5 \\
1.0 \\
1.5 \\
1.3 \\
.9 \\
.7 \\
.6 \\
.5 \\
.5\end{array}$ & $\begin{array}{r}0.6 \\
.5 \\
.6 \\
1.0 \\
1.4 \\
1.6 \\
1.5 \\
1.8 \\
1.8 \\
1.6 \\
1.0 \\
.7 \\
.6 \\
.5 \\
1.0 \\
4.1 \\
4.0 \\
.8 \\
6.0 \\
5.0 \\
2.4 \\
.40 \\
9.0 \\
8.5 \\
8.0 \\
7.0 \\
5.9 \\
5.1 \\
4.1\end{array}$ & $\begin{array}{l}2.9 \\
2.8 \\
4.5 \\
4.3 \\
3.7 \\
2.4 \\
1.8 \\
1.4 \\
1.1 \\
1.0 \\
.9 \\
1.6 \\
1.5 \\
1.6 \\
1.3 \\
1.0 \\
.8 \\
.7 \\
.6 \\
.5 \\
.8 \\
.6 \\
1.1 \\
.8 \\
1.0 \\
1.2 \\
1.2 \\
1.6 \\
2.4 \\
3.0\end{array}$ & $\begin{array}{l}2.5 \\
1.7 \\
1.2 \\
1.0 \\
1.2 \\
.8 \\
.6 \\
.5 \\
.4 \\
.4 \\
.3 \\
.3 \\
.7 \\
.4 \\
.3 \\
.4 \\
.4 \\
.5 \\
.4 \\
.3 \\
.3 \\
.2 \\
.1 \\
.2 \\
.1 \\
.3 \\
.3 \\
.2 \\
.2 \\
.3 \\
.4\end{array}$ & $\begin{array}{r}0.4 \\
.7 \\
.6 \\
.4 \\
.3 \\
.2 \\
.2 \\
.2 \\
.1 \\
.1 \\
.2 \\
.1 \\
.1 \\
1.3 \\
1.6 \\
1.5 \\
1.3 \\
1.1 \\
.8 \\
.4 \\
.3 \\
.3 \\
.2 \\
.3 \\
.2 \\
.2 \\
.2 \\
.2 \\
.1\end{array}$ & $\begin{array}{r}0.2 \\
.1 \\
.2 \\
.5 \\
1.5 \\
1.8 \\
1.2 \\
1.0 \\
1.8 \\
.7 \\
.5 \\
.5 \\
.6 \\
.6 \\
.5 \\
.4 \\
.4 \\
.3 \\
.2 \\
.2 \\
.3 \\
.3 \\
.6 \\
.9 \\
1.0 \\
1.1 \\
.7 \\
.5 \\
.4 \\
.4 \\
.3\end{array}$ & $\begin{array}{r}0.4 \\
1.2 \\
2.0 \\
3.3 \\
2.8 \\
1.3 \\
1.0 \\
.8 \\
.7 \\
.6 \\
.5 \\
.6 \\
.5 \\
.5 \\
.5 \\
.5 \\
.5 \\
.6 \\
.5 \\
.6 \\
.7 \\
.6 \\
.7 \\
1.7 \\
1.6 \\
1.2 \\
1.0 \\
.8\end{array}$ & $\begin{array}{r}0.7 \\
.6 \\
1.5 \\
2.8 \\
2.1 \\
1.8 \\
1.4 \\
1.3 \\
1.0 \\
.9 \\
.8 \\
2.8 \\
3.3 \\
2.7 \\
2.1 \\
1.6 \\
1.3 \\
2.1 \\
4.3 \\
3.9 \\
3.5 \\
2.8 \\
2.1 \\
1.7 \\
1.4 \\
1.3 \\
1.2 \\
1.3 \\
2.2\end{array}$ \\
\hline
\end{tabular}

CHATTAHOOCHEE RIVER AT OAKDALE, GEORGIA.

Two gaging stations are maintained on Chattahoochee River, one at Oakdale, 8 miles northwest of Atlanta, and the other at West Point, Georgia, where the river reaches the Alabama State line. The station at Oakdale was established October 17, 1895, and is described in Water-Supply Paper No. 36, page 139. The results of measurements during 1899 will be found in the Twenty-first Annual Report, Part IV, page 140. During 1900 the following measurements were made by B. M. Hall and his assistants:

January 4: Gage height, 1.53 feet; discharge, 1,784 second-feet.

March 27: Gage height, 5.85 feet; discharge, 5,504 second-feet.

July 6: Gage height, 4 feet; discharge, 3,886 second-feet.

September 12: Gage height, 1.08 feet; discharge, 1,456 second-feet.

November 29: Gage height, 2.32 feet; discharge, 2,334 second-feet. 
Daily gage height, in feet, of Chattahoochee River at Oakdale, Georgia, for 1900.

\begin{tabular}{|c|c|c|c|c|c|c|c|c|c|c|c|c|}
\hline Day. & Jan. & Feb. & Mar. & Apr. & May. & June. & July. & Aug. & Sept. & Oct. & Nov. & Dec. \\
\hline 0 & $\begin{array}{r}1.0 \\
.7 \\
.5 \\
.5 \\
.9 \\
1.2 \\
1.3 \\
1.2 \\
1.1 \\
2.0 \\
3.9 \\
3.0 \\
2.8 \\
2.2 \\
1.9 \\
1.7 \\
2.8 \\
4.9 \\
5.0 \\
4.8 \\
2.9 \\
3.0 \\
2.6 \\
1.9 \\
1.7 \\
1.5 \\
1.5 \\
1.4 \\
1.3\end{array}$ & $\begin{array}{r}1.0 \\
1.0 \\
.9 \\
2.9 \\
3.9 \\
3.5 \\
2.2 \\
1.9 \\
3.8 \\
4.3 \\
7.4 \\
8.0 \\
15.5 \\
20.7 \\
16.4 \\
6.0 \\
4.8 \\
3.8 \\
3.5 \\
3.1 \\
3.0 \\
4.2 \\
4.3 \\
3.8 \\
4.1 \\
4.0 \\
3.3 \\
3.0\end{array}$ & $\begin{array}{l}4.5 \\
5.9 \\
4.3 \\
3.6 \\
3.3 \\
3.1 \\
3.0 \\
8.8 \\
7.9 \\
6.9 \\
5.5 \\
4.0 \\
3.1 \\
3.2 \\
3.0 \\
5.0 \\
3.6 \\
3.0 \\
4.5 \\
5.9 \\
6.6 \\
4.8 \\
4.1 \\
3.5 \\
7.7 \\
7.5 \\
6.0 \\
4.5 \\
4.0 \\
3.8 \\
3.5\end{array}$ & $\begin{array}{r}3.4 \\
3.1 \\
3.0 \\
2.7 \\
2.7 \\
2.8 \\
2.8 \\
2.7 \\
2.7 \\
2.6 \\
3.0 \\
6.4 \\
5.4 \\
4.2 \\
3.8 \\
3.3 \\
4.0 \\
6.9 \\
9.0 \\
7.3 \\
6.3 \\
7.0 \\
6.3 \\
13.6 \\
7.5 \\
6.0 \\
5.5 \\
5.0 \\
5.0 \\
5.0\end{array}$ & $\begin{array}{l}5.0 \\
4.8 \\
4.5 \\
4.0 \\
3.9 \\
3.0 \\
3.0 \\
3.0 \\
.99 \\
2.9 \\
2.8 \\
2.7 \\
2.7 \\
2.6 \\
2.6 \\
2.6 \\
2.5 \\
3.5 \\
3.7 \\
3.0 \\
3.1 \\
3.2 \\
3.7 \\
3.9 \\
3.7 \\
3.5 \\
3.4 \\
3.2 \\
3.0 \\
2.5 \\
2.4\end{array}$ & $\begin{array}{r}3.0 \\
3.7 \\
4.0 \\
4.7 \\
4.0 \\
3.8 \\
4.7 \\
9.7 \\
10.5 \\
8.0 \\
5.0 \\
4.0 \\
4.5 \\
4.0 \\
3.5 \\
3.0 \\
3.5 \\
4.5 \\
6.0 \\
6.5 \\
8.0 \\
9.0 \\
13.6 \\
18.0 \\
17.5 \\
11.4 \\
10.5 \\
7.5 \\
6.0 \\
5.5\end{array}$ & $\begin{array}{r}5.0 \\
4.5 \\
6.0 \\
7.5 \\
7.0 \\
6.5 \\
6.4 \\
6.0 \\
5.8 \\
5.7 \\
5.6 \\
5.4 \\
5.2 \\
4.0 \\
4.4 \\
4.3 \\
4.2 \\
4.1 \\
4.0 \\
3.9 \\
3.8 \\
3.7 \\
3.7 \\
4.0 \\
5.0 \\
6.0 \\
6.5 \\
7.4 \\
10.0 \\
6.0\end{array}$ & $\begin{array}{l}5.0 \\
4.5 \\
4.0 \\
4.0 \\
4.0 \\
3.5 \\
3.5 \\
3.5 \\
3.0 \\
3.0 \\
3.0 \\
3.0 \\
3.0 \\
3.0 \\
3.0 \\
2.7 \\
3.0 \\
4.0 \\
3.5 \\
3.5 \\
3.0 \\
3.0 \\
3.0 \\
2.7 \\
2.7 \\
2.6 \\
2.5 \\
3.0 \\
3.0 \\
2.7\end{array}$ & $\begin{array}{r}2.0 \\
2.0 \\
2.0 \\
1.9 \\
1.7 \\
1.8 \\
1.8 \\
1.8 \\
1.7 \\
1.7 \\
1.5 \\
1.5 \\
4.3 \\
8.4 \\
10.2 \\
8.2 \\
6.0 \\
3.1 \\
3.0 \\
2.8 \\
2.8 \\
2.7 \\
2.5 \\
2.3 \\
2.3 \\
2.0 \\
2.0 \\
1.8 \\
1.5 \\
1.5\end{array}$ & $\begin{array}{l}2.1 \\
2.1 \\
2.1 \\
3.0 \\
3.4 \\
3.8 \\
4.0 \\
4.0 \\
3.9 \\
3.5 \\
3.5 \\
3.9 \\
4.3 \\
4.2 \\
4.0 \\
3.6 \\
3.4 \\
3.2 \\
3.0 \\
3.0 \\
2.8 \\
3.0 \\
3.3 \\
3.3 \\
3.0 \\
3.0 \\
2.9 \\
2.8 \\
2.6 \\
2.4 \\
2.4\end{array}$ & $\begin{array}{l}2.4 \\
2.4 \\
3.0 \\
2.8 \\
2.7 \\
2.5 \\
2.5 \\
2.5 \\
2.4 \\
2.4 \\
2.4 \\
2.4 \\
2.3 \\
2.2 \\
2.1 \\
2.1 \\
2.0 \\
2.0 \\
1.8 \\
1.5 \\
1.5 \\
1.8 \\
2.0 \\
1.9 \\
1.8 \\
1.8 \\
5.6 \\
3.3 \\
2.3 \\
2.0\end{array}$ & $\begin{array}{l}2.2 \\
2.2 \\
2.1 \\
2.3 \\
4.1 \\
4.0 \\
4.0 \\
3.8 \\
3.7 \\
3.5 \\
2.1 \\
2.0 \\
2.0 \\
2.3 \\
2.3 \\
2.2 \\
2.1 \\
2.1 \\
2.0 \\
2.3 \\
2.6 \\
2.8 \\
2.7 \\
3.0 \\
2.8 \\
2.7 \\
2.5 \\
2.3 \\
2.3 \\
3.0 \\
3.8\end{array}$ \\
\hline
\end{tabular}

CHATTAHOOCHEE RIVER AT WEST POINT, GEORGIA.

This station was established July 30,1896 , on the highway bridge in West Point, Georgia, about 500 feet below the railroad bridge. It is described in Water-Supply Paper No. 36, page 142. The gage was last verified December 4, 1900. The observer is C. E. Melton. The results of measurements during 1899 will be found in the Twenty-first Annual Report, Part IV, page 141. During.1900 the following measurements were made by B. M. Hall and his assistants:

January 20: Gage height, 4.65 feet; discharge, 6,574 second-feet.

February 24: Gage height, 4.92 feet; discharge, 7,158 second-feet.

August 22: Gage height, 2.80 feet; discharge, 2,755 second-feet.

December 4: Gage height, 3.93 feet; discharge, 5,224 second-feet. 
Daily gage height, in feet, of Chattahoochee River at West Point, Georgia, for 1900.

\begin{tabular}{|c|c|c|c|c|c|c|c|c|c|c|c|c|}
\hline Day. & Jan. & Feb. & Mar. & Apr. & May. & June. & July. & Aug. & Sept. & Oct. & Noy. & Dec. \\
\hline $\begin{array}{l}30 \\
31\end{array}$ & $\begin{array}{l}3.00 \\
2.80 \\
2.50 \\
2.50 \\
2.40 \\
2.80 \\
2.90 \\
2.80 \\
2.80 \\
2.70 \\
3.40 \\
4.70 \\
4.40 \\
4.70 \\
4.90 \\
4.60 \\
3.70 \\
3.40 \\
3.90 \\
4.60 \\
4.80 \\
5.10 \\
4.20 \\
3.80 \\
3.70 \\
3.30 \\
3.20 \\
3.00 \\
3.00 \\
2.90 \\
2.90\end{array}$ & $\begin{array}{r}2.80 \\
2.60 \\
2.40 \\
3.00 \\
3.00 \\
4.60 \\
4.50 \\
4.20 \\
4.60 \\
7.30 \\
8.60 \\
12.20 \\
19.12 \\
19.50 \\
12.50 \\
5.40 \\
5.50 \\
4.70 \\
4.50 \\
4.60 \\
4.60 \\
4.70 \\
4.80 \\
4.80 \\
5.00 \\
4.60 \\
4.90\end{array}$ & $\begin{array}{l}5.90 \\
4.70 \\
4.60 \\
5.00 \\
4.80 \\
4.50 \\
4.20 \\
5.00 \\
8.10 \\
7.50 \\
6.30 \\
5.60 \\
4.70 \\
4.50 \\
4.30 \\
4.50 \\
4.30 \\
4.10 \\
5.00 \\
5.20 \\
5.20 \\
6.30 \\
6.20 \\
5.80 \\
6.10 \\
5.80 \\
5.40 \\
5.30 \\
5.10 \\
4.50\end{array}$ & $\begin{array}{l}4.10 \\
4.10 \\
4.05 \\
4.05 \\
4.00 \\
3.95 \\
3.90 \\
3.90 \\
3.85 \\
3.80 \\
4.90 \\
6.10 \\
6.70 \\
6.00 \\
5.50 \\
4.20 \\
4.00 \\
6.00 \\
7.70 \\
8.50 \\
7.40 \\
7.00 \\
7.50 \\
7.00 \\
9.20 \\
8.00 \\
6.00 \\
4.80 \\
4.50 \\
5.90\end{array}$ & $\begin{array}{l}4.90 \\
4.80 \\
4.60 \\
4.40 \\
4.30 \\
4.20 \\
4.00 \\
3.80 \\
3.80 \\
3.60 \\
3.50 \\
3.40 \\
3.40 \\
3.40 \\
3.30 \\
3.30 \\
3.20 \\
3.20 \\
3.70 \\
3.60 \\
3.50 \\
3.40 \\
3.40 \\
5.00 \\
4.40 \\
4.20 \\
4.00 \\
3.60 \\
3.50 \\
3.40 \\
3.40\end{array}$ & $\begin{array}{r}3.40 \\
3.30 \\
3.30 \\
3.60 \\
5.00 \\
4.80 \\
4.30 \\
5.10 \\
8.10 \\
8.50 \\
5.80 \\
4.60 \\
6.50 \\
3.90 \\
4.20 \\
6.40 \\
6.00 \\
7.00 \\
8.40 \\
6.00 \\
4.50 \\
3.80 \\
4.60 \\
16.40 \\
17.80 \\
14.60 \\
12.20 \\
8.40 \\
5.60 \\
6.70\end{array}$ & \begin{tabular}{|}
6.30 \\
9.40 \\
7.80 \\
7.00 \\
6.50 \\
6.20 \\
5.40 \\
5.00 \\
5.10 \\
4.20 \\
4.00 \\
3.60 \\
5440 \\
5.00 \\
4.80 \\
4.50 \\
4.30 \\
4.10 \\
4.00 \\
3.80 \\
3.60 \\
3.50 \\
3.80 \\
3.70 \\
3.60 \\
3.60 \\
4.00 \\
6.10 \\
6.70 \\
12.60 \\
9.20
\end{tabular} & $\begin{array}{l}6.40 \\
5.70 \\
5.00 \\
4.50 \\
4.00 \\
3.60 \\
3.40 \\
3.20 \\
3.10 \\
3.00 \\
2.90 \\
2.80 \\
3.40 \\
3.80 \\
3.00 \\
3.00 \\
2.90 \\
2.90 \\
2.80 \\
2.80 \\
2.80 \\
2.80 \\
2.90 \\
3.50 \\
3.80 \\
3.40 \\
3.20 \\
3.00 \\
2.90 \\
3.30 \\
3.90\end{array}$ & $\begin{array}{r}4.10 \\
6.10 \\
4.50 \\
3.20 \\
3.00 \\
2.90 \\
2.80 \\
2.70 \\
2.60 \\
2.50 \\
2.40 \\
2.30 \\
2.20 \\
2.30 \\
9.20 \\
12.60 \\
8.80 \\
8.00 \\
5.70 \\
4.30 \\
3.20 \\
3.00 \\
2.90 \\
2.80 \\
2.80 \\
2.70 \\
2.70 \\
2.70 \\
2.60 \\
2.60\end{array}$ & $\begin{array}{l}2.60 \\
2.50 \\
2.50 \\
2.60 \\
3.80 \\
4.00 \\
4.20 \\
3.770 \\
3.50 \\
3.40 \\
3.40 \\
3.60 \\
3.80 \\
3.70 \\
3.20 \\
3.00 \\
3.00 \\
2.90 \\
2.90 \\
2.80 \\
2.80 \\
3.00 \\
4.60 \\
5.00 \\
4.90 \\
3.40 \\
3.20 \\
3.00 \\
2.90 \\
2.80 \\
2.80\end{array}$ & $\begin{array}{l}2.80 \\
2.70 \\
4.60 \\
4.20 \\
4.30 \\
3.60 \\
3.40 \\
3.20 \\
3.10 \\
3.00 \\
3.00 \\
2.90 \\
2.90 \\
2.80 \\
2.80 \\
2.70 \\
2.70 \\
2.70 \\
2.70 \\
2.70 \\
2.60 \\
2.80 \\
2.90 \\
3.00 \\
3.20 \\
3.80 \\
4.50 \\
4.00 \\
5.00 \\
4.60\end{array}$ & $\begin{array}{l}3.70 \\
3.20 \\
3.10 \\
3.90 \\
4.50 \\
5.80 \\
5.90 \\
4.60 \\
3.90 \\
3.60 \\
3.30 \\
3.20 \\
3.10 \\
4.90 \\
4.20 \\
3.70 \\
3.50 \\
3.30 \\
3.00 \\
5.80 \\
6.50 \\
6.40 \\
6.00 \\
5.30 \\
4.80 \\
4.20 \\
4.10 \\
3.90 \\
3.60 \\
3.80 \\
7.20\end{array}$ \\
\hline
\end{tabular}

ETOWAH RIVER AT CANTON, GEORGIA.

This station was established by the United States Weather Bureau March 12, 1892. It is located on the iron highway bridge about 1,000 feet north of the Atlanta, Knoxville and Northern Railway station at Canton and about a half mile north of Canton Creek. The gage is a vertical timber attached to the upstream side of the left-bank pier of the bridge, and is graduated to feet and tenths. Owing to high water at the time the gage was put in it was set 1 foot higher than intended. Recognizing the error, the gage-height records were begun by adding 1 foot to the actual readings. It was the intention to lower the gage as soon as the water went down, but this has not been done, so that all of the gage heights and discharge measurements have been based on the rod with the zero point set 1 foot lower than the actual rod. The gage will probably be lowered to its proper place during the year 1901. This station is described in Water-Supply Paper No. 36, page 143. Records of measurements during 1899 will be found in the Twentyfirst Annual Report, Part IV, page 145. During 1900 the following measurements were made by B. M. Hall and his assistants:

February 27: Gage height, 0.80 foot; discharge, 1,113 second-feet.

May 19: Gage height, 1.05 feet; discharge, 1,351 second-feet.

December 1: Gage height, 0.55 foot; discharge, 816 second-feet. 
Daily gage height, in feet, of Etowah River at Canton, Georgia, for 1900.

\begin{tabular}{|c|c|c|c|c|c|c|c|c|c|c|c|c|}
\hline Day. & Jan. & Feb. & Mar. & Apr. & May. & June. & July. & Aug. & Sept. & Oct. & Nor. & Dec. \\
\hline & & & & & & & & & & & & \\
\hline 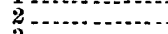 & .6 & .8 & & 0 & & & & 1. 0 & .6 & .2 & 1.4 & $\begin{array}{r}.0 \\
.6\end{array}$ \\
\hline $3 \ldots$ & 6 & 1.0 & .8 & .8 & 1.2 & 2.4 & 1.8 & 1.0 & .6 & .2 & 1.6 & .5 \\
\hline $\begin{array}{l}4 \\
5\end{array}$ & 6 & 1.0 & .8 & .8 & $\begin{array}{l}1.2 \\
1.1\end{array}$ & $\begin{array}{l}2.0 \\
3.0\end{array}$ & $\begin{array}{l}1.8 \\
1.8\end{array}$ & $\begin{array}{l}1.0 \\
1.0\end{array}$ & .6 & $\begin{array}{l}1.6 \\
1.5\end{array}$ & $\begin{array}{l}1.6 \\
1.4\end{array}$ & $\begin{array}{l}2.8 \\
2.6\end{array}$ \\
\hline 6 & 6 & 1. 2 & .8 & .8 & 1. 1 & $\begin{array}{l}0.0 \\
3.0\end{array}$ & $\begin{array}{l}2.0 \\
2.4\end{array}$ & .8 & .0 & 1.3 & 1.4 & 1.3 \\
\hline & 6 & 1.2 & .8 & .8 & 1.1 & 6.0 & 2.2 & .8 & .6 & 1.3 & 1.4 & 1.0 \\
\hline 9. & $\begin{array}{l}6 \\
6 \\
6\end{array}$ & 2.5 & $\begin{array}{l}3.4 \\
5.4\end{array}$ & .8 & $\begin{array}{l}1.1 \\
1.1\end{array}$ & $\begin{array}{l}6.6 \\
4.0\end{array}$ & $\begin{array}{l}1.8 \\
1.3\end{array}$ & .8 & .6 & $\begin{array}{l}2.2 \\
3.1\end{array}$ & $\begin{array}{l}1.4 \\
1.4\end{array}$ & .8 \\
\hline .. & 6 & 1.8 & 2.2 & .8 & 1.0 & (a) & 1.2 & .6 & .6 & 2.0 & 4 & .7 \\
\hline 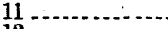 & 6 & 2.7 & 1.6 & .8 & 1.0 & (a) & 1.0 & .6 & .6 & 2.0 & 1.4 & .6 \\
\hline & 1.6 & 14.2 & 1.0 & 2.3 & 1.0 & (a) & 1.0 & .6 & .6 & 2.0 & 1.4 & .6 \\
\hline- & 1.0 & 6.0 & .9 & 2.6 & 1.0 & (a) & 0 & .6 & .6 & 6 & 1.4 & .5 \\
\hline $14 \ldots$ & .6 & 3.1 & .8 & 2.2 & 1.0 & (a) & 3.0 & .6 & .6 & 2.3 & 1.4 & .4 \\
\hline $\begin{array}{l}15-- \\
16=-\end{array}$ & $\begin{array}{l}6 \\
4 \\
\end{array}$ & $\begin{array}{l}2.0 \\
1.5\end{array}$ & .8 & $\begin{array}{l}2.0 \\
1.8\end{array}$ & $\begin{array}{r}9 \\
.9\end{array}$ & (a) & $\begin{array}{l}1.8 \\
1.2\end{array}$ & .8 & $\begin{array}{l}3.6 \\
5.0\end{array}$ & $\begin{array}{l}\text { 2.0 } \\
1.5\end{array}$ & $\begin{array}{l}1.2 \\
1.2\end{array}$ & .44 \\
\hline 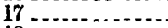 & 4 & 1.5 & .9 & 1.8 & .9 & (a) & 1.2 & 1.7 & 3.1 & 1.4 & 1.2 & .4 \\
\hline & & 1.0 & .9 & 2.3 & .9 & (a) & 1.2 & 2.3 & & 1.3 & 1.2 & .3 \\
\hline & 1.0 & 1.0 & .9 & 3.6 & 1.2 & (a) & 1.0 & 2.3 & 1.6 & 1.0 & 1.4 & .3 \\
\hline$\cdots$ & 1.0 & 1.0 & 5.2 & 2.0 & 1.1 & (a) & 1.0 & $\begin{array}{c}2.0 \\
1.0\end{array}$ & 1.4 & 1.0 & 2.1 & 2.3 \\
\hline & .4 & $\begin{array}{l}1.0 \\
1.0\end{array}$ & $\begin{array}{l}0.0 \\
1.8\end{array}$ & $\begin{array}{l}3.0 \\
3.0\end{array}$ & $\begin{array}{l}1.0 \\
1.0\end{array}$ & (a) & 1.0 & 1.0 & .77 & 1.0 & $\begin{array}{l}4.0 \\
3.7\end{array}$ & 1.3 \\
\hline$x$ & 4 & 1.0 & 1.8 & 2.0 & 1.0 & (a) & 1.0 & 1.0 & .6 & 2. & 3. 0 & 1.0 \\
\hline$\ldots$ & 4 & 1.0 & 2.8 & $\begin{array}{l}4.0 \\
9.0\end{array}$ & 1.8 & (a) & 1.0 & $\begin{array}{l}3.0 \\
2.0\end{array}$ & .6 & 7.2 & 2.1 & 1.0 \\
\hline & .4 & 1. 0 & 3.6 & 1.8 & $\begin{array}{l}1.4 \\
1.2\end{array}$ & (a) & $\begin{array}{l}1.0 \\
1.0\end{array}$ & $\begin{array}{l}1.0 \\
1.0\end{array}$ & .0 & $\begin{array}{l}0.3 \\
2.7\end{array}$ & $\begin{array}{l}4.0 \\
4.0\end{array}$ & .8 \\
\hline & 4 & .8 & 2.0 & 1.6 & 1.2 & (a) & 1.5 & .6 & .6 & 2.5 & 2.2 & .8 \\
\hline & 4 & .8 & 2.0 & 1.0 & 1.0 & (a) & 2.8 & .6 & .4 & 2. & 2.0 & .7 \\
\hline & 4 & & 1.9 & 1.4 & 1.0 & (a) & 4.0 & .6 & .3 & 1.4 & .7 & .7 \\
\hline & & & 1.9 & & 1.0 & & 2.0 & .6 & & 3 & & 3 \\
\hline
\end{tabular}

$a$ No record.

COOSAWATTEE RIVER AT CARTERS, GEORGIA.

This station was established August 15,1896, at the iron highway bridge at Carters, Murray County, Georgia, about 20 miles northeast of Calhoun. The gage was last verified November 17, 1900. The station is described in Water-Supply Paper No. 36, page 144. Records of measurements during 1899 will be found in the Twenty-first Annual Report, Part IV, page 146. During 1900 the following measurements were made by O. P. Hall and Max Hall:

April 28: Gage height, 2.60 feet; discharge, 1,075 second-feet.

May 11: Gage height, 2.15 feet; discharge, 811 second-feet.

May 24: Gage height, 2.05 feet; discharge, 781 second-feet.

August 13: Gage height, 1.58 feet; discharge, 576 second-feet.

September 7: Gage height, 1.25 feet; discharge, 423 second-feet.

November 17: Gage height, 1.37 feet; discharge, 458 second-feet.

November 26: Gage height, 4.08 feet; discharge, 1,899 second-feet.

December 22: Gage height, 2.70 feet; discharge, 1,132 second-feet. 
Daily gage height, in feet, of Coosawattee River at Carters, Georgia, for 1900.

\begin{tabular}{|c|c|c|c|c|c|c|c|c|c|c|}
\hline Day. & Jan. & Feb. & Mar. & Apr. & May. & June. & July. & Aug. & Nov. & Dec. \\
\hline $\begin{array}{r}1 \\
2 \\
3 \\
4\end{array}$ & $\begin{array}{l}1.20 \\
1.20 \\
1.10 \\
1.10 \\
1.00 \\
1.00 \\
1.10 \\
1.10 \\
1.20 \\
4.00 \\
4.30 \\
7.00 \\
. .50 \\
2.00 \\
1.90 \\
1.70 \\
1.70 \\
2.00 \\
4.30 \\
4.00 \\
2.50 \\
2.20 \\
2.00 \\
2.00 \\
1.90 \\
1.80 \\
1.80 \\
1.70 \\
1.60 \\
1.50 \\
1.50\end{array}$ & \begin{tabular}{r}
1.40 \\
1.40 \\
1.30 \\
1.40 \\
1.50 \\
1.70 \\
1.80 \\
2.00 \\
4.10 \\
2.50 \\
2.50 \\
8.50 \\
20.50 \\
5.40 \\
4.00 \\
3.20 \\
2.80 \\
2.70 \\
2.50 \\
2.20 \\
3.00 \\
3.20 \\
3.10 \\
3.05 \\
3.00 \\
3.00 \\
2.90 \\
2.50 \\
$\ldots \ldots .$. \\
\hdashline$\ldots . .$. \\
\\
.2.
\end{tabular} & $\begin{array}{l}3.00 \\
3.10 \\
2.70 \\
2.80 \\
4.75 \\
4.75 \\
4.90 \\
5.20 \\
5.00 \\
4.60 \\
3.10 \\
2.90 \\
3.00 \\
2.90 \\
2.80 \\
2.50 \\
2.50 \\
3.00 \\
7.50 \\
4.00 \\
3.50 \\
3.00 \\
2.90 \\
2.50 \\
2.00 \\
5.00 \\
3.60 \\
3.50 \\
3.10 \\
3.00 \\
2.80\end{array}$ & $\begin{array}{l}2.40 \\
2.40 \\
2.50 \\
2.60 \\
2.50 \\
2.60 \\
2.60 \\
2.50 \\
2.60 \\
2.70 \\
4.00 \\
5.00 \\
3.00 \\
2.50 \\
2.60 \\
2.70 \\
2.80 \\
3.00 \\
3.50 \\
3.70 \\
4.50 \\
3.50 \\
3.00 \\
2.90 \\
2.80 \\
2.70 \\
2.80 \\
3.00 \\
3.10 \\
3.00\end{array}$ & $\begin{array}{l}2.70 \\
2.60 \\
2.50 \\
2.40 \\
2.30 \\
2.20 \\
2.20 \\
2.10 \\
2.40 \\
2.20 \\
2.00 \\
1.90 \\
1.70 \\
1.70 \\
1.80 \\
1.80 \\
2.10 \\
2.00 \\
1.90 \\
1.80 \\
1.70 \\
1.70 \\
1.80 \\
1.90 \\
2.00 \\
2.10 \\
2.00 \\
1.90 \\
1.80 \\
1.80 \\
1.90\end{array}$ & $\begin{array}{l}1.90 \\
2.00 \\
2.00 \\
2.00 \\
2.10 \\
2.20 \\
5.00 \\
3.00 \\
5.00 \\
4.50 \\
3.00 \\
2.20 \\
2.00 \\
2.40 \\
2.60 \\
3.00 \\
3.00 \\
3.40 \\
5.00 \\
5.60 \\
4.20 \\
4.70 \\
4.50 \\
4.00 \\
\mathbf{5 . 0 0} \\
6.00 \\
6.50 \\
\mathbf{5 . 0 0} \\
4.50 \\
4.00\end{array}$ & $\begin{array}{l}3.50 \\
3.50 \\
5.00 \\
4.80 \\
4.00 \\
3.80 \\
3.60 \\
3.50 \\
3.40 \\
3.50 \\
3.40 \\
3.30 \\
3.00 \\
2.80 \\
2.60 \\
2.60 \\
2.40 \\
2.20 \\
2.00 \\
2.00 \\
2.00 \\
1.90 \\
1.80 \\
3.00 \\
2.20 \\
3.50 \\
5.20 \\
3.20 \\
2.40 \\
2.30 \\
2.20\end{array}$ & $\begin{array}{l}2.00 \\
2.00 \\
1.90 \\
1.90 \\
1.80 \\
1.70 \\
1.70 \\
1.70 \\
1.60 \\
1.60 \\
1.60 \\
1.60 \\
1.50 \\
1.50 \\
1.40 \\
1.40 \\
1.50 \\
1.50 \\
1.50 \\
1.60 \\
1.60 \\
1.80 \\
2.00 \\
2.50 \\
1.90 \\
(a) \\
(a) \\
(a) \\
(a) \\
(a) \\
(a)\end{array}$ & $\begin{array}{l}(a) \\
(a) \\
(a) \\
1.50 \\
1.40 \\
1.50 \\
1.50 \\
1.60 \\
1.60 \\
1.50 \\
1.50 \\
1.40 \\
1.40 \\
1.30 \\
1.30 \\
1.30 \\
1.40 \\
1.40 \\
1.40 \\
1.30 \\
1.30 \\
1.40 \\
1.40 \\
1.60 \\
3.50 \\
5.00 \\
4.00 \\
2.50 \\
1.50 \\
1.50\end{array}$ & $\begin{array}{l}1.40 \\
1.40 \\
1.50 \\
1.60 \\
1.80 \\
1.70 \\
1.60 \\
1.60 \\
1.60 \\
1.50 \\
1.40 \\
1.40 \\
1.50 \\
1.60 \\
1.70 \\
1.60 \\
1.80 \\
2.00 \\
4.00 \\
4.20 \\
3.20 \\
2.60 \\
2.70 \\
2.60 \\
2.50 \\
2.50 \\
2.40 \\
2.30 \\
2.40 \\
2.50 \\
2.60\end{array}$ \\
\hline
\end{tabular}

$a$ No record August 26 to November 3.

oOstaNAUla RIVER AT RESACA, GEORGIA.

This station was established July 27,1896 , on the iron bridge of the Western and Atlantic Railroad in the town of Resaca, Georgia, 1,000 feet from the railroad station. It is described in Water-Supply Paper No. 36, page 146. Records of measurements during 1899 will be found in the Twenty-first Annual Report, Part IV, page 147. During 1900 the following measurements were made by $O$. P. Hall:

April 30: Gage height, 8 feet; discharge, 5,118 second-feet.

May 15: Gage height, 3.60 feet; discharge, 1,466 second-feet.

May 25: Gage height, 3.75 feet; discharge, 1,539 second-feet.

December 11: Gage height, 4.30 feet; discharge, 1,919 second-feet. 
Daily gage height, in feet, of Oostanaula River at Resaca, Georgia, for 1900.

\begin{tabular}{|c|c|c|c|c|c|c|c|c|}
\hline Day. & Jan. & Feb. & Mar. & Apr. & May. & June. & Nov. & Dec. \\
\hline $\begin{array}{r}1 \\
2 \\
2\end{array}$ & $\begin{array}{r}2.7 \\
(a) \\
(a) \\
(a) \\
(a) \\
2.7 \\
2.6 \\
2.4 \\
2.5 \\
4.2 \\
11.3 \\
11.3 \\
9.9 \\
6.1 \\
4.9 \\
4.3 \\
4.1 \\
6.1 \\
13.1 \\
12.1 \\
10.2 \\
6.0 \\
5.2 \\
4.8 \\
4.4 \\
4.0 \\
3.7 \\
3.6 \\
3.5 \\
3.4\end{array}$ & 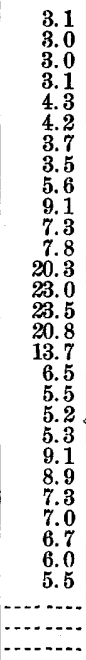 & $\begin{array}{r}6.0 \\
7.3 \\
6.8 \\
5.9 \\
5.4 \\
5.1 \\
6.9 \\
11.3 \\
15.5 \\
14.2 \\
11.1 \\
7.6 \\
6.7 \\
6.0 \\
5.6 \\
7.3 \\
6.9 \\
5.9 \\
6.0 \\
16.9 \\
17.2 \\
13.8 \\
8.8 \\
7.7 \\
8.0 \\
12.2 \\
10.8 \\
8.3 \\
7.2 \\
6.6 \\
6.2\end{array}$ & $\begin{array}{r}5.8 \\
5.4 \\
5.3 \\
5.6 \\
6.3 \\
6.0 \\
5.2 \\
5.0 \\
4.8 \\
4.6 \\
7.2 \\
11.6 \\
9.8 \\
7.4 \\
6.2 \\
5.8 \\
6.8 \\
11.9 \\
12.0 \\
10.4 \\
11.8 \\
11.6 \\
9.7 \\
7.7 \\
7.2 \\
6.2 \\
5.8 \\
5.6 \\
5.5 \\
7.8\end{array}$ & $\begin{array}{l}6.8 \\
5.7 \\
5.5 \\
5.3 \\
4.8 \\
4.6 \\
4.4 \\
4.0 \\
3.9 \\
3.8 \\
3.7 \\
3.6 \\
3.6 \\
3.4 \\
3.4 \\
3.4 \\
3.3 \\
3.3 \\
3.8 \\
3.9 \\
3.8 \\
3.7 \\
3.6 \\
3.7 \\
3.8 \\
4.0 \\
4.0 \\
3.7 \\
3.6 \\
3.6 \\
3.4\end{array}$ & $\begin{array}{r}3.3 \\
3.5 \\
4.0 \\
5.5 \\
5.0 \\
7.7 \\
7.9 \\
13.0 \\
10.8 \\
7.5 \\
5.6 \\
5.8 \\
6.8 \\
6.6 \\
5.6 \\
4.8 \\
6.6 \\
6.8 \\
10.9 \\
7.0 \\
6.5 \\
4.8 \\
9.9 \\
12.8 \\
14.0 \\
15.0 \\
17.2 \\
17.5 \\
13.0 \\
9.6\end{array}$ & $\begin{array}{r}2.8 \\
2.9 \\
3.0 \\
4.6 \\
4.5 \\
3.7 \\
3.5 \\
3.0 \\
2.9 \\
2.8 \\
2.8 \\
2.8 \\
2.7 \\
2.7 \\
2.7 \\
2.7 \\
2.6 \\
2.6 \\
2.6 \\
2.7 \\
2.8 \\
3.6 \\
3.4 \\
3.3 \\
3.7 \\
14.4 \\
13.0 \\
12.2 \\
7.6 \\
5.2\end{array}$ & $\begin{array}{r}4.5 \\
4.2 \\
4.0 \\
6.0 \\
8.6 \\
8.3 \\
6.0 \\
5.6 \\
5.0 \\
4.8 \\
4.2 \\
4.0 \\
4.0 \\
1.0 \\
4.0 \\
3.9 \\
3.5 \\
3.4 \\
3.4 \\
3.8 \\
10.9 \\
9.3 \\
6.8 \\
9.0 \\
8.7 \\
6.7 \\
5.6 \\
4.6 \\
5.4 \\
5.2 \\
7.7\end{array}$ \\
\hline
\end{tabular}

a Frozen.

NôTE.-This is a half-year Weather Bureau station.

COOSA RIVER AT ROME, GEORGIA.

This station is described in Water-Supply Paper No. 36, page 148. Measurements of flow are made at Rome, also at Riverside, 120 miles farther downstream. The measurements at Rome are made on the Oostanaula and the Etowah just above their junction to form the Coosa. Etowah River is measured at the Second avenue bridge, and Oostanaula River at the Fifth avenue bridge, and the results added together give the flow of Coosa River at Rome. Results of measurements during 1899 will be found in the Twenty-first Annual Report, Part IV, page 149. During 1900 the following measurements were made by Max Hall and others:

February 21: Gage height, 4.80 feet; discharge, 8,115 second-feet.

May 19: Gage height, 2.30 feet; discharge, 4,496 second-feet.

September 13: Gage height, 0.90 foot; discharge, 1,992 second-feet.

December 8: Gage height, 3.73 feet; discharge, 6,066 second-feet. 
OPERATIONS AT RIVER STATIONS, 1900.-PART II. [No. 48.

Daily gage height, in feet, of Coosa River at Rome, Georgia, for 1900.

\begin{tabular}{|c|c|c|c|c|c|c|c|c|c|c|c|c|}
\hline Day. & Jan. & Feb. & Mar. & Apr. & May. & June. & July. & Aug. & Sept. & Oct. & Nov. & Dec. \\
\hline $\begin{array}{r}1 \\
2 \\
3 \\
4 \\
5\end{array} 6$ & $\begin{array}{r}2.0 \\
1.6 \\
1.5 \\
1.5 \\
1.5 \\
1.5 \\
1.5 \\
1.5 \\
1.5 \\
1.5 \\
2.0 \\
7.0 \\
9.0 \\
7.2 \\
5.5 \\
3.5 \\
3.0 \\
2.9 \\
5.0 \\
1.3 \\
10.6 \\
8.5 \\
5.8 \\
4.0 \\
3.4 \\
3.1 \\
2.8 \\
2.6 \\
2.4 \\
2.1 \\
2.0\end{array}$ & $\begin{array}{r}2.0 \\
1.8 \\
1.6 \\
2.0 \\
3.0 \\
3.8 \\
2.8 \\
2.4 \\
4.0 \\
6.9 \\
7.0 \\
6.4 \\
22.6 \\
27.2 \\
25.3 \\
21.2 \\
18.0 \\
10.7 \\
5.0 \\
4.0 \\
4.1 \\
6.8 \\
7.6 \\
6.0 \\
5.8 \\
5.2 \\
4.6 \\
4.0 \\
\cdots \ldots . . \\
\hdashline \cdots . . \\
\hdashline \cdots\end{array}$ & $\begin{array}{r}4.2 \\
5.8 \\
5.6 \\
4.4 \\
4.1 \\
3.8 \\
5.0 \\
8.2 \\
15.0 \\
13.4 \\
10.3 \\
7.5 \\
5.5 \\
4.8 \\
4.2 \\
5.3 \\
5.6 \\
4.5 \\
5.2 \\
15.9 \\
17.5 \\
14.6 \\
10.4 \\
7.2 \\
8.8 \\
13.0 \\
12.1 \\
8.9 \\
5.8 \\
5.7 \\
5.3\end{array}$ & $\begin{array}{r}4.4 \\
4.2 \\
4.0 \\
4.0 \\
4.0 \\
4.0 \\
3.8 \\
3.8 \\
3.6 \\
3.5 \\
6.0 \\
11.0 \\
7.4 \\
5.5 \\
4.5 \\
5.6 \\
6.2 \\
11.0 \\
11.1 \\
11.4 \\
13.6 \\
12.7 \\
10.5 \\
8.6 \\
8.5 \\
6.5 \\
5.3 \\
4.8 \\
4.3 \\
6.0 \\
\cdots . . . .\end{array}$ & $\begin{array}{l}6.2 \\
4.8 \\
4.0 \\
4.0 \\
3.8 \\
3.7 \\
3.6 \\
3.4 \\
3.0 \\
3.0 \\
3.0 \\
3.0 \\
2.5 \\
2.4 \\
2.4 \\
2.4 \\
2.4 \\
2.4 \\
2.9 \\
3.0 \\
2.6 \\
2.5 \\
2.3 \\
2.9 \\
3.2 \\
2.7 \\
2.6 \\
2.5 \\
2.4 \\
2.9 \\
3.0\end{array}$ & $\begin{array}{r}2.4 \\
2.5 \\
2.8 \\
4.2 \\
4.2 \\
4.2 \\
4.8 \\
13.0 \\
12.6 \\
8.0 \\
5.9 \\
5.0 \\
5.2 \\
5.3 \\
4.2 \\
3.8 \\
4.8 \\
6.0 \\
6.5 \\
7.2 \\
4.2 \\
3.6 \\
5.5 \\
14.2 \\
18.2 \\
17.0 \\
15.5 \\
15.6 \\
14.2 \\
10.0 \\
\cdots . . .\end{array}$ & $\begin{array}{r}10.5 \\
8.0 \\
8.0 \\
7.0 \\
5.5 \\
4.2 \\
3.8 \\
3.8 \\
4.0 \\
4.3 \\
3.8 \\
3.4 \\
3.8 \\
3.4 \\
3.4 \\
3.3 \\
3.1 \\
3.0 \\
2.8 \\
2.6 \\
2.5 \\
2.4 \\
2.4 \\
2.4 \\
3.6 \\
2.8 \\
6.2 \\
6.8 \\
6.2 \\
4.5 \\
4.0\end{array}$ & $\begin{array}{l}3.4 \\
3.2 \\
3.0 \\
2.8 \\
2.6 \\
2.5 \\
2.2 \\
2.2 \\
2.0 \\
2.0 \\
1.8 \\
1.8 \\
1.8 \\
1.7 \\
2.0 \\
1.7 \\
1.6 \\
1.8 \\
2.2 \\
2.0 \\
1.6 \\
1.6 \\
1.6 \\
1.9 \\
2.4 \\
2.0 \\
1.8 \\
1.6 \\
1.5 \\
1.5 \\
1.5\end{array}$ & $\begin{array}{r}1.5 \\
1.5 \\
1.7 \\
1.7 \\
1.5 \\
1.5 \\
1.4 \\
1.0 \\
1.0 \\
.8 \\
.8 \\
.8 \\
.8 \\
.8 \\
6.5 \\
11.1 \\
7.0 \\
3.2 \\
2.3 \\
2.0 \\
1.8 \\
1.8 \\
1.6 \\
1.6 \\
1.5 \\
1.5 \\
1.4 \\
1.4 \\
1.3 \\
1.3 \\
\hdashline . .5\end{array}$ & $\begin{array}{r}1.2 \\
1.2 \\
1.0 \\
1.0 \\
.9 \\
.9 \\
.9 \\
3.8 \\
5.9 \\
2.6 \\
2.0 \\
1.8 \\
2.5 \\
3.2 \\
3.0 \\
2.0 \\
1.6 \\
1.5 \\
1.5 \\
1.4 \\
1.8 \\
1.8 \\
1.6 \\
1.6 \\
1.5 \\
1.5 \\
1.4 \\
2.2 \\
2.2 \\
2.1 \\
2.1\end{array}$ & $\begin{array}{r}2.1 \\
2.2 \\
2.0 \\
2.3 \\
2.3 \\
2.1 \\
2.1 \\
2.0 \\
1.9 \\
1.8 \\
1.8 \\
1.6 \\
1.5 \\
1.5 \\
1.5 \\
1.5 \\
1.5 \\
1.4 \\
1.4 \\
1.6 \\
1.8 \\
2.1 \\
2.1 \\
2.0 \\
5.0 \\
11.0 \\
11.5 \\
8.6 \\
7.0 \\
4.0\end{array}$ & $\begin{array}{l}3.2 \\
2.8 \\
2.6 \\
3.5 \\
7.4 \\
6.8 \\
5.2 \\
3.8 \\
3.6 \\
3.2 \\
2.8 \\
2.6 \\
2.6 \\
2.4 \\
2.2 \\
2.2 \\
2.2 \\
2.0 \\
2.0 \\
2.8 \\
6.7 \\
8.0 \\
7.0 \\
6.6 \\
6.6 \\
5.6 \\
4.0 \\
3.8 \\
3.6 \\
3.5 \\
5.6\end{array}$ \\
\hline
\end{tabular}

COOSA RIVER NEAR RIVERSIDE, ALABẠMA.

This station, established September 25,1896 , is at the bridge of the Southern Railway near Riverside. It is described in Water-Supply Paper No. 36, page 149. Records of measurements during 1899 will be found in the Twenty-first Annual Report, Part IV, page 150. During 1900 the following measurements were made by Max Hall and others :

February 10: Gage height, 5.03 feet; discharge, 13,493 second-feet.

March 21: Gage height, 12.50 feet; discharge, 43,759 second-feet.

May 5: Gage height, 4.15 feet; discharge, 11,196 second-feet.

August 21: Gage height, 2.32 feet; discharge, 5,609 second-feet.

December 28: Gage height, 4.25 feet; discharge, 11,335 second-feet. 
Daily gage height, in feet, of Coosa River near Riverside, Alabama, for 1900.

\begin{tabular}{|c|c|c|c|c|c|c|c|c|c|c|c|c|}
\hline Da & Jan. & Feb. & Mar. & Apr. & May. & June. & July. & Aug. & Sept. & Oct. & Nov. & Dec. \\
\hline $\begin{array}{r}1 \\
\mathbf{2} \\
\mathbf{3} \\
\mathbf{4} \\
\mathbf{5} \\
\mathbf{6} \\
\mathbf{7} \\
\mathbf{8} \\
\mathbf{9} \\
\mathbf{1 0}\end{array}$ & $\begin{array}{r}3.50 \\
3.00 \\
2.50 \\
2.40 \\
2.15 \\
2.05 \\
1.95 \\
1.95 \\
\mathbf{2 . 0 0} \\
2.00 \\
2.10 \\
3.50 \\
6.00 \\
7.40 \\
7.00 \\
6.40 \\
5.10 \\
4.00 \\
4.25 \\
8.00 \\
9.70 \\
10.00 \\
9.40 \\
8.75 \\
7.75 \\
6.00 \\
4.10 \\
3.60 \\
3.30 \\
3.00 \\
2.70\end{array}$ & $\begin{array}{r}2.70 \\
2.65 \\
2.60 \\
2.50 \\
2.60 \\
2.80 \\
2.95 \\
3.00 \\
3.75 \\
4.25 \\
5.80 \\
6.50 \\
13.30 \\
15.30 \\
15.20 \\
14.50 \\
14.00 \\
13.25 \\
12.80 \\
12.10 \\
9.00 \\
7.80 \\
6.80 \\
7.20 \\
6.90 \\
6.50 \\
5.25 \\
5.00\end{array}$ & $\begin{array}{r}6.90 \\
7.55 \\
6.90 \\
6.25 \\
5.40 \\
5.00 \\
4.90 \\
6.00 \\
8.75 \\
10.00 \\
10.55 \\
10.05 \\
8.75 \\
7.50 \\
5.60 \\
6.00 \\
6.30 \\
6.00 \\
6.50 \\
10.00 \\
12.20 \\
12.85 \\
12.60 \\
11.80 \\
10.60 \\
10.30 \\
10.20 \\
9.85 \\
9.50 \\
8.50 \\
7.20\end{array}$ & $\begin{array}{r}6.65 \\
6.25 \\
6.00 \\
5.60 \\
5.10 \\
4.90 \\
4.75 \\
4.40 \\
4.35 \\
4.30 \\
6.50 \\
12.40 \\
12.90 \\
11.70 \\
9.50 \\
7.20 \\
12.40 \\
18.10 \\
17.55 \\
15.65 \\
13.95 \\
13.15 \\
12.65 \\
12.20 \\
10.80 \\
9.15 \\
7.90 \\
6.50 \\
5.70 \\
5.35\end{array}$ & $\begin{array}{l}5.00 \\
5.30 \\
5.30 \\
4.75 \\
4.30 \\
4.20 \\
4.00 \\
3.65 \\
3.40 \\
3.30 \\
3.15 \\
.95 \\
2.70 \\
2.70 \\
2.65 \\
2.65 \\
2.60 \\
2.60 \\
2.60 \\
2.60 \\
2.65 \\
3.20 \\
2.90 \\
3.00 \\
3.25 \\
3.10 \\
3.20 \\
3.00 \\
2.80 \\
2.70 \\
2.60\end{array}$ & $\begin{array}{r}2.75 \\
2.80 \\
2.90 \\
2.60 \\
2.70 \\
3.45 \\
3.90 \\
4.20 \\
7.05 \\
8.30 \\
8.00 \\
7.70 \\
6.70 \\
4.30 \\
4.50 \\
4.70 \\
5.00 \\
4.90 \\
6.90 \\
6.90 \\
6.45 \\
6.10 \\
7.00 \\
11.35 \\
12.50 \\
14.10 \\
14.42 \\
14.60 \\
13.80 \\
12.80\end{array}$ & $\begin{array}{r}11.60 \\
10.10 \\
8.90 \\
8.20 \\
7.50 \\
6.45 \\
5.50 \\
4.70 \\
5.00 \\
4.30 \\
4.20 \\
4.10 \\
5.65 \\
4.65 \\
3.75 \\
3.60 \\
3.50 \\
3.35 \\
3.10 \\
3.00 \\
2.90 \\
2.70 \\
2.45\end{array}$ & $\begin{array}{l}4.70 \\
3.90 \\
3.00 \\
2.75 \\
2.55 \\
2.40 \\
2.25 \\
2.15 \\
2.10 \\
2.00 \\
2.00 \\
1.90 \\
2.25 \\
2.00 \\
1.90 \\
1.85 \\
2.00 \\
2.60 \\
2.20 \\
2.10 \\
2.20 \\
2.00 \\
2.00 \\
1.95 \\
1.90 \\
2.20 \\
2.10 \\
2.00 \\
1.95 \\
1.90 \\
1.90\end{array}$ & $\begin{array}{l}1.85 \\
2.00 \\
2.20 \\
2.10 \\
2.00 \\
1.80 \\
1.70 \\
1.60 \\
1.50 \\
1.45 \\
1.35 \\
1.30 \\
1.25 \\
1.20 \\
3.35 \\
6.00 \\
7.00 \\
7.50 \\
6.00 \\
4.35 \\
3.20 \\
2.50 \\
2.00 \\
1.90 \\
1.85 \\
1.80 \\
1.80 \\
1.65 \\
1.60 \\
1.55\end{array}$ & $\begin{array}{l}1.55 \\
1.55 \\
1.50 \\
1.50 \\
1.50 \\
1.45 \\
1.40 \\
1.50 \\
2.20 \\
2.35 \\
3.85 \\
3.60 \\
3.80 \\
3.80 \\
3.00 \\
2.90 \\
2.80 \\
2.65 \\
2.50 \\
2.40 \\
2.30 \\
2.20 \\
2.15 \\
3.00 \\
5.25 \\
7.50 \\
5.00 \\
3.80 \\
3.00 \\
2.65 \\
2.50\end{array}$ & $\begin{array}{l}2.30 \\
2.25 \\
2.50 \\
2.50 \\
2.50 \\
2.40 \\
2.40 \\
2.35 \\
2.30 \\
2.30 \\
2.15 \\
2.10 \\
2.10 \\
2.00 \\
1.90 \\
1.80 \\
1.75 \\
1.70 \\
1.80 \\
2.00 \\
2.50 \\
4.00 \\
3.80 \\
3.20 \\
3.10 \\
3.00 \\
4.35 \\
6.40 \\
9.20 \\
8.20\end{array}$ & $\begin{array}{l}5.75 \\
4.35 \\
3.75 \\
3.40 \\
3.30 \\
4.35 \\
6.05 \\
5.40 \\
4.80 \\
4.00 \\
3.60 \\
3.15 \\
2.95 \\
2.80 \\
2.70 \\
2.65 \\
2.60 \\
2.55 \\
2.55 \\
3.00 \\
3.30 \\
5.20 \\
7.00 \\
7.30 \\
6.90 \\
6.35 \\
5.90 \\
4.90 \\
4.30 \\
4.00 \\
6.50\end{array}$ \\
\hline
\end{tabular}

COOSA RIVER AT LOCKS NOS. 4 AND 5, ALABAMA.

Records of gage heights at these stations are kept by the United States Engineer Corps, who have kindly furnished copies to the Geological Survey. Records of gage heights at Lock No. 5 during the year 1900 are not available. The records for Lock No. 4 are given in the accompanying table. Discharge measurements are not made at either of these stations. The stations are described in Water-Supply Paper No. 36, page 150.

IRR $48-01-5$ 
OPERATIONS AT RIVER STATIONS, 1900.-PART II. [No. 48.

Daily gage height, in feet, of Coosa River at Lock No. 4, Alabama, for 1900.

\begin{tabular}{|c|c|c|c|c|c|c|c|c|c|c|c|c|}
\hline Day. & Jan. & Feb: & Mar. & Apr. & May. & June. & Jaly. & Aug. & Sept. & Oct. & Nov. & Dec. \\
\hline $\begin{array}{r}1 \\
2 \\
2\end{array} 30$. & $\begin{array}{r}3.5 \\
3.0 \\
2.7 \\
2.4 \\
2.1 \\
1.9 \\
1.9 \\
2.0 \\
2.0 \\
1.9 \\
2.1 \\
5.8 \\
7.0 \\
8.6 \\
7.6 \\
7.6 \\
6.2 \\
5.1 \\
4.6 \\
7.9 \\
10.5 \\
11.5 \\
11.0 \\
8.9 \\
7.0 \\
5.5 \\
4.5 \\
4.0 \\
3.8 \\
3.3 \\
3.0\end{array}$ & \begin{tabular}{r}
2.9 \\
2.7 \\
2.5 \\
2.5 \\
2.9 \\
3.2 \\
3.6 \\
3.9 \\
4.5 \\
5.9 \\
6.7 \\
7.5 \\
15.0 \\
17.5 \\
17.4 \\
17.0 \\
16.5 \\
16.1 \\
15.5 \\
13.7 \\
10.3 \\
8.6 \\
8.3 \\
8.4 \\
8.3 \\
7.5 \\
6.8 \\
6.2 \\
$\cdots \ldots .$. \\
\hdashline$\ldots .$. \\
$\cdots \ldots . .$.
\end{tabular} & $\begin{array}{r}7.9 \\
8.4 \\
7.9 \\
7.4 \\
6.5 \\
6.0 \\
6.0 \\
7.8 \\
10.0 \\
11.2 \\
11.9 \\
11.6 \\
10.3 \\
8.6 \\
6.8 \\
6.8 \\
7.2 \\
7.0 \\
7.1 \\
11.2 \\
13.8 \\
14.7 \\
14.3 \\
13.5 \\
12.0 \\
11.6 \\
11.6 \\
11.8 \\
11.0 \\
9.9 \\
8.0\end{array}$ & $\begin{array}{r}6.9 \\
6.1 \\
5.5 \\
5.3 \\
5.3 \\
5.4 \\
5.1 \\
4.9 \\
4.6 \\
4.9 \\
7.4 \\
13.9 \\
14.5 \\
13.0 \\
10.8 \\
9.0 \\
14.6 \\
20.3 \\
20.3 \\
18.0 \\
16.0 \\
15.0 \\
14.4 \\
13.8 \\
12.2 \\
10.2 \\
9.2 \\
7.8 \\
6.8 \\
6.0\end{array}$ & $\begin{array}{l}5.8 \\
6.0 \\
6.2 \\
5.4 \\
4.8 \\
4.7 \\
4.2 \\
4.0 \\
3.7 \\
3.7 \\
3.5 \\
3.4 \\
3.3 \\
3.1 \\
3.0 \\
2.9 \\
2.8 \\
2.8 \\
2.8 \\
2.9 \\
3.1 \\
3.2 \\
3.0 \\
3.4 \\
3.6 \\
3.3 \\
3.5 \\
3.0 \\
3.0 \\
2.8 \\
2.8\end{array}$ & $\begin{array}{r}3.0 \\
3.2 \\
3.2 \\
2.8 \\
3.2 \\
3.8 \\
4.4 \\
5.0 \\
7.0 \\
9.0 \\
9.1 \\
8.0 \\
6.0 \\
5.0 \\
5.0 \\
5.3 \\
5.7 \\
5.5 \\
7.6 \\
7.9 \\
7.3 \\
6.7 \\
6.7 \\
12.1 \\
14.2 \\
16.6 \\
15.5 \\
17.0 \\
15.2 \\
14.5 \\
\ldots \ldots . .\end{array}$ & $\begin{array}{r}13.6 \\
11.0 \\
10.0 \\
9.4 \\
8.4 \\
7.3 \\
6.1 \\
5.1 \\
5.4 \\
4.7 \\
4.9 \\
4.4 \\
4.8 \\
3.3 \\
3.3 \\
3.7 \\
3.7 \\
3.5 \\
3.1 \\
2.9 \\
2.9 \\
2.7 \\
2.7 \\
2.7 \\
2.8 \\
2.7 \\
4.0 \\
4.2 \\
5.6 \\
6.3 \\
6.8\end{array}$ & $\begin{array}{l}5.7 \\
4.4 \\
3.6 \\
3.2 \\
2.8 \\
2.5 \\
2.2 \\
2.2 \\
2.1 \\
2.0 \\
2.0 \\
1.9 \\
2.2 \\
2.0 \\
1.9 \\
1.8 \\
2.1 \\
1.9 \\
2.0 \\
2.2 \\
2.4 \\
2.3 \\
2.0 \\
1.8 \\
1.9 \\
2.3 \\
2.4 \\
2.3 \\
1.9 \\
2.0 \\
1.9\end{array}$ & $\begin{array}{l}1.8 \\
1.9 \\
2.3 \\
2.1 \\
1.9 \\
1.8 \\
1.6 \\
1.6 \\
1.8 \\
1.2 \\
1.2 \\
1.1 \\
1.1 \\
1.2 \\
4.3 \\
6.4 \\
8.6 \\
8.7 \\
6.4 \\
4.4 \\
3.0 \\
2.4 \\
2.1 \\
1.9 \\
1.8 \\
1.7 \\
1.7 \\
1.6 \\
1.5 \\
1.5\end{array}$ & $\begin{array}{l}1.3 \\
1.2 \\
1.2 \\
1.2 \\
1.2 \\
1.2 \\
1.3 \\
2.0 \\
2.4 \\
3.9 \\
4.7 \\
4.2 \\
4.4 \\
4.4 \\
3.7 \\
3.3 \\
3.2 \\
2.7 \\
2.1 \\
1.9 \\
1.7 \\
1.6 \\
2.3 \\
3.5 \\
5.0 \\
8.6 \\
8.2 \\
5.2 \\
4.5 \\
2.9 \\
2.6\end{array}$ & $\begin{array}{r}2.6 \\
2.4 \\
2.4 \\
2.7 \\
2.7 \\
2.7 \\
2.8 \\
2.9 \\
2.5 \\
2.3 \\
2.0 \\
1.9 \\
1.8 \\
1.7 \\
1.7 \\
1.7 \\
1.6 \\
1.6 \\
1.5 \\
2.1 \\
2.3 \\
4.5 \\
4.4 \\
4.0 \\
3.6 \\
6.1 \\
9.0 \\
10.2 \\
10.0 \\
8.7 \\
\ldots \ldots . . .\end{array}$ & $\begin{array}{l}7.7 \\
5.3 \\
4.2 \\
3.9 \\
4.7 \\
5.7 \\
7.0 \\
6.8 \\
5.7 \\
4.8 \\
4.2 \\
3.8 \\
3.5 \\
3.3 \\
3.2 \\
3.0 \\
2.9 \\
2.8 \\
2.6 \\
2.8 \\
3.5 \\
5.5 \\
7.4 \\
8.5 \\
8.1 \\
8.5 \\
6.9 \\
6.0 \\
5.1 \\
4.5 \\
6.0\end{array}$ \\
\hline
\end{tabular}

TALLAPOOSA RIVER NEAR SUSANNA, ALABAMA.

This station was established July 27,1900 , by J. R. Hall. It is located at the mouth of Blue Creek, which is 10 feet above the east landing of McCarty's ferry, 13 miles southwest of Dadeville, and 3 miles from Susanna, the nearest post-office. The rod is graduated to feet and tenths; it is 18 feet long, and is nailed vertically to a tree overhanging the water on the south side of the creek at the junction of the creek and the river. The gage is referred to a bench mark on a white hickory tree about 40 feet from the rod on the south bank of the creek, and is 376.67 feet above tide water. Discharge measurements are made from a boat held in place by a wire stretched across the river, upon which the distances from the initial point are tagged. The section is an exceptionally good one, depth and current being almost uniform the entire width of the stream. The observer is T. A. Walls, a farmer who lives 1 mile from the station. During 1990 the following measurements were made by James R. Hall:

July 27: Gage height, 1.80 feet; discharge, 2,309 second-feet.

August 9: Gage height, 1.55 feet; discharge, 1,900 second-feet.

September 28: Gage height, 1.50 feet; discharge, 1,809 second-feet.

November 24: Gage height, 2.40 feet; discharge, 3,629 second-teet. 
Daily gage height, in feet, of Tallapoosa River near Susanna, Alabama; for 1900.

\begin{tabular}{|c|c|c|c|c|c|c|c|c|c|c|c|c|c|}
\hline Day. & July. & Aug. & Sept. & Oct. & Nov. & Dec. & Day. & Jüly. & Aug. & Sept. & Oct. & Nov. & Dec. \\
\hline $\begin{array}{r}8 \\
9 \\
10 \\
11 \\
12 \\
13 \\
14 \\
16 \\
16\end{array}$ & 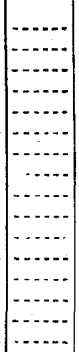 & \begin{tabular}{|}
5.80 \\
4.00 \\
2.00 \\
1.80 \\
1.80 \\
2.10 \\
2.20 \\
1.70 \\
1.55 \\
1.50 \\
1.40 \\
1.40 \\
1.40 \\
1.40 \\
1.90
\end{tabular} & \begin{tabular}{|l|}
2.40 \\
3.80 \\
4.80 \\
4.20 \\
2.25 \\
1.50 \\
1.45 \\
1.45 \\
1.40 \\
1.35 \\
1.35 \\
1.35 \\
1.35 \\
1.30 \\
1.35 \\
11.70
\end{tabular} & $\begin{array}{l}1.40 \\
1.40 \\
1.40 \\
1.35 \\
1.30 \\
2.80 \\
3.00 \\
2.50 \\
1.85 \\
1.80 \\
1.75 \\
1.70 \\
1.90 \\
2.40 \\
2.45 \\
2.40\end{array}$ & $\begin{array}{l}1.80 \\
1.70 \\
1.70 \\
1.65 \\
1.65 \\
1.65 \\
1.60 \\
1.60 \\
1.60 \\
1.60 \\
1.60 \\
1.55 \\
1.55 \\
1.60 \\
1.60 \\
1.60\end{array}$ & $\begin{array}{l}2.00 \\
2.00 \\
2.10 \\
2.20 \\
2.30 \\
2.50 \\
2.40 \\
2.40 \\
2.40 \\
2.30 \\
2.10 \\
2.00 \\
1.90 \\
3.80 \\
3.90 \\
2.80\end{array}$ & \begin{tabular}{|l}
$17 \ldots \ldots$ \\
$18 \ldots \ldots$ \\
$19 \ldots \ldots$ \\
$20 \ldots \ldots$ \\
$21 \ldots \ldots$ \\
$22 \ldots$ \\
$23 \ldots \ldots$ \\
$24 \ldots \ldots$ \\
$25 \ldots \ldots$ \\
$26 \ldots \ldots$ \\
$27 \ldots \ldots$ \\
$28 \ldots \ldots$ \\
$29 \ldots \ldots$ \\
$31 \ldots \ldots$ \\
$31 \ldots \ldots$ \\
\end{tabular} & \begin{tabular}{|c|}
$\ldots \ldots$ \\
\\
\hdashline \\
\\
\hdashline$\ldots . \cdots$ \\
1.80 \\
1.90 \\
1.80 \\
4.00 \\
6.80 \\
\end{tabular} & $\begin{array}{l}1.95 \\
1.95 \\
1.80 \\
1.75 \\
1.70 \\
1.70 \\
1.90 \\
2.00 \\
2.05 \\
2.50 \\
2.15 \\
2.00 \\
1.90 \\
1.80 \\
2.25\end{array}$ & $\begin{array}{l}8.40 \\
4.80 \\
3.00 \\
2.50 \\
1.80 \\
1.30 \\
1.80 \\
1.70 \\
1.60 \\
1.50 \\
1.50 \\
1.50 \\
1.45 \\
1.45\end{array}$ & \begin{tabular}{|l}
2.35 \\
2.30 \\
2.20 \\
2.10 \\
1.90 \\
1.70 \\
3.90 \\
6.00 \\
5.00 \\
4.30 \\
4.10 \\
2.30 \\
2.20 \\
1.90 \\
1.85
\end{tabular} & $\begin{array}{l}1.75 \\
1.75 \\
1.80 \\
1.85 \\
1.85 \\
1.90 \\
2.40 \\
2.40 \\
3.00 \\
4.90 \\
4.20 \\
3.90 \\
3.00 \\
2.80\end{array}$ & $\begin{array}{l}2.60 \\
2.50 \\
2.40 \\
4.50 \\
5.80 \\
4.50 \\
4.00 \\
4.00 \\
3.70 \\
3.20 \\
2.80 \\
2.70 \\
2.60 \\
2.70 \\
2.90\end{array}$ \\
\hline
\end{tabular}

TALLAPOOSA RIVER NEAR STURDEVANT, ALABAMA.

This station was established July 19, 1900, by J. R. Hall. It is located at the Columbus and Western Railroad bridge a fourth of a mile west of Sturdevant. The gage rod is 20 feet high, and is graduated to feet and tenths. It is in two sections and is fastened vertically, the shorter section to a post at the edge of the water on the east bank about 20 feet below the bridge, and the longer section to the first stone pier from the east bank. It is so set that when the water rises above the short section it is on the long section, and the readings are made as from one continuous rod. The initial point of sounding is the east end of the bridge. The section is broken by three piers and by some large rocks below the bridge. The gage is referred to a bench mark consisting of a nail in the southwest corner of pier No. 2 , east side of river, 455.70 feet above tide water and 14.20 feet above the zero of the gage. The observer is B. F. Neighbors, farmer and postmaster at Sturdevant, who lives a fourth of a mile from the station. During 1900 the following measurements were made by James R. Hall:

July 20: Gage height, 2.85 feet; discharge, 2,603 second-feet.

August 13: Gage height, 1.95 feet; discharge, 1,887 secónd-feet.

Daily gage height, in feet, of Tallapoosa River near Sturdevant, Alabama, for 1900.

\begin{tabular}{|c|c|c|c|c|c|c|c|c|c|c|c|c|c|}
\hline Day. & July. & Aug. & Sept. & Oct. & Nov. & Dec. & Day. & July. & Aug. & Sept. & Oct. & Nov. & Dec. \\
\hline 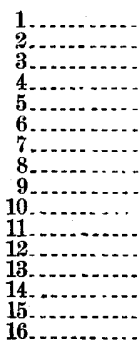 & & $\begin{array}{l}4.30 \\
3.40 \\
2.80 \\
2.50 \\
2.40 \\
2.35 \\
2.25 \\
2.20 \\
2.10 \\
2.00 \\
1.95 \\
1.90 \\
2.00 \\
2.10 \\
2.60 \\
3.40\end{array}$ & $\begin{array}{l}3.40 \\
6.10 \\
4.20 \\
2.90 \\
2.50 \\
2.20 \\
2.00 \\
1.90 \\
1.80 \\
1.70 \\
1.60 \\
1.60 \\
1.60 \\
1.80 \\
8.80 \\
12.00\end{array}$ & $\begin{array}{l}1.80 \\
1.70 \\
1.60 \\
1.60 \\
3.30 \\
3.00 \\
3.00 \\
2.90 \\
3.10 \\
3.20 \\
3.30 \\
3.40 \\
3.50 \\
3.50 \\
3.00 \\
2.60\end{array}$ & $\begin{array}{l}2.50 \\
3.40 \\
4.70 \\
3.60 \\
3.30 \\
3.20 \\
2.90 \\
2.70 \\
2.60 \\
2.50 \\
2.40 \\
2.40 \\
2.40 \\
2.30 \\
2.30 \\
2.30\end{array}$ & $\begin{array}{l}2.90 \\
2.80 \\
2.70 \\
3.00 \\
3.20 \\
3.30 \\
3.20 \\
3.00 \\
2.80 \\
2.70 \\
2.60 \\
2.60 \\
2.70 \\
4.70 \\
3.00 \\
3.70\end{array}$ & $\begin{array}{l}17 \ldots \ldots \\
18 \ldots \ldots \\
19 \\
20 \ldots \\
21 \\
22 \\
23 \\
23 \\
24 \\
25 \\
26 \\
26 \\
27 \ldots \\
28 \\
29 \\
30 \ldots \\
31\end{array}$ & $\begin{array}{l}\ldots . . \\
2.95 \\
2.80 \\
3.05 \\
2.75 \\
2.65 \\
2.55 \\
2.65 \\
2.60 \\
2.50 \\
2.70 \\
6.50 \\
7.60 \\
5.00\end{array}$ & $\begin{array}{l}3.00 \\
2.80 \\
4.00 \\
2.90 \\
2.40 \\
2.30 \\
2.40 \\
2.70 \\
2.50 \\
2.80 \\
2.60 \\
2.50 \\
2.40 \\
2.30 \\
2.80\end{array}$ & \begin{tabular}{l}
7.90 \\
5.00 \\
3.80 \\
3.00 \\
2.70 \\
2.50 \\
2.40 \\
2.30 \\
2.20 \\
2.10 \\
2.00 \\
2.00 \\
2.00 \\
1.90 \\
\hdashline...
\end{tabular} & $\begin{array}{l}2.60 \\
2.20 \\
2.10 \\
2.00 \\
1.90 \\
2.10 \\
5.00 \\
7.30 \\
6.40 \\
5.40 \\
4.20 \\
3.60 \\
2.90 \\
2.70 \\
2.60\end{array}$ & \begin{tabular}{l}
2.30 \\
2.20 \\
2.20 \\
2.20 \\
2.50 \\
3.20 \\
3.50 \\
3.20 \\
4.80 \\
5.90 \\
5.40 \\
3.40 \\
3.20 \\
3.10 \\
\hdashline...
\end{tabular} & $\begin{array}{l}3.20 \\
3.10 \\
3.00 \\
5.20 \\
6.80 \\
5.30 \\
4.90 \\
5.60 \\
4.70 \\
4.20 \\
3.90 \\
3.60 \\
3.40 \\
3.50 \\
7.50\end{array}$ \\
\hline
\end{tabular}


TALLAPOOSA RIVER NEAR MILSTEAD, ALABAMA.

This station was established August 7, 1897, at the bridge of the Tallassee and Montgomery Railway, about a fourth of a mile from Milstead. It is described in Water-Supply Paper No. 36, page 152. The gage was last verified December 3, 1900. Records of discharge measurements for 1899 will be found in the Twenty-first Annual Report, Part IV, page 151. During 1900 the following measurements were made by Max Hall:

February 23: Gage height, 9.20 feet: discharge, 9,956 second-feet.

March 5: Gage height, 6.70 feet: discharge, 7,088 second-feet.

December 3: Gage height, 2.95 feet; discharge, 3,031 second-feet.

Daily gage height, in feet, of Tallapoosa River near Milstead, Alabama, for 1900.

\begin{tabular}{|c|c|c|c|c|c|c|c|c|c|c|c|c|}
\hline$I$ & an. & Feb. & Mar. & Apr. & May. & June. & July. & Aug. & Sept. & Oct. & Nov. & Dec. \\
\hline & 70 & 2.50 & 13.20 & 5.50 & .30 & 2.60 & 9.00 & 6.50 & 2.70 & 1.80 & 2.50 & 3.30 \\
\hline & 2.60 & 2.40 & 10 & & 5.90 & 2. 70 & 9.10 & & & & & 3.30 \\
\hline 3. & 2.40 & 2.30 & 10.70 & 5.00 & 40 & 3.00 & 10.60 & 3. 50 & 8.10 & 1.50 & 6. 10 & 3.30 \\
\hline & 2.30 & 4.50 & 8.00 & 5.30 & .90 & 3.50 & 7.10 & 2.80 & 4.40 & 1.80 & 6.50 & 3.50 \\
\hline & 2.30 & 4.20 & 6.80 & 4.80 & 70 & 3. 30 & 8.00 & 2. 70 & 3.00 & 3. 30 & 7.10 & 3.90 \\
\hline & 2.30 & 4. & 6.10 & 4.70 & 3.90 & 3.50 & 5.20 & 2.50 & 2.40 & 6. & 50 & 3.90 \\
\hline & 2.20 & 4. & 5. 60 & 4.60 & 30 & 3.30 & 4.40 & 0 & 2.20 & & & 3. \\
\hline & 2. 20 & 3. 80 & 10.90 & 4.60 & 0 & 5.90 & 4. 00 & 0 & 2.00 & & & 3. \\
\hline & 2.20 & 5. & 13. 80 & 4.50 & & 9.70 & 3. 50 & 2.10 & 1.80 & & & 3. 10 \\
\hline 10 & 2.20 & 8.90 & 12.70 & 4.60 & 0 & 6.90 & 7.60 & 2.00 & 1.70 & & & 3.10 \\
\hline 11 & 2.60 & 19.00 & 10.00 & 5. 50 & & 5.60 & 5. 50 & 1.90 & 1. 70 & 3. & 2. 70 & 2.80 \\
\hline 13 & 7.30 & 30.00 & 7.90 & 10.60 & 0 & 4.60 & 4. 10 & 1.90 & 1. 60 & 2. 80 & 2.60 & 2.80 \\
\hline 13 & 6.00 & 43.25 & 6.60 & 11.50 & 3. 10 & 5.30 & 4. 70 & 1.80 & 1.50 & 3. 40 & 2.60 & 2.80 \\
\hline 14 & 4.50 & & 5. & 9.00 & 0 & 4.00 & 6.70 & 1.90 & 1.50 & & & 7.70 \\
\hline & 4.00 & 31. & 5. 40 & 6.60 & & 3. & 6.00 & 2.20 & 14.00 & 3 & 0 & 9.10 \\
\hline 16 & 3.40 & 2 & 7.00 & 5. 30 & 0 & 3 & 5. & 2. & 25 & & & 7.30 \\
\hline & 3.00 & 13.50 & 7.20 & & & 4. & 3. & 0 & 18 & & & 5.20 \\
\hline & 2.90 & 8.90 & 5. 60 & 13.90 & & 5. 90 & 3. & 2.50 & 11. & & & 4.20 \\
\hline & 3.70 & 7.0 & 5. 40 & 17.06 & 0 & 5. 00 & 3.60 & 4.00 & 5.30 & 2. & 0 & 4.00 \\
\hline & 9.50 & 6.10 & 6.00 & 15 & 90 & 5.90 & 3.10 & 4. 20 & 3.60 & 2. & & 8.60 \\
\hline & 7.50 & 6.50 & 11.40 & 16 & 0 & 5. & 3.00 & 2.50 & 0 & 1. & & 17.00 \\
\hline 29 & 5. 90 & 9.8 & 10.50 & 13 & & 5. & 2.80 & 0 & 0 & 2. & & 13.50 \\
\hline & 4. 60 & 9. & 7.60 & & & 0 & 2 . & 5 & & & & 10 \\
\hline & 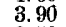 & 8 & 15 & 1 & 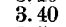 & 20 & 2. & 2 & 2 . & 12. & & 11.30 \\
\hline 25 & 3 & 8. & 15. 20 & 12.50 & 0 & 25. & 2.50 & 3.30 & & & 3. 50 & 8.70 \\
\hline & 3. 10 & 8.00 & 16.00 & 9.40 & 0 & 20 . & 2.50 & 3.40 & 2. & 9. & 10.50 & 6. 60 \\
\hline & 3.00 & 7.00 & 13. 70 & 7.50 & 0 & 16. & 2.80 & 3.60 & 2.00 & 6.00 & 8.80 & 5. 60 \\
\hline & 2.80 & 6.00 & 11.20 & 6.40 & 3.20 & 18.00 & 2.90 & 2. 70 & 2.00 & 4. 20 & 6. 70 & 5.00 \\
\hline & 2.70 & & 8.70 & 6.20 & & 13. 80 & 3. & & & & & 4.60 \\
\hline & 2.6 & & 7.10 & 6.10 & & 9.00 & & & 1. 90 & & 3.70 & \\
\hline & 2.50 & . & 6. 20 & 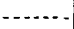 & 2.50 & $\ldots$. & 10.60 & 3.20 & $\ldots$ & 2.70 & $\cdots$ & 11.60 \\
\hline
\end{tabular}

ALABAMA RIVER AT MONTGOMERY, ALABAMA.

This station was established by the United States Engineer Corps a number of years ago, at the Montgomery wharf, near the union passenger station at the foot of Commerce street. The readings are now taken by the Weather Bureau, and copies are furnished to the Geological Survey. The station is described in Water-Supply Paper No. 36 , page 153. No measurements were made in 1899 or previous years. During 1900 one measurement was made by Max Hall, as follows:

March 6: Gage height, 11.40 feet; discharge, 29,470 second-feet. 
Daily gage height, in feet, of Alabama River at Montgomery, Alabama, for 1900.

\begin{tabular}{|c|c|c|c|c|c|c|c|c|c|c|c|c|}
\hline Day. & Jan. & Feb. & Mar. & Apr. & May. & June. & July. & Aug. & Sept. & Oct. & Nov. & Dec. \\
\hline & $\begin{array}{r}4.9 \\
4.3 \\
3.9 \\
3.5 \\
3.2 \\
2.9 \\
2.5 \\
2.2 \\
2.2 \\
2.2 \\
2.8 \\
8.0 \\
10.6 \\
10.6 \\
11.0 \\
11.0 \\
9.6 \\
8.0 \\
8.0 \\
10.0 \\
12.4 \\
14.6 \\
16.0 \\
15.4 \\
12.9 \\
11.6 \\
7.4 \\
7.0 \\
6.8 \\
6.4 \\
6.3\end{array}$ & $\begin{array}{r}6.0 \\
5.8 \\
5.3 \\
5.0 \\
6.0 \\
6.1 \\
6.1 \\
6.1 \\
6.1 \\
8.0 \\
14.2 \\
21.2 \\
31.2 \\
43.8 \\
48.4 \\
47.8 \\
44.5 \\
41.2 \\
37.5 \\
33.5 \\
35.5 \\
28.0 \\
23.6 \\
21.0 \\
18.6 \\
14.2 \\
12.8 \\
11.6 \\
\cdots \ldots . . \\
\cdots \ldots . . . \\
\ldots \ldots\end{array}$ & $\begin{array}{l}12.4 \\
17.6 \\
19.0 \\
19.4 \\
14.6 \\
11.8 \\
10.1 \\
10.1 \\
15.3 \\
18.6 \\
19.6 \\
19.5 \\
18.4 \\
16.5 \\
13.7 \\
11.7 \\
11.9 \\
11.3 \\
10.6 \\
13.3 \\
19.3 \\
22.5 \\
23.5 \\
25.1 \\
26.8 \\
28.1 \\
27.8 \\
25.6 \\
23.2 \\
20.5 \\
17.5\end{array}$ & $\begin{array}{r}14.0 \\
10.8 \\
9.2 \\
8.6 \\
8.1 \\
7.3 \\
7.3 \\
7.3 \\
7.3 \\
7.3 \\
7.3 \\
13.5 \\
20.5 \\
2.5 \\
24.0 \\
18.8 \\
16.8 \\
23.5 \\
29.0 \\
34.5 \\
36.4 \\
36.5 \\
33.5 \\
31.2 \\
29.3 \\
26.5 \\
22.2 \\
17.8 \\
14.6 \\
11.2\end{array}$ & $\begin{array}{r}10.2 \\
9.6 \\
9.2 \\
9.2 \\
8.3 \\
7.2 \\
6.6 \\
6.2 \\
5.6 \\
5.6 \\
5.3 \\
5.0 \\
5.0 \\
4.8 \\
4.6 \\
4.4 \\
4.0 \\
4.0 \\
4.0 \\
4.0 \\
4.0 \\
3.8 \\
3.8 \\
4.6 \\
4.9 \\
5.2 \\
5.0 \\
4.7 \\
4.5 \\
4.3 \\
3.8\end{array}$ & $\begin{array}{r}3.5 \\
3.5 \\
3.9 \\
4.5 \\
4.4 \\
4.4 \\
4.4 \\
5.0 \\
10.0 \\
11.0 \\
12.0 \\
12.0 \\
10.5 \\
9.5 \\
7.0 \\
6.2 \\
6.9 \\
8.1 \\
8.1 \\
9.0 \\
9.7 \\
10.2 \\
10.2 \\
14.2 \\
22.0 \\
27.4 \\
29.5 \\
30.8 \\
32.8 \\
31.8\end{array}$ & $\begin{array}{r}29.0 \\
24.8 \\
22.5 \\
20.2 \\
17.2 \\
14.8 \\
12.2 \\
9.8 \\
7.4 \\
6.4 \\
8.4 \\
7.6 \\
7.6 \\
8.0 \\
9.9 \\
10.0 \\
6.4 \\
5.2 \\
5.0 \\
4.8 \\
4.5 \\
4.0 \\
4.0 \\
3.8 \\
3.6 \\
3.6 \\
3.6 \\
5.2 \\
7.0 \\
9.2 \\
11.6\end{array}$ & $\begin{array}{r}10.6 \\
9.9 \\
6.6 \\
5.3 \\
4.5 \\
3.9 \\
3.3 \\
3.2 \\
3.0 \\
2.6 \\
2.6 \\
2.5 \\
2.4 \\
2.2 \\
2.2 \\
2.5 \\
2.5 \\
2.7 \\
3.1 \\
3.1 \\
3.0 \\
2.6 \\
2.7 \\
3.0 \\
3.0 \\
3.0 \\
3.0 \\
3.3 \\
3.3 \\
3.0 \\
2.9\end{array}$ & $\begin{array}{r}3.0 \\
3.5 \\
5.7 \\
5.0 \\
4.4 \\
2.9 \\
2.5 \\
2.0 \\
1.8 \\
1.6 \\
1.6 \\
1.4 \\
1.0 \\
1.2 \\
7.0 \\
16.0 \\
17.2 \\
16.7 \\
15.8 \\
10.2 \\
8.0 \\
4.7 \\
3.5 \\
3.0 \\
2.6 \\
2.4 \\
2.3 \\
2.0 \\
2.0 \\
1.7\end{array}$ & $\begin{array}{r}1.7 \\
1.6 \\
1.4 \\
1.4 \\
1.5 \\
3.0 \\
4.1 \\
3.9 \\
5.1 \\
3.7 \\
3.4 \\
4.0 \\
8.5 \\
8.0 \\
6.0 \\
5.2 \\
4.1 \\
3.7 \\
3.4 \\
2.6 \\
2.0 \\
1.9 \\
5.5 \\
8.0 \\
9.4 \\
8.2 \\
9.8 \\
10.6 \\
8.6 \\
5.5 \\
4.3\end{array}$ & $\begin{array}{r}3.7 \\
3.7 \\
4.2 \\
12.6 \\
10.6 \\
8.2 \\
5.7 \\
4.9 \\
4.5 \\
4.0 \\
3.5 \\
3.2 \\
3.0 \\
3.0 \\
2.7 \\
2.7 \\
2.5 \\
2.5 \\
2.3 \\
2.8 \\
1.7 \\
6.0 \\
7.0 \\
6.6 \\
6.6 \\
9.9 \\
13.0 \\
13.4 \\
13.4 \\
11.5\end{array}$ & $\begin{array}{r}10.6 \\
9.2 \\
7.0 \\
6.2 \\
5.8 \\
5.6 \\
6.7 \\
7.6 \\
7.8 \\
7.0 \\
6.0 \\
5.1 \\
4.5 \\
6.0 \\
9.0 \\
8.2 \\
7.1 \\
6.2 \\
5.0 \\
4.8 \\
10.0 \\
12.8 \\
14.0 \\
14.5 \\
14.0 \\
13.4 \\
10.6 \\
9.8 \\
8.8 \\
9.0 \\
10.0\end{array}$ \\
\hline
\end{tabular}

alabama Rivier at selma, Alabama.

This station was originally established by the United States Engineer Corps; readings are now taken by the United States Weather Bureau. The gage, which is attached to the iron highway bridge, the floor of which is about 60 feet above low water, is in two sections. The lower section, which reads from -3.0 feet to +2.30 feet, is secured to the pile on the lower side of the cofferdam on the draw pier; the upper section, which reads from 2.30 feet to 48 feet, is spiked to the highway bridge. The bench mark, which is an iron bolt driven into the face of a rock bluff 182.3 feet from the first bridge pier, on the road ascending to the city, is 26 feet above the zero of the gage and 87.30 feet above mean sea level. The top of the coping stone of the pivot pier at the highway bridge to which gage is attached is 56 feet above the zero of the gage and 117.30 feet above mean sea level. Graduations extend from -3.0 feet to +48 feet. During 1900 the following measurements were made:

April 14: Gage height, 23.60 feet; discharge, 66,607 second-feet. May 26: Gage height, 6.10 feet; discharge. 17,049 second-feet.

August 24: Gage height, 3.10 feet; discharge, 9,879 second-feet. 

OPERATIONS AT RIVER STATIONS, 1900.-PART II. [No.48.

Daily gage height, in feet, of Alabama River at Selma, Alabama, for 1900.

\begin{tabular}{c|r|r|r|r|r|r|r|r|r|r|r|r}
\hline Day. & Jan. & Feb. & Mar. & Apr. & May. & June. & July. & Aug. & Sept. & Oct. & Nov. & Dec. \\
\hline & & & & & & & & & & \\
1
\end{tabular}

BLACK WARRIOR RIVER AT TUSCALOOSA, ALABAMA.

A continuous record of the gage heights at Tuscaloosa has been kept by the United States Engineer Corps since 1889. During 1895 and 1896 a number of discharge measurements were made, from which a rating table was established. Since that time measurements of flow and computations of the discharge have been made regularly by the United States Geological Survey. The station is described in WaterSupply Paper No. 36, page 156. The records are furnished by R. C. McCalla, jr., United States assistant engineer. Records of measurements during 1899 will be found in the Twenty-first Annual Report, Part IV, page 153. No measurements were made during the year 1900. 
Daily gage height, in feet, of Black Warrior River at Tuscaloosa, Alabama, for 1900.

\begin{tabular}{|c|c|c|c|c|c|c|c|c|c|c|c|c|}
\hline Day & Jan. & Feb. & Mar. & Apr. & May. & June. & July. & Ang. & Sept. & Oct. & Nov. & Dec. \\
\hline $\begin{array}{l}28 \\
29 \\
30 \\
31 \\
31\end{array}$ & \begin{tabular}{|r}
10.90 \\
9.48 \\
8.32 \\
7.10 \\
6.18 \\
5.53 \\
5.12 \\
4.84 \\
4.60 \\
4.50 \\
37.12 \\
31.63 \\
31.80 \\
28.18 \\
24.09 \\
20.12 \\
16.50 \\
14.28 \\
15.80 \\
25.00 \\
32.60 \\
29.44 \\
24.54 \\
2.40 \\
17.43 \\
14.12 \\
12.14 \\
10.47 \\
9.10 \\
8.27 \\
7.60
\end{tabular} & \begin{tabular}{|c}
6.92 \\
6.40 \\
5.00 \\
5.17 \\
6.40 \\
9.58 \\
11.50 \\
1.53 \\
12.23 \\
20.60 \\
23.00 \\
20.64 \\
41.37 \\
47.96 \\
45.73 \\
40.23 \\
34.74 \\
29.75 \\
25.88 \\
2.43 \\
19.90 \\
$2 . .58$ \\
26.50 \\
24.20 \\
22.38 \\
21.00 \\
18.63 \\
1.6 .52
\end{tabular} & $\begin{array}{l}18.14 \\
25.44 \\
26.00 \\
23.30 \\
20.29 \\
17.43 \\
15.34 \\
27.58 \\
39.00 \\
36.03 \\
31.63 \\
27.34 \\
23.78 \\
20.43 \\
17.40 \\
16.63 \\
21.18 \\
20.28 \\
18.80 \\
45.10 \\
51.00 \\
4.98 \\
42.40 \\
38.24 \\
35.41 \\
36.78 \\
35.33 \\
31.80 \\
28.85 \\
26.25 \\
24.20\end{array}$ & \begin{tabular}{|l}
21.55 \\
18.60 \\
15.80 \\
13.60 \\
12.27 \\
12.17 \\
11.44 \\
10.29 \\
9.97 \\
10.58 \\
26.35 \\
52.79 \\
53.40 \\
48.69 \\
42.30 \\
37.10 \\
63.00 \\
64.05 \\
62.17 \\
59.35 \\
56.10 \\
51.71 \\
46.20 \\
41.88 \\
37.94 \\
33.94 \\
30.89 \\
28.15 \\
225.73 \\
23.50
\end{tabular} & \begin{tabular}{|c}
21.23 \\
18.95 \\
16.33 \\
13.82 \\
11.60 \\
9.60 \\
8.20 \\
7.28 \\
6.80 \\
6.50 \\
6.12 \\
5.90 \\
5.48 \\
4.98 \\
4.50 \\
3.85 \\
3.65 \\
3.50 \\
3.52 \\
3.39 \\
3.65 \\
3.50 \\
3.35 \\
4.40 \\
7.55 \\
7.68 \\
6.70 \\
5.30 \\
4.25 \\
3.60 \\
3.62
\end{tabular} & \begin{tabular}{|r|}
4.24 \\
5.30 \\
13.95 \\
15.16 \\
20.98 \\
21.50 \\
20.92 \\
21.75 \\
38.25 \\
31.70 \\
24.73 \\
19.60 \\
15.95 \\
15.60 \\
19.23 \\
29.15 \\
28.89 \\
25.33 \\
24.51 \\
30.10
\end{tabular} & \begin{tabular}{|r}
41.00 \\
33.88 \\
32.27 \\
32.13 \\
30.96 \\
27.31 \\
23.70 \\
20.80 \\
18.45 \\
15.96 \\
12.96 \\
11.05 \\
11.60 \\
12.90 \\
10.35 \\
8.50 \\
7.00 \\
6.00 \\
5.60 \\
8.55 \\
8.00 \\
8.10 \\
8.70 \\
7.40 \\
6.80 \\
9.20 \\
16.20 \\
13.50 \\
11.83 \\
11.05
\end{tabular} & 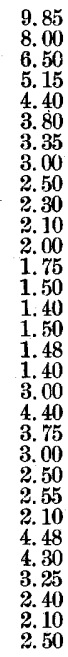 & \begin{tabular}{|r}
$\mathbf{5} .50$ \\
$\mathbf{5 . 0 0}$ \\
4.07 \\
4.30 \\
3.58 \\
3.80 \\
2.30 \\
1.90 \\
1.50 \\
1.40 \\
1.10 \\
.90 \\
1.80 \\
1.40 \\
10.65 \\
8.95 \\
6.34 \\
4.44 \\
3.35 \\
2.60 \\
2.20 \\
1.87 \\
1.65 \\
1.60 \\
1.45 \\
1.30 \\
1.05 \\
.90 \\
.75
\end{tabular} & $\begin{array}{r}0.75 \\
.80 \\
.60 \\
.25 \\
.40 \\
.40 \\
1.80 \\
3.80 \\
6.90 \\
6.05 \\
64.30 \\
22.50 \\
21.85 \\
16.40 \\
11.60 \\
8.20 \\
6.13 \\
5.10 \\
4.30 \\
3.60 \\
3.15 \\
4.60 \\
7.30 \\
10.40 \\
8.55 \\
6.75 \\
5.40 \\
4.70 \\
4.10 \\
3.70\end{array}$ & \begin{tabular}{|r}
4.20 \\
5.10 \\
5.40 \\
5.55 \\
5.05 \\
4.45 \\
3.90 \\
3.50 \\
3.10 \\
2.90 \\
2.70 \\
2.50 \\
2.40 \\
2.25 \\
2.20 \\
2.10 \\
2.05 \\
2.00 \\
1.95 \\
3.90 \\
8.40 \\
10.25 \\
12.50 \\
11.00 \\
9.45 \\
15.90 \\
22.20 \\
21.00 \\
17.35 \\
14.00
\end{tabular} & $\begin{array}{r}12.50 \\
9.65 \\
8.50 \\
7.90 \\
8.92 \\
10.20 \\
10.65 \\
9.65 \\
8.75 \\
8.15 \\
7.50 \\
6.90 \\
6.45 \\
6.40 \\
6.65 \\
6.45 \\
6.10 \\
5.75 \\
5.30 \\
5.45 \\
6.20 \\
8.35 \\
11.90 \\
17.90 \\
18.70 \\
17.00 \\
14.60 \\
12.50 \\
10.95 \\
10.15 \\
14.20\end{array}$ \\
\hline
\end{tabular}

BLACK WARRIOR RIVER NEAR CORDOVA, ALABAMA.

This station is located at the Kansas City, Memphis and Birmingham Railroad bridge three-fourths of a mile from Cordova, Alabama. The gage was established by the United States Weather Bureau, but records were discontinued by that bureau some time ago. From 12 to 55 feet the gage is a vertical timber bolted to the inside of the bridge pier on the left bank of the river. Below 12 feet the gage was sloping, but it was out of position and could not be used when the station was established by the Geological Survey on May 21, 1900, so a short new section was put in at that time. This section is a 2-inch by 10-inch plank, graduated to feet and tenths, marked with nails from -1.5 feet to +12.5 feet, and spiked to a willow tree on the right bank of the river about 200 feet below the bridge. The bench mark is the top of the stone pier on the left bank, and is 54.95 feet above the zero of the gage. Measurements are made from the railroad bridge, which is a single-span, iron, through bridge 300 feet long. The section is a good one. The observer is A. B. Logan, who lives on the right bank of the river, only a few hundred feet from the end of the bridge. During 1900 one measurement was made by Max Hall, as follows:

May 21: Gage height, 0.10 foot; discharge, 74i second-feet. 
Daily gage height, in feet, of Black Warrior River near Cordova, Alabama, for 1900.

\begin{tabular}{|c|c|c|c|c|c|c|c|c|}
\hline Day. & May. & June. & July. & Aug. & Sept. & Oct. & Nov. & Dec. \\
\hline $\begin{array}{r}1 \\
2 \\
3\end{array}$ & $\begin{array}{r}0.1 \\
.1 \\
.1 \\
1.5 \\
1.5 \\
1.0 \\
.6 \\
.7 \\
.8 \\
.9 \\
.9\end{array}$ & \begin{tabular}{r|}
0.6 \\
2.8 \\
5.3 \\
7.1 \\
7.5 \\
7.6 \\
6.5 \\
7.3 \\
6.5 \\
4.5 \\
3.2 \\
3.0 \\
4.6 \\
8.6 \\
9.8 \\
8.0 \\
8.2 \\
7.2 \\
13.4 \\
10.0 \\
6.1 \\
6.5 \\
15.2 \\
32.9 \\
3.8 \\
31.3 \\
2.1 \\
23.9 \\
2.4 \\
16.5
\end{tabular} & $\begin{array}{r}8.1 \\
5.2 \\
7.1 \\
6.5 \\
5.3 \\
4.6 \\
3.5 \\
2.1 \\
2.5 \\
2.7 \\
1.0 \\
.8 \\
1.0 \\
.8 \\
.5 \\
.4 \\
.4 \\
.3 \\
.3 \\
.2 \\
.7 \\
1.0 \\
.8 \\
.5 \\
.9 \\
.5 \\
1.6 \\
2.4 \\
1.3 \\
1.2 \\
1.5\end{array}$ & $\begin{array}{r}0.9 \\
.5 \\
.4 \\
.2 \\
.1 \\
.0 \\
.1 \\
.2 \\
.3 \\
.3 \\
.4 \\
.5 \\
.5 \\
.5 \\
.6 \\
.6 \\
.6 \\
.6 \\
.1 \\
.0 \\
.2 \\
.3 \\
.4 \\
.8 \\
1.7 \\
.8 \\
.2 \\
.0 \\
.1 \\
.9 \\
1.0\end{array}$ & $\begin{array}{r}0.5 \\
.2 \\
.1 \\
=.0 \\
=.2 \\
=.3 \\
=.4 \\
=.5 \\
=.6 \\
=.6 \\
=.7 \\
1.5 \\
.9 \\
.5 \\
.0 \\
=.1 \\
=.2 \\
=.3 \\
=.3 \\
=.4 \\
=.5 \\
=.5 \\
=.6 \\
=.7 \\
=.7\end{array}$ & $\begin{array}{r}-0.8 \\
\cdots .8 \\
-.9 \\
.9 \\
-1.0 \\
-1.0 \\
-1.1 \\
+.2 \\
.9 \\
.9 \\
9.4 \\
9.2 \\
3.2 \\
2.3 \\
1.7 \\
1.0 \\
.6 \\
.3 \\
.2 \\
.1 \\
1.0 \\
.7 \\
.5 \\
.3 \\
.2 \\
.1 \\
.0 \\
-.1 \\
-.1\end{array}$ & \begin{tabular}{r}
-0.1 \\
+.5 \\
.8 \\
.4 \\
.3 \\
.3 \\
.2 \\
.2 \\
.1 \\
.0 \\
\hdashline .1 \\
.2 \\
.2 \\
.3 \\
. .3 \\
. .3 \\
+.3 \\
.2 \\
.1 \\
1.3 \\
1.8 \\
.8 \\
.9 \\
5.1 \\
4.9 \\
3.6 \\
2.8 \\
1.9
\end{tabular} & $\begin{array}{r}1.4 \\
1.0 \\
.8 \\
1.0 \\
1.9 \\
1.4 \\
1.2 \\
1.0 \\
.8 \\
.7 \\
.7 \\
.8 \\
.8 \\
.6 \\
.5 \\
.4 \\
.5 \\
1.5 \\
3.0 \\
2.9 \\
5.0 \\
4.0 \\
3.1 \\
2.5 \\
2.1 \\
1.8 \\
1.7 \\
2.8\end{array}$ \\
\hline
\end{tabular}

HILLABEE CREEK NEAR ALEXANDER CITY, ALABAMA.

This station, which was established August 29, 1900, by J. R. Hall, is located $6 \frac{1}{2}$ miles northeast of Alexander City, on the road leading from that town to Newsite. The gage, which is graduated to feet and tenths and is placed vertically, is in two sections, the short section, which reads from 0 to 5.50 feet, being fastened to a post in the edge of the water on the north bank 20 feet from the upstream side of the bridge, the long section, which reads from 5.50 feet to 16 feet, being fastened to the upstream end of the first pier on the north bank, and arranged so that when water rises above the short section the readings are made from the long one, both sections being easily read from the north approach to the bridge. The initial point of sounding is on the south side of the first pier on the north hank. The gage is referred to a bench mark at the top of a chord on the downstream side of the bridge at the second pier from the north bank, and is 27.6 feet above the zero of the gage. The bridge is in three spans having a total length of 276 feet, with a north approach of 116 feet and a south approach of 124 feet, making a total, over all, of 516 feet. The observer is J. H. Chisholm, a farmer, post-office address Alexander City, Alabama. During 1900 the following measurements were made by James R. Hall:

August 29: Gage height, 1.40 feet; discharge, 184 second-feet.

November 28: Gage height, 2 feet; discharge, 390 second-feet. 
Daily gage height, in feet, of Hillabee Creek near Alexander City, Alabama, for 1900.

\begin{tabular}{|c|c|c|c|c|c|c|c|c|c|c|c|}
\hline Day. & Aug. & Sept. & Oct. & Nov. & Dec. & Day. & Ang. & Sept. & Oct. & Nov. & Dec. \\
\hline $\begin{array}{r}1 \\
2 \\
2 \\
3 \\
4\end{array}$ & 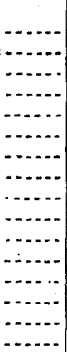 & $\begin{array}{l}2.3 \\
2.3 \\
1.6 \\
1.4 \\
1.3 \\
1.2 \\
1.2 \\
1.1 \\
1.1 \\
1.2 \\
1.1 \\
1.1 \\
1.1 \\
1.1 \\
8.1 \\
5.0\end{array}$ & $\begin{array}{l}1.3 \\
1.1 \\
1.1 \\
1.1 \\
3.2 \\
2.0 \\
2.8 \\
2.6 \\
2.4 \\
2.3 \\
2.3 \\
1.8 \\
1.6 \\
1.4 \\
1.4 \\
1.2\end{array}$ & $\begin{array}{l}1.6 \\
2.6 \\
6.8 \\
3.2 \\
2.2 \\
1.8 \\
1.7 \\
1.7 \\
1.8 \\
1.7 \\
1.7 \\
1.7 \\
1.7 \\
1.7 \\
1.7 \\
1.6\end{array}$ & \begin{tabular}{l||}
1.9 \\
1.9 \\
1.8 \\
1.9 \\
1.9 \\
1.8 \\
1.7 \\
1.7 \\
1.7 \\
1.7 \\
1.8 \\
3.8 \\
2.9 \\
2.8
\end{tabular} & $\begin{array}{l}17 \\
18 \\
19 \\
20 \\
21 \\
22 \\
23 \\
24 \\
25 \\
26 \\
26 \\
28 \\
28 \\
29 \\
30 \\
31\end{array}$ & 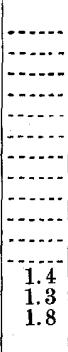 & $\begin{array}{l}2.6 \\
2.2 \\
1.6 \\
1.5 \\
1.5 \\
1.4 \\
1.2 \\
1.3 \\
1.4 \\
1.3 \\
1.4 \\
1.3 \\
1.4 \\
1.3\end{array}$ & $\begin{array}{l}1.3 \\
1.3 \\
1.2 \\
1.2 \\
1.2 \\
1.9 \\
5.9 \\
2.9 \\
2.1 \\
1.9 \\
1.8 \\
1.7 \\
1.6 \\
1.5 \\
1.5\end{array}$ & $\begin{array}{l}1.5 \\
1.4 \\
1.5 \\
1.6 \\
1.7 \\
2.1 \\
1.9 \\
1.9 \\
5.1 \\
2.9 \\
2.4 \\
2.0 \\
1.9 \\
1.9\end{array}$ & $\begin{array}{l}2.7 \\
2.8 \\
3.0 \\
2.9 \\
6.0 \\
4.0 \\
3.0 \\
2.9 \\
2.9 \\
2.8 \\
2.6 \\
2.5 \\
2.5 \\
5.8 \\
5.7\end{array}$ \\
\hline
\end{tabular}

TALLADEGA CREEK AT NOTTINGHAM, ALABAMA.

This station is located on the Southern Railroad bridge a fourth of a mile from the depot at Nottingham, Alabama, and 1 mile north of Alpine, Alabama. The gage, which is graduated to feet and tenths and is 20 feet long, is fastened vertically to the north end of the bridge on the upstream side, the bottom end of the gage being nailed to an old mudsill projecting from the north bank. The initial point of sounding is at the gage. The bench mark is the top rail on the upstream side of the bridge, and is 24.13 feet above gage datum. The section is a good one and is free from piers. The observer is R. M. McClatchy, station agent at Nottingham. During 1900 the following measurements were made by James R. Hall:

August 16: Gage beight, 1.10 feet; discharge, 102 second-feet.

November 29: Gage height, 1.70 feet; discharge, 240 second-feet.

Daily gage height, in feet, of Talladega Creek at Nottingham, Alabama, for 1900.

\begin{tabular}{|c|c|c|c|c|c|c|c|c|c|c|c|}
\hline Day. & Aug. & Sept. & Oct. & Nor. & Dec. & Day. & Aug. & Sept. & Oct. & Nov & Dec. \\
\hline $\begin{array}{r}1 \\
1 \\
2\end{array}$ & 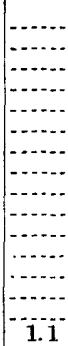 & $\begin{array}{r}1.2 \\
2.0 \\
1.3 \\
1.1 \\
1.0 \\
1.0 \\
1.0 \\
.9 \\
11.0 \\
8.0 \\
10.3 \\
8.0 \\
8.3 \\
9.3 \\
9.3 \\
3.9\end{array}$ & $\begin{array}{l}1.0 \\
1.0 \\
1.0 \\
1.0 \\
1.2 \\
1.3 \\
1.3 \\
1.4 \\
1.3 \\
1.3 \\
1.3 \\
1.5 \\
1.4 \\
1.3 \\
1.2 \\
1.2\end{array}$ & $\begin{array}{l}1.3 \\
1.3 \\
2.3 \\
2.1 \\
1.7 \\
1.5 \\
1.4 \\
1.4 \\
1.3 \\
1.3 \\
1.3 \\
1.2 \\
1.2 \\
1.2 \\
1.2\end{array}$ & $\begin{array}{l}1.6 \\
1.4 \\
1.4 \\
1.8 \\
1.7 \\
1.6 \\
1.5 \\
1.5 \\
1.4 \\
1.3 \\
1.3 \\
1.6 \\
1.8 \\
1.7 \\
1.6\end{array}$ & 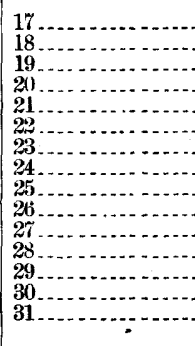 & $\begin{array}{l}1.2 \\
1.2 \\
1.1 \\
1.1 \\
1.1 \\
1.1 \\
1.1 \\
1.0 \\
1.0 \\
1.1 \\
1.2 \\
1.0 \\
1.0 \\
1.6\end{array}$ & $\begin{array}{l}2.3 \\
1.7 \\
1.6 \\
1.5 \\
1.3 \\
1.2 \\
1.2 \\
1.2 \\
1.2 \\
1.2 \\
1.2 \\
1.2 \\
1.1 \\
1.1\end{array}$ & $\begin{array}{l}1.1 \\
1.1 \\
1.1 \\
1.0 \\
1.2 \\
1.4 \\
1.6 \\
2.9 \\
3.5 \\
3.0 \\
2.6 \\
1.4 \\
1.3 \\
1.3 \\
1.3\end{array}$ & $\begin{array}{l}1.2 \\
1.2 \\
1.2 \\
1.5 \\
2.2 \\
1.9 \\
1.8 \\
1.6 \\
3.9 \\
3.8 \\
3.4 \\
2.0 \\
1.8 \\
1.7\end{array}$ & $\begin{array}{l}1.5 \\
1.5 \\
1.4 \\
2.7 \\
3.0 \\
2.6 \\
4.0 \\
2.5 \\
2.1 \\
2.0 \\
1.8 \\
1.7 \\
1.6 \\
1.9 \\
5.1\end{array}$ \\
\hline
\end{tabular}




\section{BIG SANDY CREEK NEAR DADEVILLE, ALABAMA.}

This station, which was established by J. R. Hall August 2, 1900, is located about $4 \frac{1}{2}$ miles southwest of Dadeville, at the highway bridge on the Dadeville-Susanna road. The gage, which is graduated to feet and tenths, is 16 feet high and is fastened vertically to the first pier on the north side of the creek. The initial point of sounding is at the gage rod. The section is good for ordinary or flood measurements, but is rather wide and shoaly for low-water measurements. The latter can, however, be made a short distance from the gage. The observer is L. H. Finch, a farmer who lives 200 yards from the station, postoffice address, Dadeville, Alabama. During 1900 the following measurements were made by James $R$. Hall:

July 6: Gage height, 1.20 feet; discharge, 260 second-feet.

August 8: Gage height, 1.00 foot; discharge, 110 second-feet.

August 8: Gage height, 1.00 foot; discharge, 116 second-feet.

August 25: Gage height, 1.35 feet: discharge, 281 second-feet.

November 16: Gage height, 1.10 feet; discharge, 155 second-feet.

December 31: Gage height, 2.00 feet; discharge, 870 second-feet.

The measurements of August 8 and November 16 were made a half mile below Smith's bridge.

Daily gage height, in feet, of Big Sandy Creek near Dadeville, Alabama, for 1900.

\begin{tabular}{|c|c|c|c|c|c|c|c|c|c|c|c|}
\hline Day. & Aug. & Sept. & Det. & Nov. & Dec. & Day. & Aug. & Sept. & Oct. & Nov. & Dec. \\
\hline 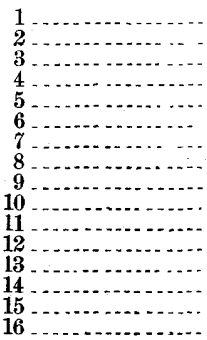 & $\begin{array}{l}1.00 \\
1.20 \\
1.10 \\
1.10 \\
1.10 \\
1.05 \\
1.05 \\
1.00 \\
1.05 \\
1.00 \\
1.00 \\
9.05 \\
9.00 \\
9.00 \\
1.80 \\
1.00\end{array}$ & $\begin{array}{l}1.10 \\
1.10 \\
1.40 \\
1.50 \\
1.20 \\
1.05 \\
1.00 \\
1.00 \\
.95 \\
2.00 \\
1.80 \\
1.40 \\
1.20 \\
1.20 \\
2.00 \\
2.20\end{array}$ & $\begin{array}{r}0.95 \\
.90 \\
.90 \\
.90 \\
3.50 \\
1.80 \\
1.25 \\
1.20 \\
1.10 \\
1.15 \\
1.10 \\
1.20 \\
1.30 \\
1.15 \\
1.10 \\
1.05\end{array}$ & $\begin{array}{l}1.00 \\
1.30 \\
2.00 \\
1.80 \\
1.40 \\
1.20 \\
1.20 \\
1.20 \\
1.15 \\
1.15 \\
1.15 \\
1.15 \\
1.10 \\
1.10 \\
1.10 \\
1.10\end{array}$ & $\begin{array}{l}1.10 \\
1.15 \\
1.25 \\
1.40 \\
1.35 \\
1.30 \\
1.25 \\
1.20 \\
1.15 \\
1.10 \\
1.10 \\
1.10 \\
1.10 \\
2.20 \\
1.80 \\
1.45\end{array}$ & $\begin{array}{l}18 \\
18 \\
19 \\
29 \\
21 \\
21 \\
22 \\
23\end{array}$ & $\begin{array}{r}1.80 \\
1.20 \\
1.10 \\
1.00 \\
1.00 \\
.90 \\
.90 \\
1.70 \\
1.40 \\
1.60 \\
1.15 \\
1.10 \\
1.00 \\
1.00 \\
1.80\end{array}$ & $\begin{array}{l}3.90 \\
1.50 \\
1.10 \\
1.05 \\
1.00 \\
1.00 \\
1.00 \\
1.00 \\
1.00 \\
1.00 \\
1.05 \\
1.05 \\
1.00 \\
.90 \\
-. .-\end{array}$ & $\begin{array}{l}1.10 \\
1.00 \\
1.05 \\
1.05 \\
1.00 \\
1.50 \\
1.45 \\
1.40 \\
1.20 \\
1.15 \\
1.10 \\
1.05 \\
1.05 \\
1.00 \\
1.05\end{array}$ & $\begin{array}{l}1.15 \\
1.10 \\
1.10 \\
1.10 \\
1.10 \\
1.30 \\
1.25 \\
1.20 \\
1.50 \\
1.90 \\
1.80 \\
1.20 \\
1.15 \\
1.10 \\
-. . .\end{array}$ & $\begin{array}{l}1.45 \\
1.30 \\
2.40 \\
4.50 \\
3.50 \\
1.70 \\
1.50 \\
1.40 \\
1.40 \\
1.35 \\
1.35 \\
1.35 \\
1.30 \\
1.75 \\
2.00\end{array}$ \\
\hline
\end{tabular}

TOMBIGBEE RIVER AT COLUMBUS, MISSISSIPPI.

This station is located about 1,000 feet below the highway bridge $1 \frac{1}{2}$ miles from the Southern Railway depot at Columbus. The rod, which is in three sections, is fastened vertically to the rock bluff on the left bank. It is a 3-inch by 10 -inch pine timber 45 feet long, marked with brass figures and copper nails, the graduation extending from -5.0 feet to +40.0 feet. The initial point of sounding is the end of the iron bridge, right bank, downstream side. Bench mark No. 1 is 250 feet from the initial point of sounding. The bridge floor is 40.85 feet above the zero of the rod, and the top of the iron girder 
under the floor timbers is 39.85 feet above the zero. Bench mark No. 2 is the top of the rail at the depot of the Southern Railway, and is 55.2 feet above gage datum and 190.9 feet above mean sea level. The width of the river at low water is 160 feet. The maximum recorded height of the river was on April 8, 1892, when the gage registered 42 feet. The lowest recorded height was on October 26,1893 , when the gage reading was -3.9 feet. The danger line is at 33 feet. No measurements of discharge were made during 1900.

Daily gage height, in feet, of Tombigbee River at Columbus, Mississippi, for 1900 .

\begin{tabular}{|c|c|c|c|c|c|c|c|c|c|c|c|c|}
\hline Day. & Jan. & Feb. & Mar. & Apr. & May. & June. & July. & Aug. & Sept. & oct. & Nov. & Dec. \\
\hline $\begin{array}{l}29 \\
30 \\
31\end{array}$ & $\begin{array}{r}3.5 \\
2.2 \\
1.8 \\
1.6 \\
1.4 \\
1.2 \\
1.1 \\
1.0 \\
.9 \\
2.0 \\
2.6 \\
8.3 \\
7.1 \\
5.6 \\
4.6 \\
2.8 \\
2.4 \\
2.2 \\
2.1 \\
1.9 \\
1.8 \\
1.4 \\
1.2 \\
1.1 \\
.9 \\
.7 \\
.6 \\
.5 \\
.4\end{array}$ & $\begin{array}{r}0.4 \\
.3 \\
.2 \\
.4 \\
1.8 \\
3.5 \\
3.5 . \\
3.3 \\
4.2 \\
8.4 \\
7.8 \\
7.6 \\
10.2 \\
9.8 \\
8.1 \\
5.8 \\
4.6 \\
3.8 \\
3.2 \\
2.8 \\
3.5 \\
5.6 \\
5.4 \\
4.5 \\
5.0 \\
5.0 \\
3.9 \\
4.2\end{array}$ & $\begin{array}{r}7.1 \\
6.8 \\
5.6 \\
4.4 \\
3.8 \\
3.4 \\
7.6 \\
14.4 \\
15.1 \\
13.8 \\
11.3 \\
9.9 \\
6.7 \\
4.3 \\
4.8 \\
5.6 \\
5.2 \\
4.6 \\
9.4 \\
15.6 \\
18.2 \\
19.0 \\
19.2 \\
18.1 \\
15.2 \\
11.4 \\
7.8 \\
4.6 \\
3.9 \\
3.1 \\
3.3\end{array}$ & $\begin{array}{r}4.5 \\
3.8 \\
2.7 \\
1.9 \\
1.5 \\
1.3 \\
1.3 \\
1.1 \\
.7 \\
.5 \\
11.7 \\
16.2 \\
17.4 \\
19.3 \\
20.8 \\
20.9 \\
22.9 \\
26.9 \\
27.6 \\
27.5 \\
27.1 \\
25.5 \\
23.3 \\
21.3 \\
19.4 \\
17.3 \\
14.8 \\
11.8 \\
9.5 \\
9.4\end{array}$ & $\begin{array}{r}8.0 \\
6.5 \\
5.9 \\
4.5 \\
2.8 \\
1.5 \\
.8 \\
1.5 \\
1.4 \\
2.3 \\
3.3 \\
3.6 \\
2.8 \\
2.2 \\
1.6 \\
+.7 \\
-.0 \\
1.4 \\
1.0 \\
.5 \\
.5 \\
+.1 \\
.2 \\
.3 \\
2.3 \\
2.4 \\
2.2 \\
1.6 \\
1.0 \\
.8\end{array}$ & $\begin{array}{r}1.0 \\
8.0 \\
10.0 \\
13.4 \\
15.3 \\
17.0 \\
20.7 \\
23.6 \\
25.5 \\
25.0 \\
23.6 \\
21.6 \\
20.0 \\
18.5 \\
17.8 \\
17.1 \\
17.3 \\
17.8 \\
18.0 \\
16.8 \\
15.2 \\
13.5 \\
13.8 \\
18.5 \\
21.5 \\
24.1 \\
25.0 \\
24.8 \\
23.5 \\
21.7\end{array}$ & $\begin{array}{r}19.7 \\
18.3 \\
17.6 \\
16.2 \\
15.9 \\
15.4 \\
14.5 \\
13.5 \\
10.0 \\
6.8 \\
5.5 \\
4.0 \\
3.5 \\
2.0 \\
1.9 \\
1.5 \\
1.0 \\
.5 \\
.0 \\
.4 \\
1.3 \\
2.0 \\
1.9 \\
1.4 \\
.7 \\
1.8 \\
5.0 \\
5.9 \\
6.7 \\
7.2\end{array}$ & $\begin{array}{r}5.8 \\
4.0 \\
2.8 \\
1.9 \\
1.0 \\
. .0 \\
-.5 \\
-1.9 \\
-1.4 \\
-2.8 \\
-2.2 \\
-2.6 \\
-2.7 \\
-2.2 \\
-2.2 \\
-2.3 \\
-2.3 \\
-1.8 \\
-1.4 \\
-1.1 \\
-1.9 \\
-2.0 \\
-2.1 \\
+1.2 \\
\pm .6 \\
-1.0 \\
-1.4 \\
-1.1\end{array}$ & $\begin{array}{l}-1.2 \\
-1.0 \\
-1.0 \\
=.7 \\
=.6 \\
-1.9 \\
-1.9 \\
-2.1 \\
-2.3 \\
-2.4 \\
-2.5 \\
-2.6 \\
-2.7 \\
-2.7 \\
-2.8 \\
-2.9 \\
-3.0 \\
-3.0 \\
-3.0 \\
-2.9 \\
-2.7 \\
-1.3 \\
-1.7 \\
-2.0 \\
-2.2 \\
-2.4 \\
-2.5 \\
-2.5 \\
\cdots+. .\end{array}$ & $\begin{array}{l}-2.7 \\
-2.8 \\
-3.0 \\
-3.1 \\
-3.3 \\
-3.5 \\
-3.5 \\
-2.2 \\
-1.0 \\
-. .6 \\
-2.4 \\
+2.6 \\
+4.8 \\
+5.2 \\
+5.6 \\
+5.4 \\
+2.4 \\
+.44 \\
-.49 \\
-1.1 \\
-1.3 \\
-1.0 \\
-1.2 \\
+. .8 \\
+1.0 \\
+5.1 \\
+5.6 \\
+4.6 \\
+4.0 \\
+3.0\end{array}$ & $\begin{array}{r}+2.6 \\
+4.9 \\
+5.5 \\
+5.1 \\
+4.4 \\
+3.1 \\
+1.9 \\
+.9 \\
\pm .1 \\
=.5 \\
-1.9 \\
-1.3 \\
-1.3 \\
-1.4 \\
-1.5 \\
-1.5 \\
-1.6 \\
-1.6 \\
-1.6 \\
-1.6 \\
+1.2 \\
+1.0 \\
+2.8 \\
+2.8 \\
+3.3 \\
+3.8 \\
+3.9 \\
+3.8\end{array}$ & $\begin{array}{r}+3.4 \\
+2.5 \\
+1.9 \\
+1.0 \\
+.1 \\
+.2 \\
+.3 \\
+.3 \\
. .0 \\
+.3 \\
+.6 \\
+.9 \\
+.9 \\
+.9 \\
+.9 \\
+1.0 \\
-1.0 \\
-1.0 \\
+1.0 \\
+5.0 \\
+6.0 \\
+6.6 \\
+6.8 \\
+6.1 \\
+5.0 \\
+4.2 \\
+4.8 \\
+4.0\end{array}$ \\
\hline
\end{tabular}

TOMBIGBEE RIVER NEAR EPES, ALABAMA.

A record of gage heights has been kept at this station for the last ten years by the Alabama Great Southern Railway Company. The gage is painted on the center brick pier of the railway bridge of that company across the Tombigbee a half mile east of Epes, and is referred to two bench marks, the first, the top of the iron girder at the third crossbeam at the station, 80 feet from the right-bank end of the iron bridge, is 64.70 feet above datum of gage, the second, the top of the cross-tie or the base of the rail at the station, 80 feet from the right-bank end of the iron bridge, is 65.50 feet above datum of gage. The west bank of the river is a solid wall of limestone, the east bank is flat and is subject to overflow. The trestle at the east end of the 
bridge is seven-eighths of a mile long. The section is good, though the water is very deep and rather swift.

Daily gage height, in feet, of Tombigbee River near Epes, Alabama, for 1900.

\begin{tabular}{|c|c|c|c|c|c|c|c|c|c|c|c|c|}
\hline Day & Jan. & Feb. & Mar. & Apr. & May. & June. & July. & Aug. & Sept. & Oct. & Nov. & Dec. \\
\hline $\begin{array}{r}1 \\
\begin{array}{r}1 \\
3\end{array} \\
4 \\
5\end{array}$ & $\begin{array}{r}8.5 \\
7.5 \\
6.5 \\
6.0 \\
5.5 \\
5.0 \\
4.5 \\
4.0 \\
3.5 \\
3.5 \\
13.0 \\
20.0 \\
23.0 \\
23.5 \\
22.0 \\
21.0 \\
18.5 \\
15.0 \\
11.5 \\
10.0 \\
8.5 \\
8.0 \\
8.0 \\
7.0 \\
6.5 \\
6.0 \\
5.0 \\
3.0 \\
3.0 \\
3.0 \\
3.0\end{array}$ & $\begin{array}{r}3.0 \\
3.0 \\
3.0 \\
3.0 \\
5.0 \\
6.0 \\
7.0 \\
7.5 \\
11.5 \\
13.5 \\
15.0 \\
20.5 \\
26.0 \\
28.0 \\
28.0 \\
26.0 \\
24.0 \\
22.0 \\
18.5 \\
16.0 \\
14.0 \\
15.0 \\
17.5 \\
18.0 \\
17.5 \\
17.0 \\
16.0 \\
17.0 \\
\ldots \ldots . . \\
\cdots \ldots . . . \\
\cdots \cdots . . .\end{array}$ & $\begin{array}{l}18.0 \\
19.0 \\
18.0 \\
17.0 \\
15.0 \\
14.0 \\
13.0 \\
18.0 \\
21.0 \\
23.0 \\
24.0 \\
24.0 \\
23.0 \\
.20 .0 \\
17.5 \\
17.0 \\
18.0 \\
18.0 \\
18.5 \\
26.0 \\
30.0 \\
32.0 \\
34.0 \\
35.5 \\
37.5 \\
38.0 \\
39.0 \\
38.5 \\
35.0 \\
33.0 \\
30.0\end{array}$ & $\begin{array}{r}24.5 \\
19.5 \\
16.0 \\
12.0 \\
10.0 \\
8.0 \\
7.5 \\
7.5 \\
7.0 \\
6.5 \\
20.5 \\
26.0 \\
29.0 \\
30.0 \\
31.0 \\
38.0 \\
46.0 \\
48.5 \\
51.0 \\
51.5 \\
52.0 \\
52.0 \\
51.5 \\
51.0 \\
49.5 \\
47.5 \\
47.0 \\
46.5 \\
46.0 \\
44.5\end{array}$ & $\begin{array}{l}43.0 \\
41.0 \\
39.0 \\
33.5 \\
28.0 \\
20.5 \\
16.0 \\
10.0 \\
7.0 \\
7.0 \\
7.0 \\
8.0 \\
8.0 \\
7.0 \\
6.0 \\
6.0 \\
5.0 \\
4.0 \\
3.5 \\
3.5 \\
3.5 \\
3.5 \\
3.5 \\
4.0 \\
4.5 \\
5.0 \\
6.0 \\
7.0 \\
7.0 \\
6.0 \\
5.0\end{array}$ & $\begin{array}{r}6.0 \\
8.0 \\
15.0 \\
21.0 \\
24.5 \\
27.0 \\
29.5 \\
32.0 \\
34.5 \\
37.0 \\
38.5 \\
39.5 \\
40.5 \\
41.0 \\
41.5 \\
42.0 \\
42.0 \\
42.0 \\
41.5 \\
41.5 \\
41.5 \\
41.0 \\
41.0 \\
42.5 \\
42.5 \\
43.5 \\
43.5 \\
43.5 \\
44.0 \\
44.5\end{array}$ & $\begin{array}{r}44.5 \\
44.5 \\
44.5 \\
44.0 \\
42.5 \\
42.0 \\
41.0 \\
.40 .0 \\
39.0 \\
38.0 \\
34.0 \\
26.0 \\
23.0 \\
15.5 \\
13.0 \\
8.0 \\
7.0 \\
6.0 \\
5.0 \\
6.5 \\
7.0 \\
8.0 \\
9.0 \\
8.0 \\
6.0 \\
5.5 \\
5.0 \\
5.5 \\
14.0 \\
14.5 \\
14.5\end{array}$ & $\begin{array}{r}14.5 \\
12.0 \\
10.5 \\
8.0 \\
6.0 \\
5.0 \\
5.0 \\
4.0 \\
3.0 \\
2.0 \\
2.0 \\
2.0 \\
2.0 \\
2.0 \\
2.0 \\
1.5 \\
1.5 \\
1.5 \\
1.5 \\
1.5 \\
1.0 \\
1.0 \\
2.0 \\
1.5 \\
1.5 \\
1.5 \\
\mathbf{5 . 0} \\
4.5 \\
4.0 \\
3.0 \\
2.0\end{array}$ & $\begin{array}{l}2.0 \\
2.5 \\
2.0 \\
2.0 \\
2.0 \\
2.0 \\
2.0 \\
2.0 \\
2.0 \\
2.0 \\
1.5 \\
1.5 \\
1.5 \\
2.0 \\
1.5 \\
1.0 \\
1.0 \\
1.0 \\
1.0 \\
.5 \\
.5 \\
.5 \\
.5 \\
.5 \\
.5 \\
.5 \\
.5 \\
.5 \\
.5 \\
.5\end{array}$ & $\begin{array}{r}0.5 \\
.5 \\
.5 \\
.5 \\
.5 \\
.5 \\
.5 \\
.5 \\
.5 \\
2.0 \\
4.0 \\
6.0 \\
7.5 \\
8.5 \\
10.0 \\
10.5 \\
10.0 \\
7.5 \\
5.0 \\
4.0 \\
3.5 \\
3.0 \\
2.0 \\
2.0 \\
3.0 \\
4.0 \\
4.5 \\
7.5 \\
9.0 \\
8.0 \\
7.5\end{array}$ & $\begin{array}{l}7.0 \\
8.0 \\
9.0 \\
8.5 \\
8.5 \\
7.5 \\
7.0 \\
5.5 \\
4.5 \\
4.0 \\
4.0 \\
3.0 \\
3.0 \\
2.5 \\
2.0 \\
2.0 \\
2.0 \\
2.0 \\
2.5 \\
2.5 \\
3.0 \\
3.5 \\
3.5 \\
3.5 \\
6.5 \\
8.5 \\
7.5 \\
7.5 \\
8.0 \\
8.5 \\
\ldots . . .\end{array}$ & $\begin{array}{r}8.0 \\
7.5 \\
7.0 \\
6.0 \\
5.0 \\
4.5 \\
4.0 \\
4.0 \\
4.0 \\
3.5 \\
3.0 \\
3.0 \\
3.5 \\
3.5 \\
3.5 \\
3.5 \\
3.0 \\
3.0 \\
3.0 \\
6.0 \\
5.0 \\
5.0 \\
8.5 \\
10.0 \\
11.5 \\
11.5 \\
.12 .5 \\
12.0 \\
10.0 \\
10.0 \\
10.5\end{array}$ \\
\hline
\end{tabular}

YOUGHIOGHENY RIVER AT FRIENDSVILLE, MARYLAND.

This station, which was established by E. G. Paul on August 17, 1898, is located at the iron highway bridge connecting the east and west portions of the village. It is described in Water-Supply Paper No. 36, page 159. Records of measurements for 1899 will be found in the Twenty-first Annual Report, Part IV, page 156. During 1900 the following measurements were made by E. G. Paul and C. R. Olberg:

February 15: Gage height, 6.2 feet; discharge, 1,816 second-feet.

June 26: Gage height, 4.6 feet; discharge, 361 second-feet.

September 13: Gage height, 3.8 feet; discharge, 48 second-feet. 
Daily gage height, in feet, of Youghiogheny River at Friendsville, Maryland, for 1900 .

\begin{tabular}{|c|c|c|c|c|c|c|c|c|c|c|c|c|}
\hline Day. & Jan. & Feb. & Mar. & Apr. & May. & June. & July. & Aug. & Sept. & Oct. & Nov. & Dec. \\
\hline $\begin{array}{l}24 \\
25 \\
26 \\
28 \\
28 \\
29 \\
20 \\
30 \\
31\end{array}$ & $\begin{array}{l}5.1 \\
5.1 \\
5.1 \\
5.1 \\
5.1 \\
5.1 \\
5.2 \\
5.3 \\
5.3 \\
5.3 \\
5.4 \\
6.3 \\
6.3 \\
6.0 \\
5.8 \\
5.8 \\
5.6 \\
5.6 \\
5.7 \\
6.0 \\
6.3 \\
6.1 \\
5.7 \\
5.5 \\
5.4 \\
5.3 \\
5.2 \\
5.0 \\
5.0 \\
5.0\end{array}$ & $\begin{array}{l}4.8 \\
4.8 \\
4.8 \\
4.8 \\
4.8 \\
5.4 \\
5.6 \\
6.6 \\
6.8 \\
6.6 \\
6.4 \\
6.2 \\
6.3 \\
6.4 \\
6.3 \\
\mathbf{0 . 1} \\
5.8 \\
5.6 \\
5.2 \\
5.1 \\
5.1 \\
5.0 \\
5.0 \\
5.0 \\
5.0 \\
5.0 \\
5.1 \\
5.1\end{array}$ & $\begin{array}{l}6.3 \\
6.8 \\
6.6 \\
6.3 \\
6.2 \\
6.3 \\
6.1 \\
6.0 \\
5.8 \\
5.7 \\
5.6 \\
5.5 \\
5.3 \\
5.3 \\
5.3 \\
5.4 \\
5.3 \\
5.5 \\
5.7 \\
5.9 \\
7.0 \\
6.5 \\
6.1 \\
5.8 \\
5.6 \\
5.5 \\
5.4 \\
5.4 \\
5.5 \\
5.7 \\
5.7\end{array}$ & $\begin{array}{l}5.8 \\
5.8 \\
5.8 \\
5.6 \\
5.5 \\
5.5 \\
5.5 \\
5.4 \\
5.4 \\
5.3 \\
5.3 \\
5.2 \\
5.1 \\
5.0 \\
5.0 \\
4.9 \\
4.9 \\
4.8 \\
4.8 \\
4.7 \\
4.7 \\
4.7 \\
4.6 \\
4.6 \\
4.7 \\
4.7 \\
4.8 \\
4.8 \\
4.7 \\
4.7\end{array}$ & $\begin{array}{l}4.6 \\
4.6 \\
4.5 \\
4.5 \\
4.5 \\
4.6 \\
4.6 \\
4.7 \\
4.7 \\
4.6 \\
4.5 \\
4.6 \\
4.7 \\
4.7 \\
4.8 \\
4.9 \\
4.9 \\
4.8 \\
4.7 \\
4.7 \\
4.7 \\
4.7 \\
4.7 \\
4.6 \\
4.5 \\
4.4 \\
4.4 \\
4.4 \\
4.4 \\
4.4 \\
4.4\end{array}$ & $\begin{array}{l}4.3 \\
4.3 \\
4.3 \\
4.4 \\
4.3 \\
4.3 \\
4.2 \\
4.2 \\
4.2 \\
4.2 \\
4.1 \\
4.1 \\
4.2 \\
4.5 \\
4.7 \\
5.4 \\
6.7 \\
7.1 \\
7.0 \\
6.5 \\
6.0 \\
5.3 \\
4.8 \\
4.7 \\
4.7 \\
4.6 \\
4.5 \\
4.6 \\
4.8 \\
4.9\end{array}$ & \begin{tabular}{l}
4.8 \\
4.8 \\
4.7 \\
4.8 \\
4.6 \\
4.4 \\
4.3 \\
\hdashline 4.3 \\
4.2 \\
4.2 \\
4.1 \\
4.1 \\
4.1 \\
4.1 \\
4.1 \\
4.0 \\
4.0 \\
4.0 \\
4.1 \\
4.1 \\
4.2 \\
4.3 \\
4.3 \\
4.4 \\
4.7 \\
5.0 \\
4.6 \\
4.7 \\
4.9 \\
5.5
\end{tabular} & $\begin{array}{l}4.7 \\
4.5 \\
4.3 \\
4.2 \\
4.2 \\
4.2 \\
4.1 \\
4.1 \\
4.0 \\
4.0 \\
4.0 \\
4.0 \\
4.0 \\
4.0 \\
4.1 \\
4.2 \\
4.5 \\
4.5 \\
4.4 \\
4.3 \\
4.2 \\
4.2 \\
4.6 \\
4.2 \\
4.3 \\
4.3 \\
4.1 \\
4.1 \\
4.2 \\
4.1 \\
4.1\end{array}$ & $\begin{array}{l}4.0 \\
4.0 \\
4.0 \\
4.0 \\
4.0 \\
4.0 \\
4.0 \\
3.9 \\
3.9 \\
3.9 \\
3.9 \\
3.9 \\
3.9 \\
3.9 \\
3.9 \\
3.8 \\
3.8 \\
3.8 \\
8.8 \\
3.8 \\
3.8 \\
3.8 \\
3.8 \\
3.8 \\
3.8 \\
3.8 \\
3.9 \\
3.9 \\
3.9 \\
3.9\end{array}$ & $\begin{array}{l}3.9 \\
3.9 \\
3.9 \\
3.9 \\
3.9 \\
3.9 \\
3.9 \\
3.9 \\
3.9 \\
3.9 \\
3.9 \\
3.9 \\
3.9 \\
4.1 \\
4.3 \\
4.3 \\
4.2 \\
4.2 \\
4.2 \\
4.1 \\
4.2 \\
4.2 \\
4.1 \\
4.0 \\
4.0 \\
4.0 \\
4.1 \\
4.2 \\
4.1 \\
4.1 \\
4.1\end{array}$ & $\begin{array}{l}4.1 \\
4.1 \\
4.1 \\
4.4 \\
4.3 \\
4.2 \\
4.2 \\
4.2 \\
4.4 \\
4.3 \\
4.3 \\
4.3 \\
4.3 \\
4.3 \\
4.2 \\
4.2 \\
4.2 \\
4.3 \\
4.4 \\
4.4 \\
4.5 \\
4.7 \\
4.8 \\
4.9 \\
5.2 \\
9.5 \\
8.3 \\
6.9 \\
5.8 \\
5.5\end{array}$ & $\begin{array}{l}5.3 \\
5.2 \\
5.1 \\
5.3 \\
5.6 \\
5.8 \\
7.5 \\
7.3 \\
6.9 \\
6.4 \\
6.1 \\
5.8 \\
5.6 \\
5.4 \\
5.4 \\
5.3 \\
5.1 \\
4.9 \\
4.7 \\
4.6 \\
4.6 \\
4.5 \\
4.3 \\
4.3 \\
4.4 \\
4.6 \\
4.8 \\
5.0 \\
5.2 \\
5.2\end{array}$ \\
\hline
\end{tabular}

CHEAT RIVER NEAR UNEVA, WEST VIRGINL.

This station was established July 8, 1899. As there is no bridge at the place convenient for making measurements, a cable of 600 feet span was stretched across the stream 6 miles northwest of Morgantown, near Uneva, West Virginia. The station is described in WaterSupply Paper No. 36, page 160. During 1900 one measurement was made by E. G. Paul, as follows:

June 25: Gage height, 2.80 feet; discharge, 1,403 second-feet.

Dailg gage height, in feet, of Cheat River near Uneva, West Virginia, for 1900.

\begin{tabular}{|c|c|c|c|c|c|c|c|c|c|c|c|c|c|}
\hline Day. & July. & Aug. & Sept. & Oct. & Nov. & Dec. & Day. & July. & Aug. & Sept. & Oct. & Nov. & Dec. \\
\hline & & & & & 1.6 & & & & & & & & \\
\hline & 2.0 & 3.1 & 21 & 2.0 & 1.6 & 4.0 & & 2.9 & 1.5 & 1.4 & 1.4 & 2.1 & 2.8 \\
\hline & 2.7 & $\begin{array}{l}\text { 2.9 } \\
2.7\end{array}$ & 2.0 & 1.9 & $\begin{array}{l}1.7 \\
1.7\end{array}$ & 4.0 & 19 & $\begin{array}{l}2.9 \\
3.0\end{array}$ & $\begin{array}{l}1.5 \\
1.6\end{array}$ & 1.4 & 1.5 & 2.2 & 2.8 \\
\hline & 2.6 & 2.6 & $\begin{array}{l}1.0 \\
1.6\end{array}$ & 1.7 & 1. 6 & $\begin{array}{l}7.0 \\
7.0\end{array}$ & & $\begin{array}{l}3.0 \\
3.0\end{array}$ & $\begin{array}{l}2.0 \\
2.0\end{array}$ & $\begin{array}{l}1.4 \\
1.3\end{array}$ & $\begin{array}{l}1 . \pm \\
1.3\end{array}$ & $\begin{array}{l}0.0 \\
3.3\end{array}$ & 2.7 \\
\hline & & 2.4 & 1.5 & 1.6 & 2.0 & 7.0 & 22 & 3. 0 & 1.9 & 1.5 & 1.3 & 3.5 & 2.6 \\
\hline & & 2.4 & 1.4 & 1.5 & 2.3 & 6.0 & 23. & 20 & .8 & 1.5 & 1.3 & 3.8 & 3.0 \\
\hline & $\begin{array}{l}8.0 \\
2.9\end{array}$ & 2.3 & $\begin{array}{l}1.4 \\
1.4\end{array}$ & $\begin{array}{l}1.6 \\
1.7\end{array}$ & $\begin{array}{l}2.5 \\
2.4\end{array}$ & $\begin{array}{l}5.0 \\
4.4\end{array}$ & 24 & $\begin{array}{l}3.5 \\
4.8\end{array}$ & $\begin{array}{l}1.8 \\
1.8\end{array}$ & $\begin{array}{l}1.4 \\
1.4\end{array}$ & 2.3 & 4.8 & $\begin{array}{l}3.2 \\
3.3\end{array}$ \\
\hline $10 \ldots$ & 2.9 & 2.0 & 1.4 & 1. 7 & 2.2 & 4.7 & 26 & 5.1 & 1.8 & 1.5 & 2.2 & $\ldots . .$. & 3.3 \\
\hline & 2.8 & $\begin{array}{l}1.0 \\
1.8\end{array}$ & $\begin{array}{l}1.4 \\
1.4\end{array}$ & $\begin{array}{l}1.7 \\
1.7\end{array}$ & $\begin{array}{l}2.0 \\
1.9\end{array}$ & $\begin{array}{l}5.4 \\
3.4\end{array}$ & $28=$ & $\begin{array}{l}0.7 \\
4.9\end{array}$ & $\begin{array}{l}1.6 \\
1.7\end{array}$ & 1.5 & 2.0 & ...... & $\begin{array}{l}3.2 \\
3.1\end{array}$ \\
\hline & 2.6 & 1.7 & 1.3 & 1.6 & 1.9 & 3.2 & 90 & 3.7 & & 1 & 1.8 & 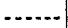 & 3.1 \\
\hline & 2.5 & 1.7 & 1.3 & 1.5 & 1.9 & $\begin{array}{l}3.0 \\
3.0\end{array}$ & & 3.4 & & 1.4 & 17 & & \\
\hline & $\begin{array}{l}2.6 \\
2.6\end{array}$ & $\begin{array}{l}1.7 \\
1.6\end{array}$ & $\begin{array}{l}1.3 \\
1.4\end{array}$ & $\begin{array}{l}1.5 \\
1.4\end{array}$ & $\begin{array}{l}2.0 \\
2.03 \\
3.2\end{array}$ & $\begin{array}{l}8.0 \\
3.0\end{array}$ & & & & & & & \\
\hline
\end{tabular}




\section{NEW RIVER AT RADFORD, VIRGINIA.}

This station, which was established by D. C. Humphreys on August 1, 1898, the gage having been erected by the United States Weather Bureau, is described in Water-Supply Paper No. 36, page 161. On account of the inaccuracies of the Weather Bureau gage, a wire gage was put in February 23, 1900, the zero being on the same level as that of the old gage. The observer is T. M. Brady. Records of measurements for 1899 will be found in Water-Supply Paper No. 36, page 162. During 1900 the following measurements were made by D. C. Humphreys:

February 23: Gage height, 2.55 feet; discharge, 11,681 second-feet.

February 24: Gage height, 2.10 feet; discharge, 8,500 second-feet.

March 30: Gage height, 1.78 feet; discharge, 7,709 second-feet.

June 27: Gage height, 1.62 feet; discharge, 6,749 seconcl-feet.

July 28: Gage height, 1.25 feet; discharge, 5,256 seconc-feet.

August 22: Gage height, 0.00; iischarge, 1,365 second-feet.

December 20: Gage height, 0.70 foot; discharge, 2,975 second-feet.

Daily gage height, in feet, of New River at Radford, Virginia, for 1900.

\begin{tabular}{|c|c|c|c|c|c|c|c|c|c|c|c|c|}
\hline Day. & Jan. & Feb. & Mar. & Apr. & May. & June. & July. & Aug. & Sept. & Oct. & Nov. & Dec. \\
\hline & 0.20 & 0.30 & 5. 85 & 1.90 & 1.20 & 0.80 & 1.00 . & 0.40 & -0.30 & -0.40 & 0.90 & \\
\hline & .20 & .80 & & 1.20 & 1.10 & .70 & .80 & .30 & -.30 & -.40 & .80 & 1.00 \\
\hline$\cdots$ & .20 & $\begin{array}{l}.90 \\
.80\end{array}$ & $\begin{array}{l}3.20 \\
2.10\end{array}$ & $\begin{array}{l}\text { 1. } 20 \\
\text { 1. } 10\end{array}$ & $\begin{array}{l}1.00 \\
1.30\end{array}$ & $\begin{array}{l}1.00 \\
1.00\end{array}$ & .600 & .30 & {$\left[\begin{array}{c}-40 \\
\end{array}\right.$} & .00 & .80 & 1.00 \\
\hline & 20 & 80 & 2.00 & 1.00 & 1.20 & 1.90 & 90 & $\begin{array}{l}80 \\
30\end{array}$ & {$[=: 30$} & 00 & & $\begin{array}{l}1.60 \\
4.50\end{array}$ \\
\hline & 20 & $\sigma_{0}$ & 1. 90 & 1.10 & $\begin{array}{l}1.00 \\
\text { l. }\end{array}$ & 90 & 70 & 00 & .80 & 10 & 00 & 3.00 \\
\hline & 30 & 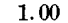 & 18 & 1.00 & 1.0 & 80 & 50 & 00 & 80 & 10 & 1.00 & 2.00 \\
\hline & & & 2.10 & 1.00 & & 90 & 37 & & 70 & ) & 90 & 2.00 \\
\hline & 40 & .90 & 2.20 & & 1.00 & 80 & .34 & .40 & & 20 & 80 & 2.10 \\
\hline & & 100 & ) & 1.00 & 1.30 & 80 & .50 & .60 & 40 & 30 & 80 & 2.00 \\
\hline & 70 & .90 & 2.70 & 1.90 & 1.00 & 70 & .36 & .90 & .30 & 20 & 70 & 1.30 \\
\hline & 然 & 1.20 & 2.60 & 1.80 & 1.00 & 70 & 42 & 00 & .50 & 00 & 60 & 1.40 \\
\hline & & 2.00 & $\begin{array}{c}2.00 \\
0\end{array}$ & 1.20 & 1.00 & .80 & 88 & & & 00 & 60 & 1.00 \\
\hline & 80 & $\begin{array}{l}4.80 \\
\text { 2. }\end{array}$ & 1. ${ }^{7}$ & $\begin{array}{l}1.00 \\
90\end{array}$ & 80 & 1.0 & 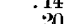 & .00 & 40 & 20 & 00 & 1.00 \\
\hline & & 170 & 140 & 80 & 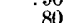 & 1. & 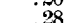 & 60 & & . & 然 & . .90 \\
\hline & .90 & 1.50 & 1. 70 & 80 & .80 & $\begin{array}{l}1.60 \\
1.60\end{array}$ & .26 & $=.80$ & $\begin{array}{l}.80 \\
2.40\end{array}$ & 20 & 年 & 80 \\
\hline & .80 & 1.40 & 1.60 & 70 & 80 & 1.20 & .14 & -.80 & 1.20 & 10 & 40 & .80 \\
\hline & 1.00 & 1.30 & 1.30 & 4.00 & 90 & 2.00 & .02 & -.70 & .50 & .00 & .30 & .70 \\
\hline & & 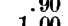 & & 2.60 & & 1.4 & .00 & -.70 & & 00 & 0 & .70 \\
\hline & 1.90 & 1.00 & 4.. 20 & 00 & 1.00 & 1. & .08 & & 40 & & 40 & .60 \\
\hline & $\begin{array}{l}1.09 \\
1.60\end{array}$ & $\begin{array}{l}\text { P. } \\
2.90\end{array}$ & $\begin{array}{l}0.80 \\
2.40\end{array}$ & 9.90 & 90 & $\begin{array}{l}1.00 \\
1.20\end{array}$ & .24 & 00 & .00 & 6.80 & . .000 & .80 \\
\hline & 1.30 & 2.20 & 2.20 & 2.30 & 80 & 1.00 & .42 & .10 & .50 & 23.00 & 40 & 70 \\
\hline & 1.20 & 2.10 & 2.10 & 1.90 & 2.00 & 2.6 & .50 & .20 & .40 & 4.60 & & 1.00 \\
\hline & 1.00 & & 1. & 1. 70 & 1.90 & 1. & .58 & .20 & 30 & & & .90 \\
\hline & .90 & $\begin{array}{l}1.00 \\
2.60\end{array}$ & 240 & $\begin{array}{l}1.60 \\
1.40\end{array}$ & 1.00 & & $\begin{array}{l}86 \\
80 \\
?\end{array}$ & 00 & 0 & & 0 & .70 \\
\hline & .20 & & $\begin{array}{l}2.40 \\
1.90\end{array}$ & $\begin{array}{l}1.40 \\
1.30\end{array}$ & $\begin{array}{l}1.10 \\
1.00\end{array}$ & $\begin{array}{l}1.00 \\
1.80\end{array}$ & .80 & 00 & .80 & $\begin{array}{l}\text { 1. } 20 \\
\text { 1. } 20\end{array}$ & $\begin{array}{l}2.40 \\
1.90\end{array}$ & 70 \\
\hline 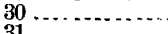 & .20 & 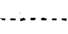 & 1.70 & 1. 20 & 90 & 1.60 & 00 & & -.40 & 1.00 & 1.80 & .60 \\
\hline & & & 1.00 & & 90 & & .50 & & & 1.03 & & \\
\hline
\end{tabular}

GREENBRIER RIVER AT ALDERSON, WEST VIRGINIA.

This station, which was established by C. C. Babb and D. C. Humphreys on August 1, 1895, is described in Water-Supply Paper No. 36, page 163. Records of measurements during 1899 will be found in the Twenty-first Annual Report, Part IV, page 159. During 1900 the following measurements were made by $D$. C. Humphreys:

March 31: Gage height, 4.07 feet; discharge, 5,128 second-feet.

June 29: Gage height, 1.99 feet; discharge, 564 second-feet. 
July 24: Gage height. 1.97 feet; discharge, 493 second-feet.

August 20: Gage height, 1.39 feet; discharge, 148 second-feet.

December 21: Gage height, 2.24 feet; discharge, 834 second-feet.

Daily gage height, in feet, of Greenbrier River at Alderson, West Virginia, for 1900.

\begin{tabular}{|c|c|c|c|c|c|c|c|c|c|c|c|c|}
\hline Day. & Jan. & Feb. & Mar. & Apr. & May. & June. & July. & Aug. & Sept. & Oct. & Nov. & Dec. \\
\hline $\begin{array}{l}26 \\
27 \\
28\end{array} 2 \mathrm{c}$. & $\begin{array}{l}1.90 \\
1.88 \\
1.88 \\
1.88 \\
1.90 \\
1.86 \\
1.85 \\
1.85 \\
1.85 \\
2.05 \\
2.05 \\
2.17 \\
4.18 \\
3.15 \\
2.80 \\
2.53 \\
2.38 \\
2.40 \\
2.65 \\
5.98 \\
5.65 \\
4.33 \\
3.45 \\
3.03 \\
2.75 \\
2.55 \\
2.43 \\
2.25 \\
2.08 \\
2.45 \\
2.05\end{array}$ & $\begin{array}{l}2.15 \\
1.85 \\
1.95 \\
1.95 \\
1.95 \\
2.10 \\
2.40 \\
2.60 \\
3.75 \\
4.25 \\
3.45 \\
3.10 \\
7.24 \\
7.90 \\
5.05 \\
4.00 \\
3.48 \\
3.10 \\
2.65 \\
2.50 \\
.55 \\
4.05 \\
5.40 \\
4.37 \\
3.75 \\
3.53 \\
3.20 \\
2.83\end{array}$ & $\begin{array}{l}3.98 \\
6.81 \\
5.08 \\
4.00 \\
3.58 \\
3.55 \\
4.53 \\
4.90 \\
4.20 \\
3.70 \\
3.45 \\
3.17 \\
3.00 \\
2.90 \\
2.93 \\
2.87 \\
2.85 \\
2.60 \\
2.89 \\
8.12 \\
8.23 \\
5.50 \\
4.50 \\
3.40 \\
4.85 \\
4.60 \\
4.75 \\
4.13 \\
4.05 \\
3.80 \\
4.10\end{array}$ & $\begin{array}{l}3.90 \\
3.48 \\
3.30 \\
3.20 \\
3.08 \\
3.00 \\
.88 \\
2.80 \\
3.00 \\
3.02 \\
2.85 \\
2.65 \\
2.55 \\
2.50 \\
2.37 \\
2.30 \\
2.20 \\
2.40 \\
2.52 \\
3.40 \\
3.55 \\
3.65 \\
3.73 \\
3.45 \\
3.16 \\
2.92 \\
.7 .75 \\
2.20 \\
.45 \\
2.45 \\
2.40\end{array}$ & $\begin{array}{l}2.30 \\
.25 \\
2.18 \\
2.15 \\
2.10 \\
2.05 \\
2.02 \\
2.00 \\
1.95 \\
2.10 \\
2.00 \\
1.95 \\
1.97 \\
1.92 \\
1.85 \\
1.83 \\
1.80 \\
1.77 \\
1.73 \\
1.80 \\
2.90 \\
2.50 \\
2.32 \\
2.20 \\
2.20 \\
2.50 \\
2.45 \\
2.20 \\
2.20 \\
2.40 \\
2.40\end{array}$ & $\begin{array}{l}2.25 \\
2.15 \\
2.10 \\
2.20 \\
2.13 \\
2.05 \\
1.98 \\
1.90 \\
1.90 \\
1.88 \\
1.82 \\
1.75 \\
1.68 \\
1.70 \\
2.05 \\
2.28 \\
3.20 \\
5.23 \\
4.40 \\
3.50 \\
3.00 \\
2.65 \\
2.45 \\
2.25 \\
2.15 \\
2.07 \\
2.05 \\
1.95 \\
1.95 \\
2.00\end{array}$ & $\begin{array}{l}2.75 \\
3.00 \\
2.45 \\
2.40 \\
2.08 \\
2.00 \\
1.90 \\
1.98 \\
1.93 \\
1.78 \\
1.73 \\
1.65 \\
1.63 \\
1.60 \\
1.55 \\
1.52 \\
1.45 \\
1.45 \\
1.45 \\
1.42 \\
1.42 \\
1.48 \\
2.10 \\
2.20 \\
2.27 \\
2.44 \\
3.97 \\
3.90 \\
2.90 \\
2.50 \\
2.48\end{array}$ & $\begin{array}{l}2.45 \\
2.15 \\
2.00 \\
1.90 \\
1.80 \\
1.70 \\
1.42 \\
1.60 \\
1.57 \\
1.55 \\
1.52 \\
1.48 \\
1.45 \\
1.40 \\
1.40 \\
1.40 \\
1.35 \\
1.37 \\
1.40 \\
1.40 \\
1.40 \\
1.50 \\
1.40 \\
1.45 \\
1.40 \\
1.50 \\
1.50 \\
1.55 \\
1.60 \\
1.50\end{array}$ & $\begin{array}{l}1.55 \\
1.53 \\
1.48 \\
1.45 \\
1.40 \\
1.38 \\
1.35 \\
1.00 \\
1.28 \\
1.27 \\
1.25 \\
1.23 \\
1.20 \\
1.20 \\
1.31 \\
1.88 \\
1.65 \\
1.50 \\
1.45 \\
1.40 \\
1.38 \\
1.43 \\
1.50 \\
1.63 \\
1.50 \\
1.53 \\
1.45 \\
1.40 \\
1.45 \\
1.40\end{array}$ & $\begin{array}{l}1.40 \\
1.50 \\
1.45 \\
1.43 \\
1.40 \\
1.38 \\
1.37 \\
1.35 \\
1.38 \\
1.37 \\
1.35 \\
1.35 \\
1.33 \\
1.45 \\
1.70 \\
1.70 \\
1.60 \\
1.55 \\
1.50 \\
1.45 \\
1.45 \\
1.43 \\
2.47 \\
3.68 \\
2.60 \\
2.45 \\
2.25 \\
2.00 \\
1.75 \\
1.70 \\
1.63\end{array}$ & $\begin{array}{r}1.45 \\
1.58 \\
1.60 \\
3.20 \\
2.75 \\
2.25 \\
2.05 \\
1.93 \\
1.90 \\
1.80 \\
1.72 \\
1.75 \\
1.75 \\
1.85 \\
1.80 \\
1.78 \\
1.75 \\
1.68 \\
1.65 \\
1.60 \\
1.72 \\
2.43 \\
3.38 \\
3.68 \\
18.23 \\
9.30 \\
5.03 \\
4.00 \\
3.37\end{array}$ & $\begin{array}{l}3.00 \\
2.75 \\
2.58 \\
3.48 \\
7.00 \\
5.15 \\
4.00 \\
3.55 \\
3.40 \\
3.40 \\
3.15 \\
2.92 \\
2.76 \\
2.65 \\
2.55 \\
2.45 \\
2.30 \\
2.25 \\
2.25 \\
2.20 \\
2.23 \\
2.20 \\
2.08 \\
2.05 \\
2.18 \\
2.23 \\
2.18 \\
2.13 \\
2.12 \\
2.38 \\
2.35\end{array}$ \\
\hline
\end{tabular}

NORTH FORK OF NEW RIVER AT WEAVERSFORD, NORTH CAROLINA.

During the summer of 1900 a special investigation of the hydrographic conditions of the southern Appalachian region was made by the United States Geological Survey. Temporary stations were established on several of the largest rivers, among these being the North Fork and the South Fork of New River. A station was also established on New River near Oldtown, Virginia. The regular station on New River, which is at Fayette, West Virginia, has been continued. Descriptions of these temporary stations and the gage heights obtained are given on the following pages.

The station at Weaversford was established July 27, 1900, by Cleveland Ȧbbe, jr., and N. C. Curtis. The nearest railroad station is at North Wilkesboro, 40 miles distant, and the Weaversford post-office is a fourth of a mile from the gaging station, which can only be reached by private conveyance. The gage rod is 12.6 feet long, and is divided into feet and tenths. It is nailed to the downstream vertical timber of the forebay of Dixon's mill. The discharge measurements are made by wading at a comparatively shallow ford, not much used and not on a public highway, located 400 yards below the house of Mr. Dixon, the owner of the mill. The initial point of sounding is on the right bank, at the outer edge of a fence post opposite the ford where measurements are made. The banks are high and have been overflowed only 
once, viz, in 1878. The bed of the stream is rocky and gravelly, and is constant in form. The observer is C. L. Nelson, post-office address Weaversford, Ashe County, North Carolina. The gage heights for 1900 will be published next year: During 1900 the following measurements were made by N. C. Curtis and Cleveland Abbe, jr. :

July 2s: Gage height, 0.60 foot; discharge, 536 second-feet.

October 27: Gage height, 0.90 foot; discharge, 708 second-feet.

SOUTH FORK OF NEW RIVER AT NEW RIVER, NORTH CAROLINA.

This station was established' July 28, 1900, by Cleyeland Abbe, jr., and $\dot{N}$. C. Curtis. The nearest railroad station is North Wilkesboro, 30 miles distant, and the gaging station can only be reached by private conveyance. The discharge measurements are made by wading across a ford a half mile above the confluence of the North and South forks of New River and about 1 mile downstream from the gage at Warden's store. The gage is a wire cord running over a bolt driven into a locust tree, and reads on a horizontal scale divided into feet and tenths. The pointer or index on the gage wire is 10.55 feet from the extreme tip of the double window-sash weights which are attached. When the latter rest on the bottom, the index stands opposite 1 foot on the scale, which is read direct. The initial point of sounding is a notch on the stream side of the second small poplar on the left of the road going toward the stream and opposite the ford. The channel is straight, the current fairly swift, and the banks are low and seldom overflow. The bed of the stream is rocky, with bowlders and cobbles. The drainage area at this station is 326.5 square miles. The observer is F. R. Warden, a storekeeper located about 75 yards downstream from the gage. During 1900 the following measurements were made by N. C. Curtis and Cleveland Abbe, jr.:

July 28: Gage height, 2.7 feet; discharge, 751 second-feet.

October 28: Gage height, 2.6 feet; discharge, 1,635 second-feet.

Daily gage height, in feet, of South Fork of New River at New River, North Carolina, for 1900 .

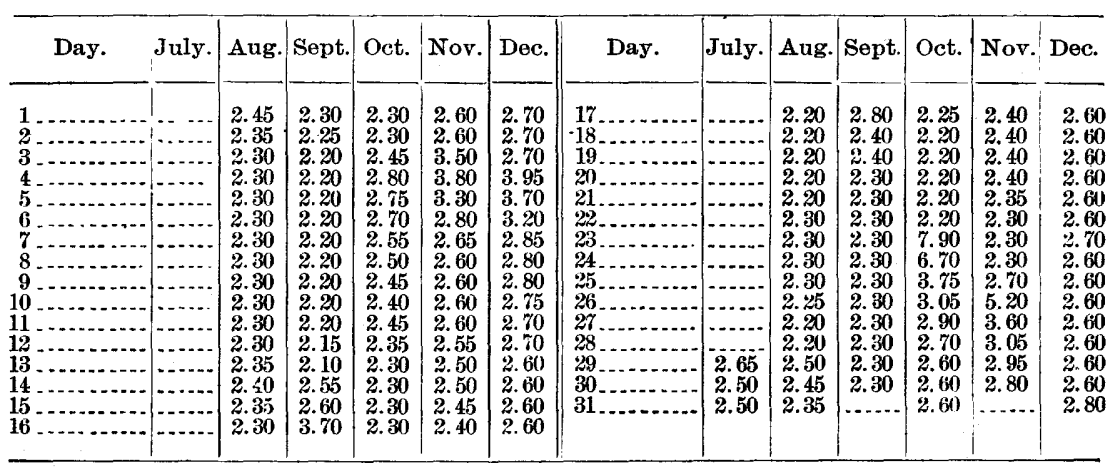




\section{NEW RIVER NEAR OLDTOWN, VIRGINIA.}

This station, which was established by Cleveland Abbe, jr., and N. C. Curtis, July 31,1900 , is located about 2 miles west of Oldtown, and ean only be reached by private conveyance. Oldtown is 30 miles from the railroad at Mount Airy, and 9 miles from a branch of the Norfolk and Western Railway. The wire gage is suspended from an overhanging tree on the left bank, 50 yards upstream from the ferry. The horizontal scale is so placed that the zero mark is next to the bank. The distance from the index on the wire to the bottom of the weight is 16.1 feet. The initial point of sounding is on the right bank, and is a notch cut in the wooden upright of the beam supporting the north end of the ferry cable. The channel above and below the station is straight and the current is fairly swift. The right bank is rather low and is subject to overflow. The left bank is rarely submerged in flood. The bed of the stream is rocky and sandy. The observer is Joshua Austin, a farmer of Oldtown. During 1900 the following measurements were made by N. C. Curtis and Cleveland Abbe, jr.:

July 31: Gage height, 6.6 feet; discharge, 1,541 second-feet.

October 29: Gage height, 6.3 feet; discharge, 2,293 second-feet.

Daily gage height, in feet, of New River near Oldtown, Virginia, for 1900.

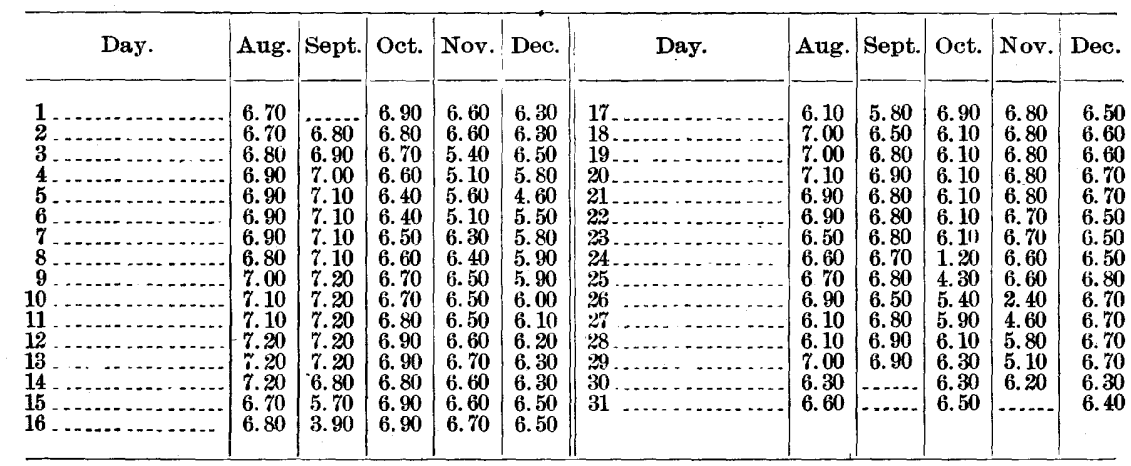

NEW RIVER AT FAYETTE, WEST VIRGINIA.

This station, which was established July 29, 1895, is just above the mouth of Wolf Creek, on the one-span highway bridge at Fayette, West Virginia. It is described in Water-Supply Paper No. 36, page 164. Records of measurements for 1899 will be found in the Twentyfirst Annual Report, Part IV, page 157. During 1900 the following measurements were made by D. C. Humphreys:

March 31: Gage height, 8.49 feet; discharge, 17,387 second-feet.

June 29: Gage height, 5.58 feet; discharge, 11,436 second-feet.

July 25: Gage height, 2.47 feet; discharge, 4,625 second-feet.

August 20: Gage height, 0.55 foot; discharge, 2,275 second-feet.

December 21: Gage height, 3.40 feet; discharge, 5,915 second-feet.

IRR $48-01-6$ 
Daily gage height, in feet, of New River at Fayette, West Virginia, for 1900.

\begin{tabular}{|c|c|c|c|c|c|c|c|c|c|c|c|c|}
\hline & Jan. & Feb. & Mar. & Apr. & May. & June. & July. & Aug. & Sept. & Oct. & Nov. & Dec. \\
\hline 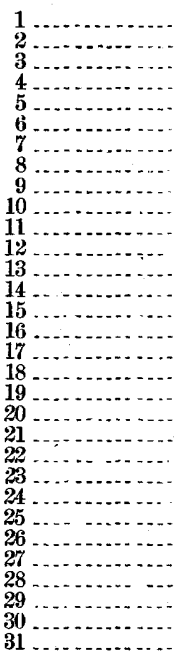 & $\begin{array}{l}2.95 \\
3.20 \\
3.40 \\
3.10 \\
3.10 \\
3.00 \\
3.05 \\
3.10 \\
3.40 \\
3.60 \\
4.10 \\
4.44 \\
6.20 \\
5.45 \\
5.30 \\
5.00 \\
4.70 \\
4.40 \\
4.30 \\
5.45 \\
8.75 \\
6.40 \\
4.40 \\
3.25 \\
3.60 \\
3.35 \\
3.50 \\
3.60 \\
3.75 \\
4.20 \\
4.05\end{array}$ & \begin{tabular}{|r}
3.95 \\
3.60 \\
3.55 \\
3.50 \\
3.40 \\
3.45 \\
3.30 \\
3.05 \\
3.00 \\
3.20 \\
3.40 \\
4.05 \\
4.20 \\
11.25 \\
9.60 \\
7.05 \\
3.40 \\
3.55 \\
4.10 \\
4.05 \\
5.10 \\
5.40 \\
7.30 \\
6.55 \\
5.60 \\
6.10 \\
5.30 \\
4.20 \\
...- \\
\end{tabular} & $\begin{array}{r}7.80 \\
12.50 \\
8.15 \\
6.40 \\
5.55 \\
4.05 \\
4.10 \\
3.80 \\
3.50 \\
3.45 \\
3.90 \\
4.05 \\
4.00 \\
4.00 \\
5.10 \\
5.75 \\
5.85 \\
6.20 \\
7.85 \\
10.40 \\
13.60 \\
12.30 \\
9.90 \\
7.45 \\
5.95 \\
5.15 \\
4.90 \\
7.50 \\
9.65 \\
8.60 \\
8.50\end{array}$ & $\begin{array}{r}8.30 \\
7.50 \\
6.90 \\
6.50 \\
6.20 \\
5.70 \\
5.40 \\
5.00 \\
4.85 \\
4.95 \\
4.75 \\
4.40 \\
4.25 \\
4.30 \\
4.20 \\
3.80 \\
3.60 \\
3.40 \\
3.80 \\
10.20 \\
8.50 \\
8.00 \\
9.80 \\
9.30 \\
7.85 \\
6.85 \\
6.10 \\
5.50 \\
5.00 \\
4.60 \\
\cdots \cdots\end{array}$ & $\begin{array}{l}4.50 \\
4.40 \\
4.10 \\
4.00 \\
4.00 \\
3.95 \\
3.85 \\
3.85 \\
3.90 \\
4.00 \\
4.50 \\
4.60 \\
4.25 \\
3.85 \\
3.55 \\
3.25 \\
3.15 \\
2.90 \\
4.50 \\
4.45 \\
4.10 \\
4.60 \\
4.10 \\
3.50 \\
4.00 \\
6.55 \\
6.05 \\
5.30 \\
4.60 \\
4.25 \\
4.90\end{array}$ & \begin{tabular}{|r|}
4.30 \\
3.60 \\
3.30 \\
3.00 \\
4.00 \\
3.50 \\
3.30 \\
3.00 \\
2.65 \\
2.50 \\
2.40 \\
2.20 \\
3.45 \\
3.60 \\
3.50 \\
8.20 \\
10.40 \\
11.00 \\
10.50 \\
8.50 \\
6.80 \\
6.30 \\
6.00 \\
5.80 \\
5.60 \\
5.25 \\
5.00 \\
4.70 \\
5.50 \\
6.75 \\
$\cdots$
\end{tabular} & $\begin{array}{l}6.60 \\
6.15 \\
5.30 \\
4.00 \\
3.10 \\
2.70 \\
2.90 \\
2.10 \\
1.80 \\
1.45 \\
1.10 \\
.90 \\
.80 \\
.70 \\
.60 \\
.60 \\
.60 \\
.50 \\
.80 \\
.90 \\
.90 \\
.75 \\
.50 \\
2.10 \\
2.70 \\
2.90 \\
5.00 \\
6.20 \\
6.50 \\
5.00 \\
3.80\end{array}$ & $\begin{array}{r}3.00 \\
.20 \\
1.40 \\
1.00 \\
.70 \\
.50 \\
.25 \\
.10 \\
.10 \\
.00 \\
.90 \\
.60 \\
.30 \\
.20 \\
.10 \\
.10 \\
.20 \\
.20 \\
.10 \\
.30 \\
.30 \\
.40 \\
.40 \\
.50 \\
.70 \\
1.00 \\
1.15 \\
1.30 \\
1.50 \\
2.00 \\
1.40\end{array}$ & $\begin{array}{r}0.90 \\
.90 \\
.90 \\
.80 \\
.80 \\
.70 \\
.70 \\
.70 \\
.60 \\
.75 \\
.80 \\
.85 \\
.75 \\
.90 \\
.80 \\
.10 \\
6.15 \\
7.80 \\
6.00 \\
5.40 \\
5.05 \\
4.60 \\
4.30 \\
2.85 \\
2.50 \\
2.05 \\
1.40 \\
1.25 \\
1.15 \\
1.90 \\
. . .\end{array}$ & $\begin{array}{r}1.10 \\
.95 \\
.80 \\
.80 \\
.75 \\
1.10 \\
1.10 \\
1.45 \\
1.70 \\
1.80 \\
1.60 \\
1.35 \\
1.40 \\
2.05 \\
2.25 \\
2.00 \\
1.85 \\
3.05 \\
3.20 \\
2.95 \\
3.15 \\
3.15 \\
2.90 \\
16.05 \\
18.10 \\
13.30 \\
10.00 \\
6.50 \\
5.00 \\
4.75 \\
4.00\end{array}$ & \begin{tabular}{|c}
3.50 \\
3.70 \\
3.00 \\
2.80 \\
2.65 \\
2.90 \\
3.25 \\
3.40 \\
3.80 \\
4.00 \\
3.75 \\
3.60 \\
3.45 \\
3.35 \\
3.10 \\
3.00 \\
2.70 \\
2.50 \\
2.40 \\
2.30 \\
3.10 \\
4.40 \\
5.80 \\
6.60 \\
\hdashline 2.00 \\
25.00 \\
$(a)$ \\
$(a)$ \\
$(a)$ \\
$\ldots$ \\
$\ldots$
\end{tabular} & $\begin{array}{l}(a) \\
(a) \\
(a) \\
(a) \\
(a) \\
(a) \\
(a) \\
(a) \\
(a) \\
(a) \\
(a) \\
(a) \\
(a) \\
(a) \\
(a) \\
(a) \\
(a) \\
(a) \\
(a) \\
(a) \\
(a) \\
(a) \\
(a) \\
2.50 \\
2.80 \\
3.00 \\
3.20 \\
3.50 \\
3.90 \\
3.90 \\
4.10\end{array}$ \\
\hline
\end{tabular}

a Gage broken; no record.

\section{SOUTH FORK OF HOLSTON RIVER AT BLUFF CITY, TENNESSEE.}

This station was originally established by the United States Weather Bureau at the highway bridge at Bluff City. Readings were begun July 17, 1900, by the United States Geological Survey, in connection with the general hydrographic investigation of the southern Appalachian region. The gage is a 4-inch by 8 -inch timber bolted to the downstream side of the stone pier. The initial point of sounding is on the north end of the bridge, downstream side. The channel is straight for about 500 feet above and below the bridge, and the current is swift. The north bank is high, but the south bank is subject to overflow at the bridge. The bed is rocky and constant in section. The drainage area is 828.1 square miles. O. V. Cox is the observer. During 1900 the following measurements were made by E. W. Myers and L. V. Branch:

July 17: Gage height, 0.25 foot; discharge, 378 second-feet.

August 16: Gage height, 0.25 foot; discharge, 329 second-feet.

September 25: Gage height, 1.15 feet; discharge, 791 second-feet.

November 8: Gage height, 0.90 foot; discharge, 681 second-feet.

December 27: Gage height, 0.60 foot; discharge, 392 second-feet. 
Daily gage height, in feet, of South Fork of Holston River at Bluff City, Tennessee, for 1900 .

\begin{tabular}{r|r|r|r|r|r|r||r|r|r|r|r|r|r|r}
\hline Day. & July. & Aug. & Sept. & Oct. & Nov. & Dec. & Day. & July. Aug. & Sept. & Oct. & Nov. & Dec. \\
\hline 1 & & & & & & & \\
\hline
\end{tabular}

\section{WATAUGA RIVER AT BUTLER, TENNESSEE.}

In connection with the general hydrographic investigation of the southern Appalachian region, stations were established on Watauga River and on Roan Creek at Butler, Tennessee; also on Elk Creek at Lineback, Tennessee. Descriptions of these stations and records of the gage heights and discharge measurements are given on the following pages. The station on Watauga River at Butler is about 100 yards below the mouth of Roan Creek. It was established August 14,1900 . The gage rod, which is graduated to feet and tenths, is nailed to a tree on the right bank. Measurements are made from the highway bridge. The initial point of sounding is at the downstream end of the guard rail. The channel is straight above and below the station, and the current is swift. The banks are high, and the bed is sandy and rocky. The drainage area is 261 square miles. The observer is Edgar L. Shull. During 1900 the following measurements were made by E. W. Myers and L. V. Branch:

July 30: Gage height, 1.37 feet; discharge, 434 second-feet.

August 7: Gage height, 0.90 foot; discharge, 214 second-feet.

August 17: Gage height, 0.84 foot; discharge, 166 second-feet.

October 6: Gage height, 1.12 feet; discharge, 238 second-feet.

November 7: Gage height, 2.20 feet; discharge, 591 second-feet.

December 28: Gage height, 1.40 feet; discharge, 311 second-feet.

Daily gage height, in feet, of Watauga River at Butler, Tennessee, for 1900.

\begin{tabular}{|c|c|c|c|c|c|c|c|c|c|c|c|}
\hline Day. & Ang. & Sept. & Oct. & Nov. & Dec. & Day. & Aug. & Sept. & Oct. & Nor. & Dec. \\
\hline $\begin{array}{l}1 \\
2 \\
3 \\
4 \\
5 \\
6\end{array}$ & \begin{tabular}{|c}
1.30 \\
.80 \\
.70
\end{tabular} & $\begin{array}{r}0.90 \\
.90 \\
.90 \\
.90 \\
.90 \\
.90 \\
.80 \\
.80 \\
.80 \\
.80 \\
.80 \\
.80 \\
.80 \\
1.70 \\
1.70 \\
3.10\end{array}$ & $\begin{array}{r}0.90 \\
\because .90 \\
.90 \\
.90 \\
.90 \\
.90 \\
.90 \\
.90 \\
.90 \\
.90 \\
.90 \\
.80 \\
.80 \\
.90 \\
.80 \\
.70\end{array}$ & $\begin{array}{l}5.60 \\
5.00 \\
2.30 \\
2.10 \\
2.50 \\
2.30 \\
2.00 \\
2.00 \\
1.90 \\
1.90 \\
1.90 \\
1.80 \\
1.60 \\
1.50 \\
1.50 \\
1.50\end{array}$ & $\begin{array}{l}2.00 \\
2.40 \\
2.40 \\
5.00 \\
4.00 \\
3.50 \\
3.00 \\
2.50 \\
2.10 \\
1.90 \\
1.50 \\
1.50 \\
1.50 \\
1.50 \\
1.50 \\
1.50\end{array}$ & $\begin{array}{l}17 \\
18 \\
19 \\
20 \\
21 \\
22 \\
23 \\
24 \\
25 \\
26 \\
26 \\
28 \\
28 \\
29 \\
30 \\
31\end{array}$ & $\begin{array}{r}0.90 \\
.80 \\
.80 \\
1.10 \\
1.60 \\
1.30 \\
1.20 \\
.90 \\
.90 \\
.90 \\
.90 \\
.80 \\
1.90 \\
1.40\end{array}$ & $\begin{array}{r}4.50 \\
4.00 \\
3.20 \\
2.70 \\
1.10 \\
1.00 \\
1.10 \\
.90 \\
.90 \\
.90 \\
.90 \\
.90 \\
.90 \\
.90\end{array}$ & $\begin{array}{r}0.70 \\
.70 \\
.70 \\
.70 \\
.70 \\
.70 \\
15.00 \\
9.00 \\
4.50 \\
2.50 \\
2.00 \\
4.50 \\
4.00 \\
4.00 \\
3.20\end{array}$ & $\begin{array}{l}1.50 \\
1.50 \\
1.40 \\
1.40 \\
1.40 \\
1.40 \\
1.40 \\
1.40 \\
1.40 \\
5.40 \\
4.00 \\
3.00 \\
3.00 \\
2.40\end{array}$ & $\begin{array}{l}1.50 \\
1.50 \\
1.50 \\
1.50 \\
1.50 \\
1.50 \\
1.50 \\
1.50 \\
1.50 \\
1.50 \\
1.50 \\
1.50 \\
1.50 \\
1.50 \\
1.50\end{array}$ \\
\hline
\end{tabular}




\section{ROAN CREEK AT BUTLER, TENNESSEE.}

This station was established August 8, 1900. The gage is a vertical rod nailed to a tree on the left bank of the stream, at Cole \& Scott's gristmill, about a half mile above the mouth of the creek. Measurements are made from the highway bridge at the mouth of the creek, the initial point of sounding being on the right bank, at the end of the upstream guard rail. The left bank is low and is subject to overflow. The bed is composed of sand and mud. The drainage area is 163.6 square miles. The observer is W. N. Bridges, of Butler.

During 1900 the following measurements were made by $\mathbf{E}$. W. Myers and L. V. Branch:

July 30: Gage height, 1:47 feet; discharge, 137 second-feet.

August 7: Gage height, 1.02 feet; discharge, 65 second-feet.

August 17: Gage height, 0.85 foot; discharge, 58 second-feet.

October 6: Gage height, 0.86 foot; discharge, 52 second-feet.

Novernber 7: Gage height, 1.50 feet; discharge, 171 second-feet.

December 28: Gage height, 1.20 feet; discharge, 82 second-feet.

Daily gage height, in feet, of Roan Creek at Butler, Tennessee, for 1900.

\begin{tabular}{|c|c|c|c|c|c|c|c|c|c|c|c|}
\hline Day. & Aug. & Sept. & Oct. & Day. & Ang. & Sept. & Oct. & Day. & Aug. & Sept. & Oct. \\
\hline $\begin{array}{r}1 \\
2 \\
3 \\
4 \\
5 \\
6 \\
7 \\
8\end{array}$ & $\begin{array}{r}0.90 \\
.72 \\
.82 \\
.78\end{array}$ & $\begin{array}{l}0.95 \\
1.00 \\
.83 \\
.88 \\
.83 \\
.81 \\
.80 \\
.76 \\
.80 \\
.75 \\
.75\end{array}$ & $\begin{array}{l}. .00 \\
.85 \\
.85 \\
.85 \\
.80 \\
.86 \\
.80 \\
.83 \\
.89 \\
.88 \\
.83\end{array}$ & $\begin{array}{l}12 \\
13 \\
14 \\
15 \\
16 \\
17 \\
18 \\
19 \\
20 \\
21 \\
21\end{array}$ & $\begin{array}{r}0.78 \\
.85 \\
1.20 \\
.93 \\
.86 \\
.84 \\
.85 \\
.80 \\
.82 \\
1.05 \\
1.71\end{array}$ & $\begin{array}{r}0.73 \\
.75 \\
1.00 \\
1.65 \\
2.50 \\
1.30 \\
1.05 \\
1.00 \\
.93 \\
.92 \\
.95\end{array}$ & $\begin{array}{l}0.87 \\
.90 \\
.85 \\
.88 \\
.82 \\
.80 \\
.80 \\
.80 \\
.81 \\
.78 \\
.80\end{array}$ & $\begin{array}{l}23 \\
24 \\
25 \\
26 \\
27 \\
28 \\
29 \\
30 \\
31\end{array}$ & $\begin{array}{r}1.27 \\
1.00 \\
.90 \\
.90 \\
.84 \\
.86 \\
.91 \\
1.32 \\
1.05\end{array}$ & $\begin{array}{r}1.20 \\
1.25 \\
1.05 \\
.95 \\
.98 \\
.91 \\
.95 \\
1.30 \\
\hdashline . .\end{array}$ & 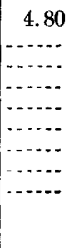 \\
\hline
\end{tabular}

ELK CREEK AT LINEBACK, TENNESSEE.

This station was established August 8, 1900. The gage rod is nailed to a tree on the left bank, 100 yards below the Lineback post-office. Gagings are made by wading. The banks are low and are subject to overflow. The channel is straight and the current is swift. The drainage area is 80.4 square miles. The observer is Dove Lineback, of Lineback, Tennessee. During 1900 the following measurements were made by E. W. Myers and L. V. Branch:

August 9: Gage height, 3.5 feet; discharge, 70 second-feet.

August 17: Gage height, 3.5 feet; discharge, 56 second-feet.

October 6: Gage height, 3.5 feet; discharge, 53 second-feet. 
Daily gage height, in feet, of Elk Creek at Lineback, Tennessee, for 1900.

\begin{tabular}{|c|c|c|c|c|c|c|c|c|c|c|c|}
\hline Day. & Ang. & Sept. & Oct. & Nov. & Dec. & Day. & Aug. & Sept. & Oct. & Nov. & Dec. \\
\hline $\begin{array}{r}1 \\
2 \\
2 \\
3\end{array} 4$ & \begin{tabular}{l}
0 \\
\hdashline 3.50 \\
3.50 \\
3.50 \\
3.50 \\
3.50 \\
3.50 \\
3.70 \\
3.60 \\
3.50
\end{tabular} & $\begin{array}{l}3.60 \\
3.50 \\
3.50 \\
3.50 \\
3.40 \\
3.50 \\
3.50 \\
3.40 \\
3.40 \\
3.40 \\
3.30 \\
3.30 \\
3.40 \\
3.80 \\
4.30 \\
4.30\end{array}$ & $\begin{array}{l}3.40 \\
3.40 \\
3.40 \\
3.60 \\
3.60 \\
3.50 \\
3.50 \\
3.50 \\
3.50 \\
3.40 \\
3.50 \\
3.60 \\
3.50 \\
3.50 \\
3.40 \\
3.40\end{array}$ & $\begin{array}{l}4.00 \\
3.90 \\
5.30 \\
5.60 \\
5.30 \\
4.50 \\
4.30 \\
4.20 \\
4.00 \\
4.00 \\
4.00 \\
4.00 \\
4.00 \\
4.00 \\
3.90 \\
3.90\end{array}$ & $\begin{array}{l}5.30 \\
5.30 \\
5.30 \\
5.80 \\
4.80 \\
4.60 \\
4.50 \\
4.40 \\
4.30 \\
4.20 \\
4.40 \\
4.40 \\
4.30 \\
4.20 \\
4.00 \\
4.00\end{array}$ & $\begin{array}{l}17 \ldots \\
18 \ldots \\
19 \ldots \\
20 \ldots \\
21 \ldots \\
22 \ldots \\
23 \ldots \\
24 \ldots \\
25 \ldots \\
26 \ldots \\
27 \ldots \\
28 \ldots \\
29 \ldots \\
30 \ldots \\
31 \ldots\end{array}$ & $\begin{array}{l}3.50 \\
3.50 \\
3.40 \\
3.50 \\
4.00 \\
3.90 \\
3.40 \\
3.40 \\
3.40 \\
3.40 \\
3.40 \\
3.50 \\
3.50 \\
4.00 \\
3.90\end{array}$ & $\begin{array}{l}4.00 \\
3.80 \\
3.70 \\
3.60 \\
3.60 \\
3.60 \\
3.60 \\
3.60 \\
3.60 \\
3.50 \\
3.50 \\
3.50 \\
3.40 \\
3.40\end{array}$ & $\begin{array}{r}3.40 \\
3.40 \\
3.30 \\
3.30 \\
3.30 \\
3.30 \\
11.00 \\
5.60 \\
5.50 \\
5.40 \\
5.30 \\
4.70 \\
4.50 \\
4.00 \\
4.00\end{array}$ & $\begin{array}{l}3.90 \\
3.80 \\
3.80 \\
3.80 \\
3.80 \\
3.80 \\
3.80 \\
3.90 \\
3.90 \\
6.30 \\
5.70 \\
4.70 \\
5.50 \\
3.60\end{array}$ & $\begin{array}{l}4.00 \\
4.00 \\
4.30 \\
4.20 \\
4.10 \\
4.00 \\
4.00 \\
4.00 \\
4.20 \\
4.30 \\
4.20 \\
4.10 \\
4.00 \\
4.20 \\
4.40\end{array}$ \\
\hline
\end{tabular}

\section{NOLICHUCKY RIVER NEAR CHUCKY VALLEY, TENNESSEE.}

This station was established September 6, 1900, at the highway bridge 1 mile above Chucky Valley, as an aid in the general hydrographic investigations of the southern Appalachian region made during the summer of 1900 . The wire gage is suspended from the upstream side of the bridge, and is referred to a scale on the guard rail. The initial point of sounding is at the end of the lower guard rail on the left bank, downstream side. The banks are high, the current is sluggish, and the bed is sandy. The stream is straight above and below the station. The drainage area is 817 square miles. The observer is Byrd Bayless, Chucky Valley, Tennessee. During 1900 the following measurements were made by L. V. Branch and E. W. Myers:

September 5: Gage height, 2 feet; discharge, 302 second-feet.

September 20: Gage height, 2.18 feet; discharge, 442 second-feet.

October 15: Gage height, 2 feet; discharge, 378 second-feet.

November 10: Gage height, 2.90 feet; discharge, 919 second-feet.

Daily gage height, in feet, of Nolichucky River near Chucky Valley, Tennessee, for 1900.

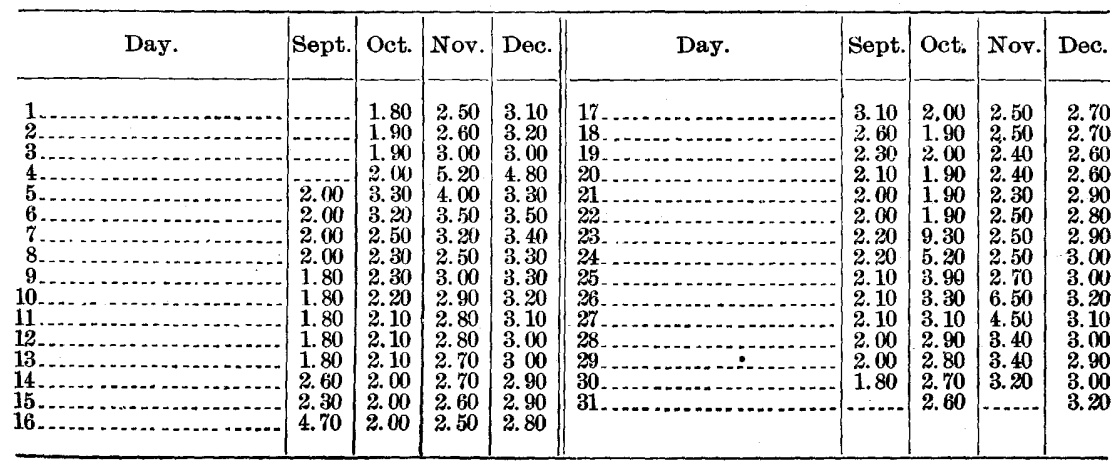


FRENCH BROAD RIVER NEAR ASHEVILLE, NORTH CAROLINA.

This station, which was established by C. C. Babb in September, 1895 , is located at the Bingham School iron highway bridge, 3 miles west of Asheville, and is reached by electric car from that place. It is described in Water-Supply Paper No. 36, page 165. Records of measurements for 1899 will be found in the Twenty-first Annual Report, Part IV, page 160. During 1900 the following measurements were made by E. W. Myers, R. E. Shuford, and others:

Discharge measurements of French Broad River near Asheville, North Carolina.

\begin{tabular}{|c|c|c|c|c|c|}
\hline Date. & $\begin{array}{c}\text { Gage } \\
\text { height. }\end{array}$ & Discharge. & Date. & $\begin{array}{c}\text { Gage } \\
\text { height. }\end{array}$ & Discharge. \\
\hline 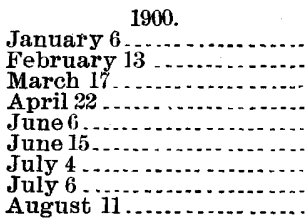 & $\begin{array}{l}\text { Feet. } \\
\quad .52 \\
7.95 \\
\quad 4.20 \\
\text { 6. } \\
\text { 3. } 30 \\
\text { 3.60 } \\
3.75 \\
\quad 4.05 \\
\text { 3.10 }\end{array}$ & $\begin{array}{r}\text { Sec.-ft. } \\
1,368 \\
16,967 \\
4,982 \\
13,069 \\
2,848 \\
2,258 \\
4,273 \\
\mathbf{3}, 112 \\
1,294\end{array}$ & 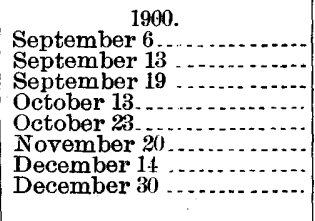 & $\begin{aligned} \text { Feet. } \\
\text { 3.00 } \\
2.82 \\
3.24 \\
3.00 \\
\text { 8. } 20 \\
\text { 3. } 20 \\
\text { 3. } 50 \\
\text { 3. } 78\end{aligned}$ & $\begin{array}{r}\text { Sec.-ft. } \\
1,002 \\
710 \\
1,452 \\
997 \\
16,575 \\
1,414 \\
1,638 \\
2,135\end{array}$ \\
\hline
\end{tabular}

Daily gage height, in feet, of French Broad River near Ashevilile, North Carolina, for 1900 .

\begin{tabular}{|c|c|c|c|c|c|c|c|c|c|c|c|c|}
\hline Day. & Jan. & Feb. & Mar. & Apr. & May. & June. & July. & Aug. & Sept. & Oct. & Nov. & Dec. \\
\hline $\begin{array}{r}1 \\
2 \\
3\end{array}$ & $\begin{array}{l}2.67 \\
2.35 \\
2.25 \\
2.30 \\
2.35 \\
.47 \\
. .90 \\
2.60 \\
2.45 \\
2.33 \\
2.80 \\
4.30 \\
4.25 \\
3.93 \\
3.80 \\
4.45 \\
4.10 \\
3.80 \\
3.60 \\
4.20 \\
4.10 \\
4.00 \\
3.80 \\
3.75 \\
3.65 \\
3.45 \\
3.30 \\
3.20 \\
2.95 \\
2.90 \\
2.85\end{array}$ & $\begin{array}{l}2.83 \\
2.65 \\
2.63 \\
2.80 \\
3.10 \\
3.20 \\
3.50 \\
3.60 \\
3.70 \\
3.75 \\
3.00 \\
3.80 \\
7.95 \\
7.05 \\
6.55 \\
5.87 \\
4.95 \\
4.30 \\
3.47 \\
3.40 \\
3.80 \\
4.90 \\
4.70 \\
4.60 \\
4.40 \\
3.50 \\
3.60 \\
3.80 \\
\ldots \ldots . . . \\
\ldots . . . .\end{array}$ & $\begin{array}{l}7.40 \\
6.70 \\
6.10 \\
5.80 \\
4.70 \\
3.75 \\
3.80 \\
4.90 \\
4.70 \\
4.30 \\
4.10 \\
3.80 \\
3.60 \\
3.45 \\
3.37 \\
3.40 \\
3.50 \\
3.70 \\
3.75 \\
4.40 \\
4.20 \\
4.10 \\
3.70 \\
3.60 \\
3.40 \\
4.30 \\
4.00 \\
3.85 \\
3.80 \\
3.60 \\
3.53\end{array}$ & $\begin{array}{l}3.40 \\
3.33 \\
3.40 \\
3.73 \\
3.60 \\
3.20 \\
3.15 \\
3.10 \\
3.07 \\
3.05 \\
3.20 \\
3.40 \\
3.30 \\
3.25 \\
3.00 \\
3.95 \\
4.30 \\
5.60 \\
5.75 \\
5.80 \\
6.35 \\
7.40 \\
5.10 \\
4.60 \\
4.55 \\
4.43 \\
4.20 \\
3.90 \\
3.70 \\
3.60\end{array}$ & $\begin{array}{l}4.53 \\
4.47 \\
3.45 \\
3.35 \\
3.27 \\
3.20 \\
3.17 \\
3.15 \\
3.20 \\
3.15 \\
3.10 \\
3.00 \\
3.00 \\
2.90 \\
.85 \\
2.87 \\
2.85 \\
2.83 \\
2.80 \\
2.77 \\
2.65 \\
2.47 \\
.30 \\
. .60 \\
3.05 \\
3.10 \\
3.00 \\
2.80 \\
2.73 \\
2.67 \\
2.80\end{array}$ & $\begin{array}{l}3.05 \\
3.10 \\
3.03 \\
3.05 \\
3.55 \\
3.80 \\
4.20 \\
405 \\
4.00 \\
3.80 \\
3.70 \\
3.40 \\
3.45 \\
3.30 \\
3.20 \\
7.23 \\
6.10 \\
5.70 \\
4.75 \\
4.70 \\
4.67 \\
4.80 \\
4.93 \\
6.60 \\
5.95 \\
5.80 \\
5.70 \\
4.65 \\
4.10 \\
4.00\end{array}$ & $\begin{array}{l}4.05 \\
4.10 \\
4.15 \\
4.20 \\
4.17 \\
4.20 \\
4.05 \\
4.10 \\
3.85 \\
3.65 \\
3.67 \\
3.63 \\
4.80 \\
4.00 \\
4.03 \\
3.80 \\
3.70 \\
3.65 \\
3.63 \\
3.60 \\
3.57 \\
3.55 \\
3.65 \\
3.70 \\
3.75 \\
3.87 \\
4.45 \\
3.85 \\
3.55 \\
3.93 \\
3.80\end{array}$ & $\begin{array}{l}3.65 \\
3.55 \\
3.50 \\
3.40 \\
3.35 \\
3.35 \\
3.27 \\
3.23 \\
3.20 \\
3.17 \\
3.15 \\
3.13 \\
3.25 \\
3.30 \\
3.17 \\
3.20 \\
3.35 \\
3.45 \\
3.40 \\
3.30 \\
3.20 \\
3.13 \\
3.15 \\
3.20 \\
3.40 \\
3.35 \\
3.25 \\
3.20 \\
3.13 \\
3.20 \\
3.30\end{array}$ & $\begin{array}{l}3.33 \\
3.20 \\
3.15 \\
3.10 \\
3.07 \\
3.10 \\
3.05 \\
3.03 \\
3.10 \\
3.05 \\
3.00 \\
2.85 \\
2.80 \\
3.40 \\
4.65 \\
5.27 \\
3.90 \\
3.80 \\
3.50 \\
3.20 \\
3.15 \\
3.13 \\
3.10 \\
3.05 \\
3.20 \\
2.70 \\
2.75 \\
2.80 \\
2.90 \\
2.90\end{array}$ & $\begin{array}{r}2.95 \\
2.93 \\
2.97 \\
.3 .10 \\
3.27 \\
3.20 \\
3.10 \\
3.10 \\
3.00 \\
2.95 \\
2.85 \\
3.00 \\
3.13 \\
3.10 \\
2.90 \\
2.80 \\
2.85 \\
2.83 \\
2.80 \\
2.75 \\
2.70 \\
3.80 \\
8.50 \\
7.45 \\
6.20 \\
4.80 \\
4.15 \\
4.00 \\
3.70 \\
3.63 \\
3.60\end{array}$ & $\begin{array}{l}3.50 \\
4.00 \\
4.13 \\
4.25 \\
4.13 \\
4.00 \\
3.85 \\
3.58 \\
3.40 \\
3.45 \\
3.47 \\
3.50 \\
3.47 \\
3.38 \\
3.35 \\
3.32 \\
3.30 \\
3.31 \\
3.35 \\
3.37 \\
3.40 \\
3.37 \\
3.33 \\
3.28 \\
4.30 \\
6.45 \\
5.27 \\
4.70 \\
4.35 \\
4.05\end{array}$ & $\begin{array}{l}3.90 \\
3.73 \\
3.64 \\
4.98 \\
4.57 \\
4.35 \\
4.07 \\
3.95 \\
3.70 \\
3.67 \\
3.55 \\
3.50 \\
3.47 \\
3.47 \\
3.49 \\
3.50 \\
3.47 \\
3.45 \\
3.44 \\
3.70 \\
5.11 \\
4.48 \\
4.40 \\
4.35 \\
4.20 \\
4.12 \\
3.85 \\
3.80 \\
3.80 \\
3.75 \\
4.45\end{array}$ \\
\hline
\end{tabular}


This is one of the temporary stations established in connection with the general hydrographic study of the southern Appalachian region. Another temporary station was established on Pigeon River, a tributary of the French Broad, and many miscellaneous measurements were made. on the French Broad and its tributaries, the results. of which are given in Paper No. 49. The Oldtown station on the French Broad was established september 4, 1900, on the highway bridge across the river at that town, which is 2 miles north of Newport, Tennessee. The bridge is a 4 -span iron structure, with wooden hand rails. The gage is securely nailed to the second span from the south end of the bridge. The 14-foot mark is the end of the rod, which is butted against the north side of the first strut from the south end of the span, on the downstream side. The outer rim of the pulley is 0.67 foot from the zero of the rod, and the distance between the end of the weight and the pointer on the wire is 25.82 feet. When the gage reads 1 foot, the water level is 20.33 feet below the top surface of the lower chord directly below the zero of the gage rod. The river is straight for a long distance above and below the bridge, and the velocity of the current is well distributed all the way across, though at the low stage at which measurement was made, some places had a velocity too small to give satisfactory results. Almost the entire distance across the bottom seems to be of fine sand. The observer is Jake Odell, Newport, Tennessee. During 1900 the following measurements were made by E. W. Myers and L. V. Branch:

September 4: Gage height, 1 foot; discharge, 867 second-feet.

November 2: Gage height, 1.26 feet; discharge, 1,653 second-feet.

December 15: Gage height, 1.30 feet; discharge, 1,976 second-teet.

December 26: Gage height, _ feet; discharge, 2,901 second-feet.

Daily gage height, in feet, of French Broad River at Oldtown, Tennessee, for 1900.

\begin{tabular}{|c|c|c|c|c|c|c|c|c|c|}
\hline Day. & Sept. & Oct. & Nov. & Dec. & Day. & Sept. & Oet. & Nov. & Dec. \\
\hline $\begin{array}{r}1 \\
1 \\
2 \\
3 \\
4\end{array}$ & $\begin{array}{r}7.00 \\
1.00 \\
.90 \\
.90 \\
.90 \\
.80 \\
.80 \\
.80 \\
.80 \\
.70 \\
1.10 \\
1.20 \\
2.90\end{array}$ & 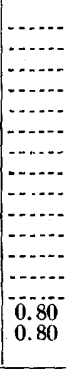 & $\begin{array}{l}1.20 \\
1.20 \\
1.50 \\
2.20 \\
1.70 \\
1.60 \\
1.40 \\
1.30 \\
1.30 \\
1.20 \\
1.20 \\
1.20 \\
1.20 \\
1.10 \\
1.10 \\
1.10\end{array}$ & $\begin{array}{l}1.60 \\
1.50 \\
1.40 \\
1.80 \\
2.80 \\
2.20 \\
1.80 \\
1.60 \\
1.70 \\
1.60 \\
1.50 \\
1.40 \\
1.40 \\
1.30 \\
1.30 \\
1.30\end{array}$ & $\begin{array}{l}17 \\
18 \\
19 \\
20 \\
21 \\
21 \\
22 \\
23 \\
24 \\
25 \\
26 \\
26 \\
28 \\
28 \\
29\end{array}$ & 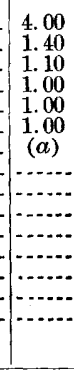 & $\begin{array}{l}.80 \\
.80 \\
.80 \\
.80 \\
.80 \\
.80 \\
2.20 \\
4.00 \\
3.80 \\
3.40 \\
1.80 \\
1.50 \\
1.40 \\
1.20 \\
1.20\end{array}$ & $\begin{array}{l}1.10 \\
1.10 \\
1.10 \\
1.10 \\
1.10 \\
1.00 \\
1.00 \\
1.10 \\
1.20 \\
4.50 \\
3.00 \\
2.20 \\
1.80 \\
1.70 \\
\cdots\end{array}$ & 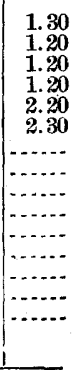 \\
\hline
\end{tabular}

$a$ No record September 23 to October 14 , inclusive. 
PIGEON RIVER AT NEWPORT, TENNESSEE.

This station was established September 4, 1900, on the wagon bridge at the upper end of the town of Newport, about 100 yards above the railroad bridge. The course of the river is straight for several hundred yards above and for about 50 yards below the bridge. The current at extreme low water is very sluggish. At even the lowest gage heights the water is very deep. The bottom is smooth, being of rock, in many places overlain with mud. The 15-foot mark of the rod, or the end, is abutted firmly against the east side of the first strut from the west end of the bridge, on the downstream side. The dis. tance between the zero of the rod and the outer rim of the pulley wheel is 0.95 foot, and from the end of the weight to the pointer on the wire the distance is 32.89 feet. When the gage reading is 1 foot, the water level is 27.42 feet below the top surface of the lower chord directly beneath the zero of the gage rod. The rod is of hard pine, well painted and divided into feet and tenths. The drainage area is 655 square miles. The observer is H. M. Boyer, proprietor of a livery stable at Newport. During 1900 the following measurements were made by E. W. Myers and L. V. Branch:

September 4: Gage height, 1.00 foot; discharge, 356 second-feet.

November 2: Gage height, - foot; discharge, 544 second-feet.

December 15: Gage beight, 1.28 feet; discharge, 691 second-feet.

December 26: Gage height, 2 feet; discharge, 935 second-feet.

Daily gage height, in feet, of Pigeon River at Newport, Tennessee, for 1900.

\begin{tabular}{|c|c|c|c|c|c|c|c|c|c|c|c|}
\hline Day. & Sept. & Nov. & Dec. & Day. & Sept. & Nov. & Dec. & Day. & Sept. & Nov. & Dec. \\
\hline $\begin{array}{r}1 \\
1 \\
3 \\
4 \\
5 \\
6 \\
7 \\
8 \\
9\end{array}$ & $\begin{array}{r}0.80 \\
.70 \\
.70 \\
.60 \\
.60 \\
.50 \\
.60\end{array}$ & 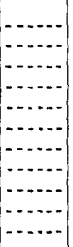 & $\begin{array}{l}1.40 \\
1.50 \\
2.60 \\
3.20 \\
2.30 \\
2.10 \\
1.90 \\
1.70 \\
1.50 \\
1.50 \\
1.40\end{array}$ & $\begin{array}{l}12 \\
13 \\
14 \\
15 \\
16 \\
17 \\
18 \\
19 \\
20 \\
21 \\
22\end{array}$ & \begin{tabular}{c}
0.60 \\
.50 \\
1.20 \\
1.60 \\
$(a)$ \\
\hdashline$\cdots$ \\
\hdashline \\
\hdashline \\
\hdashline \\
\hdashline
\end{tabular} & \begin{tabular}{|c|}
$\cdots$ \\
\hdashline$\ldots .$. \\
\hdashline 1.00 \\
\hdashline .00 \\
1.00
\end{tabular} & $\begin{array}{l}1.30 \\
1.20 \\
1.40 \\
1.30 \\
1.40 \\
1.30 \\
1.30 \\
1.40 \\
1.40 \\
2.40 \\
2.00\end{array}$ & $\begin{array}{l}23 \\
24 \\
25 \\
26 \\
27 \\
28 \\
29 \\
30 \\
31\end{array}$ & 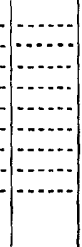 & \begin{tabular}{|}
1.10 \\
1.10 \\
1.30 \\
3.90 \\
1.90 \\
1.80 \\
1.50 \\
1.40 \\
$\cdots$
\end{tabular} & $\begin{array}{l}2.40 \\
2.60 \\
2.10 \\
2.00 \\
2.00 \\
2.00 \\
2.10 \\
2.50 \\
2.90\end{array}$ \\
\hline
\end{tabular}

$a$ No record September 16 to November 18 , inclusive.

TUCKASEGEE RIVER AT BRYSON, NORTH CAROLINA.

This station is described in Water-Supply Paper No. 36, page 167. Results of measurements during 1899 will be found in the TwentyFirst Annual Report, Part IV, page 162. During 1900 the following measurements were made by E. W. Myers and R. E. Shuford: 
Discharge measurements of Tuckasegee River at Bryson, North Carolina.

\begin{tabular}{|c|c|c|c|c|c|}
\hline Date. & $\begin{array}{c}\text { Gage } \\
\text { height. }\end{array}$ & Discharge. & - Date. & $\begin{array}{c}\text { Gage } \\
\text { height. }\end{array}$ & Discharge. \\
\hline 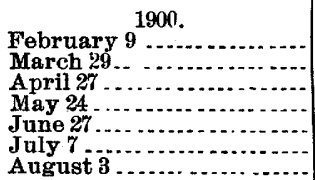 & $\begin{array}{l}\text { Feet. } \\
2.95 \\
2.50 \\
2.65 \\
1.80 \\
2.60 \\
2.00 \\
1.60\end{array}$ & \begin{tabular}{r|} 
Sec.ffet. \\
$\mathbf{3}, \mathbf{3 1 6}$ \\
$\mathbf{2}, \mathbf{3 2 1}$ \\
$\mathbf{2}, 829$ \\
$\mathbf{1}, 390$ \\
$\mathbf{2}, 673$ \\
$\mathbf{1}, \mathbf{4 7 2}$ \\
$\mathbf{9 2 0}$
\end{tabular} & $\begin{array}{l}1900 . \\
\text { September } 8 \\
\text { October } 27 \\
\text { November } 16 \\
\text { December } 12 \\
\text { Do } \\
\text { December } 26\end{array}$ & $\begin{array}{r}\text { Feet. } \\
1.20 \\
1.60 \\
1.20 \\
1.50 \\
1.50 \\
1.60\end{array}$ & $\begin{array}{r}\text { Sec.-feet. } \\
598 \\
942 \\
593 \\
998 \\
903 \\
960\end{array}$ \\
\hline
\end{tabular}

Daily gage height, in feet, of Tuckasegee River at Bryson, North Carolina, for 1900.

\begin{tabular}{|c|c|c|c|c|c|c|c|c|c|c|c|c|}
\hline Day. & Jan. & Feb. & Mar. & Apr. & May. & June. & July. & Aug. & Sept. & Oct. & Nov. & Dec. \\
\hline $\begin{array}{c}9 \\
10 \\
11\end{array}$ & $\begin{array}{l}1.50 \\
1.50 \\
1.50 \\
1.50 \\
1.50 \\
1.50 \\
1.50 \\
1.60 \\
1.60 \\
2.80 \\
3.10 \\
2.70 \\
2.90 \\
2.80 \\
2.70 \\
2.50 \\
2.50 \\
2.40 \\
2.30 \\
2.30 \\
2.30 \\
2.80 \\
2.80 \\
2.80 \\
2.60 \\
2.50 \\
2.50 \\
2.40 \\
2.40 \\
2.40 \\
2.40\end{array}$ & $\begin{array}{l}2.75 \\
2.75 \\
1.60 \\
1.60 \\
1.80 \\
1.65 \\
1.60 \\
2.00 \\
3.10 \\
2.50 \\
2.00 \\
4.00 \\
8.00 \\
4.80 \\
4.20 \\
4.15 \\
4.00 \\
3.85 \\
3.70 \\
3.50 \\
3.40 \\
3.20 \\
3.00 \\
3.00 \\
3.00 \\
2.80 \\
2.80 \\
2.80\end{array}$ & $\begin{array}{l}2.60 \\
2.55 \\
2.30 \\
2.60 \\
2.80 \\
3.30 \\
3.50 \\
3.90 \\
3.90 \\
3.85 \\
3.75 \\
3.60 \\
3.50 \\
2.40 \\
2.40 \\
2.35 \\
3.00 \\
3.50 \\
2.65 \\
.60 \\
2.85 \\
2.60 \\
6.45 \\
2.50 \\
3.00 \\
2.60 \\
2.55 \\
2.40 \\
2.35 \\
2.35 \\
2.20\end{array}$ & $\begin{array}{l}2.15 \\
2.15 \\
2.40 \\
2.30 \\
2.25 \\
2.25 \\
2.20 \\
2.15 \\
2.15 \\
2.20 \\
2.40 \\
2.40 \\
2.70 \\
2.30 \\
2.10 \\
2.20 \\
2.20 \\
3.50 \\
3.00 \\
2.80 \\
3.90 \\
2.80 \\
3.30 \\
2.50 \\
2.60 \\
2.70 \\
2.60 \\
2.50 \\
2.30 \\
2.50\end{array}$ & $\begin{array}{l}2.30 \\
2.20 \\
2.30 \\
2.10 \\
2.10 \\
2.10 \\
2.00 \\
.00 \\
2.00 \\
2.00 \\
1.90 \\
1.80 \\
1.80 \\
1.80 \\
1.70 \\
1.70 \\
1.70 \\
1.70 \\
1.70 \\
1.70 \\
1.60 \\
1.60 \\
1.60 \\
1.85 \\
1.90 \\
1.80 \\
1.60 \\
1.60 \\
1.60 \\
1.50 \\
1.40\end{array}$ & $\begin{array}{l}1.50 \\
1.60 \\
1.60 \\
1.70 \\
2.10 \\
2.00 \\
1.90 \\
1.90 \\
2.10 \\
2.00 \\
1.90 \\
1.90 \\
1.90 \\
1.90 \\
1.80 \\
3.00 \\
3.60 \\
3.40 \\
3.00 \\
2.40 \\
2.20 \\
3.40 \\
3.50 \\
4.30 \\
3.00 \\
2.90 \\
2.70 \\
2.50 \\
3.50 \\
3.00\end{array}$ & $\begin{array}{l}2.50 \\
. .40 \\
2.40 \\
2.20 \\
2.20 \\
2.10 \\
2.00 \\
2.00 \\
2.10 \\
1.80 \\
2.00 \\
1.90 \\
2.00 \\
2.00 \\
2.00 \\
1.90 \\
1.90 \\
1.90 \\
1.80 \\
1.80 \\
2.00 \\
2.10 \\
2.00 \\
1.80 \\
1.60 \\
1.60 \\
2.50 \\
2.40 \\
2.20 \\
2.00 \\
1.60\end{array}$ & $\begin{array}{l}1.60 \\
1.60 \\
1.50 \\
1.50 \\
1.50 \\
1.50 \\
1.40 \\
1.40 \\
1.40 \\
1.40 \\
1.40 \\
1.40 \\
1.50 \\
1.50 \\
1.40 \\
1.40 \\
1.40 \\
1.25 \\
1.30 \\
1.30 \\
1.30 \\
1.90 \\
1.50 \\
1.50 \\
1.30 \\
1.50 \\
1.50 \\
1.40 \\
1.40 \\
1.40 \\
1.50\end{array}$ & $\begin{array}{l}1.40 \\
1.50 \\
1.40 \\
1.30 \\
1.30 \\
1.30 \\
1.20 \\
1.20 \\
1.20 \\
1.20 \\
1.20 \\
1.15 \\
1.15 \\
1.80 \\
2.90 \\
2.10 \\
1.70 \\
1.50 \\
1.40 \\
1.40 \\
1.40 \\
1.50 \\
1.35 \\
1.30 \\
1.30 \\
1.25 \\
1.25 \\
1.20 \\
1.20\end{array}$ & $\begin{array}{l}1.20 \\
1.20 \\
1.20 \\
1.25 \\
1.25 \\
1.20 \\
1.20 \\
1.20 \\
1.20 \\
1.15 \\
1.15 \\
1.20 \\
1.35 \\
1.20 \\
1.20 \\
1.15 \\
1.10 \\
1.10 \\
1.10 \\
1.20 \\
5.20 \\
2.20 \\
1.80 \\
1.60 \\
1.40 \\
1.40 \\
1.40 \\
1.35\end{array}$ & $\begin{array}{l}1.35 \\
1.35 \\
2.10 \\
1.70 \\
1.50 \\
1.50 \\
1.40 \\
1.40 \\
1.30 \\
1.30 \\
1.30 \\
1.30 \\
1.30 \\
1.30 \\
1.30 \\
1.25 \\
1.20 \\
1.15 \\
1.35 \\
1.30 \\
1.25 \\
3.10 \\
4.80 \\
2.10 \\
1.80 \\
1.70 \\
1.60\end{array}$ & $\begin{array}{l}1.50 \\
1.40 \\
3.30 \\
2.50 \\
2.20 \\
2.00 \\
1.80 \\
1.70 \\
1.60 \\
1.60 \\
1.60 \\
1.55 \\
1.50 \\
1.50 \\
1.45 \\
.40 \\
1.40 \\
1.40 \\
1.40 \\
1.80 \\
1.30 \\
1.70 \\
2.00 \\
1.80 \\
1.70 \\
1.60 \\
1.70 \\
1.60 \\
1.80 \\
2.50\end{array}$ \\
\hline
\end{tabular}

\section{LITTLE TENNESSEE RIVER AT JUDSON, NORTH CAROLINA.}

This station is described in Water-Supply Paper No. 36, page 168. Records of measurements for 1899 will be found in the Twenty-first Annual Report, Part IV, page 163. During 1900 the following measurements were made by E. W. Myers and R. A. Shuford:

February 10: Gage height, 4.55 feet; discharge, 3,726 second-feet. March 30: Gage height, 4.40 feet; discharge, 3,179 second-feet.

April 28: Gage height, 4.55 feet; discharge, 3,785 second-feet.

May 25: Gage height, 3.50 feet; discharge, 1,744 second-feet.

June 28: Gage height, 5 feet; discharge, 4,644 second-feet.

August 4: Gage height, 3.45 feet; discharge, 1,668 second-feet.

November 17: Gage height, 2.88 feet; discharge, 1,008 second-feet.

December 27: Gage height, 3.40 feet; discharge, 1,414 second-feet. 
Daily gage height, in feet, of Little Tennessee River at Judson, North Carolina, for 1900.

\begin{tabular}{|c|c|c|c|c|c|c|c|c|c|c|c|c|}
\hline Day. & Jan. & Feb. & Mar. & Apt. & May. & June. & July. & Aug. & Sept. & Oct. & Nov. & Dec. \\
\hline $\begin{array}{l}10 \\
11 \\
12 \\
13 \\
14\end{array}$ & \begin{tabular}{|l}
2.36 \\
2.36 \\
2.38 \\
2.32 \\
2.32 \\
2.30 \\
2.31 \\
2.31 \\
2.33 \\
2.34 \\
2.34 \\
2.42 \\
4.38 \\
3.72 \\
2.91 \\
2.90 \\
2.90 \\
2.83 \\
2.82 \\
2.81 \\
2.82 \\
2.85 \\
2.87 \\
2.72 \\
2.75 \\
2.78 \\
2.78 \\
2.73 \\
2.72 \\
2.69 \\
2.69
\end{tabular} & \begin{tabular}{|r}
2.65 \\
2.70 \\
2.68 \\
2.67 \\
2.67 \\
2.67 \\
2.69 \\
3.72 \\
3.40 \\
3.78 \\
4.37 \\
3.39 \\
3.33 \\
1.35 \\
5.68 \\
4.58 \\
3.33 \\
3.41 \\
3.48 \\
3.48 \\
3.52 \\
3.58 \\
3.58 \\
3.62 \\
3.69 \\
3.63 \\
3.60 \\
3.90 \\
3.80 \\
\end{tabular} & \begin{tabular}{|l|}
6.33 \\
4.42 \\
3.78 \\
3.70 \\
3.70 \\
3.84 \\
3.84 \\
3.93 \\
6.40 \\
4.30 \\
4.40 \\
4.58 \\
4.58 \\
3.98 \\
3.93 \\
4.38 \\
4.40 \\
3.99 \\
3.98 \\
3.98 \\
3.90 \\
3.90 \\
3.94 \\
3.93 \\
3.90 \\
3.90 \\
3.82 \\
3.80 \\
3.84 \\
3.84 \\
3.71
\end{tabular} & $\begin{array}{l}3.68 \\
3.67 \\
3.67 \\
3.41 \\
3.33 \\
3.30 \\
2.91 \\
2.88 \\
2.80 \\
2.74 \\
2.79 \\
5.45 \\
5.92 \\
4.39 \\
3.58 \\
3.92 \\
3.00 \\
3.54 \\
3.50 \\
4.38 \\
3.49 \\
3.48 \\
3.48 \\
3.40 \\
3.40 \\
3.32 \\
3.33 \\
3.29 \\
3.28 \\
3.28\end{array}$ & 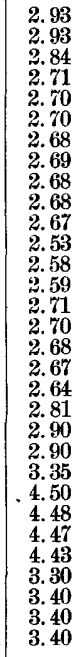 & $\begin{array}{l}3.40 \\
4.00 \\
3.52 \\
3.76 \\
3.52 \\
3.62 \\
3.72 \\
4.00 \\
3.82 \\
3.62 \\
3.52 \\
3.62 \\
4.62 \\
4.00 \\
3.82 \\
3.92 \\
3.88 \\
3.89 \\
3.84 \\
4.48 \\
4.67 \\
4.93 \\
5.41 \\
5.40 \\
5.40 \\
5.91 \\
5.90 \\
5.88 \\
5.83 \\
5.71\end{array}$ & $\begin{array}{l}5.68 \\
5.69 \\
5.69 \\
5.66 \\
4.38 \\
4.32 \\
4.32 \\
4.61 \\
4.60 \\
4.74 \\
3.61 \\
3.71 \\
3.71 \\
3.91 \\
4.38 \\
4.32 \\
3.81 \\
3.71 \\
3.51 \\
3.51 \\
3.41 \\
3.51 \\
3.71 \\
3.71 \\
3.41 \\
3.71 \\
3.61 \\
4.31 \\
4.00 \\
3.91 \\
3.71\end{array}$ & $\begin{array}{l}3.71 \\
3.61 \\
3.51 \\
3.41 \\
3.41 \\
3.41 \\
3.31 \\
3.31 \\
3.21 \\
3.21 \\
3.21 \\
3.21 \\
3.21 \\
3.11 \\
3.21 \\
3.11 \\
3.11 \\
3.21 \\
3.22 \\
3.28 \\
3.28 \\
3.29 \\
3.28 \\
3.27 \\
3.27 \\
3.22 \\
3.20 \\
3.21 \\
3.21 \\
3.23 \\
3.23\end{array}$ & $\begin{array}{l}3.19 \\
3.18 \\
3.10 \\
3.10 \\
3.11 \\
3.13 \\
3.12 \\
3.13 \\
3.11 \\
3.11 \\
3.14 \\
3.13 \\
3.14 \\
3.15 \\
3.16 \\
3.16 \\
3.19 \\
3.20 \\
3.20 \\
3.21 \\
3.22 \\
3.21 \\
3.20 \\
3.22 \\
3.22 \\
3.21 \\
3.23 \\
3.20 \\
3.21 \\
3.22\end{array}$ & $\begin{array}{l}3.21 \\
3.22 \\
3.22 \\
3.22 \\
3.22 \\
3.21 \\
3.20 \\
3.21 \\
3.22 \\
3.22 \\
3.23 \\
2.51 \\
2.61 \\
2.81 \\
2.71 \\
2.61 \\
2.61 \\
2.61 \\
2.61 \\
2.51 \\
2.51 \\
2.59 \\
2.61 \\
3.61 \\
6.71 \\
5.21 \\
3.71 \\
3.51 \\
2.51 \\
3.31 \\
3.30 \\
3.30\end{array}$ & $\begin{array}{l}3.00 \\
3.00 \\
3.50 \\
3.41 \\
3.10 \\
3.00 \\
3.00 \\
2.91 \\
2.91 \\
2.91 \\
2.91 \\
2.91 \\
2.81 \\
2.81 \\
2.81 \\
2.81 \\
2.81 \\
2.81 \\
2.81 \\
2.81 \\
3.00 \\
3.00 \\
2.81 \\
2.81 \\
3.61 \\
4.81 \\
4.00 \\
3.01 \\
3.51 \\
3.51\end{array}$ & $\begin{array}{l}3.31 \\
3.29 \\
3.28 \\
6.07 \\
5.63 \\
4.28 \\
4.22 \\
3.10 \\
3.14 \\
3.14 \\
3.14 \\
3.15 \\
3.25 \\
3.25 \\
3.19 \\
3.23 \\
3.24 \\
3.21 \\
3.21 \\
3.92 \\
5.68 \\
4.91 \\
3.72 \\
3.69 \\
3.68 \\
3.65 \\
3.65 \\
3.65 \\
3.92 \\
3.48 \\
3.43\end{array}$ \\
\hline
\end{tabular}

HIWASSEE RIVER AT MURPHY, NORTH CAROLINA.

This station is described in Water-Supply Paper No. 36, page 169. The observer is William Mingus, of Murphy. Records of measurements during 1899 will be found in the Twenty-first Annual Report, Part IV, page 165. During 1900 the following measurements were made by E. W. Myers and R. E. Shuford:

Discharge measurements of Hiwassee River at Murphy, North Carolina.

\begin{tabular}{|c|c|c|c|c|c|}
\hline Date. & $\begin{array}{c}\text { Gage } \\
\text { height. }\end{array}$ & Discharge. & Date. & $\begin{array}{c}\text { Gage } \\
\text { height. }\end{array}$ & Discharge. \\
\hline $\begin{array}{l}\text { February } 11900 . \\
\text { February } 14 \ldots \\
\text { April } 29 \\
\text { May } 26 \\
\text { June } 29 \\
\text { July } 8\end{array}$ & $\begin{array}{l}\text { Feet. } \\
6.10 \\
7.95 \\
6.10 \\
5.52 \\
7.10 \\
5.90\end{array}$ & $\begin{array}{r}\text { Sec.-ft. } \\
1,534 \\
4,567 \\
1,466 \\
755 \\
3,405 \\
1,155\end{array}$ & $\begin{array}{l}1900 . \\
\text { September } 9 \\
\text { November } 18 \\
\text { December } 13 \\
\text { December } 13 \\
\text { December } 28\end{array}$ & $\begin{array}{l}\text { Feet. } \\
\mathbf{5 . 0 5} \\
\mathbf{5 . 2 0} \\
\mathbf{5 . 5 3} \\
\mathbf{5 . 4 5} \\
\mathbf{5 . 7 0}\end{array}$ & $\begin{array}{r}\text { Sec.-ft. } \\
345 \\
443 \\
762 \\
698 \\
865\end{array}$ \\
\hline
\end{tabular}


Daily gage height, in feet, of Hiwassee River at Murphy, North Carolina, for 1900.

\begin{tabular}{|c|c|c|c|c|c|c|c|c|c|c|c|c|}
\hline Day. & Jan. & Feb. & Mar. & Apr. & May. & June. & July. & Aug. & Sept. & Oct. & Nov. & Dec. \\
\hline 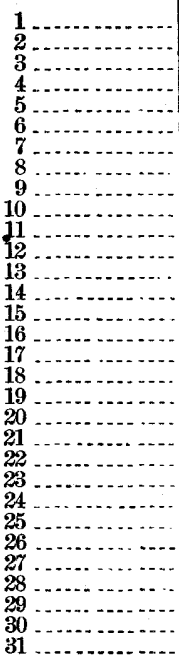 & \begin{tabular}{|c}
5.50 \\
5.20 \\
5.51 \\
5.30 \\
5.30 \\
5.20 \\
5.20 \\
5.20 \\
5.20 \\
5.20 \\
5.30 \\
6.30 \\
5.80 \\
5.60 \\
5.60 \\
5.50 \\
5.40 \\
5.45 \\
5.90 \\
6.60 \\
6.20 \\
5.90 \\
5.80 \\
5.65 \\
5.60 \\
5.60 \\
5.50 \\
5.40 \\
5.40 \\
5.40 \\
5.50
\end{tabular} & $\begin{array}{c}5.12 \\
5.30 \\
5.35 \\
5.40 \\
5.60 \\
5.40 \\
5.40 \\
5.40 \\
6.72 \\
6.02 \\
6.10 \\
6.10 \\
1.60 \\
7.70 \\
7.15 \\
6.50 \\
6.20 \\
5.90 \\
5.90 \\
5.80 \\
6.00 \\
6.40 \\
6.15 \\
6.00 \\
6.00 \\
5.00 \\
5.85\end{array}$ & $\begin{array}{l}7.00 \\
6.50 \\
6.25 \\
6.10 \\
6.00 \\
6.00 \\
7.00 \\
7.50 \\
7.40 \\
6.90 \\
6.60 \\
6.40 \\
6.30 \\
6.12 \\
6.05 \\
6.30 \\
6.00 \\
6.00 \\
7.40 \\
6.90 \\
6.60 \\
6.40 \\
6.35 \\
6.40 \\
6.40 \\
6.30 \\
6.30 \\
6.10 \\
6.00\end{array}$ & $\begin{array}{l}5.90 \\
5.90 \\
5.90 \\
6.70 \\
6.10 \\
6.05 \\
6.00 \\
5.90 \\
5.85 \\
5.80 \\
6.10 \\
6.30 \\
6.10 \\
6.00 \\
5.00 \\
5.90 \\
6.80 \\
6.70 \\
6.40 \\
7.10 \\
6.80 \\
6.70 \\
6.55 \\
6.55 \\
6.30 \\
6.20 \\
6.20 \\
6.10\end{array}$ & $\begin{array}{l}6.10 \\
6.00 \\
6.00 \\
5.90 \\
5.90 \\
5.80 \\
5.70 \\
5.70 \\
5.70 \\
5.70 \\
5.70 \\
5.65 \\
5.60 \\
5.60 \\
5.60 \\
5.50 \\
5.40 \\
5.50 \\
5.70 \\
5.50 \\
5.40 \\
5.40 \\
5.40 \\
5.60 \\
5.50 \\
5.60 \\
5.50 \\
5.50 \\
5.40 \\
5.40 \\
5.40\end{array}$ & $\begin{array}{l}5.40 \\
5.40 \\
5.60 \\
5.80 \\
5.50 \\
6.10 \\
6.00 \\
6.10 \\
6.10 \\
6.30 \\
6.10 \\
6.10 \\
6.60 \\
6.10 \\
5.80 \\
5.80 \\
6.20 \\
6.00 \\
6.30 \\
6.10 \\
5.90 \\
5.80 \\
6.30 \\
6.60 \\
6.50 \\
7.00 \\
7.20 \\
7.10 \\
7.00 \\
6.80\end{array}$ & $\begin{array}{l}6.80 \\
6.60 \\
7.00 \\
6.40 \\
6.20 \\
6.00 \\
5.90 \\
5.80 \\
6.20 \\
5.70 \\
5.70 \\
5.80 \\
5.80 \\
5.70 \\
5.60 \\
5.60 \\
5.60 \\
5.60 \\
5.50 \\
5.50 \\
5.50 \\
5.60 \\
5.70 \\
5.60 \\
5.40 \\
5.50 \\
5.70 \\
5.90 \\
5.70 \\
5.80 \\
5.60\end{array}$ & $\begin{array}{l}5.80 \\
5.40 \\
5.40 \\
5.40 \\
5.30 \\
5.30 \\
5.30 \\
5.20 \\
5.20 \\
5.20 \\
5.20 \\
5.20 \\
5.20 \\
5.20 \\
55.20 \\
5.10 \\
55.30 \\
5.20 \\
5.10 \\
5.10 \\
5.10 \\
5.10 \\
5.30 \\
5.90 \\
5.30 \\
5.40 \\
5.20 \\
5.15 \\
5.15 \\
5.15 \\
5.15\end{array}$ & $\begin{array}{l}5.35 \\
5.20 \\
5.15 \\
5.10 \\
5.20 \\
5.15 \\
5.10 \\
5.05 \\
5.05 \\
5.00 \\
5.00 \\
5.00 \\
5.00 \\
5.05 \\
7.00 \\
6.45 \\
5.70 \\
5.45 \\
5.35 \\
5.35 \\
5.25 \\
5.00 \\
5.40 \\
5.20 \\
5.20 \\
5.20 \\
5.15 \\
5.15 \\
5.10 \\
5.05\end{array}$ & $\begin{array}{l}5.00 \\
4.90 \\
5.00 \\
5.10 \\
5.10 \\
5.05 \\
5.00 \\
5.30 \\
5.10 \\
5.05 \\
5.00 \\
4.90 \\
5.30 \\
5.10 \\
5.00 \\
4.90 \\
4.80 \\
4.00 \\
4.90 \\
5.00 \\
4.90 \\
7.10 \\
6.00 \\
5.70 \\
5.60 \\
5.40 \\
5.30 \\
5.20 \\
5.25\end{array}$ & $\begin{array}{l}5.20 \\
5.25 \\
6.20 \\
5.60 \\
5.40 \\
5.35 \\
5.35 \\
5.30 \\
5.25 \\
5.25 \\
5.20 \\
5.25 \\
5.20 \\
5.25 \\
5.20 \\
5.15 \\
5.20 \\
5.15 \\
5.20 \\
5.15 \\
5.20 \\
5.30 \\
5.20 \\
5.15 \\
5.30 \\
6.70 \\
6.00 \\
5.70 \\
5.60 \\
5.50\end{array}$ & $\begin{array}{l}5.40 \\
5.45 \\
5.40 \\
7.20 \\
6.40 \\
6.00 \\
5.80 \\
5.75 \\
5.60 \\
5.60 \\
5.50 \\
5.50 \\
5.45 \\
5.45 \\
5.40 \\
5.40 \\
5.40 \\
5.30 \\
5.30 \\
5.80 \\
6.70 \\
5.90 \\
5.80 \\
6.00 \\
5.80 \\
5.70 \\
5.65 \\
5.60 \\
5.70\end{array}$ \\
\hline
\end{tabular}

\section{HIWASSEE RIVER AT RELIANCE, TENNESSEE.}

This station was established by O. P. Hall on August 17, 1900. The gage is a vertical timber, graduated to feet and tenths, spiked to a tree on the right bank of the river abont 200 feet above the Atlanta, Knoxville and Northern Railroad bridge, and very near the ferry landing. Measurements are made from the railroad bridge, a new steel structure of three spans of 140 feet each, which has recently been substituted for the old wooden bridge. Bench mark No. 1 is a nail in a hickory tree on the right bank of the river, about 100 feet above the end of the bridge and 8.56 feet above the zero of the gage. Bench mark No. 2 is the base of rail 40 feet from the right-bank end of bridge, and is 24.70 feet above the zero of the gage. At ordinary stages the river is about 350 feet wide at this point, and the section is a fairly good one, but at low stages the current becomes very sluggish. The observer is C. V. Higdon, a ferryman who lives near the gage. During 1900 the following measurements were made by O. P. Hall:

August 17: Gage height, 1.12 feet; discharge, 1,123 second-feet.

September 3: Gage height, 1.16 feet; discharge, 1,159 second-feet.

November 30: Gage height, 1.72 feet; discharge, 1,985 second-feet.

December 19: Gage height, 1.42 feet; discharge, 1,442 second-feet. 
Daily gage height, in feet, of Hiwassee River at Reliance, Tennessee, for 1900.

\begin{tabular}{|c|c|c|c|c|c|c|c|c|c|c|c|}
\hline Day. & Aug. & Sept. & Oct. & Nor. & Dec. & Day. & Ang. & Sept. & Oct. & Nov. & Dec. \\
\hline 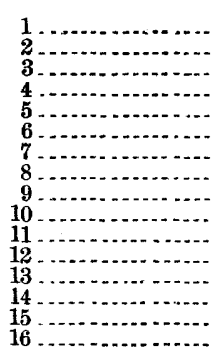 & 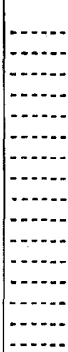 & \begin{tabular}{|r|}
1.40 \\
1.30 \\
1.20 \\
1.05 \\
1.00 \\
1.10 \\
1.05 \\
1.00 \\
1.00 \\
.90 \\
.90 \\
.90 \\
.90 \\
1.00 \\
3.60 \\
3.50
\end{tabular} & $\begin{array}{l}1.05 \\
1.00 \\
1.00 \\
1.00 \\
1.00 \\
1.00 \\
1.00 \\
1.30 \\
1.50 \\
1.20 \\
1.10 \\
1.10 \\
1.20 \\
1.40 \\
1.10 \\
1.00\end{array}$ & $\begin{array}{l}1.30 \\
1.20 \\
1.80 \\
1.30 \\
1.40 \\
1.50 \\
1.40 \\
1.40 \\
1.30 \\
1.30 \\
1.40 \\
1.30 \\
1.30 \\
1.30 \\
1.20 \\
1.20\end{array}$ & $\begin{array}{l}1.60 \\
1.50 \\
1.50 \\
2.80 \\
3.00 \\
2.40 \\
2.00 \\
2.00 \\
1.90 \\
1.80 \\
1.70 \\
1.60 \\
1.60 \\
1.60 \\
1.50 \\
1.50\end{array}$ & \begin{tabular}{|l}
17 \\
18 \\
18
\end{tabular} & $\begin{array}{l}1.10 \\
1.05 \\
1.05 \\
1.05 \\
1.10 \\
1.50 \\
1.40 \\
1.30 \\
1.15 \\
1.10 \\
1.10 \\
1.10\end{array}$ & $\begin{array}{l}2.00 \\
1.60 \\
1.40 \\
1.30 \\
1.20 \\
1.20 \\
1.30 \\
1.20 \\
1.10 \\
1.10 \\
1.05 \\
1.05 \\
1.05\end{array}$ & $\begin{array}{r}1.00 \\
1.00 \\
.90 \\
1.90 \\
1.00 \\
1.30 \\
4.00 \\
2.00 \\
1.50 \\
1.60 \\
1.50 \\
1.50 \\
1.40 \\
1.30\end{array}$ & $\begin{array}{l}1.20 \\
1.10 \\
1.10 \\
1.20 \\
1.30 \\
1.40 \\
1.30 \\
1.50 \\
1.50 \\
3.60 \\
2.00 \\
1.80 \\
1.70\end{array}$ & $\begin{array}{l}1.50 \\
1.50 \\
1.40 \\
1.50 \\
2.80 \\
2.80 \\
2.10 \\
2.40 \\
2.30 \\
2.00 \\
1.90 \\
1.90 \\
2.00 \\
1.90 \\
2.40\end{array}$ \\
\hline
\end{tabular}

AIWASSEE RIVER AT CHARLESTON, TENNESSEE.

This station was originally established by the United States Engineer Corps, but is now maintained as a half-year station by the United States Weather Bureau. It is described in Water-Supply Paper No. 36, pages 170 and 171, where will also be found the records of measurements made during 1899. During 1900 the following measurements were made by Max Hall:

March 14: Gage height, 3.50 feet; discharge, 6,044 second-feet.

April 25: Gage height, 4 feet; discharge, 7,078 second-feet.

December 8: Gage height, 2.65 feet; discharge, 4,729 second-feet.

Daily gage height, in feet, of Hiwassee River at Charleston, Tennessee, for 1900.

\begin{tabular}{|c|c|c|c|c|c|c|c|c|c|c|c|c|}
\hline Day. & Jan. & Feb. & Mar. & Apr. & May. & June. & July. & Aug. & Sept. & Oct. & Nov. & Dec. \\
\hline $\begin{array}{l}22 \\
23 \\
24\end{array}$ & $\begin{array}{r}1.0 \\
1.0 \\
.9 \\
.0 \\
1.9 \\
1.2 \\
1.1 \\
1.1 \\
1.1 \\
1.4 \\
4.6 \\
5.0 \\
3.0 \\
2.4 \\
2.0 \\
1.8 \\
1.7 \\
2.4 \\
6.4 \\
5.4 \\
3.7 \\
2.9 \\
2.5 \\
2.3 \\
2.1 \\
1.9 \\
1.8 \\
1.7 \\
1.5 \\
1.4\end{array}$ & $\begin{array}{r}1.2 \\
1.0 \\
1.2 \\
1.6 \\
1.8 \\
2.3 \\
1.7 \\
1.6 \\
2.9 \\
4.9 \\
3.2 \\
3.1 \\
14.2 \\
18.6 \\
9.2 \\
6.2 \\
4.7 \\
3.6 \\
3.0 \\
2.8 \\
2.7 \\
5.1 \\
5.0 \\
3.7 \\
4.2 \\
3.8 \\
3.3 \\
12.9 \\
\hdashline \cdots . . . \\
0 . . . \\
\hdashline \cdots . .\end{array}$ & $\begin{array}{r}3.7 \\
5.8 \\
4.5 \\
3.7 \\
3.2 \\
2.9 \\
4.5 \\
9.0 \\
11.5 \\
8.0 \\
6.0 \\
4.8 \\
4.0 \\
3.7 \\
3.4 \\
3.9 \\
4.1 \\
3.4 \\
3.3 \\
7.5 \\
9.0 \\
6.0 \\
5.0 \\
4.5 \\
4.0 \\
6.0 \\
5.2 \\
4.4 \\
3.9 \\
3.6 \\
3.3\end{array}$ & $\begin{array}{r}3.1 \\
2.9 \\
2.9 \\
4.6 \\
6.0 \\
4.0 \\
3.4 \\
3.2 \\
3.0 \\
2.9 \\
3.0 \\
4.9 \\
4.6 \\
3.7 \\
3.3 \\
3.0 \\
3.7 \\
5.1 \\
5.2 \\
5.0 \\
5.4 \\
6.4 \\
5.3 \\
4.6 \\
4.3 \\
4.0 \\
3.9 \\
3.7 \\
3.5 \\
3.3 \\
-. . .\end{array}$ & $\begin{array}{l}3.1 \\
2.9 \\
3.0 \\
2.9 \\
2.6 \\
2.5 \\
2.4 \\
2.3 \\
2.3 \\
2.5 \\
2.3 \\
2.1 \\
2.0 \\
2.0 \\
1.9 \\
1.9 \\
1.8 \\
1.7 \\
1.9 \\
2.1 \\
1.8 \\
1.7 \\
1.6 \\
1.7 \\
2.0 \\
2.0 \\
2.1 \\
1.7 \\
1.6 \\
1.5 \\
1.5\end{array}$ & $\begin{array}{l}1.5 \\
1.6 \\
2.0 \\
2.2 \\
2.2 \\
2.1 \\
3.3 \\
4.4 \\
3.5 \\
3.0 \\
3.1 \\
3.4 \\
3.7 \\
4.7 \\
3.2 \\
2.8 \\
4.0 \\
4.6 \\
3.6 \\
3.6 \\
2.7 \\
2.3 \\
2.6 \\
4.2 \\
4.8 \\
5.0 \\
5.3 \\
5.9 \\
5.7 \\
8.0 \\
\cdots . . .\end{array}$ & $\begin{array}{l}5.8 \\
4.7 \\
5.0 \\
4.9 \\
3.5 \\
3.0 \\
2.7 \\
2.5 \\
2.5 \\
2.3 \\
2.2 \\
2.0 \\
2.2 \\
2.2 \\
2.1 \\
1.9 \\
1.8 \\
1.7 \\
1.7 \\
1.6 \\
1.6 \\
1.8 \\
1.8 \\
1.8 \\
1.6 \\
2.7 \\
3.8 \\
3.7 \\
2.7 \\
2.4\end{array}$ & $\begin{array}{r}2.0 \\
1.8 \\
1.6 \\
1.5 \\
1.4 \\
1.4 \\
1.3 \\
1.3 \\
1.2 \\
1.2 \\
1.1 \\
1.1 \\
1.1 \\
1.2 \\
1.2 \\
1.1 \\
1.0 \\
1.0 \\
1.1 \\
1.0 \\
.9 \\
1.0 \\
1.2 \\
2.4 \\
1.5 \\
1.4 \\
1.5 \\
1.2 \\
1.2 \\
1.0\end{array}$ & $\begin{array}{r}1.2 \\
1.6 \\
1.2 \\
1.0 \\
.9 \\
.9 \\
.9 \\
.8 \\
.7 \\
.7 \\
.7 \\
.6 \\
.6 \\
.6 \\
3.0 \\
6.6 \\
3.3 \\
2.0 \\
1.5 \\
1.3 \\
1.2 \\
1.1 \\
1.2 \\
1.3 \\
1.1 \\
1.0 \\
.9 \\
.9 \\
.9 \\
.8\end{array}$ & $\begin{array}{r}0.7 \\
.7 \\
.7 \\
.7 \\
.7 \\
.7 \\
1.8 \\
2.0 \\
1.3 \\
1.0 \\
1.1 \\
1.7 \\
1.4 \\
1.2 \\
1.0 \\
.9 \\
.7 \\
.7 \\
.7 \\
.7 \\
1.3 \\
9.0 \\
3.8 \\
2.3 \\
1.8 \\
1.7 \\
1.5 \\
1.4 \\
1.3\end{array}$ & $\begin{array}{r}1.2 \\
1.2 \\
1.7 \\
3.9 \\
2.4 \\
1.8 \\
1.6 \\
1.4 \\
1.4 \\
1.3 \\
1.2 \\
1.2 \\
1.1 \\
1.1 \\
1.1 \\
1.0 \\
1.0 \\
1.0 \\
1.2 \\
1.3 \\
1.4 \\
1.2 \\
1.3 \\
10.0 \\
7.0 \\
4.0 \\
2.9 \\
2.3\end{array}$ & $\begin{array}{l}2.1 \\
1.9 \\
1.8 \\
2.5 \\
6.7 \\
4.3 \\
3.1 \\
.2 .8 \\
2.6 \\
2.3 \\
2.1 \\
2.0 \\
1.9 \\
1.8 \\
1.8 \\
1.7 \\
1.6 \\
1.6 \\
1.5 \\
1.5 \\
3.1 \\
3.8 \\
2.8 \\
4.1 \\
3.6 \\
2.9 \\
2.6 \\
2.4 \\
2.6 \\
2.6 \\
3.9\end{array}$ \\
\hline
\end{tabular}




\section{TOCCOA RIVER NEAR BLUERIDGE, GEORGIA.}

This station, which was established by B. M. Hall November 25, 1898 , is at the Morganton bridge, about 4 miles east of the town of Blueridge. It is deseribed in Water-Supply Paper No. 36, page 171. Records of measurements for 1899 will be found in the Twenty-first Annual Report, Part IV, page 166. During 1900 the following measurements were made by B. M. Hall and his assistants.

March 23: Gage height, 3.36 feet; discharge, 967 second-feet.

Nay 18: Gage height, 2.90 feet; discharge, 679 second-feet.

November 28: Gage height, 2.95 feet; discharge, 626 second-feet.

July 19: Gage height, 2.90 feet; discharge, 680 second-feet.

December 17: Gage height, 2.65 feet; discharge, 419 second-feet.

Daily gage height, in feet, of Toccoa River near Blueridge, Georgia, for 1900.

\begin{tabular}{|c|c|c|c|c|c|c|c|c|c|c|}
\hline Day. & Mar. & Apr. & May. & June. & July. & Aug. & Sept. & Oct. & Nov. & Dec. \\
\hline $\begin{array}{r}2 \\
3 \\
3 \\
4\end{array} 5$ & $\begin{array}{r}3.4 \\
3.5 \\
3.6 \\
3.5 \\
3.5 \\
3.4 \\
3.3 \\
3.2 \\
3.2\end{array}$ & $\begin{array}{l}3.1 \\
3.1 \\
3.1 \\
3.0 \\
3.0 \\
3.0 \\
3.0 \\
3.0 \\
3.0 \\
3.0 \\
3.4 \\
3.2 \\
3.0 \\
3.0 \\
3.0 \\
3.0 \\
3.3 \\
3.5 \\
3.5 \\
3.4 \\
3.3 \\
3.3 \\
3.3 \\
3.2 \\
3.5 \\
3.5 \\
3.6 \\
3.5 \\
3.4 \\
3.6\end{array}$ & 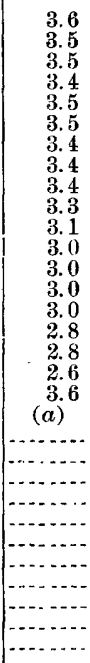 & $\begin{array}{r} \\
\\
\\
\end{array}$ & $\begin{array}{l}4.3 \\
4.3 \\
4.2 \\
4.2 \\
4.1 \\
3.6 \\
3.6 \\
3.5 \\
3.5 \\
3.5 \\
3.4 \\
3.4 \\
3.4 \\
3.3 \\
3.3 \\
3.3 \\
3.3 \\
3.2 \\
3.2 \\
3.2 \\
3.1 \\
3.1 \\
3.6 \\
3.5 \\
3.5 \\
3.5 \\
4.0 \\
4.0 \\
3.8 \\
3.8 \\
3.6\end{array}$ & $\begin{array}{l}3.6 \\
3.5 \\
3.4 \\
3.4 \\
3.4 \\
3.4 \\
3.4 \\
3.4 \\
3.3 \\
3.3 \\
3.3 \\
3.2 \\
3.2 \\
3.2 \\
3.1 \\
2.8 \\
2.8 \\
2.8 \\
2.8 \\
2.8 \\
2.8 \\
3.0 \\
3.0 \\
3.0 \\
2.8 \\
2.8 \\
2.8 \\
2.7 \\
2.7 \\
2.7 \\
2.6\end{array}$ & $\begin{array}{l}2.6 \\
2.6 \\
2.6 \\
2.6 \\
2.6 \\
2.6 \\
2.6 \\
2.6 \\
2.6 \\
2.6 \\
2.6 \\
2.6 \\
3.0 \\
3.4 \\
4.0 \\
3.6 \\
3.4 \\
3.4 \\
3.2 \\
3.2 \\
3.0 \\
3.0 \\
2.8 \\
2.8 \\
2.6 \\
2.5 \\
2.5 \\
2.5 \\
2.5 \\
2.5\end{array}$ & $\begin{array}{l}2.5 \\
2.5 \\
2.5 \\
2.6 \\
2.6 \\
2.6 \\
2.6 \\
2.6 \\
2.6 \\
2.8 \\
2.8 \\
2.9 \\
2.9 \\
2.8 \\
2.8 \\
2.6 \\
2.6 \\
2.6 \\
2.6 \\
2.6 \\
2.6 \\
2.9 \\
8.6 \\
6.0 \\
5.4 \\
4.0 \\
3.6 \\
3.6 \\
3.6 \\
.3 .5 \\
3.4\end{array}$ & $\begin{array}{l}3.4 \\
3.4 \\
3.4 \\
3.4 \\
3.4 \\
3.3 \\
3.3 \\
3.3 \\
3.2 \\
3.2 \\
3.1 \\
3.1 \\
3.1 \\
3.1 \\
3.1 \\
3.0 \\
3.0 \\
3.0 \\
3.0 \\
3.0 \\
3.0 \\
2.8 \\
2.7 \\
2.7 \\
2.7 \\
2.7 \\
2.6 \\
2.6 \\
2.6 \\
2.6\end{array}$ & $\begin{array}{l}2.6 \\
3.0 \\
3.6 \\
3.6 \\
3.5 \\
3.5 \\
3.4 \\
3.4 \\
3.3 \\
3.3 \\
3.2 \\
3.2 \\
3.0 \\
3.0 \\
2.8 \\
2.8 \\
2.8 \\
2.8 \\
2.8 \\
2.7 \\
2.7 \\
2.6 \\
2.6 \\
2.6 \\
2.6 \\
2.6 \\
3.0 \\
3.0 \\
3.0 \\
2.8 \\
2.8\end{array}$ \\
\hline
\end{tabular}

$\alpha$ No record May 20 to June 26 , inclusive.

TENNESSEE RIVER AT KNOXVILLE, TENNESSEE.

This station was originally established by the United States Weather Bureau at the old county highway bridge, which has been torn down and replaced by a new bridge. Instead of placing the gage at the new bridge, it was decided to move it down the river, in order to get below some shoals and wing dams which have been put in for boating. A temporary gage was put in at the Knoxville and Augusta Railroad bridge, a half mile below the highway bridge, and was used during the greater part of the year 1899. In the latter part of that year a new permanent gage was established, and readings from it began November 1, 1899. The new gage is located on the right bank 
of the river, just below the mouth of the West Knoxville Bayou and about 1,000 feet below the teimporary gage at the Knoxville and Augusta Railroad bridge. The gage, which is graduated to feet and tenths, is in two sections; the first, a sloping section made of a 2-inch by 4-inch pine timber spiked on top of an 8-inch by 8-inch oak sill well bolted to piles and embedded in crushed stone, reading from -2 feet to 12 feet; the second, a vertical section of standard Weather Bureau pattern, brass scale, screwed to one of the bents of the railroad trestie across the West Knoxville Bayou, about 50 feet from the bank of the river and from the sloping gage, reading from 12 feet to 36.5 feet. The gage is fastened to the upstream post of the bent facing away from the river. The zero of the gage is 804.3 feet above sea level. The bench mark is a cross in the stone on the east corner of the base to the rightbank pier of the Knoxville and Augusta Railroad bridge, and is 806.7 feet above sea level and 2.4 feet above the zero of the gage. The gage was located for the United States Weather Bureau by the United States Engineer Corps. Daily records are kept by the United States Weather Bureau and are furnished to the Geological Survey. Measurements are made at the Cherokee highway bridge 2 miles below the new gage. This bridge is a three-span iron structure and is about 80 feet above low water. The width of the river at low water is 550 feet. The section is a good one, but the current is rather sluggish at low water. During 1900 the following measurements were made by Max Hall:

April 25: Gage height, 4.35 feet; discharge, 17,219 second-fəet.

December 7: Gage height, 5.50 feet; discharge, 23,529 second-feet.

Daily gage height, in feet, of Tennessee River at Knoxville, Tennessee, for 1900.

\begin{tabular}{|c|c|c|c|c|c|c|c|c|c|c|c|c|}
\hline Day. & Jan. & Feb. & Mar. & Apr. & May. & June. & July. & Aug. & Sept. & Oct. & Nov. & Dec. \\
\hline $\begin{array}{r}1 \\
2 \\
3 \\
4 \\
5 \\
6 \\
7 \\
8 \\
9 \\
90 \\
110 \\
11\end{array}$ & $\begin{array}{r}0.7 \\
.5 \\
.4 \\
.2 \\
.8 \\
.8 \\
.9 \\
.9 \\
1.0 \\
.9 \\
1.1 \\
2.4 \\
4.6 \\
4.7 \\
4.3 \\
2.9 \\
2.2 \\
2.0 \\
2.0 \\
2.6 \\
3.1 \\
3.1 \\
2.9 \\
2.5 \\
2.0 \\
2.1 \\
1.8 \\
1.7 \\
1.5 \\
1.4 \\
1.1\end{array}$ & \begin{tabular}{r}
0.8 \\
.7 \\
.8 \\
1.0 \\
1.3 \\
1.6 \\
1.9 \\
1.7 \\
3.0 \\
4.1 \\
4.2 \\
3.7 \\
6.9 \\
1.4 \\
12.7 \\
8.9 \\
7.4 \\
5.6 \\
4.0 \\
3.3 \\
2.9 \\
3.0 \\
3.2 \\
5.0 \\
5.0 \\
4.9 \\
4.8 \\
3.7 \\
\hdashline$\ldots .$. \\
\hdashline$\ldots .$. \\
$\ldots . .$.
\end{tabular} & $\begin{array}{r}3.9 \\
8.4 \\
11.1 \\
9.1 \\
6.1 \\
5.0 \\
4.0 \\
4.9 \\
9.5 \\
10.1 \\
7.9 \\
6.4 \\
5.5 \\
4.7 \\
4.2 \\
4.0 \\
4.6 \\
4.6 \\
4.5 \\
6.0 \\
11.9 \\
13.2 \\
9.4 \\
6.7 \\
5.5 \\
5.7 \\
6.9 \\
6.7 \\
5.8 \\
5.0 \\
4.5\end{array}$ & $\begin{array}{l}4.2 \\
3.9 \\
3.5 \\
3.4 \\
4.5 \\
4.1 \\
3.5 \\
3.2 \\
3.0 \\
2.8 \\
2.7 \\
2.7 \\
2.8 \\
2.9 \\
2.7 \\
2.5 \\
2.3 \\
2.2 \\
3.2 \\
4.7 \\
4.6 \\
5.7 \\
6.4 \\
5.5 \\
4.7 \\
4.0 \\
3.8 \\
3.6 \\
3.2 \\
2.9\end{array}$ & $\begin{array}{l}2.7 \\
2.6 \\
2.4 \\
2.4 \\
2.4 \\
2.3 \\
2.2 \\
2.1 \\
2.0 \\
2.0 \\
2.1 \\
2.1 \\
2.1 \\
1.9 \\
1.8 \\
1.7 \\
1.6 \\
1.5 \\
1.4 \\
1.4 \\
1.4 \\
1.4 \\
1.4 \\
1.3 \\
1.3 \\
1.8 \\
2.0 \\
1.8 \\
1.5 \\
1.3 \\
1.2\end{array}$ & $\begin{array}{l}1.2 \\
1.1 \\
1.1 \\
1.1 \\
1.5 \\
2.4 \\
2.5 \\
1.9 \\
2.2 \\
2.2 \\
1.9 \\
1.8 \\
1.7 \\
2.0 \\
2.0 \\
2.2 \\
4.0 \\
7.8 \\
6.5 \\
5.1 \\
4.3 \\
3.3 \\
2.7 \\
3.3 \\
3.6 \\
4.4 \\
4.2 \\
3.7 \\
3.4 \\
5.8\end{array}$ & $\begin{array}{l}3.8 \\
2.9 \\
2.8 \\
2.8 \\
2.7 \\
.5 \\
2.0 \\
2.0 \\
1.7 \\
1.6 \\
1.4 \\
1.3 \\
1.2 \\
1.3 \\
1.4 \\
1.3 \\
1.3 \\
1.2 \\
1.1 \\
1.0 \\
.9 \\
1.3 \\
1.2 \\
1.5 \\
.1 .5 \\
1.7 \\
5.6 \\
6.0 \\
4.8 \\
4.0 \\
3.5\end{array}$ & $\begin{array}{r}2.7 \\
.2 \\
1.4 \\
1.2 \\
1.2 \\
1.1 \\
1.0 \\
.8 \\
.8 \\
.7 \\
.6 \\
.5 \\
.6 \\
.8 \\
1.4 \\
1.0 \\
.8 \\
.6 \\
.5 \\
.4 \\
.4 \\
1.4 \\
1.5 \\
1.2 \\
1.1 \\
.9 \\
.9 \\
.7 \\
.9\end{array}$ & $\begin{array}{r}1.2 \\
1.2 \\
1.0 \\
.7 \\
.5 \\
.4 \\
.3 \\
.4 \\
.3 \\
.2 \\
.2 \\
.1 \\
.0 \\
.3 \\
.6 \\
1.1 \\
3.3 \\
3.6 \\
2.2 \\
1.4 \\
1.0 \\
1.0 \\
1.0 \\
1.0 \\
1.0 \\
1.0 \\
1.0 \\
.9 \\
.8 \\
.7\end{array}$ & $\begin{array}{l}0.6 \\
.4 \\
.4 \\
.3 \\
.2 \\
.7 \\
.7 \\
.7 \\
.7 \\
.5 \\
.4 \\
.3 \\
.2 \\
.2 \\
.2 \\
.2 \\
.2 \\
.1 \\
.1 \\
.0 \\
4.9 \\
9.4 \\
5.8 \\
4.6 \\
.4 .4 \\
1.8 \\
1.4 \\
1.3\end{array}$ & $\begin{array}{r}1.1 \\
1.0 \\
1.1 \\
1.5 \\
3.6 \\
3.5 \\
2.5 \\
2.1 \\
1.8 \\
1.5 \\
1.3 \\
1.2 \\
1.1 \\
1.0 \\
1.0 \\
.9 \\
.8 \\
.8 \\
.8 \\
.7 \\
.8 \\
.8 \\
.8 \\
.8 \\
.8 \\
5.6 \\
9.6 \\
9.1 \\
5.0 \\
3.6\end{array}$ & $\begin{array}{l}3.0 \\
2.5 \\
2.2 \\
2.6 \\
4.1 \\
6.6 \\
5.9 \\
5.2 \\
3.5 \\
3.0 \\
2.7 \\
2.3 \\
2.0 \\
1.9 \\
1.8 \\
1.7 \\
1.6 \\
1.4 \\
1.3 \\
1.3 \\
1.3 \\
1.8 \\
2.5 \\
2.5 \\
2.3 \\
2.2 \\
2.0 \\
1.9 \\
1.7 \\
1.7 \\
1.8\end{array}$ \\
\hline
\end{tabular}


TENNESSEE RIVER AT CHATTANOOGA, TENNESSEE.

This station was established in 1879, at the foot of Lookout street, just below Chattanooga Island, by the Signal Corps of the United States Army; but since July 1, 1891, it has been in charge of the Weather Bureau. During the year 1900 a new gage was established. It is a vertical timber bolted to the south side of the third stone pier from the south end of the bridge. Gage heights are obtained from L. M. Prindell, United States Weather Bureau observer. Records of measurements made during 1899 will be found in the Twenty-first Annual Report, Part IV, page 168. During 1900 the following measurements were made by Max Hall and others:

March 13: Gage height, 11.25 feet; discharge, 66,012 second-feet.

July 27: Gage height, 3.45 feet; discharge, 18,470 second-feet.

Daily gage height, in feet, of Tennessee River at Chattanooga, Tennessee, for 1900.

\begin{tabular}{|c|c|c|c|c|c|c|c|c|c|c|c|c|}
\hline Day. & Jan. & Feb. & Mar. & Apr. & May. & June. & July. & Aug. & Sept. & Oct. & Nov. & Dec. \\
\hline "30 & $\begin{array}{l}3.05 \\
(a) \\
(a) \\
(a) \\
(a) \\
2.10 \\
2.20 \\
2.30 \\
2.85 \\
2.45 \\
3.35 \\
6.05 \\
8.15 \\
8.70 \\
8.45 \\
7.80 \\
6.35 \\
5.50 \\
5.80 \\
8.50 \\
9.40 \\
8.85 \\
7.95 \\
7.20 \\
6.15 \\
5.50 \\
5.00 \\
4.65 \\
4.20 \\
3.90 \\
3.55\end{array}$ & \begin{tabular}{|}
3.25 \\
2.95 \\
2.60 \\
2.50 \\
2.90 \\
3.50 \\
3.95 \\
3.90 \\
5.35 \\
8.40 \\
9.40 \\
8.95 \\
13.90 \\
2.55 \\
24.00 \\
2.40 \\
17.00 \\
12.05 \\
9.25 \\
7.70 \\
7.10 \\
7.70 \\
8.50 \\
8.55 \\
8.55 \\
9.50 \\
9.30 \\
8.45
\end{tabular} & $\begin{array}{r}8.05 \\
8.70 \\
10.90 \\
12.50 \\
12.75 \\
10.65 \\
110.00 \\
11.65 \\
11.55 \\
16.50 \\
16.15 \\
14.25 \\
11.65 \\
9.85 \\
8.65 \\
8.00 \\
7.80 \\
7.55 \\
7.55 \\
8.55 \\
11.60 \\
14.95 \\
17.40 \\
16.45 \\
11.65 \\
11.15 \\
10.90 \\
10.70 \\
9.35 \\
8.50\end{array}$ & $\begin{array}{r}7.85 \\
7.20 \\
6.85 \\
7.25 \\
8.05 \\
8.55 \\
7.85 \\
7.05 \\
6.50 \\
6.10 \\
6.50 \\
7.50 \\
7.40 \\
7.00 \\
6.50 \\
6.30 \\
8.75 \\
10.65 \\
9.75 \\
9.40 \\
11.70 \\
12.00 \\
11.35 \\
10.70 \\
9.75 \\
8.50 \\
7.80 \\
7.45 \\
7.05 \\
6.60\end{array}$ & $\begin{array}{l}6.20 \\
5.65 \\
5.35 \\
5.15 \\
4.95 \\
4.80 \\
4.65 \\
4.45 \\
4.45 \\
4.35 \\
4.30 \\
4.30 \\
4.15 \\
4.00 \\
3.85 \\
3.75 \\
3.60 \\
3.50 \\
3.40 \\
3.40 \\
3.25 \\
3.15 \\
3.05 \\
3.00 \\
3.15 \\
3.20 \\
3.35 \\
3.60 \\
3.60 \\
3.35 \\
3.05\end{array}$ & $\begin{array}{l}2.85 \\
2.80 \\
3.00 \\
3.20 \\
3.20 \\
3.50 \\
5.65 \\
6.65 \\
6.15 \\
5.30 \\
5.00 \\
4.90 \\
4.50 \\
5.20 \\
5.30 \\
5.25 \\
5.45 \\
6.15 \\
8.85 \\
9.20 \\
8.90 \\
7.65 \\
6.40 \\
6.25 \\
7.15 \\
7.60 \\
8.05 \\
8.20 \\
8.60 \\
8.70\end{array}$ & $\begin{array}{l}8.85 \\
8.15 \\
6.95 \\
6.30 \\
5.80 \\
5.40 \\
5.00 \\
4.50 \\
4.20 \\
4.20 \\
4.30 \\
3.80 \\
3.40 \\
3.30 \\
3.30 \\
3.30 \\
3.20 \\
3.10 \\
3.00 \\
2.90 \\
2.70 \\
2.50 \\
2.50 \\
2.80 \\
3.00 \\
3.10 \\
3.30 \\
4.60 \\
8.00 \\
8.20 \\
7.30\end{array}$ & $\begin{array}{l}6.20 \\
5.40 \\
4.70 \\
4.20 \\
3.00 \\
3.20 \\
2.90 \\
2.60 \\
2.40 \\
2.30 \\
2.10 \\
2.00 \\
1.90 \\
1.90 \\
2.10 \\
2.20 \\
2.30 \\
2.30 \\
2.30 \\
2.20 \\
1.90 \\
1.80 \\
1.70 \\
1.80 \\
1.90 \\
2.50 \\
3.10 \\
2.70 \\
2.50 \\
2.30 \\
2.20\end{array}$ & $\begin{array}{l}2.10 \\
2.00 \\
2.30 \\
2.50 \\
2.30 \\
2.00 \\
1.70 \\
1.60 \\
1.40 \\
1.30 \\
1.20 \\
1.10 \\
1.00 \\
1.10 \\
1.80 \\
3.10 \\
4.00 \\
4.10 \\
4.60 \\
4.70 \\
3.90 \\
3.00 \\
2.60 \\
2.40 \\
2.70 \\
2.70 \\
2.60 \\
2.40 \\
2.30 \\
2.20\end{array}$ & $\begin{array}{l}2.00 \\
1.80 \\
1.70 \\
1.50 \\
1.40 \\
1.30 \\
1.30 \\
1.60 \\
1.80 \\
2.10 \\
2.10 \\
2.50 \\
3.00 \\
2.50 \\
1.90 \\
1.80 \\
1.60 \\
1.50 \\
1.40 \\
1.30 \\
1.20 \\
1.20 \\
1.40 \\
2.20 \\
4.10 \\
7.00 \\
7.50 \\
6.00 \\
4.90 \\
3.70 \\
3.40\end{array}$ & $\begin{array}{c}2.90 \\
2.60 \\
2.50 \\
2.90 \\
3.30 \\
3.70 \\
4.20 \\
4.20 \\
3.70 \\
3.20 \\
3.00 \\
2.70 \\
2.50 \\
2.30 \\
2.20 \\
2.10 \\
2.00 \\
2.00 \\
1.90 \\
1.90 \\
2.10 \\
2.20 \\
2.30 \\
2.80 \\
3.20 \\
7.80 \\
13.90 \\
15.60 \\
15.60 \\
13.20\end{array}$ & $\begin{array}{l}8.70 \\
6.50 \\
5.60 \\
5.10 \\
5.60 \\
6.90 \\
8.30 \\
9.20 \\
8.50 \\
7.00 \\
6.10 \\
5.40 \\
4.90 \\
4.50 \\
4.30 \\
4.20 \\
4.00 \\
3.60 \\
3.40 \\
3.30 \\
3.30 \\
4.00 \\
4.20 \\
4.70 \\
5.20 \\
5.40 \\
5.20 \\
4.60 \\
4.30 \\
4.20 \\
4.50\end{array}$ \\
\hline
\end{tabular}

$a$ Frozen.

[Continued in Water-Supply Paper No. 49, where will be found numerous miscellaneous measurements of streams in the southern Appalachian region.] 
